

\title{
THE ADAPTIVE REUSE OF WAREHOUSE AND FACTORY BUILDINGS INTO RESIDENTIAL LIVING SPACES IN WELLINGTON NEW ZEALAND
}

How did the warehouse conversion movement evolve in Wellington and through which architectural approaches, criteria and methods may we examine the success of a warehouse and factory conversion project?

\author{
Anya Kouzminova
}

A thesis submitted in partial fulfilment of the requirements for the Degree of Master of Architecture

at

Victoria University of Wellington 


\section{CONTENTS}

$\underline{07}$

Abstract

$\underline{08}$

Methodology and thesis summary

This section discusses the methods and approaches taken to collect the data and establishes which key themes were discussed and how they influenced the research.

$10 \quad$ Introduction

This section introduces the research question. and the key themes and ideas analysed in the thesis.

$\underline{14}$

SoHo: Pioneer of the Warehouse Living Movement

This section looks at the precedent of loft living and discusses how it ultimately helped spread the loft living movement globally. It also looks at the evolution of the loft living movement in New York culturally, politically, economically and architecturally.

$\underline{30}$ Introduction to Wellington Case Studies

This section introduces the Case Studies analysed in the following Chapters, and how they were selected. It also looks at the evolution of the warehouse conversion movement in Wellington, New Zealand.

$3501:$ Case Study One: Shed 21, Waterloo on Quay Apartments, 28 Waterloo Quay, Wellington

54 02 Case Study Two: Odlin's C \& A Timber and Hardware Building, 11 Cable Street, Wellington

70 03 . Case study Three: Hannah Factory, 14 Leeds Street, Te Aro

$86 \quad 04:$ Hannah Warehouse 13 Leeds Street

$100 \quad$ Comparison and Discussion

Compares the different approaches and methods in all four Wellington conversion examples as well as comparing the evolution of the loft living movement and conversion processes of Wellington to those in New York.

$\underline{108}$ Recommendations for Future Conversions

A summation of successful methods and approaches obtained through the analysis of the four Wellington case studies and resulting recommendations of methods and strategies to implement in future conversions of warehouse and factory buildings.

111

Conclusion

114 Bibliography

$\underline{120}$ Figures 


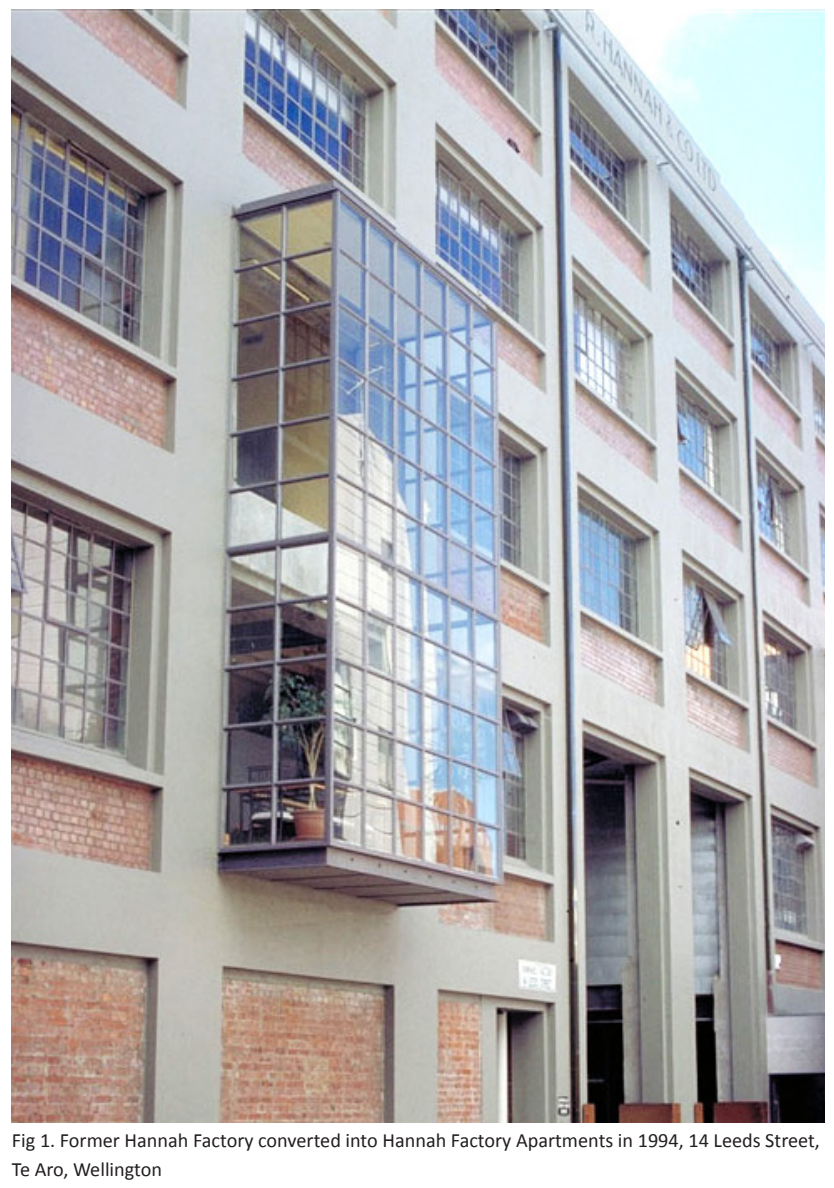




\begin{abstract}
Adaptive reuse does not only mean successfully putting new uses into an old shell. At best the impression is given that a building at the moment of its conversion has finally achieved its true destiny. ${ }^{1}$

Constructed during the industrial era, often utilitarian and non-descript in their design, warehouse and factory buildings were constructed to store and manufacture goods. Upon their obsolescence, due to containerisation, the closure of business, and subsequent dereliction through disrepair or disuse, these largely structurally sound buildings were left vacant until a cultural movement began in America, converting them into living and studio spaces. The adaptive reuse of these buildings resulted in a new programme, which was to provide residence and 'store' people. Much later, in the 1990s this movement spread to Wellington, New Zealand. This delay raises the issue of what makes a successful conversion of a warehouse or factory building to loft-style living space, and through which architectural approaches, criteria and methods may we examine these buildings?
\end{abstract}

This thesis first examines pioneering examples of loft and warehouse living in SoHo, New York, from the initial subversive beginnings of the movement, when artists illegally occupied these spaces. It looks at the gentrification of neighbourhoods and how the loft eventually emerged as a highly sought after architectural living space, first in SoHo, New York before spreading globally to Wellington, New Zealand. Four Wellington warehouse and factory buildings that were converted into residential living spaces are examined and compared. The aim is to understand the conversion process and necessary strategies required to instil a new architectural programme within an existing warehouse or factory building, recognising the unique conditions in such converted architectural spaces.

A reused, converted warehouse or former factory can acquire characteristics unique to that building: a certain patina of age, a residue of industrial history, imbedded qualities of surface, a unique architectural structure, as well as the location of the building itself. The case studies show how these imbedded characteristics, can be preserved when the building is converted, thereby retaining the building's former history while providing a new function.

This thesis then analyses whether any commonalities and differences in warehouse and factory living existed between Wellington and SoHo New York, in terms of the evolution of the cultural movement and architectural design.

The thesis shows that successful approaches to conversion of factories or warehouses can both save the buildings from demolition, preserve and highlight their heritage and create an architecturally unique space, with inherent qualities that cannot be recreated in a new building. Thus, only upon conversion, can the building gain a sense that it has achieved its true destiny.

$1 \quad$ Frank,P. J., Old \& New : design manual for revitalizing existing buildings. 130 


\section{Methodology and Thesis Summary}

The diagram below introduces the three main phases and key themes of the research undertaken for this thesis. The objective of the thesis was to analyse the evolution of the loft living movement in Wellington, New Zealand by looking at SoHo as the main source for comparison and other key external influences including the changing cultural, political, economic and architectural factors. Four Wellington case studies of converted warehouse and factory apartment buildings were chosen for analysis and assessment. Their analysis formed a catalogue of relationships between the conditions surrounding the existing buildings and the new elements required for their adaptive reuse.

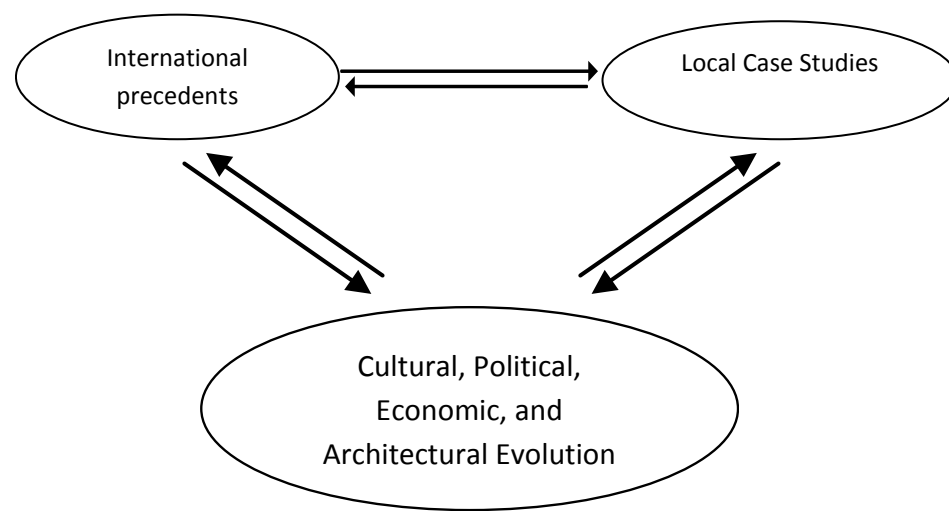

Fig 2. Research Phases and key themes

The SoHo district of, New York was used as the main international precedent of the warehouse conversion movement because it was one of the earliest recorded pioneering events in loft living. This SoHo movement was then used as a means of comparison for the evolution of the warehouse living phenomenon in Wellington, New Zealand.

As the research progressed, it became evident that a set of common factors and intervention methods were required for the conversion of factory and warehouse buildings into apartments, both in SoHo and Wellington. A vocabulary pertaining to what would identify a converted warehouse apartment was established. As well as analysing the macro conditions, including the cultural, political and economic backgrounds, the evolution of the architectural style and design characteristics that represented converted warehouse and factory apartments were also examined and compared both internationally and with and between the four local Wellington case studies.
The gentrification process that occurred in SoHo through the conversion of redundant warehouses and factories, was analysed in the SoHo Chapter, to understand how and why the process of converting derelict buildings spread internationally. Changes in the demographic of residents, and how it evolved from the original illegally squatting artists paying a minimal amount of money, to the higher earning professionals and even later families, acquiring these highly sought after properties for maximum financial outlay, was also determined. The impact on the neighbourhood through the reuse of these buildings was analysed and compared to determine whether any similarities in urban gentrification existed with the warehouse living movement in Wellington, New Zealand.

To understand which methods were used and how each conversion in Wellington varied amongst the four local case study converted warehouse or factory apartments, a set of characteristics was devised which would be evaluated for all four buildings. These included: the history and conditions of the existing building, year of original construction and year of conversion, intended demographic, historic importance, size and layout, design approaches and aesthetic, structural upgrade, fire protection, kitchen and bathroom design, furniture, and car parking. In addition, comparison was made with the characteristics of the loft living movement in SoHo, New York.

In analysing each of the local case studies against this set of criteria, certain strategies that were used to retain as much of the building's original character, (and therefore retain traces of its former uses), became evident in each conversion study. The success of the aesthetic and general design in the conversion was based upon its similarity to the precedent lofts analysed in the SoHo precedent study.

When evaluating the Wellington examples, the earliest recorded examples of converted warehouses and factories were used as the model of comparison. The information on the loft-living movement in SoHo, New York was gathered from books, journals, email correspondence with The City of New York, interviews, newspaper articles, photographs, databases and the internet.

The Wellington case studies were selected based on their varied locations and the years they were converted. The Hannah Factory was found to be the earliest recorded example of a converted factory in Wellington. The inner city Hannah Factory and Hannah Warehouse conversions were chosen because of their association with manufacturing and storage uses, whilst the waterfront located Shed 21 and Odlin's Building differed due to their connections with the waterfront industries. Each of the four example buildings 
also became obsolete for different reasons and at different times, due to external conditions happening nationally and worldwide, such as containerization and the economic state of the country at the time.

Information regarding the Wellington warehouse conversion phenomenon was collected through some of the following methods: personal interviews with architects (including Athfield Architects and John Gray), current and former residents, property developers, academics, engineers, and residents of Wellington city; on-line interviews and email correspondence; books, journals, magazines, news paper articles, trade publications, recorded conferences and talks, and archive material such as letters. Institutions consulted included The New Zealand Building Code, Wellington City Council, Wellington Waterfront Framework, New Zealand Archives, New Zealand Historic Places Trust, and Wellington City Archives. In addition site visit were undertaken and digital models of two of the case study buildings created, based on written documentation for the buildings, plans and photographs. The Victoria University of Wellington Ethics Approval was obtained to carry out structured interviews with numerous parties and sources of reference.

Two Wellington case study buildings were digitally modelled and rendered to better understand and show how these buildings were structurally upgraded and strengthened and the architectural changes that occurred upon conversion. This in turn helped in understanding how these buildings would stand up in an earthquake today, and meet the Building Code regulations and the development in strengthening methods that have occurred since the building's upgrade. 


\section{Introduction}

The Adaptive Reuse of Warehouse and Factory Buildings into Residential Living Spaces in Wellington, New Zealand

How did the warehouse conversion movement evolve in Wellington and through which architectural approaches, criteria and methods may we examine the success of a warehouse and factory conversion project?

\begin{abstract}
Probably the most significant aspect of the domestication of the Industrial aesthetic is time...Like Gothic ruins in the 19th Century, artifacts of the Industrial Age now inspire nostalgia for the past. ${ }^{1}$
\end{abstract}

This thesis examines the subject of adaptively reusing warehouse and factory buildings by converting them into residential living spaces, thus ultimately preserving historic architecture without resorting to demolishing the existing structure. It investigates whether a building that was initially designed to suit a specific programme (storage) can be successfully re-adapted to serve an entirely different one; primarily that of providing residential space for people. By analysing four Wellington case studies of such converted warehouse and factory buildings to apartments, the thesis proposes a set of criteria and requirements necessary for a successful conversion into residential spaces. This thesis also looks at what kind of atmosphere, aesthetics and quality is instilled in such buildings, and whether their industrial past creates a distinct environment, pertaining to their historic past, remaining, even after the conversion and change of use occurs.

This thesis examines the earliest recorded loft living origins, which occurred in SoHo, New York, assessing this cultural movement from the pioneering artist residents to its eventual spread to the wider public. It looks at the architectural trends associated with the conversions, and determines whether any parallels exist, both architectural and social, between Wellington conversions and those of SoHo, New York. It will look into the history of the loft living cultural phenomenon, and what led to its global spread, whilst analyzing the successful architectural, structural and design approaches that are required to carry out such conversions.

A warehouse is defined by the Oxford English Dictionary as,

A building or part of a building used for the storage of merchandise; the building in which a wholesale dealer keeps his stock of goods for sale; a building in which furniture or other property is housed, a charge being made for

1 Harbison, Robert. Eccentric Spaces.73 the accommodation; a government building (more fully bonded adj. warehouse) in which dutiable imported goods are kept in bond until it is convenient to the importer to pay the duty. ${ }^{2}$

And a factory,

$$
\begin{aligned}
& \text { A building or range of buildings with plant for } \\
& \text { the manufacture of goods; a manufactory, } \\
& \text { workshop; 'works'.3 }
\end{aligned}
$$

Thus, warehouses and factories were originally built to serve a distinct function; the storage of goods and merchandise and for manufacturing. Upon conversion into residential dwellings, these buildings' uses essentially shift to 'storing' people as opposed to merchandise.

In order to understand how the loft living phenomenon originated it is important to understand why the obsolescence of warehouse and factories occurred in the first instance on a global scale.

After World War II, ships became larger, requiring deeper ports. This resulted in the development of container ports, which required not only larger harbours but acres of land for container storage in place of the original port side warehouses. ${ }^{4}$ The introduction of containers for storage was termed 'containerization'. ${ }^{5}$ The warehouses thus became derelict, no longer fit for their intended purposes. In the area of Manhattan, during the early 1940s, former warehouse and factory buildings began to close in the face of declining sales and changing industrial practices at home and abroad and fell into disrepair as a result. These buildings no longer had the fashionable allure of uptown nor the working dimensions or reassuring collegiate appeal of the burgeoning skyscrapers of Wall Street. These former industrial buildings were however cheap and architecturally sound. ${ }^{6}$

In the late $1950 s^{7}$, the eventual reuse of warehouses and factories into residential dwellings came to represent a major trend in urban redevelopment in the last 30 years. ${ }^{8}$ Instead of building from scratch, loft dwellers and developers thus expressed a respect for the urban past through preservation. In a sense these structures that once stored 'goods', were readapted to 'store' people, through the provision of shelter and living space.

Carol Berens, author of Redeveloping industrial sites

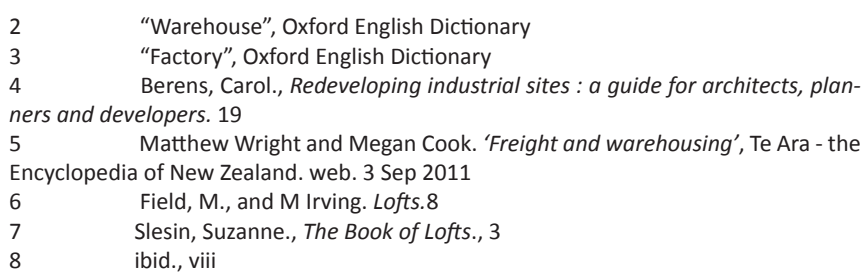


described the demise of these buildings,

Industry's exodus has dealt a severe blow to
urban areas, now empty shells of their former
selves, pockmarked with vacant, deteriorating
buildings, victims of the transformation of
the labor force and changing methods of
distribution of goods. Left in their wake were
rotting piers, abandoned factories and empty
collapsing warehouses, often near city centres.

These buildings were left deserted and obsolete as they were no longer fit to serve their existing purpose. Left to their demise, they stood waiting re-adaptation, rejuvenation and the implementation of a new programme. In the early 1960s, the warehouse loft-living movement originated in New York's SoHo district. Bordered by Canal Street, Broadway, Howard, Crosby, East and West Houston and West Broadway, the SoHo Historic District was, architecturally, the most unified area in New York, containing the largest remaining group of cast-iron structures in the world to this day. ${ }^{10}$ Artists found these spaces ideal both to work and live in. The rent was cheap and the structural proportions with high ceilings and ample light were ideal for creating artworks. The origins of loft living were humble, and often little more than an illegal squat. $^{11}$

Carol Berens introduced this revolutionary way of implementing residential dwelling into warehouses.

\begin{abstract}
During the late 1950s and 1960s these warehouses were colonized by artists attracted to the lofts in cast iron buildings that had raw, unfinished open interior spaces conducive to creating large scale art work that was a hallmark of contemporary art and, of course cheap rent. During the 1960 s artists upgraded these lofts through sweat equity creating illegal live in studios camping out in former apparel and metal shops and warehouses...a small community formed when these urban artists moved in as manufacturers moved out. ${ }^{12}$
\end{abstract}

These artists were the pioneers of the warehouse living lifestyle. This occurred at a time when the ideal of suburban living was at its height and the notion of living in a warehouse space was unheard of and incomprehensible to most people. Until the 1970s, living in a former warehouse space was considered neither chic nor comfortable, if a possibility at all. ${ }^{13}$

Sharon Zukin in her book, Loft Living, talks about the public's $9 \quad$ Berens, C. Redeveloping industrial sites: a guide for architects, planners and developers.19

$10 \quad$ Homberger, E. New York City: a cultural and literary companion. 197

11 Field, M., and M Irving. Lofts. 4

12 Berens, C. Redeveloping industrial sites : a guide for architects, planners and developers.76

$13 \quad$ Zukin, S. Loft Living.58 initial hesitation toward living in a warehouse at the early beginnings of this movement,

making a home in a factory district clearly contradicted the dominant middle class ideas of "home" and "factory" as well as the separate environments of family and work on which these ideas were based. ${ }^{14}$

The infiltration of artists into these spaces initiated a new way of living, one that made living in a former warehouse space acceptable and even ideal. This was evident when loft living was legalized due to public petition ${ }^{15}$. As a result rent went up as more interest in loft living developed. A middle and upper class demographic started to move in, and the artists inevitably moved out. Improvements were made to the properties and market prices and tax assessment rose. ${ }^{16}$ Jesus Pedro Lorent refers to this process as gentrification, described in his paper, Art Neighborhoods, Ports of Vitality,

...redundant buildings with stagnating rents in a deprived area get resuscitated thanks to the presence of artists, this attracts developers who transform the district into an 'artist quarter', which brings in a lot of people, institutions and money but, eventually will inevitably expel the artists. $^{17}$

Berens also states that,

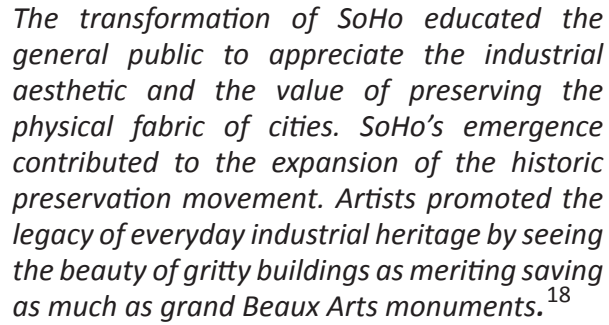

Sharon Zukin talks about the artist as a gentrifier of these industrial areas, by being those who inevitably influenced the wider community to the point where warehouse living became a socially acceptable lifestyle,

On the one hand, loft living began as a 'marginal' phenomenon, but in time it became chic. On the other hand, artists who moved into lofts were 'powerless', yet they managed to win access to contested urban space. ${ }^{19}$

This thesis will analyse the early beginnings of loft living

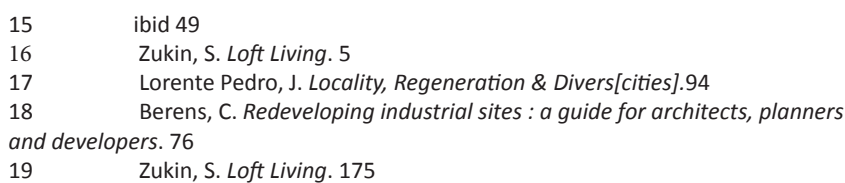


and how the movement spread to create a property market, with the general public finding this living mode desirable. Ultimately it will assess what it was that drew the public to inhabit these alternative living spaces. It will examine and compare the renovations of the early pioneering artist lofts in New York, to their eventual modernization and modifications in the early nineties and more recently, whilst also comparing the four selected conversions of Wellington warehouses and a factory to apartments to determine the parallels and differences.

The four chosen conversions are examined based on the necessary structural and legal requirements obligatory to allow legal residential living. The four Wellington case are also analyzed based on architectural decisions, the social and historic nature of the buildings, their historic registration and whether this played a significant role in the eventual outcome of the overall conversion, as well as the different design approaches, aesthetics and atmosphere, instilled within each conversion.

The success of the individual case studies reuse was also determined based upon how much of the original former building's existing nature was retained, through architectural decisions, reuse of existing fabric and material, and whether new modifications were done with consideration and respect for the existing building.

Other outcomes of conversions are examined, including those that cannot be easily measured in terms of materials or physical structure. The atmosphere and mood, as well as the patina of age and history are immeasurable, yet present in the atmosphere of the converted building. Marcus Field and Mark Irving in their book Lofts, referred to warehouse buildings as being more than mere shells formerly used to store manufactured goods and stock. They state there is a longing to preserve their essence and carry on their legacy through reusing them.

\begin{abstract}
The romantic associations of the loft building are now manifold as the early loft dwellers' idealization of the industrial past becomes layered with a new generations idealization of the bohemian lifestyle of the 60's and 70 's. ${ }^{20}$
\end{abstract}

Reinhard Kropf of the Norwegian Practice, Helen \& Hard states that,

Often converting spaces provides architects with the chance to develop a sensibility for the sometimes forgotten qualities of atmospheric complexity, vernacular expression and operational pragmatism. $^{21}$

\begin{tabular}{ll}
\hline 20 & Field, M., and M Irving. Lofts. 47 \\
21 & Dean, C., and E O'Kelly. Conversions. 17
\end{tabular}

Zukin reiterates this notion of the urge to live in an industrial space as a wanting to reconnect with human past,

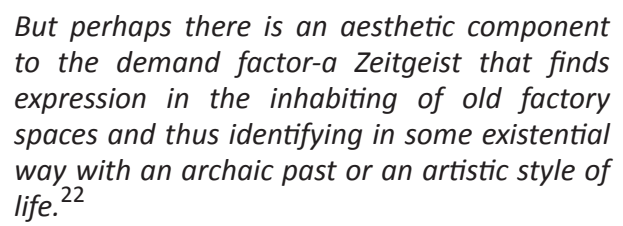

This thesis attempts to understand what the unique characteristics this type of converted building and thereby style of living it possesses. It also analyzes the evolution of the loft living movement and determine how much of the authentic raw conversion was present in recent examples, both locally and abroad. The loft living movement which started out as a cultural and social movement has, for the greater part, become a popular trend, that has been generalized and used to market apartments rarely possessing the true distinct qualities of a loft space. It is however, interesting to determine how the loft living term was coined and why having an association with this type of place became so sought after.

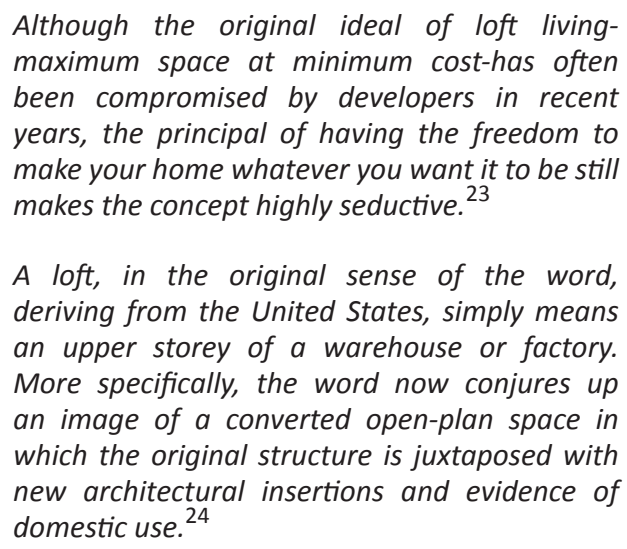
maximum space at minimum cost-has often been compromised by developers in recent years, the principal of having the freedom to make your home whatever you want it to be still makes the concept highly seductive. ${ }^{23}$ deriving from the United States, simply means an upper storey of a warehouse or factory. More specifically, the word now conjures up an image of a converted open-plan space in which the original structure is juxtaposed with new architectural insertions and evidence of domestic use. ${ }^{24}$

This thesis examines whether re-adapting a building is beneficial, both in a social and urban sense, in terms of historic preservation, reuse of existing structure and ultimately avoiding demolition by adapting the building for new use. It looks into the demise of warehouse and factory buildings, their obsolescence and eventual reuse and adaptation. It proposes an analysis and from that a set of criteria for the conversion of factory and warehouses into residential living spaces. An understanding of and reasoning of why a a particular approach was taken will be established. Examples of conversions abroad are compared to local projects in Wellington, New Zealand identifying similarities an differences both in the conversion processes as well as comparing the evolution of the warehouse living movement locally and abroad.

$\begin{array}{ll}22 & \text { Zukin, S. Loft Living. 14 } \\ 23 & \text { Field, M., and M Irving. Lofts. } 5 \\ 24 & \text { Field, M., and M Irving. Lofts. } 137\end{array}$




\section{SoHo: Pioneer of the Warehouse Living Movement}

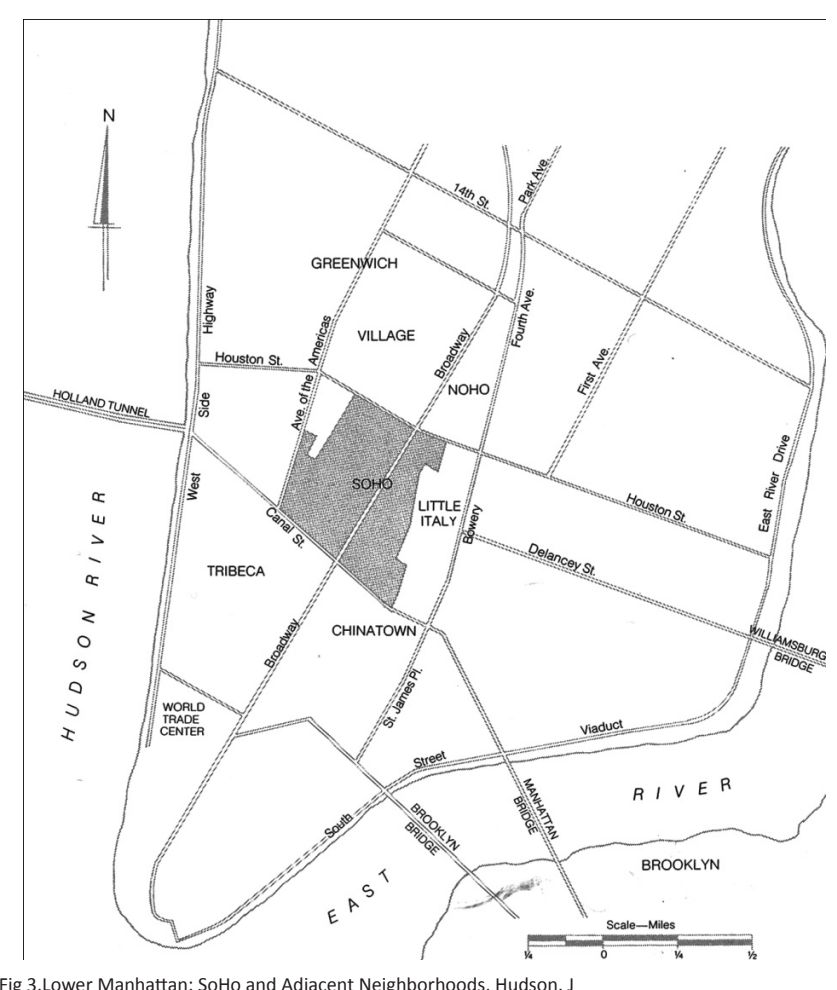

Fig 3.Lower Manhattan: SoHo and Adjacent Neighborhoods, Hudson. J

\section{$\underline{\text { Introduction }}$}

This chapter will discuss the pioneering loft movement that occurred in SoHo New York, most prominently during the late 1950 s and 1960s. After the decline of many manufacturing businesses, former industrial warehouses and factory buildings were left obsolete and vacant. Artists saw potential in these buildings for both working and living, due to their double height spaces, abundance of light and cheap rent. This chapter will also discuss how loft living soon became a phenomenon resulting in a trend that made living in converted warehouse or factory spaces desirable.

\section{Obsolescence and Rejuvenation}

The earliest recorded conversion of warehouses and factories into residential buildings was first witnessed in New York's SoHo region, an acronym for South of Houston (Houston being Houston Street). It comprised the 43 block area in Manhattan situated between Houston and Canal Streets and is where the movement was forged.

The decline and abandonment of warehouses was due to advancement in storage methods on the wharfs and decline in manufacturing. Manufacturers were converting to containerisation as a means of storing imported and wholesale goods. They were seeking bigger buildings and moving away from the original wharfs and inner city sites to the metropolitan outskirts. This inevitably resulted in existing buildings losing their raison d'être. Carol Berens, author of Redeveloping Industrial Sites: a guide for architects, planners and developers, described the isolation and state that these now obsolete buildings were left in when the conversion to containerization and decline in manufacturing occurred,

\begin{abstract}
As a result of changes in manufacturing and transportation spurred by World War II, ships became larger, requiring deeper ports. More efficient methods to increase cargo capacity and prevent theft at the docks hastened the need for container ports, which required not only larger harbours but acres of land rather than mere port side warehouses. ${ }^{1}$
\end{abstract}

The location of warehouses was selected based upon their close proximity and convenient access to rivers and oceans, being ideal for trading purposes. ${ }^{2}$ They were ideally situated for the unloading and storage of merchandise and goods which were discharged directly off ships. As goods came in from the ships, they were stored, protected from the weather and kept secured 'in bond' until the payment of customs duty by the importer. Warehouses were thought of as being stores where goods were kept prior to dispatch to shops or sales outlets; or acted as chambers for the exhibition of goods for sale directly to a wholesaler. ${ }^{3}$

\section{Location}

The area of SoHo was heavily inundated with warehouse buildings. Prior to becoming a warehousing and industrial area, it was once populated by the middle class, who eventually followed the upper classes downtown to Fifth Avenue in $1850 .{ }^{4}$ Prior to becoming an industrial area, SoHo was known for being the centre of retail. There are only a few reminders of that retailing majesty, like the old Lord \& Taylor Building Fig 5 at the corner of Broadway and Grand, and the cast-iron Haughwout Building Fig 4 one block north at the intersection with Broome Street. Many of the cast iron structures were prefabricated nearby at James Bogardus' factory below Canal Street. ${ }^{5}$ The SoHo Historic District has remained architecturally, the most unified area in New York. It contained the largest concentration of cast-iron structures. ${ }^{6}$ The use of cast iron was ideal for factories and warehouses because moulds were cheap and required less skilled labour to make as opposed to cut stone, thereby, builders were able to decorate what were quite utilitarian structures with a 1 Berens, C., Redeveloping industrial sites : a guide for architects, planners and developers. 19

2 ibid 3

3 Pragnell, H. J., Industrial Britain : an architectural history. 113 Manhattan 21 Hudson, R.J., The Unanticipated City-Loft Conversions in Lower

$5 \quad$ Homberger, E., New York City: a cultural and literary companion. 197 6 Garvin, A., The American city: what works, what doesn't. 490 
richness of design. ${ }^{7}$ However the quality of the iron designs was not sacrificed despite their ability to be assembled so quickly. Architects found the relatively inexpensive cast iron could form the most intricately designed patterns, and because stone was the material associated with architectural masterpieces, cast iron, painted in neutral tints such as beige, was used to simulate stone. Builders were able to decorate utilitarian structures with richness of design. A unique construction innovation for their time, cast iron columns had the advantage of being slender when compared to masonry columns capable of supporting similar weight, thus saving space in warehouses and factory buildings. There remain 50 such buildings on Greene Street alone.

In 1879, SoHo saw a period of warehouse construction, providing spaces for maritime and manufacturing businesses. They were generally five to six storeys high, with wide unobstructed floors, and large open windows that illuminated the space within. James Hudson states in his book, The Unanticipated City-Loft Conversions in Lower Manhattan, "one was supposed to walk West Broadway to see the beauty of the Renaissance, rewired in modern iron." ${ }^{8}$ At the height of the Industrial Revolution, when the manufacturing business was at its apex it was fitting that these buildings were infiltrating large cities, as business boomed and trade was at its pinnacle. This technological advancement however, was the primary factor that drove people out of the city. The noise and pollution and the expansion of roads served to disperse the population out into the outskirts and suburbs, leaving the city as a place solely designated to work and thus emptying the city. It was at this time that in America, government policies encouraged the building of suburbs, resulting in people moving there and leaving the city abandoned, to become an industrial wasteland full of events in the daytime yet deserted at night. Suburbia was born as the city was emptied out of people, left purely as a work zone.

SoHo and other areas of Manhattan continued to enjoy economic prosperity as centres of manufacturing, but by the 1920s, with a small reprise caused by mobilisation during World War II, SoHo declined significantly as a viable commercial zone. ${ }^{9}$ Technological change and advancement was inevitable, particularly in the climate of the economic expansion of the 1960s. Traditional manufacturing industries, the railways, docks and markets were being made redundant. Buildings became obsolete and their replacement was necessary in the interests of efficiency and modernisation. The warehouse industry was affected and these buildings soon lost their value. Manufacturers were lured away to the fringes of the city by custom built factories offering more $7 \quad$ Homberger, E., New York City: a cultural and literary companion.197 8 Hudson, R.J., The Unanticipated City-Loft Conversions in Lower Manhattan.22

9 Hudson, R. J, The Unanticipated City-Loft Conversions in Lower Manhattan.23

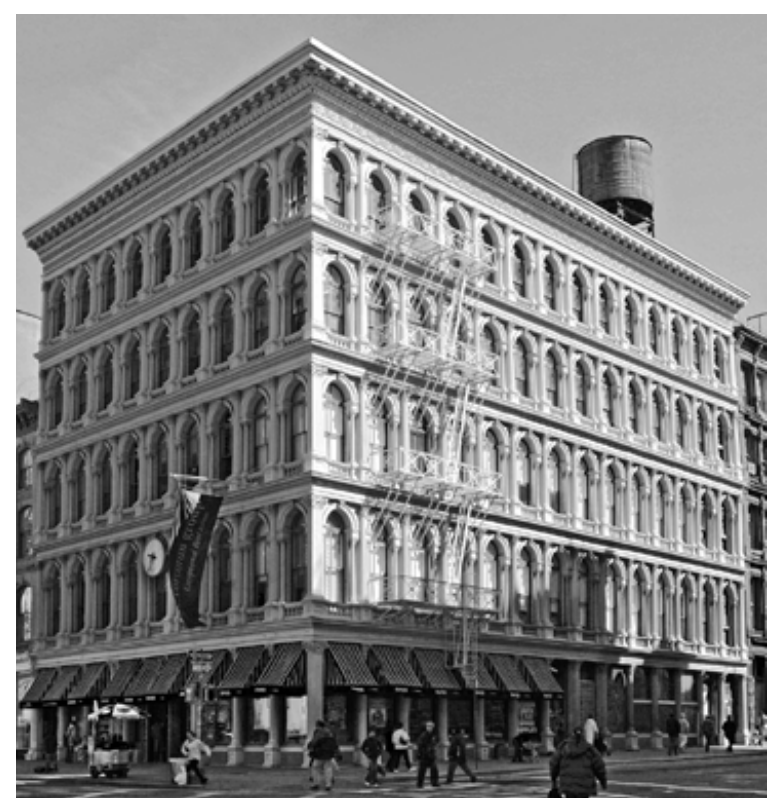

Fig 4. Haughwout Building, Williams. J. example of a cast iron adorned building.

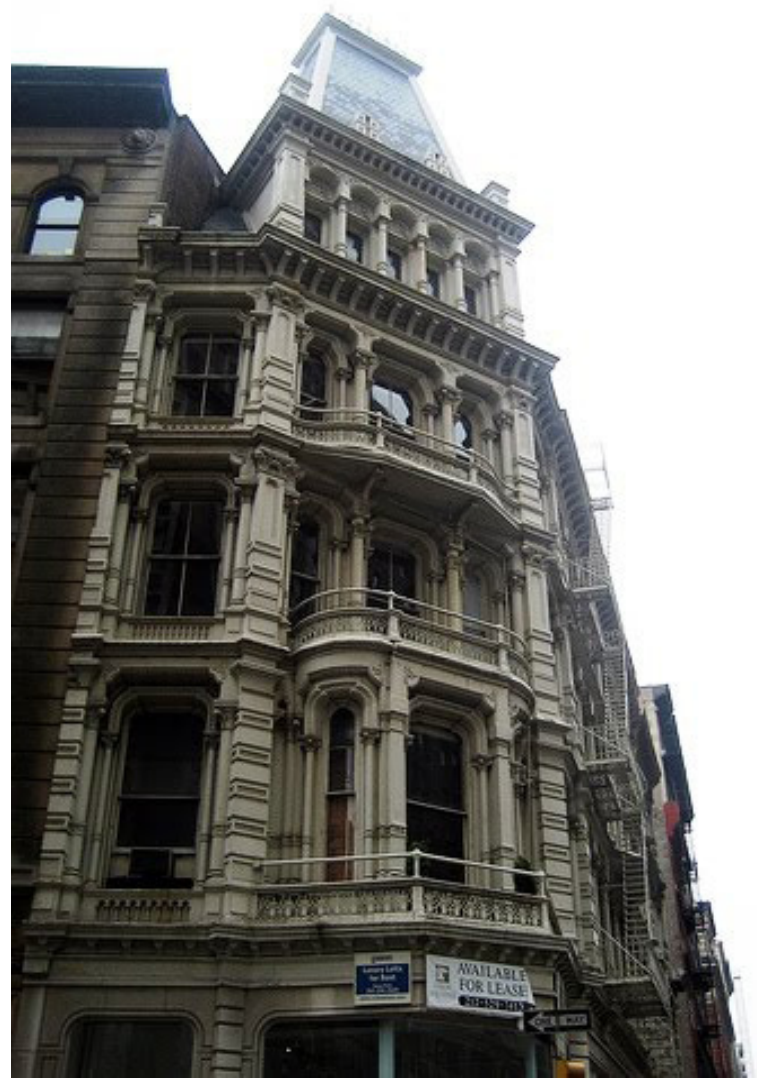

Fig 5. Lord Taylor Building, another example of a former retail building.

space and improved road access. Landlords had no choice but to rent out the large warehouses to small businesses and shops, yet as conditions changed again, warehouses were 
further vacated, yet again lowering the occupancy levels.

\section{Architecture and Design}

SoHo's five and six storey loft structures, erected during the second half of the nineteenth century had broad windows for display of merchandise, middle floors for office work, and upper floors for storage. They were unique because of their self supporting front walls and interior columns of prefabricated cast-iron pieces. There was plenty of light provided by the large expanses of window glass, again supported by cast-iron columns as opposed to masonry walls. ${ }^{10}$

The proportions of these loft structures were generous. Usually they would have 10,000 square feet $\left(100 \mathrm{~m}^{2}\right)$ of space on each of two or three floors. Ceilings were 12 to 15 feethigh (3.6- 4.6 metres) supported by either vaulted arches (in smaller buildings) or columns. Architectural detail was often classical, reflecting a late nineteenth century taste for Italian Renaissance. Columns in loft buildings were frequently fluted, and the building facades were generally cast iron. ${ }^{11}$ In contrast to the construction materials used in modern buildings, those used in loft buildings were more solid (brick and iron) and more valuable (often oak flooring and even copper windowsills). ${ }^{12}$

Loft living has played an important role in
"domesticating" the industrial aesthetic.
The factory origins and the present mixed
use of many lofts suggest, in the interest of
authenticity, the adoption of an industrial
style...the exaggerated scale of a loft provides
a natural setting for the new cult of domesticity
that worships restaurant and supermarket
equipment, industrial carpeting, and Pirelli
rubber tiles. ${ }^{13}$

Valuing economics over aesthetics, many of the structural features within the building were left exposed. Columns and piers interrupted and gridded the space, supporting ceiling beams and vaults. Ventilation duct work and electrical conduit would weave back and forth across the ceilings, while plumbing and heating pipes tended to run up and down the corners and along the bottom of walls. These features were again left exposed for practical reasons. Covering them up could have resulted in lower ceilings. With the skeleton of the building left on view, a maximum amount of space was visible and available for reuse. ${ }^{14}$

To stand up to the abuse of working factories, lofts were originally constructed of the hardiest

\footnotetext{
10 Garvin, A., The American city: what works, what doesn't. 490

11 Zukin, S., Loft living : culture and capital in urban change. 9

12 Field, M., and M Irving. Lofts.5

13 Zukin, S., Loft living : culture and capital in urban change. 68

14 Tolliver, J., Loft style. 10
}

materials available. Hence, walls are usually composed of exposed brick, support columns tend to be made of concrete, and floors consist of either concrete or wood planking. Metal and rubber also figure prominently: the former appears as cast-iron plumbing pipes, aluminium window muntins, and industrial size steel bolts on support beams... while rubber often manifests itself in electrical wiring and sometimes flooring. ${ }^{15}$

These derelict warehouses thus became ideal candidates for conversion and adaptive reuse, as they were innovative in terms of architecture for their use of cast iron and masonry, providing strong structural frameworks and an open floor space that could be easily adapted to house a new programme. They were also among the best candidates for conversion into dwellings, given the virtual impossibility of finding more recently constructed spaces that offered the same dimensions and open layouts. A new opportunity arose to create something innovative in these decrepit buildings. The irony in the change from an industrial to a residential use was that these buildings that once housed 200 workers in an oppressive working environment now had the possibility of becoming a dwelling to a single occupant, or a family at most.

Owners of buildings who happily rented out their spaces to artists did not look too closely at their tenants. Nor did they or their tenants care whether renovation was consistent with the building's historic character or its context within the historic district. Because these buildings were not legally zoned for residency, altering them proved costly. As a result lofts were altered without legal permission. Living in a warehouse space allowed the inhabitant to have a space that was completely individual, devoid of any preconceived style or the uniformity of the social idea of what a house should be.

The appeal of SoHo was the availability of large spaces at very low rents. The strong structural bearing capacities and standard $12(3.6 \mathrm{~m})$ high ceilings and 2,000 square feet $\left(200 \mathrm{~m}^{2}\right)$ of floor space meant artists could create large art works and also permitted experiments on a grand scale. Large sculptures could be undertaken on the upper floors, which could be easily reached by the large freight elevators inside the buildings. ${ }^{16}$

Most lofts in SoHo had no heat or running water, and very few electric sockets. One SoHo artist used to bathe in his friend's apartment, and the loft described below was rented for ten dollars a month to a penniless artist.

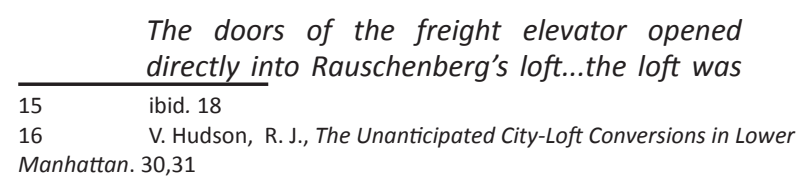

The doors of the freight elevator opened ibid. 18 Manhattan. 30,31 


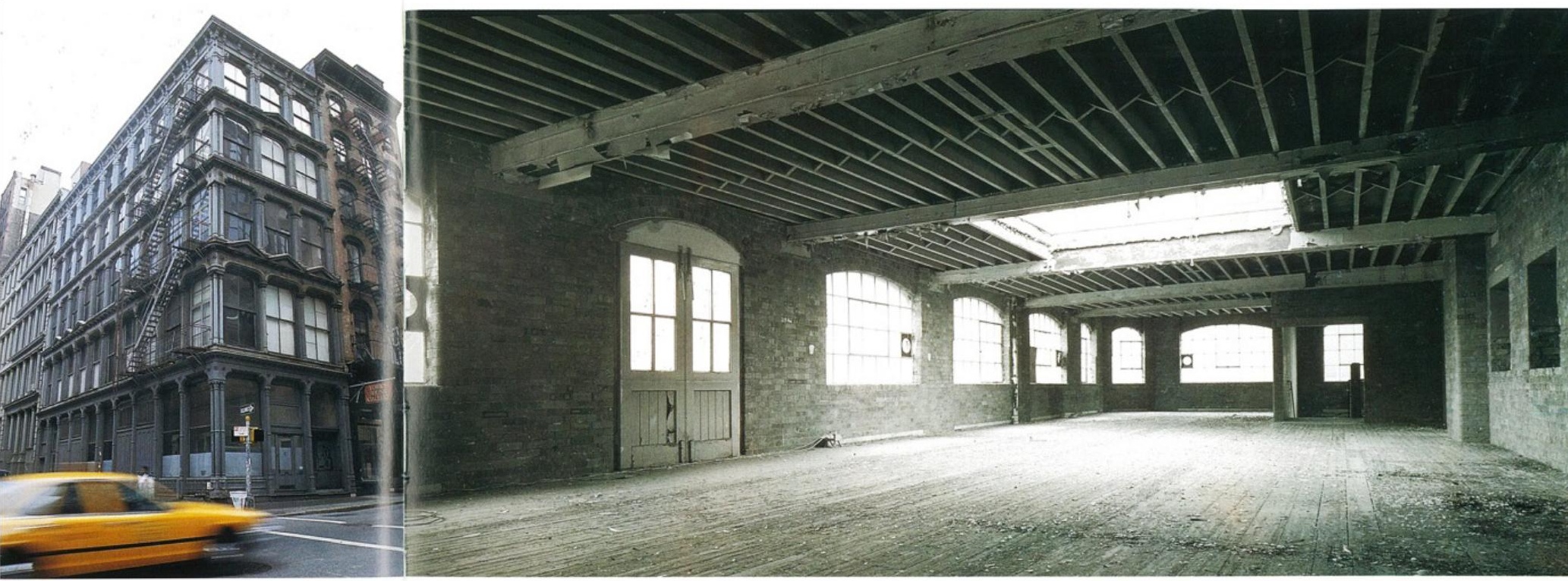

Fig 6. Loft Building in New York. Characteristics: open plan space, largely unaltered internally, large scale windows and exposed structural elements.

about a hundred feet long by thirty wide. A row of supporting columns ran down the middle, but otherwise it was clear, unobstructed space. Tall, grimy windows let in the distinctively white light of downstairs New York-also the roar of the trucks on Broadway. ..Paintings, combines, and sculptures from the recently concluded Jewish Museum retrospective were stacked against the wall farther along. There was a big table in the middle of the room, its surface cluttered with magazines, felt pens and pencils, and tubes of paint and other materials. Towards the back of the room, a counter projecting from the end wall formed an alcove for the refrigerator, the electric stove, and the bed-a mattress laid on the floor. All the rest of the loft was workspace. ${ }^{17}$

These humble beginnings and shabby impermanent interiors would later drastically change to modern, sleek interventions when the middle classes forced the artists out once the rent prices grew. The demise of the separate kitchen space in these lofts was already common, partly influenced by feminism, as Zukin states.

Unlike the rigid domestic division between "upstairs" and "downstairs", the housewife who did her own cooking did not readily accept an enforced isolation in the kitchen, away from the rest of the family. Early twentieth century feminists had demanded that the kitchen be eliminated entirely from individual homes and replaced with nearby communal dining halls. ..Frank Lloyd Wright's innovative houses opened up the kitchen to the dining room so

$17 \quad$ Zukin, S., Loft living : culture and capital in urban change. 61 that the "work-space", as Wright called it, flowed into the living area...suburban ranch homes had large efficient kitchens that flowed into multi-purpose "dens" or "family rooms". The open plan space of this suburban style, as well as the 1960s revival of Early American rural homes, and barns, prepared the way for the acceptance of living lofts. ${ }^{18}$

Early warehouse dwellers hid anything that would allow building or fire inspectors to find traces of habitation in these illegal buildings. Suzanne Slesin talks of the artists' manoeuvres and tricks to avoid being caught or evicted, ...beds were installed on pulleys that allowed them to be raised to the ceiling and hidden if a building or fire inspector came unexpectedly to call, groceries were not brought home in supermarket shopping bags; and residential garbage was frequently carried out of the neighbourhood or hidden under art work related debris. ${ }^{19}$

This need for secrecy is also the cause of why there was no fixed furniture or much attention paid to comfortable living. The space contained only the essentials for work and sleep. A sense of impermanence and temporariness was thus prevalent in these lofts. Part of the allure associated with loft living was the idea of impermanence. Because the space was largely open with no partitions or fixed walls, the space had the constant ability to change, defined only by the use it was given.

Artists were in turn also influenced by the now decaying

$\begin{array}{ll}18 & \text { ibid } 70 \\ 19 & \text { Slesin, S., The Book of Lofts., } 3\end{array}$


industrial aesthetic, paying homage to it in their work and living conditions, through holding on to the remnant of the past, yet recreating it in a new visionary way. They promoted the legacy of everyday industrial heritage by seeing the beauty in gritty buildings. ${ }^{20}$

\begin{abstract}
The increasing automation of industrial production and the accelerated depreciation of industrial machines that this caused inspired an artistic appreciation of older mechanical devices. $^{21}$
\end{abstract}

The reuse of warehouses in SoHo also played an integral role in rejuvenating the urban city centre by bringing people back. They found beauty in these decrepit warehouses, and an appreciation for all things nostalgic, perceiving their bare forms as aesthetically beautiful. They set a new trend, helping classify warehouse living as "hip and cool", and others wanting to emulate this lifestyle soon followed.

\section{The Abandonment of the City}

The doors to these warehouses and factories had closed, as businesses resettled miles away from their initial base. It became much easier to abandon these decaying buildings, rather than to clean them up and find new uses for them. However, their unique architectural style, including use of cast-iron ornamentation and structure, open plan layout, and historic significance, saved them from being torn down. These building represented an entire neighbourhood spanning several streets. In the late 1960s the SoHo area was considered for demolition to pave the way for the Lower Manhattan Expressway (LoMEX), providing a route connecting the Manhattan and Williamsburg bridges on the east, with the Holland Tunnel on the west. However, a young historic preservation movement and architectural critics together stopped the expressway from being built. They argued the area's cast-iron buildings held architectural significance, even though at that time this was not highly valued by the general public or contemporary business community. These qualities in fact became one of the major arguments for the preservation of SoHo in debates over proposed zoning and land use changes that occurred in the later phase of the process of succession. ${ }^{22}$

Considerable questions were posed as to whether it was more economic to tear the old disused buildings down, or to renovate them for new uses. They were unfit for much and were located in the manufacturing zone, which meant residential habitation was illegal.

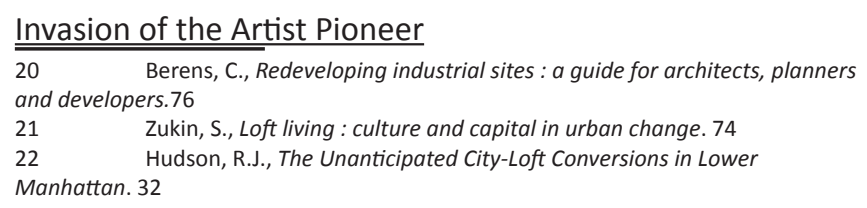

A pioneer is defined in the Oxford English Dictionary as, $A$ person who goes before others to prepare or open up the way; one who begins, or takes part in beginning, some enterprise, [or] course of action. ${ }^{23}$ The rejuvenation that was eventually instigated by the artists' infiltration of SoHo and the creation of lofts resulted in a pioneering cultural movement. This small group of people were the very first inhabitants of warehouses, using them as both work and living spaces, and using the existing buildings to suit their own needs.

Hudson refers to the term 'pioneer' as one that is seen in both biological and human ecology, as a term that is applied to the early entrants into a new habitat. He talks about the cycle that is created, where the initial pioneers help regenerate an area that is deemed uninhabitable. This area takes on a new life as interest begins to grow,

\begin{abstract}
The area generates "site modification" or change in the very environment that they are settling. The changes they produce in the area make it possible for other populations to follow; in the process, the initial pioneers are often ultimately displaced, as the developing community creates a new equilibrium. ${ }^{24}$
\end{abstract}

\section{The Artists and Suburbia}

The 1960s was a period known as the experimental era. Alternate lifestyles were evident as the public was no longer oppressed by the rigid confines of the common and suburban lifestyles. The artists were the first to move away from the conventional modes of living in the suburbs. They were in turn inspired by the Parisian communal lifestyle at the end of the $19^{\text {th }}$ Century, referred to as La Bohème ${ }^{25}$, often rejecting bourgeois and middle-class values. Sharon Zukin, the first academic to identify the significance of loft conversion, stated the following.

Until the 1970s, living in a loft was considered
neither chic nor comfortable...Making a home
in a factory district clearly contradicted the
dominant middle class ideas of "home" and
"factory", as well as the separate environments
of family and work, on which these ideas were
based.

Suburbia and all it entailed was still the dominating lifestyle choice of the American people, and it was impossible to imagine moving back downtown and living in a former factory. It was not until the mid eighties and nineties when a new class of citizen overtook the warehouses, once the area became trendy and prices rose steeply that the idea of living in a converted warehouse was deemed to be both

\begin{tabular}{ll}
\hline 23 & "Pioneer", Oxford English Dictionary \\
24 & ibid. 30 \\
25 & Field, M., and M Irving. Lofts.9 \\
26 & Zukin, S., Loft living : culture and capital in urban change. 58
\end{tabular}



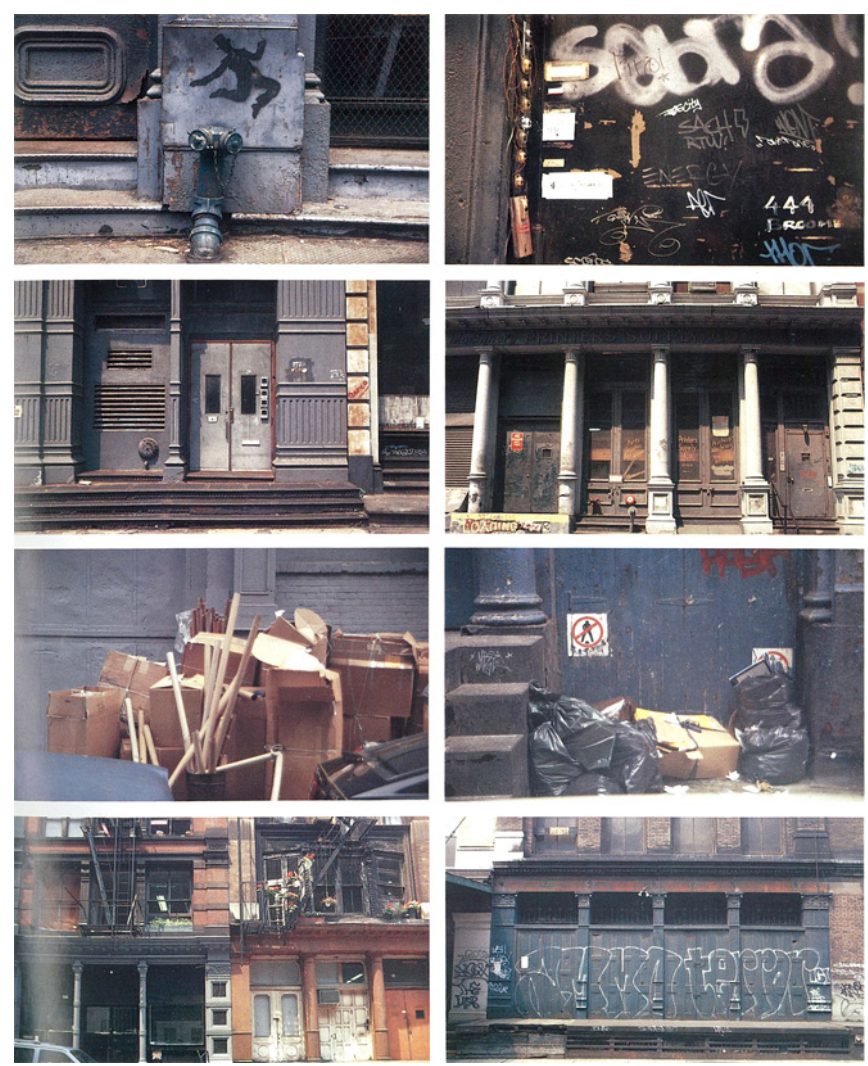

Fig 7. Early signs of residential inhabitation seen through garbage bags left outside

Table 3. Residentially converted buildings in Manhattan by area, legal status and receipt of tax benefits.

\begin{tabular}{lrrcc}
\hline Area & \multicolumn{3}{c}{ Residential conversions } \\
\cline { 2 - 5 } & Total & Legal & Illegal & $\begin{array}{l}\text { Received } \\
\text { J-51 }\end{array}$ \\
\hline SoHo & 178 & 13 & 165 & 6 \\
NoHo & 58 & 2 & 56 & - \\
TriBeCa & 224 & 5 & 219 & 1 \\
Midtown South & 320 & 10 & 310 & 5 \\
Northeast Village & 56 & 19 & 37 & 8 \\
Bowery & 51 & 2 & 49 & - \\
West Village & 10 & 5 & 5 & 2 \\
Lower Manhattan & 13 & - & 13 & - \\
Midtown C.B.D. & 59 & 1 & 58 & 1 \\
Madison Square & 8 & 7 & 1 & 3 \\
Murray Hill & 2 & 1 & 1 & 1 \\
Graphic Arts & 3 & 1 & 2 & - \\
\hline TOTAL & 982 & 66 & 916 & 27 \\
& & $(6.7 \%)$ & $(93.3 \%)$ & \\
\hline
\end{tabular}

Source: Residential Re-Use 1977.

Fig 7b. Legal vs. illegal conversion chic and acceptable. This was the complete opposite of the kind of lifestyle the artist sought to establish in these same conditions.

Artists also found loft and warehouse spaces ideal because the existing structure of the buildings provided what they required; space to live, work and display their work, as well as cheap rent, an abundance of open unobstructed space and natural light. The Art Movement* was in full swing during this period of the 1960s and New York was the capital of the art world, having superseded Paris. Pop Art, Fluxus Op and other experiential art forms were being practiced, pioneered by some of the most influential artist of the time. Andy Warhol, Jean-Michel Basquait, Roy Liechtenstein and Yoko Ono were among several influential artists who were producing work of international acclaim and living in lofts. These lofts suited their lifestyles and they were able to associate with other artist types with similar interests and backgrounds. Andy Warhol lived in a warehouse known as the "Factory", where he worked and lived, producing works such as the iconic "Campbell's Soup Can" among others. The "Factory" became the great "happening" of the 1960s New York culture. $^{27}$

Loft living paved the way to a lifestyle that granted greater freedom from prejudice. Living in these converted lofts allowed for expression of individuality as well as interior dwelling. Early inhabitants were initially composed almost exclusively of artist-painters, sculptors, dancers, and print and video and film makers. This community of artists that infiltrated the area provided a social and professional network for pursuing artistic careers, and the location of SoHo was where much of the current history of contemporary art was being made. ${ }^{28}$

A 1987 article written by David B. Cole described the artists as

... victims of capitalistic market forces, but occasionally they are depicted as aggressors in significant urban land use changes. Their role as urban pioneers is both romanticized because of their willingness to live in run-down areas with old factories and warehouses or to break racial and ethnic boundaries, and politicized because they displace low-income groups and initiate gentrification that benefits land speculators, developers, realtors, and ultimately the upper middle class. ${ }^{29}$

$27 \quad$ *Art Movement-Modern, Pop Art, Op Art, Fluxus among others were produced by influential artist in New York at this time, gaining international acclaim. George Maciunus, a Lithuanian born artist and believed to be the first SoHo warehouse resident organised the first Fluxus event in the AG Gallery in New York. ibid. 59 28 Hudson. R., The Unanticipated City-Loft Conversions in Lower Manhattan. 31

29 David B. Cole. "Artists and Urban Development". The Geographical Review. Oct 1987. Vol 77. No 4. 391 
Bridget Franklin describes the display of individuality in artists' living quarters. Initially seen as outcasts the artist did not care whether he or she fitted into any class system, instead choosing to form his or her own community and lifestyle.

\begin{abstract}
Seeking to differentiate themselves from other social groupings, they developed lifestyles based on particular modes of consumption, and in which the cultivation of an aesthetic taste, the search for authenticity and the display of cultural capital were important markers of destination. Disdaining suburbia as passé, repressive and synthetic, they sought authenticity within the city in places resonant of history, culture or distinctive architecture. ${ }^{30}$
\end{abstract}

In a way artists were disassociating themselves from the social prejudices of the suburban standard. Loft living represented the effort to replace the intense privacy of the detached suburban house with a more public space. In most lofts, the open expanses of space uninterrupted by walls or doors, open every area and every social function to all comers, and this creates an impression of informality and equality. The absence of architectural barriers between service and entertainment areas eliminates the hierarchy of functions that is typical of most household arrangements, as well as the hierarchy of persons-either male or femalewho perform those functions. ${ }^{31}$

The appropriation of a large space in a loft
also reverses the sixteenth century association
between small rooms and self expression. ${ }^{32}$

Because of the structure of many small industrial buildings, most lofts are entered directly from the elevator. So guests penetrate immediately into the living area. This contrasts with the gradual transition between "outside" and "inside", and public and private space, in a typical home. ${ }^{33}$

\section{$\underline{\text { Re-Zoning }}$}

Residential use of buildings in manufacturing zones and buildings without a residential Certificate of Occupancy from the Buildings Department were prohibited by City and State laws. The artists, however, sought working space rather than the creature comforts or other safeguards which the building codes enshrined. For their purposes, freight elevators, crude sanitary facilities, sporadic heating and the limited services available in predominantly industrial neighbourhoods were regarded as relatively

\begin{tabular}{ll}
\hline 30 & Franklin, B., Housing Transformations-Shaping the space of $21^{\text {st }}$ century \\
living. 198 & \\
31 & Zukin, S., Loft living : culture and capital in urban change. 68 \\
32 & ibid 69 \\
33 & ibid
\end{tabular}

minor inconveniences for which ample space and low rents were ready compensation. ${ }^{34}$ The small community of

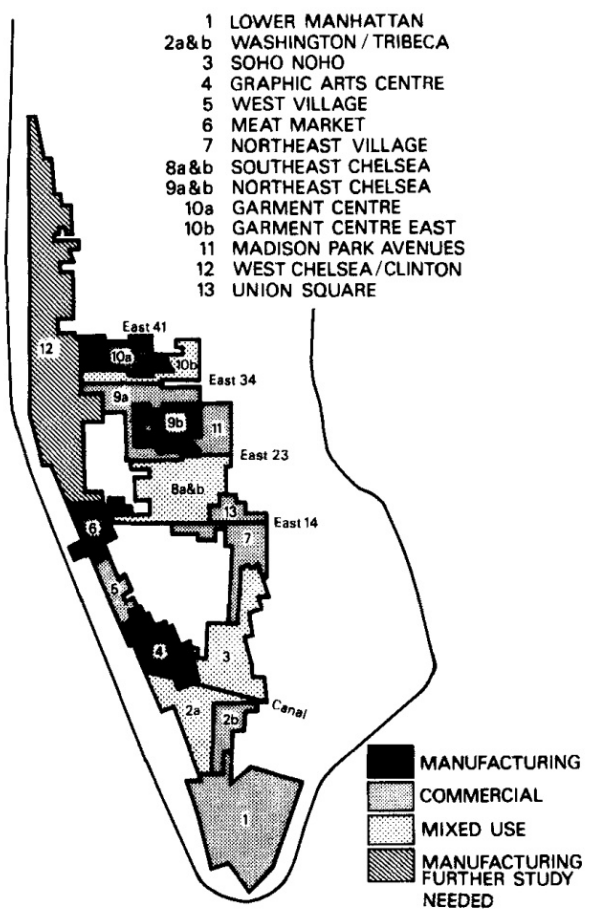

Fig. 1. Land use zoning measures in Lower Manhattan. April 1981.

Source: Lofts: balancing the equities. New York City Planning Commission, April 1981.

Fig 8 Land use zoning measures in Lower Manhattan, showing SoHo area was located in the mixed use area, surrounded by manufacturing and commercial activities.

growing artists later formed a coalition, the Artists' Tenants' Association, lobbying for more sympathetic treatment of their rights to legal occupancy in New York's warehouses and other converted buildings. ${ }^{35}$ The area that was seen as a decrepit former warehouse and merchandise area had now begun to prosper into a booming art and tourist area, and the artists were granted residency as the zoning laws were amended. In 1971, State law was amended to ease building restrictions on residential and nonresidential loft conversions and to simplify the certification of artists' professional status. Since 1972, the Department of Cultural Affairs certified almost three thousand artists for the purpose of gaining legal entitlement to loft living in designated areas. ${ }^{36}$ Living in lofts in Manhattan, the heartland of loft living was illegal only until 1976. ${ }^{37}$

\section{Gentrification}

The fact that these new neighbourhoods were developed in $34 \quad$ Jackson., P., Neighbourhood Change in new York:The Loft Conversion Process. 2

35 ibid. 4

36 Field, M., and M Irving. Lofts. 5

37 ibid. 75 

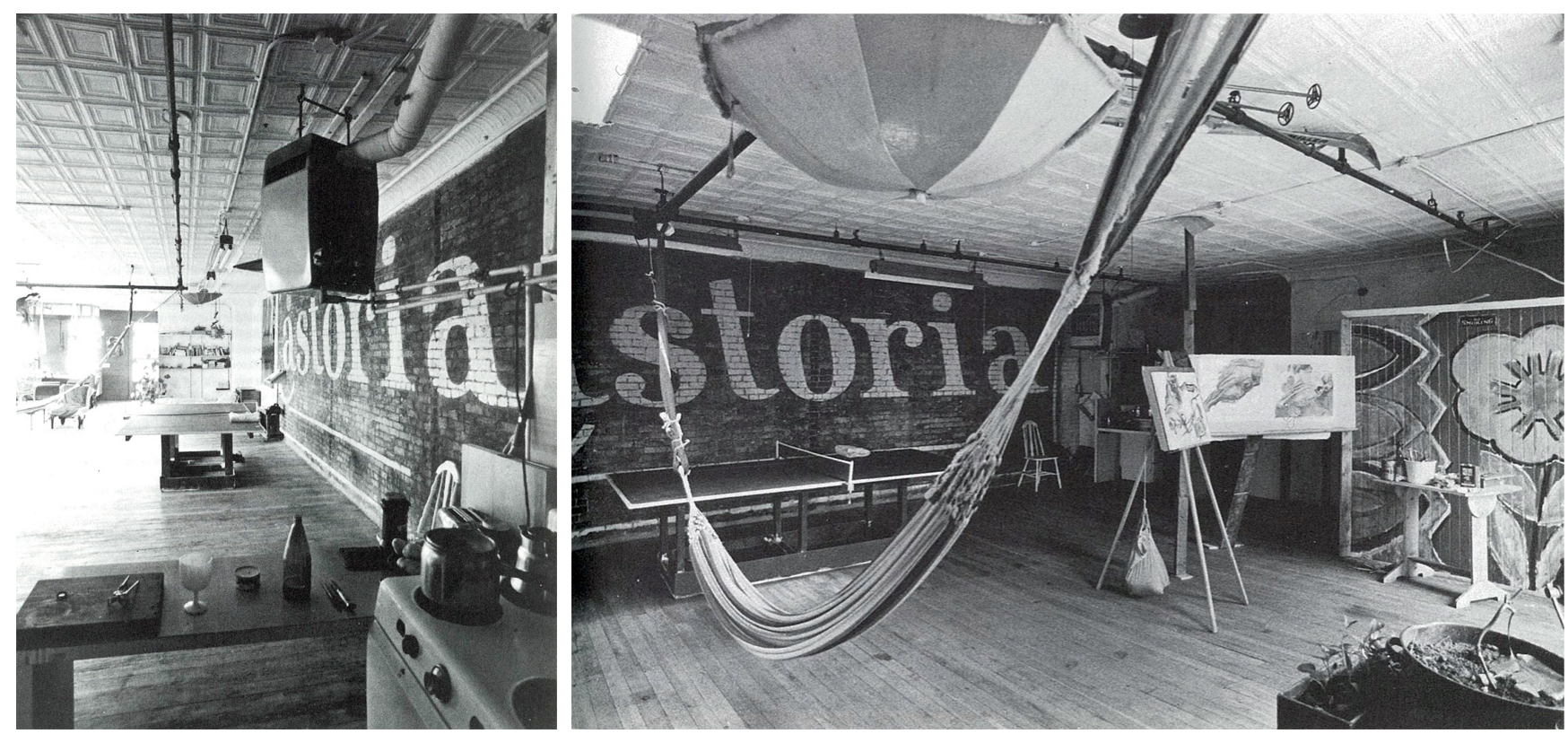

Fig 8 b. Pioneering artists used the space for work and living, with minimum intervention to the space. These images demonstrate the mixed 'work' and 'live' activities were combined in the space. The absence of walls further enhanced this. The kitchen space is bare minimum and signage from the lofts original use is present.

areas where there was previously no residential amenities alludes to the idea of creating a living environment from scratch. There was previously nothing in the area of SoHo that resembled a community. Amenities and shops associated with a residential area were uncommon. It was hard to imagine that in these neighbourhoods people resided behind the austere walls.

\begin{abstract}
Instead of dry-cleaners and grocery stores, one would be more likely to find corrugated box suppliers and machine repair and tool and shops. Streets are often lined with trucks and there is an absence of trees, parks, and playgrounds. The loft structures themselveswhether in London's Docklands, near Paris's Place de la Bastille, on in New York's SoHo or Tribeca-are usually large structures with awesome, rugged exteriors that do not exude familiarity, 'hominess', and sense of stability... ${ }^{38}$
\end{abstract}

The evolution of SoHo was due to a small number of people who sought out this area, seeing its potential and revitalising it. The zoning regulations were later amended from a purely manufacturing area to one for residential inhabitation as more interest in this area grew.

Artist pioneers are often referred to as gentrifiers. Once they had taken over these vacant warehouses the art market followed them, and thus an entire art community was formed. Eric Homberger describes the transformation of SoHo into a popular art community.
As the number of artists grew, the area attracted dealers and small galleries, which were followed by bigger galleries (the Guggenheim/SoHo at 575 Broadway, the new Museum of Contemporary Art at 583 Broadway...) boutiques, coffee shops, smart clothing shops, and much more, transforming SoHo by the 1970s into one of the most soughtafter places in New York. ${ }^{39}$

The loft living movement eventually spread, creating interest among the wider public. Inner city living once again became regarded as a trendy and popular thing to do. What began as a marginal phenomenon was eventually seen as fashionable and become sought after.

The gentrification process occurred when the middle class came to the realisation that there was economic and cultural value in this derelict but up and coming neighbourhood and that investing in warehouse property was economically strategic. The derelict neighbourhoods were resuscitated thanks to the creativity and initiative of the pioneer artist, but inevitably when this area began to prosper the artists were the first to leave. SoHo, as a neighbourhood increased dramatically in economic value, and property prices drastically increased, ${ }^{40}$ introducing a new clientele of resident who sought the inner city lifestyle and could afford the new higher priced warehouses. This brought in a lot of people, institutions and money and eventually and inevitably resulted in the expulsion of the artists. ${ }^{41}$ Sharon Zukin explains this as an evolutionary process stating that what started out as a

\footnotetext{
39 Homberger, E,.New York City: a cultural and literary companion. 198

$40 \quad$ Lorente, Jesus Pedro., Art Neighbourhoods, Ports of Vitality. 94
}

41 ibid 


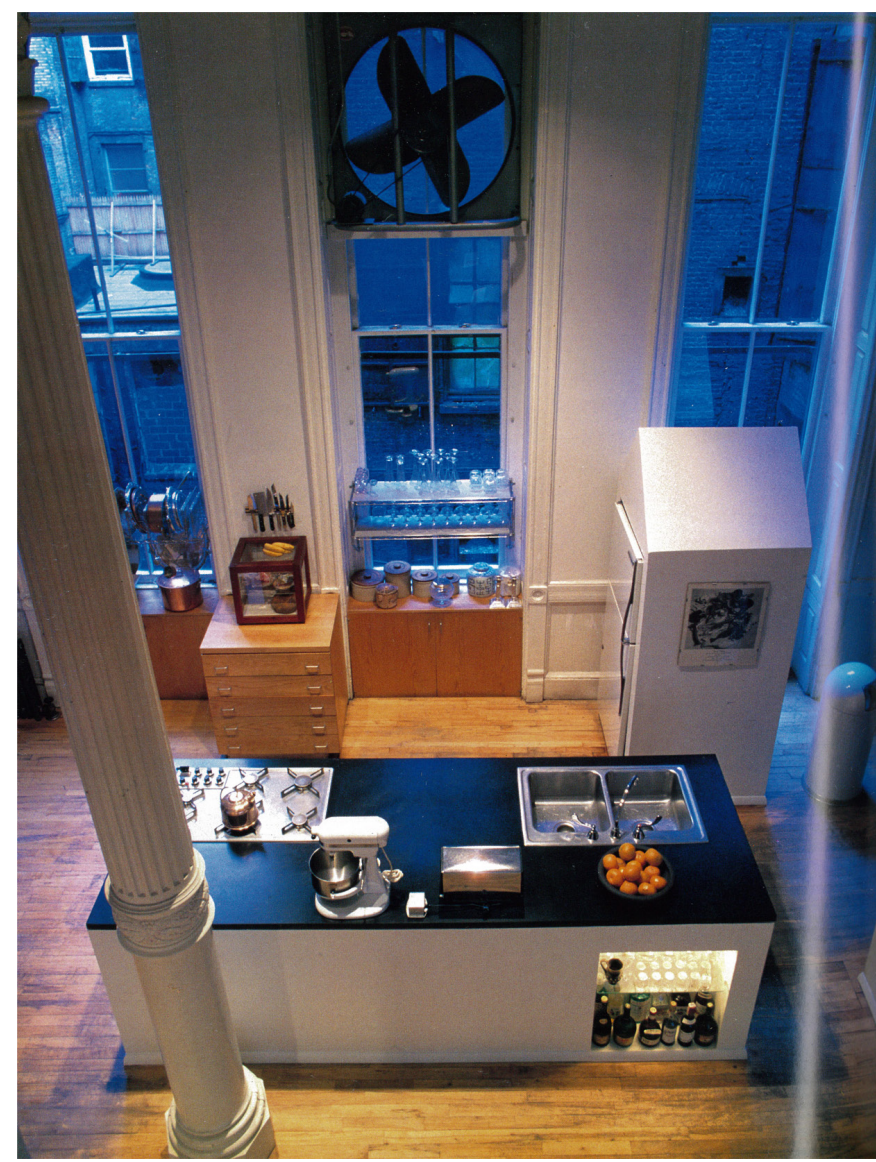

Fig 9. Double height spaces and free standing island style kitchen are common in converted warehouses/ lofts.

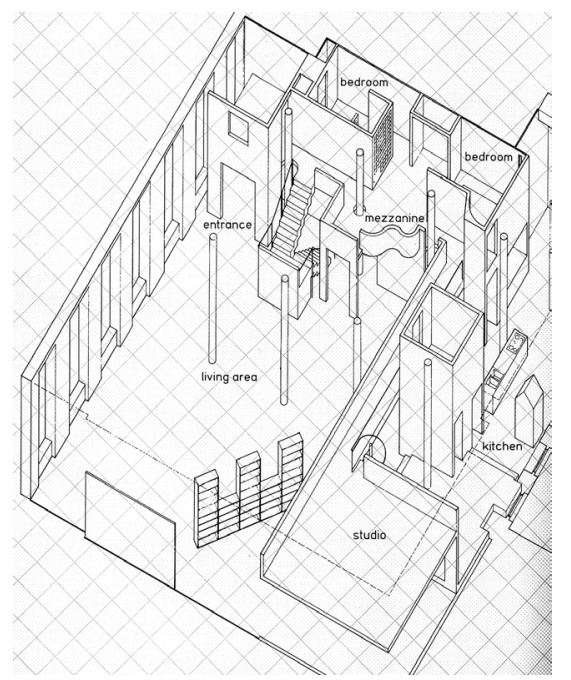

Fig 10. Axonometric Plan of apartment in Fig 11, showing mezzanine level with bedrooms overlooking the main living area

trend turned into a 'movement' and finally transformed the market. ${ }^{42}$ Bridget Franklin describes how the initial pioneers who had first discovered and rejuvenated the area eventually created a popular rejuvenated neighbourhood that was sought after by high income earners wanting to move in and $42 \quad$ Zukin, S., Loft living : culture and capital in urban change., 14

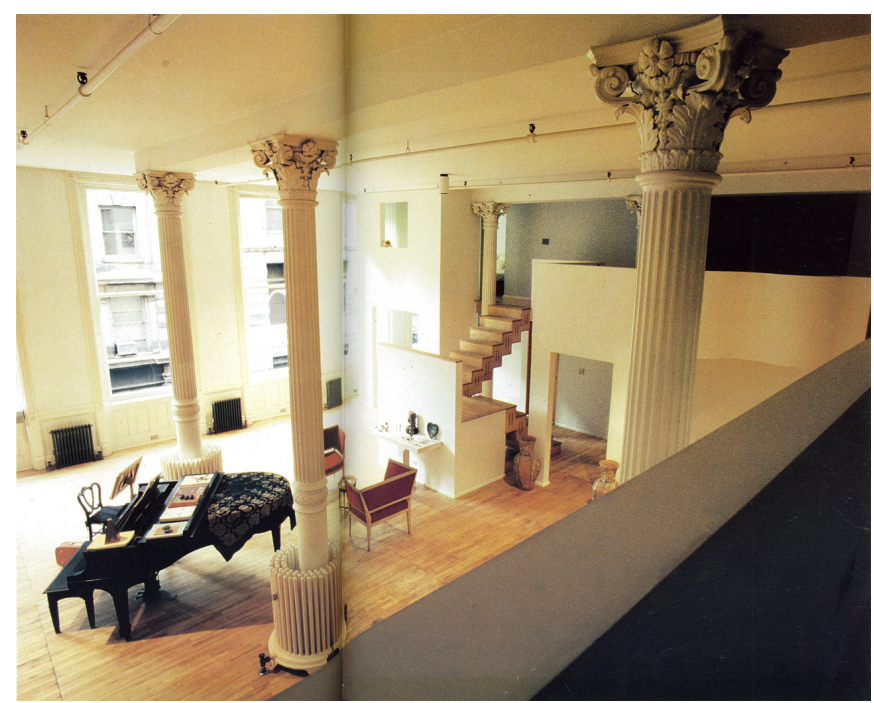

Fig 11. Mezzanine level looking down onto the living area. Grand floor to ceiling heights and cast iron columns are visible.

invest in these warehouses.

\begin{abstract}
By the mid 1970 s rents were rising, and professional developers, encouraged by the city governors, realised that there was development potential. Their activities meant that by the 1980s most of the artists had moved out, displaced by the institutionalisation of loft living and by the commodification of the space they had 'discovered' for the benefit of those pursuing a lifestyle of 'bourgeois chic' ${ }^{43}$
\end{abstract}

What was previously considered an unacceptable way of life ${ }^{44}$ became trendy, fashionable and sought after. A new equilibrium was inevitably created as the new developing community forced the initial pioneers out. A new class of people were now making their way into the loft living lifestyle. Middle class, well educated and affluent professionals were attracted by the general ambience and glamour of the art world. A fashionable new urban lifestyle emerged as real estate developers moved quickly to invest in the conversion of larger loft buildings for cooperative sale or luxury rental. As a result, lofts became smaller, and both rents and cooperative prices rose per square foot. An evaluation of prices in the Village Voice newspaper in August 1982 showed the mean monthly rental prices rise to around $\$ 1200$ for an average sized loft of 1750 square feet $\left(175 \mathrm{~m}^{2}\right) .{ }^{45}$

\section{Modern Conversions}

The process started with traditional industry, particularly the garment trade, moving out or closing down. The artists took over the cheap

\begin{tabular}{ll}
\hline 43 & Franklin, B., Housing Transformations-Shaping the space of $21^{\text {st }}$ century \\
living. 198 & \\
44 & Zukin, S. Loft living: culture and capital in urban change.14 \\
45 & Jackson., P., Neighbourhood Change in new York: The Loft Conversion \\
Process.6 &
\end{tabular}




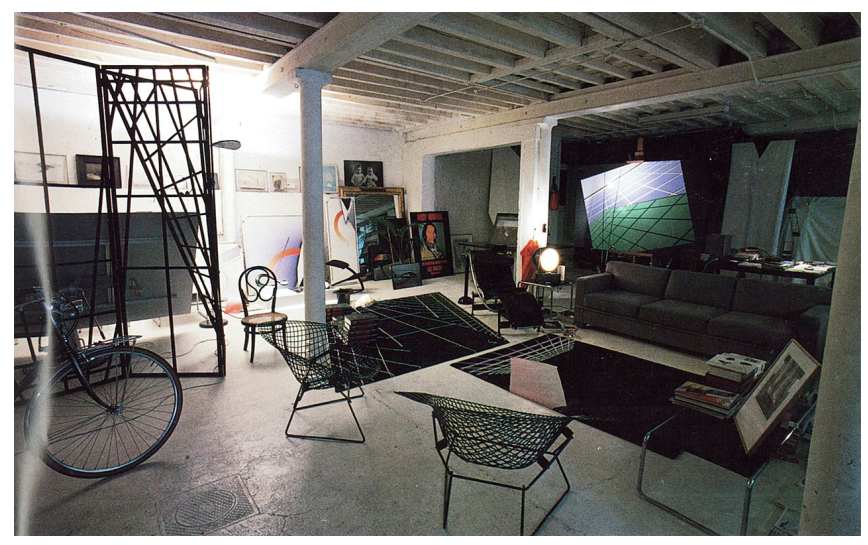

Fig 12. Working and living space

space they left behind. This made the idea chic, and the middle classes followed in what became a cult. Large basic shells gave way to small, luxury flats. ${ }^{46}$

This change in loft size and insertion of interior walls showed the domestication of loft living. The next generation of warehouse dwellers who settled into these buildings were,

\begin{abstract}
...metropolitan orientated, ultra cool, twenty, or possibly thirty something, probably working in the cultural or creative industries, and attracted to loft living by the architecture, space, inner-city location, and the urban lifestyle. $^{47}$
\end{abstract}

The division of the loft space into smaller rooms and sectioning of one space into several was one of the latest stages in the gentrification and changing attitudes of the new warehouse resident. This was seen through practical spatial considerations pertaining to family life: space divisions and insertion of walls to create more distinction between spaces and public and private zones, mezzanine levels, and distinct separation of living and working areas. However, the loft was a showcase for experimental architecture. There was no one warehouse look and the generic spatial structure allowed the inhabitant to create a home that was uniquely theirs. The residents were unconstrained by walls, styles, and were free to create their unique vision. The spaces ranged from the conservative minimal to the creative as most were without architectural detailing, but blank canvases upon which each person could instil their own identity.

The domestication of warehouse living occurred when this form of living became acceptable. This also played an important role in domesticating the industrial aesthetic. ${ }^{48}$

Emma O'Kelly, in her book Conversions, describes the

\begin{tabular}{l}
\hline $46 \quad$ Ibid.338 \\
$47 \quad$ Hamnett, C and Drew, Whiteleggô., Loft conversion and gentrification in \\
London: from industrial to postindustrial land use. Vol 39.106-124
\end{tabular}

$48 \quad$ Zukin, S. Loft living : culture and capital in urban change. 73 evolution of the warehouse movement as an economically successful property investment.

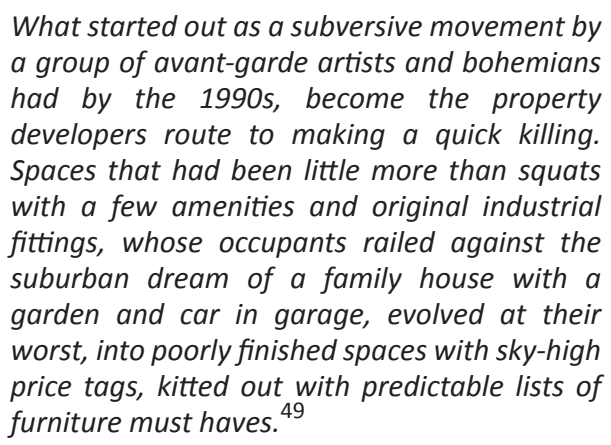

The statement above suggests that warehouse living was beginning to lose its authenticity and exclusivity. It was becoming generic, less innovative and common.

According to Zukin, the price of rents in the East Village was in $2007, \$ 35$ and $\$ 100$ a square foot, or $\$ 3,500$ to $\$ 10$, 000 a month. ${ }^{50}$ An attraction of the style of living was the close proximity to the city centre and the accessibility to both work and social facilities. ${ }^{51}$ It was no longer seen as place inhabited by the stereotypical single and childless income earner or yuppie (young urban professionals) or artist, but now included families and those with children. To accommodate the new higher paying and demographic of residents, the loft aesthetic began to change,

\begin{abstract}
Gleaming lofts with clean white walls, high ceilings, industrial fittings, and acres of wood floors appeared in design magazines...touting the latest "industrial chic". Artists were soon priced out of the neighbourhood and began the search for other areas that had large spaces and moreover were affordable $e^{52}$
\end{abstract}

However, the major principles of what defined converted warehouse spaces remained,

While much of what was fashionable during the sixties has thankfully gone by the wayside, the look of exposed structure as an interior decorating scheme has stayed with us as an icon of the trendy interior. An interior wall of roughly pointed common brick still seems to many people to have the air of cosmopolitan sophistication. Unless a contemporary builder contrives to recreate original elements and artificially distress expensive new brick and timbers, this look can be achieved only when

\begin{tabular}{|c|c|}
\hline 49 & O'Kelly, E and D Corinna., Conversions.10 \\
\hline 50 & Zukin, S. Naked city: the death and life of authentic urban places, 262 \\
\hline 51 & Hamnett, C and D Whiteleggô., Loft conversion and gentrification in \\
\hline \multicolumn{2}{|c|}{ London: from industrial to postindustrial land use.Vol 39.106-124 } \\
\hline 52 & Berens, C., Redeveloping industrial sites : a guide for architects, plo \\
\hline
\end{tabular}




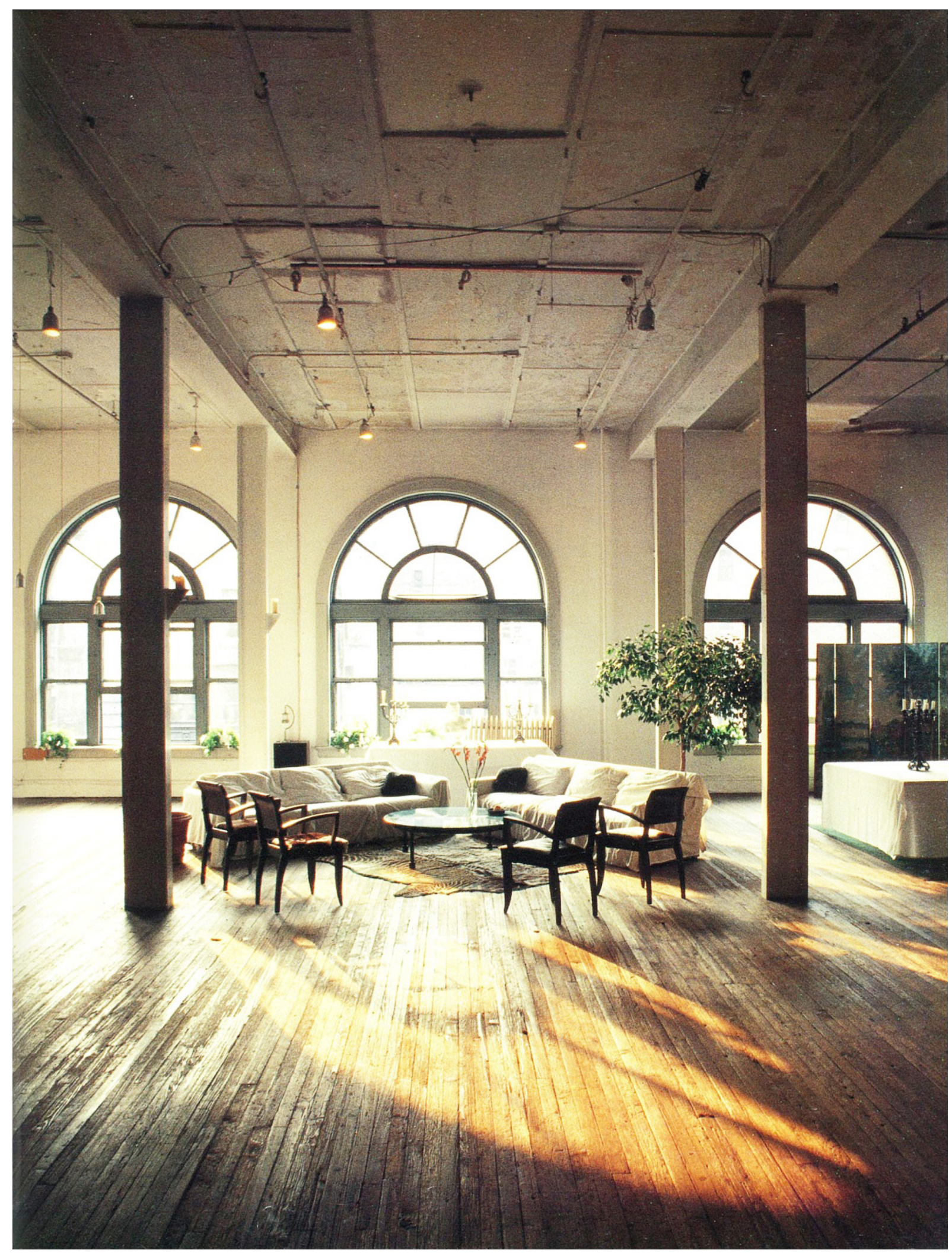

Fig 13. Bare floors, exposed ceiling, exposed columns, double height space, large full height windows, absence of partition walls, standard features in a converted warehouse space 
you start with an old building. ${ }^{53}$

In SoHo, New York, the loft living phenomenon spread to the middle classes and other potential residents in the 1970s. This way of living became sought after not just by artists,

\begin{abstract}
...the demand for loft living spread beyond the downtown neighbourhoods to the more traditionally minded members of the middle class who wanted more space and were attracted to the new way of life that the location and expansiveness of lofts promised. Loft newsletters, Loft cooperative boards, loft legalization, and the support of lawyers and business men, city planners and architectssome of them recent loft residents-made the public and city officials aware of the potential and power of the new movement. Municipal authorities finally recognized the viability of loft living and forced changes in zoning laws that allowed for the occupancy of the former warehouses and factories. 54
\end{abstract}

Many people chose to live in lofts because the space itself appealed to them. On one hand, they liked the giant scale or "raw", unfinished quality of a loft, on the other hand they identified with the sense of adventure or the artistic ambiance which still remained with living in a loft neighbourhood. ${ }^{55}$ The changes that occurred in the loft aesthetic can be attributed both to changes in cultural and aesthetic standards.

Nowadays, in most urban industrial conversions, the property developers will already have fixed the roof, defined common parts, and supplied plumbing and electric services. Often, apartments are sold as shells with the side walls of the prospective homethose to be shared with the neighboursdefined only by a single course of blocks. The layout of the rooms is left to the buyer, the only restriction being the position of the drains, which determine the site of the kitchen and the bathroom. ${ }^{56}$

Demand for retail space on the ground floor and loft residential space upstairs became so intense that many artists could no longer afford to remain in SoHo. Lofts that had been purchased for less than $\$ 10,000$ in the late 1960s were selling for half a million dollars or more 20 years later. ${ }^{57}$

Similar results were achieved in other areas (e.g Tribeca and the West Village) that may Ibid. 46 ibid

Zukin, S., Loft living : culture and capital in urban change.61 Niesewand, N., Converted spaces., 11

Garvin, A., The American city: what works, what doesn't., 490 have not had as many cast iron structures, but had a similarly obsolete stock of warehouses and multi-storey manufacturing lofts. ${ }^{58}$

It is somewhat a paradox that a building initially built to house heavy equipment, utilitarian in style and devoid of any articulation or intention for artistic flair was now the container for the production of art and experimentation in an abstract and creative field. Industrial buildings were often designed by anonymous architects, ${ }^{59}$ as they were never intended to be buildings that were representative of good examples of architecture. They were simply built to serve their purpose. Just like the anonymous architects who built these buildings their first inhabitants preferred to keep their existence a secret.

Another paradox that existed in the warehouse building is the relationship of the external to the internal atmosphere. The bleak industrial exterior was a mere cover that enveloped the home situated inside. The stark, unadorned facades of typical factory and warehouse building (with the exception of the cast iron adorned facades of SoHo lofts) concealed the new life that was evolving inside. The architectural movement of renovating industrial warehouse buildings into residential dwellings became itself an innovative and creative movement. Their large expanses allowed the inhabitant and architect to experiment with the design and create individualistic living spaces, with the freedom to showcase and practice experimental architecture.

There was no one loft look, rather the spaces leant themselves to styles that were created based upon individual interpretation style and flair. The core structure acts as the detailing itself, with the long rows of windows, skylights, exposed brick wall, concrete or timber flooring and unbroken expanses. The engineering was thus emphasised, through its exposed and unsealed features, such as exposed piping and ceiling joists, brick walls and bare concrete floors. It was this hard, raw unfinished essence that was part of the building's unique character and charm that attracted the residents.

\section{$\underline{\text { Finishes and Interior }}$}

The great SoHo contribution to the practice of interior design was the residential habitation of open space in an industrial building. Isolated individuals may have done this before, but never had so many renovated so much so tastefully. SoHo artists led the way. Factory space was "gutted" prior to reconstruction from within to meet the owners' needs, usually to sizes much greater than those favoured by commercial developers so eager to get the most profit from every inch.

$\begin{array}{ll}58 & \text { ibid. } 491 \\ 59 & \text { Berens, C., Redeveloping Industrial Cities. } 23\end{array}$




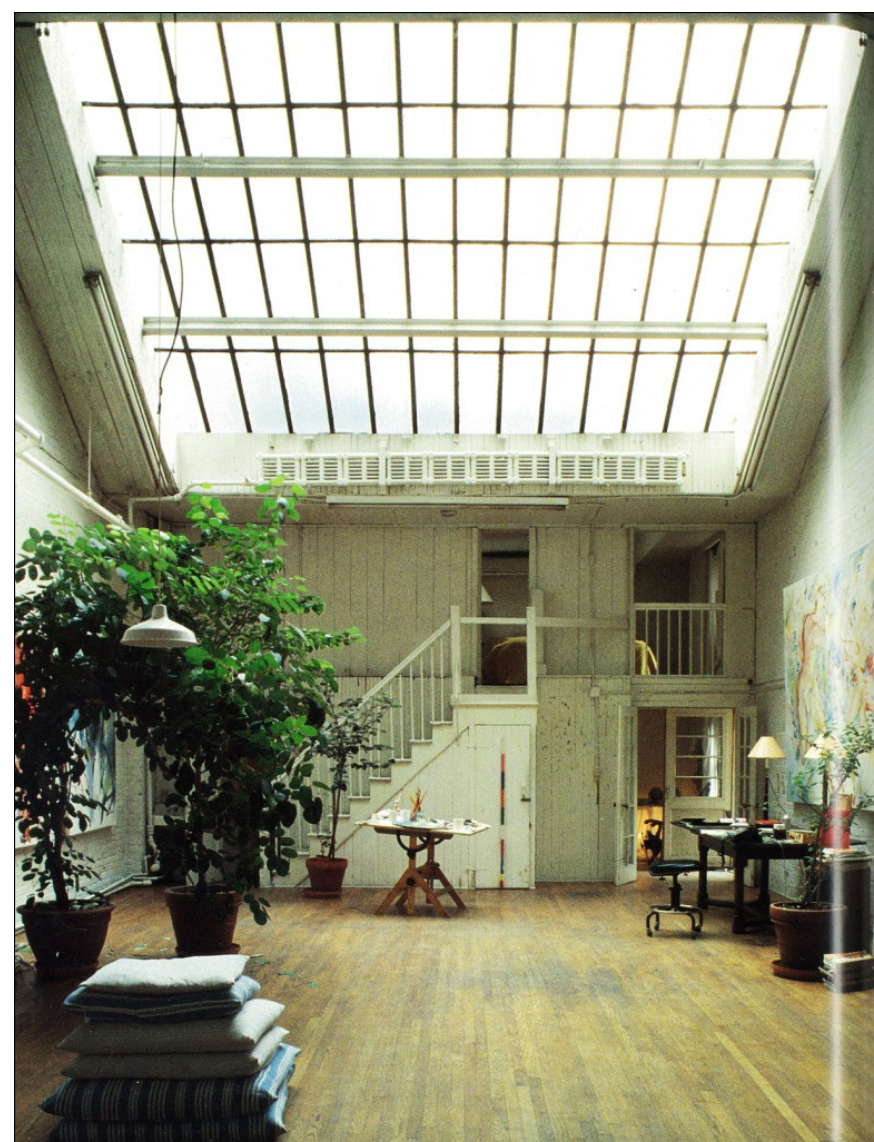

Fig 15. Abundance of light, in a loft space bedrooms are located in the mezzanine area, whilst the white paint treatment provides a blank canvas. The timber floor is kept in its original state.

...the industrial materials found in lofts are becoming increasingly common in typical homes. The pages of any decorating magazine picture concrete floors and counter tops, walls of exposed brick, and large exposed ceiling beams. In suburban homes everywhere, kitchens include stainless steel refrigerators and ranges, while baths feature plumbing fixtures with chrome fittings and deliberately exposed piping. ${ }^{60}$

The interior finish of a loft, became widespread globally as described above through publication and eventual world wide trend. Similarities and differences in the interior design will be analysed among the four different cases in the latter chapters of the thesis.

It can be argued that a building gains value over time. It is interesting to note that architecture of the past, although first ignored, eventually becomes appreciated for what is was, in the present. This is significant in the case of warehouses. These buildings, built between 1820 and 1880, were cast in standardised iron parts that could be ordered from a catalogue, and put together and taken apart at will. $60 \quad$ Tolliver, J., loft style, 10
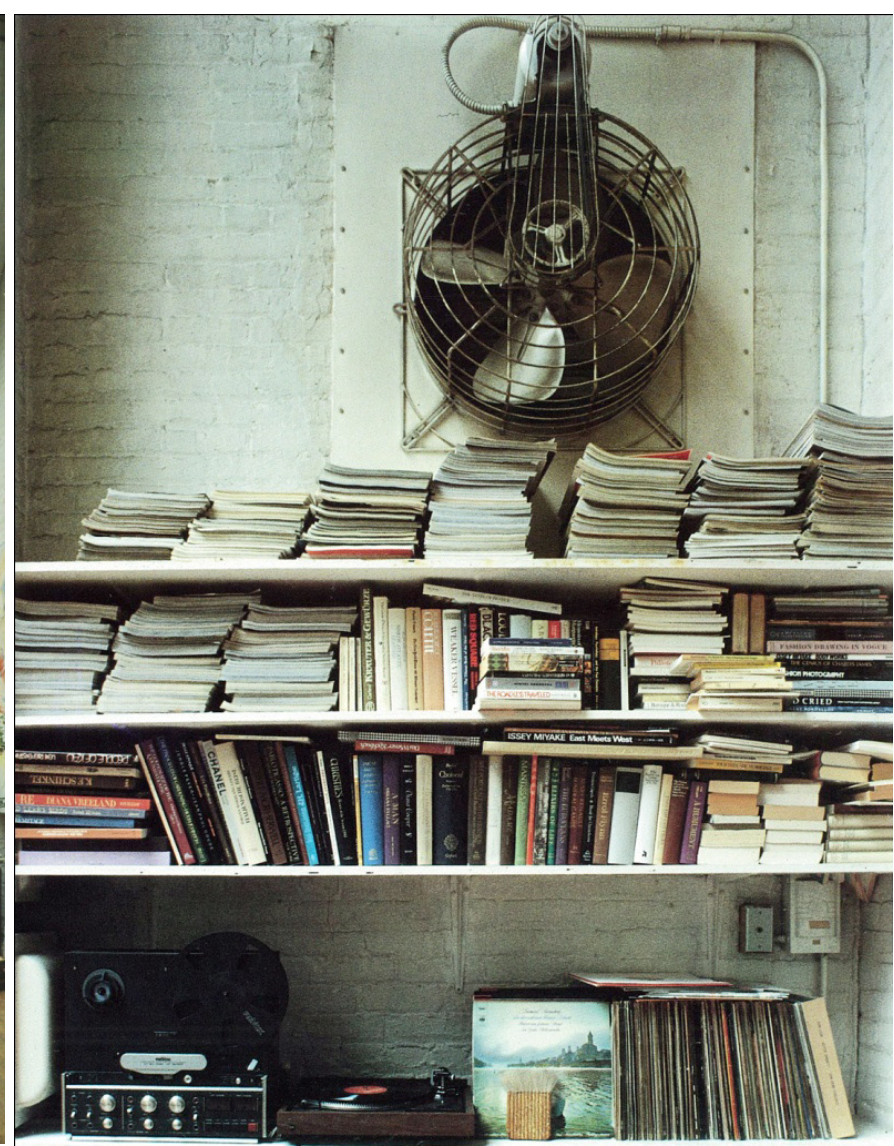

Fig 16. White washed brick and the absence of covered storage. This approach of displaying objects out in the open was common in early loft examples.

Ironically, the mass production of an earlier industrial era looks to modern eyes like individuality. ${ }^{61}$ Moving into a new era, a nostalgia for architecture of the past becomes apparent. The structure of warehouses had both the solidity and gracefulness that suggested a time when form still identified "place" rather than "function." 62

\section{Kitchen and Bathroom}

Kitchen and bathroom design has changed since the initial makeshift kitchens and bathrooms in the early artists' lofts. The artist simply installed a tub in the living room and created a kitchen by plugging a crock-pot into the wall. Modern lofts draw on more conventional kitchen design. The use of stainless steel and chrome is particularly appropriate in lofts given the powerful presence and history of metal in these former industrial buildings. Chrome, which was a much cheaper option to stainless steel, can often be found in kitchen and bathroom spaces .

Soon after homeowners became enchanted with the commercial look in their kitchens, they started to incorporate it into their baths.

61 Zukin, S., Loft living : culture and capital in urban change.59 62 ibid 


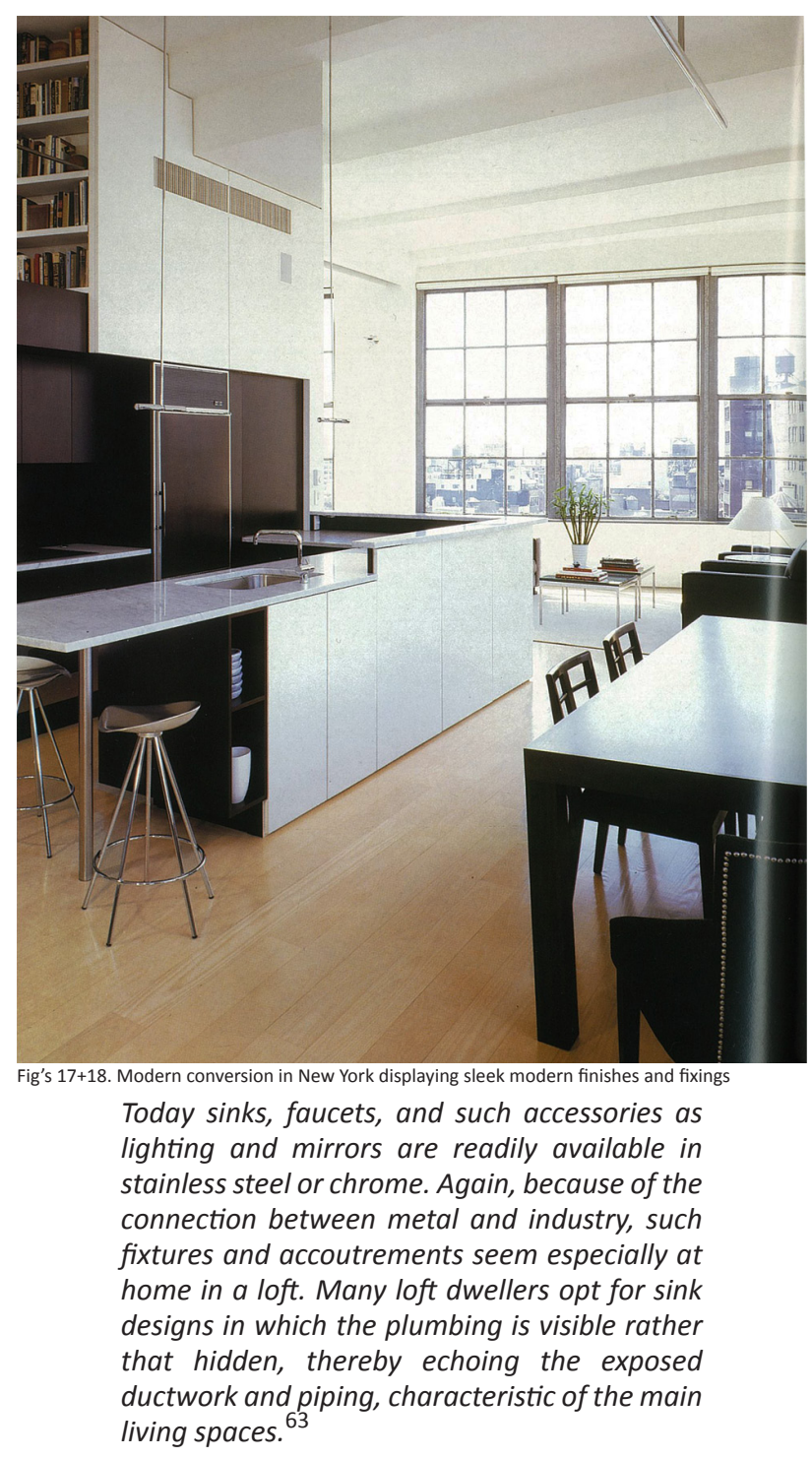

The cycle of repetition became evident in architecture through the conversion of old historic buildings and manifested itself in many ways: the passion and interest for older things and artefacts, the collection of antique furniture and belongings, and an appreciation for things manufactured in the last quarter century culminating in a nostalgia for the past. It is often only when something is long forgotten and is rediscovered that it becomes exciting and new again. Loft living artist pioneers found beauty as well as practicality in these old former commercial buildings, and these things became facilitators of their present use. They saw them as possessing potential for reuse and habitation. As Sharon Zukin stated,

The changing appreciation of these old loft buildings also reflects a deeper preoccupation

63 Tolliver, J., loft style.66

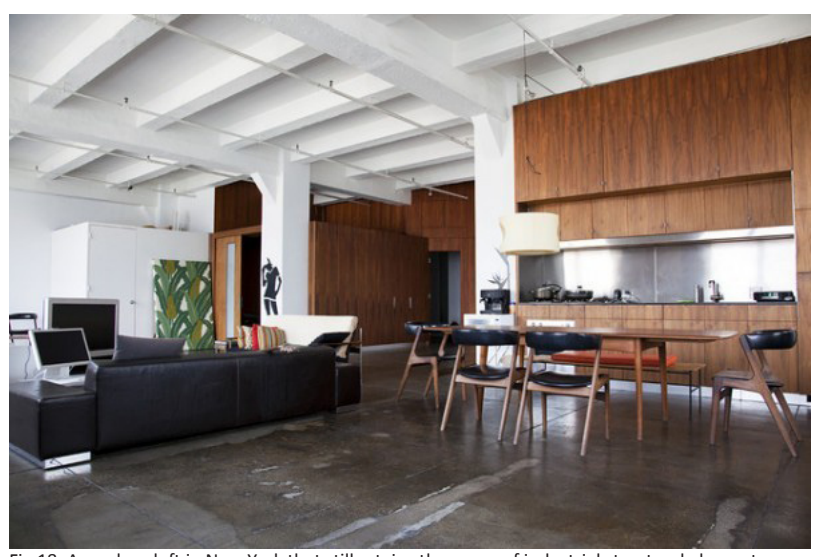

Fig 18. A modern loft in New York that still retains the sense of industrial structural elements. Absence of carpet and concrete floors, exposed ceiling joists, minimal partitions.

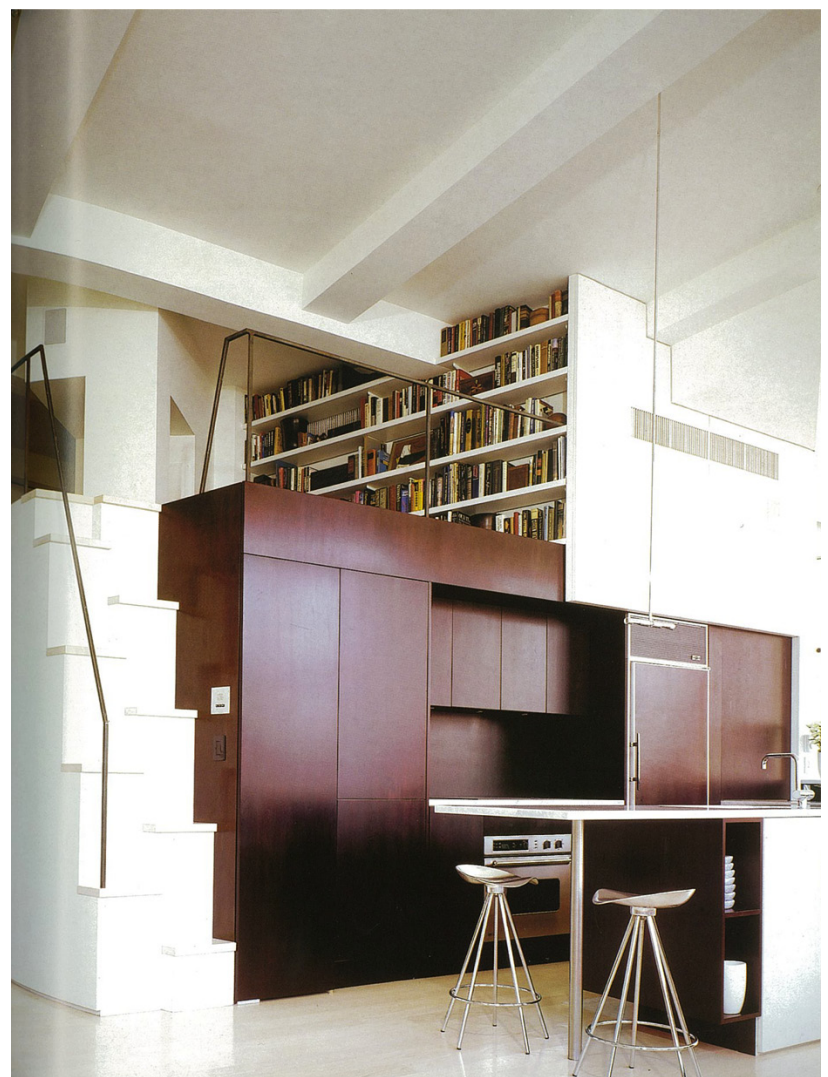

Fig 19. Modern Conversion. As opposed to early examples, there is a visible introduction of cupboards and sealed storage spaces, the ability to hide belongings and objects.

with space and time. A sense that the great Industrial Age has ended creates melancholy over the machines and the factories of the past. Certainly such sentiments are aroused only at the end of an era, or with a loss of function...We visit the docks in London but not in Rotterdam because commerce is romantic only when it has vanished. ${ }^{64}$

Due to the initiative and vision of some social outcasts, these historic buildings, examples of the technological $64 \quad$ Zukin, S. Loft living : culture and capital in urban change.59 
advancement and architectural innovation of the Industrial revolution era with their cast-iron technology managed to escape destruction. From its humble beginnings as an initiative taken by artists seeking cheap and large living spaces, to it becoming a booming phenomenon having an appealing economic status, warehouse living became a phenomenon, which though initiated in New York's former Industrial quarters, soon spread to further regions and abroad.

\title{
Conclusion
}

SoHo became known throughout the world as an art centre of unusual vitality, filled with trendy galleries, fashionable boutiques and restaurants, artist's studios, and loft apartments. Few people remember that for much of the twentieth century, SoHo had been a warehouse and manufacturing district. When it was designated a historic district, the area was known for its dirty, half empty buildings. ${ }^{65}$

\begin{abstract}
Since Soho's name conjures up images of large loft apartments, many real estate developers outside of New York have put the name on their projects. They believe that prospective condominium apartment buyers will believe that their homes are large and spacious, just like in New York's Soho neighborhood. They also believe it's an effective marketing vehicle to convince buyers that a 'Soho loft' development will attract sophisticated, fashion-conscious people to their condo projects. ${ }^{66}$
\end{abstract}

Throughout this thesis the notion of 'loft-living', a term coined to represent living in a warehouse or factory converted apartment will be referred to in local Wellington case studies. The idea of loft-living became a global term used to advertise apartments by property developers and referred to in prospectus' due its global evolution as a fashionable mode of living. What started as a marginal movement in one area of New York purely out of necessity, soon evolved into a popular cultural, political and architectural phenomenon, transforming and gentrifying not only the buildings themselves but the neighbourhoods around them, bringing life back through their rejuvenation. 
The four Wellington case studies analysed in the next chapters, were chosen because they were diverse examples of former factory and warehouse buildings that had been converted into residential apartments. They were diverse both in terms of location, history, former use, the political and social context surrounding them, as well as the architectural and aesthetic approaches used in their conversions. The earliest example and the last, were chosen to see the changes that may have occurred in the conversion approaches throughout the decade. The Hannah Factory was chosen because it was the first recorded converted factory apartment in Wellington.

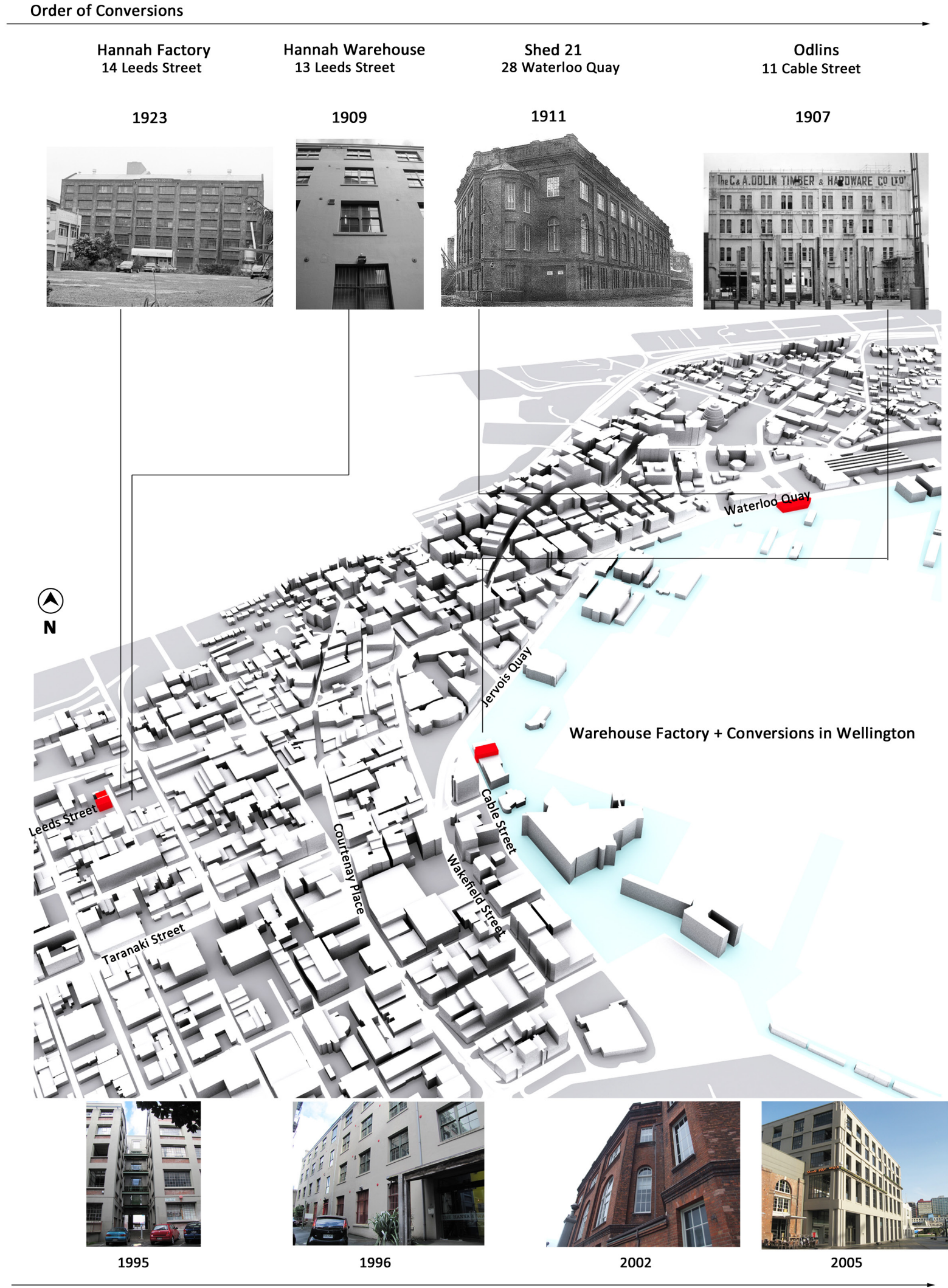

Fig 20. Locations of case study warehouses and factory buildings analysed in this thesis. Images show the original construction date and the date the buildings were converted into living spaces. 


\section{Summary Table}

\begin{tabular}{|c|c|c|c|c|}
\hline & Shed 21 & Odlin's & Hannah Factory & Hannah Warehouse \\
\hline Location & 28 Waterloo Quay, Pipitea, Wellington & 11 Cable Street, Wellington & 14 Leeds Street, Te Aro & 13 Leeds Street, Te Aro \\
\hline Classification & $\begin{array}{l}\text { Category } 1 \text { Historic registration by the } \\
\text { Historic Places Act } 1980 \text { on } 18^{\text {th }} \text { March, } \\
1982 \text {. }\end{array}$ & $\begin{array}{l}\text { Category } 1 \text { Historic registra- } \\
\text { tion by the Historic Places } \\
\text { Act }\end{array}$ & No Classification & No Classification \\
\hline $\begin{array}{l}\text { Year of construc- } \\
\text { tion }\end{array}$ & 1911 & 1907 & 1923 & 1909 \\
\hline Year of conversion & 2002 & 2005 & 1996 & 1995 \\
\hline Developer & Newcrest Holdings Ltd & Willis Bond & $\begin{array}{l}\text { What's New Ltd (lan Cas- } \\
\text { sels) }\end{array}$ & Private investors \\
\hline Architect & Athfield Architects & Athfield Architects & Athfield Architects & John Gray, Gus Watt \\
\hline Former use & Wool warehouse and show room & $\begin{array}{l}\text { Timber and Hardware fac- } \\
\text { tory }\end{array}$ & Shoe factory & Shoe warehouse \\
\hline New use & Apartment, offices, retail & Offices, retail, apartments & Apartments, retail & Apartments, offices \\
\hline $\begin{array}{l}\text { Number of apart- } \\
\text { ments }\end{array}$ & 43 & 7 & 24 & 14 \\
\hline $\begin{array}{l}\text { Average area of } \\
\text { two bedroom } \\
\text { apartment Number } \\
\text { of levels }\end{array}$ & $\begin{array}{l}118 \mathrm{~m}^{2} \\
2 \text { levels }\end{array}$ & $\begin{array}{l}\text { excess of } 200 \mathrm{~m}^{2} \\
2 \text { levels }\end{array}$ & 2 levels & $\begin{array}{l}96.45 \mathrm{~m}^{2} \\
3 \text { levels }\end{array}$ \\
\hline $\begin{array}{l}\text { Apartment floor to } \\
\text { ceiling height }\end{array}$ & $6400 \mathrm{~mm}$ & $7500 \mathrm{~mm}$ & $7800 \mathrm{~mm}$ & $7500 \mathrm{~mm}$ \\
\hline $\begin{array}{l}\text { Number of Car- } \\
\text { parks }\end{array}$ & 1 per resident & 2 per resident & none & $\begin{array}{l}26 \text { internal garages }+ \text { car } \\
\text { parks outside }\end{array}$ \\
\hline $\begin{array}{l}\text { Price per Apart- } \\
\text { ment } \\
\text { Excluding rates }\end{array}$ & $\begin{array}{l}\$ 545,000(\text { Feb 2011) })^{1} 2 \text { bdrms, also de- } \\
\text { pending on direction and view }\end{array}$ & $\$ 1.3$ million tender & $\begin{array}{l}\$ 273,000 \text { average } 2 \text { bed- } \\
\text { room }^{2}\end{array}$ & $\begin{array}{l}\text { Unit } 13-\$ 268,000 \text {. } \\
\text { - Unit } 10,(2 \text { bdrms on } \\
1 \text { level) }-\$ 288,00 \\
\text { Unit } 5,(2 \text { bdrms and } \\
\text { box/bay windows } \\
\text { on the west side) } \\
\$ 298,000 .\end{array}$ \\
\hline Price of Renovation & $\$ 20,000,000$ & & & $\$ 6,000,000$ \\
\hline $\begin{array}{l}\text { Existing Construc- } \\
\text { tion Materials }\end{array}$ & $\begin{array}{l}\text { Piled foundations, riveted steel columns } \\
\text { and beams, girders, steel roof trusses, } \\
\text { reinforced poured concrete floor, brick } \\
\text { perimeter walls, skylights in top floor, } 12 \\
\text { bays, load bearing brick walls }\end{array}$ & $\begin{array}{l}\text { Largely Australian Hard- } \\
\text { wood, Ironbark piles rein- } \\
\text { forced with railway iron, } \\
\text { and Oregon Pine, timber } \\
\text { floor,timber and steel mul- } \\
\text { lions trusse, posts and } \\
\text { floors, plastered brick ex- } \\
\text { terior walls }\end{array}$ & $\begin{array}{l}\text { steel columns and beams } \\
\text { supporting timber floors, } \\
\text { exterior concrete walls } \\
\text { faced with brick laid in Eng- } \\
\text { lish bond. Internal timbers } \\
\text { used for partitions, floor- } \\
\text { ing, and roof trusses were } \\
\text { heart jarrah, Oregon, rimu, } \\
\text { matai and totara. }\end{array}$ & $\begin{array}{l}\text { Cast iron columns, steel } \\
\text { beams and rolled steel } \\
\text { joists, Oregon timber } \\
\text { roof trusses spanning } 16 \\
\text { metres, plastered brick } \\
\text { exterior walls with a con- } \\
\text { crete bond beam running } \\
\text { across, corrugated iron for } \\
\text { the roofing, Matai timber } \\
\text { floors and timber window } \\
\text { frames. }\end{array}$ \\
\hline $\begin{array}{l}\text { Structural Upgrade } \\
\text { and new Materials }\end{array}$ & $\begin{array}{l}\text { Block wall between apartments, con- } \\
\text { crete shear wall (structural) between } \\
\text { apartments }\end{array}$ & $\begin{array}{l}\text { Concrete moment resisting } \\
\text { perimeter frames inserted, } \\
\text { steel columns, new con- } \\
\text { crete floor slabs laid over } \\
\text { the top of original timber, } \\
\text { new beams }\end{array}$ & $\begin{array}{l}\text { Large concrete block walls } \\
\text { inserted down the middle } \\
\text { of the building, 190mm } \\
\text { intertenancy reinforced } \\
\text { concrete filled block walls, } \\
\text { concrete bond beam in- } \\
\text { serted at each level with } \\
\text { steel floor beams anchored } \\
\text { to this. concrete overlay on } \\
\text { two existing timber floor } \\
\text { levels, steel cross bracing } \\
\text { to underside of other tim- } \\
\text { ber floors. }\end{array}$ & $\begin{array}{l}\text { Perimeter SHS steel cage } \\
\text { around building. Existing } \\
\text { columns on every bay had } \\
\text { new beams inserted to } \\
\text { run across, SHS cross brac- } \\
\text { ing to ceiling and walls, } \\
300 \times 50 \text { bearers bolted to } \\
\text { brick grids, } 250 \mathrm{~mm} \text { UB at } \\
\text { parking level, } 200 \text { PFC in- } \\
\text { serted at L1 to truss level. } \\
\text { Thickening to slabs. GIB } \\
\text { shear walls. }\end{array}$ \\
\hline $\begin{array}{l}\text { Layout of apart- } \\
\text { ments }\end{array}$ & $\begin{array}{l}\text { Two levels with bedrooms on the mez- } \\
\text { zanine level }\end{array}$ & $\begin{array}{l}\text { Two levels with bedrooms } \\
\text { on the upper level all sepa- } \\
\text { rated and walled off. }\end{array}$ & $\begin{array}{l}\text { Generally, living space on } \\
\text { the lower area with bed- } \\
\text { rooms on the mezzanine } \\
\text { level }\end{array}$ & $\begin{array}{l}\text { Single and three level } \\
\text { apartments with living } \\
\text { room generally at the top } \\
\text { level }\end{array}$ \\
\hline
\end{tabular}


The former Shed 21 warehouse and C. \& A. Odlin's Timber and Hardware Co. factory and warehouse buildings, were located on the Wellington waterfront and played an important role in the shipping and warehousing industry. Completed in 1911, Shed 21 was used as a warehouse to store wool for shipping nationally and internationally, as well as providing the venues for the 1911 Wellington Industrial Exhibition. ${ }^{1}$ The 1907, C. \& A. Odlin Timber and Hardware Co., factory and warehouse was used for the retail and manufacturing of timber and hardware. Hannah's Warehouse and Factory were located in the inner city, a different environment from the waterfront examples. Situated in the former industrial Te Aro area, these buildings were used to manufacture and store boots. Their architectural style was plainer and had a utilitarian character as opposed to the more embellished waterfront examples,

The buildings derive their character from their industrial warehousing environment. They are simple, strong and similar in scale to their surroundings. Their materials and colours grow out of the neighbouring building fabric. ${ }^{2}$

These four examples of former warehouse and factory buildings, later converted into residential apartments, vary in their original programme, age and time of conversion as well as their eventual architectural outcome. These examples aim to show the parallels and similarities of converted apartments in Wellington and the different approaches taken by those involved with their reuse.

\section{Containerisation}

Shed 21 and the Odlin's Building were warehouses situated on the waterfront which became obsolete and vacant due to the change over to containerisation. Containers were first introduced to Wellington by the Railways Department in 1952 for rail-air freight. Easily transferred between truck, railway wagon, aircraft and ship, containers speeded up loading and unloading, and reduced pilfering, damage and costs. Land reclamation was carried out on both sides of Queens Wharf and, most significantly, the container terminal was created by a large reclamation at Thorndon. The first container ship berthed on 19 June $1971 .^{3}$

In the early 1990s, the inner city Hannah Factory and Hannah Warehouse became derelict when the Robert Hannah \& Co. boot empire relocated to other cities and stopped manufacturing and storing goods in these buildings premises. $^{4}$

\footnotetext{
1 Dave Pearson Architects Ltd, Shed 21 Assessment of Effects, prepared for Newcrest Holdings Ltd.

$2 \quad$ Niven, S., If the Shoe Fits, ANZ November/December 1989.35

$3 \quad$ Wellington Waterfront Framework. Web. 5 May 2011

$4 \quad$ Victoria Quade, personal interview. 27 Sept 2011
}

\section{Zoning Changes}

A significant aspect that played an important role in allowing these building to be changed reused for residential purposes, was due to the changes that occurred in zoning regulations, allowing former industrial and commercial areas to house residential activities.

In Wellington, prior to 1994, residential living in industrial and commercial zoned areas was largely prohibited. Under the Resource Management Act and the new District Plan introduced 1994, any activity whether it be commercial, manufacturing, or residential was permitted in Te Aro (apart from some noxious or dangerous uses) under Rule 13.1.1, Chapter 13 of the Wellington District Plan. "This liberalisation opened the way for the conversion of warehouse/commercial buildings to residential and the construction of new apartment blocks." ${ }^{5}$ Some activities were more acceptable than others. The general public was allowed to propose different uses. The Wellington City Council's removal of impediments and general liberalisation, thus opened the way for the conversion of old warehouse, factory and commercial buildings into residential ones. ${ }^{6}$

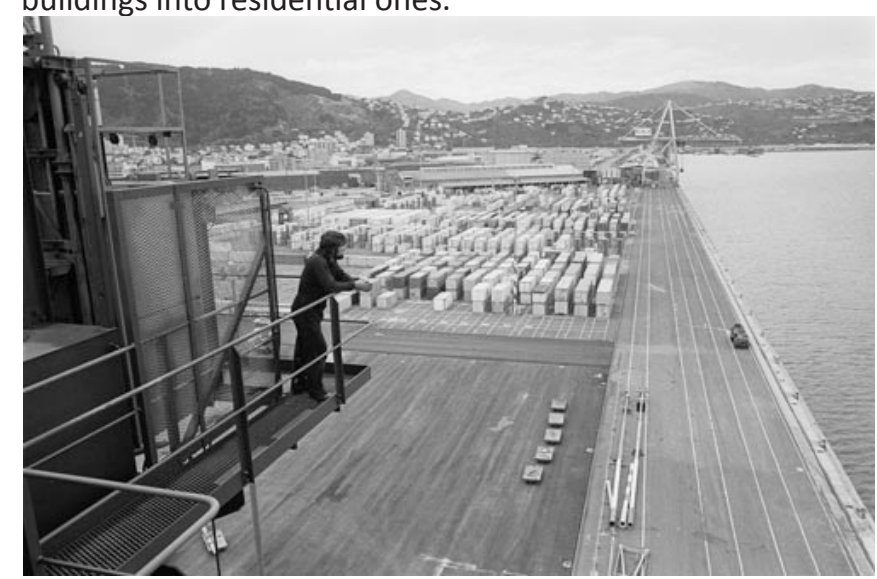

Fig 21. Wellington Container port

In 2000, with the introduction of the Wellington District Plan operative, zoning was introduced under a flexible approach which allowed any activity to be located anywhere. ${ }^{7}$

Factors that lead to rezoning included the recession that hit New Zealand and the need for restructuring. Corporate offices moved to Auckland, Australia and Asia, and the city ceased to be the national centre for banking. ${ }^{8}$ The motor manufacturing industry had also closed its plants in the Wellington region. The rapid increase in population was another factor that resulted in the zoning change from

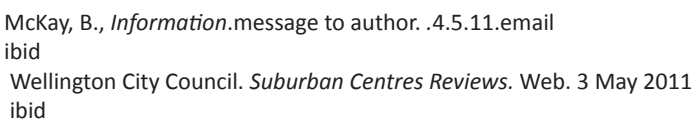




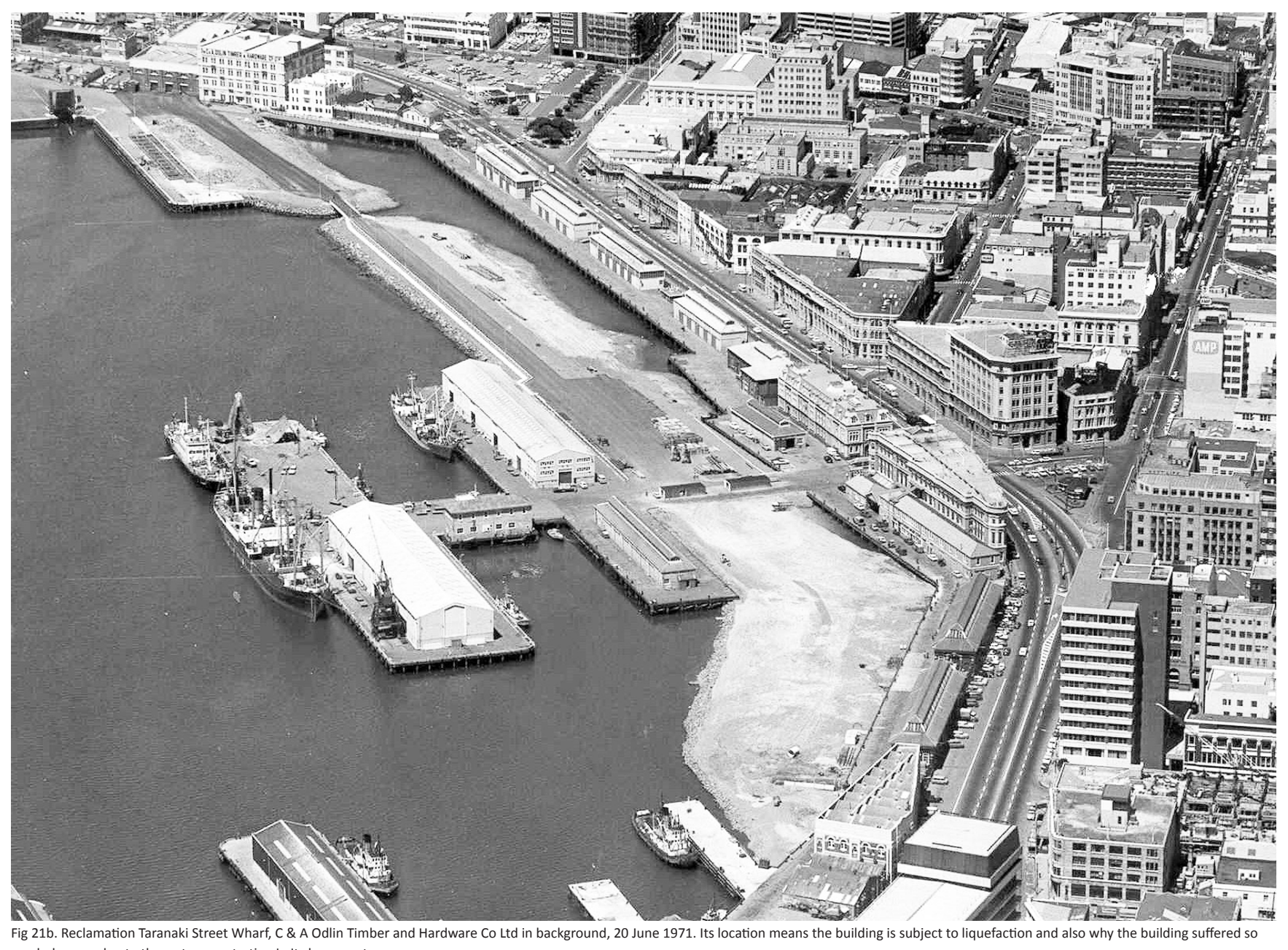

Fig 21b. Reclamation Taranaki Street Wharf, C \& A Odlin Timber and Hardware Co Ltd in background, 20 June 1971. Its location means the building is subject to liquefaction and also why the building suffered so much damage due to the water penetration in its basement area.

Industrial areas to permit residential use. ${ }^{9}$

During the mid 1990s, the ratio of car parks to the size of the building was also removed, and this explains why some conversions in the following chapters did not have to provide car parks to tenants. ${ }^{10}$

With the decline of business in Wellington's warehousing areas, these buildings now stood obsolete, however many possessed a heritage classification, therefore simply demolishing them was not an option. The solution was to reuse these buildings for residential purposes. The Wellington City Council stated that the purpose of rezoning an area was to "rezone the land to better reflect land use of that area."11

The changes that occurred due to rezoning and allowing residential conversions became evident in the city's

\begin{tabular}{ll}
\hline 9 & ibid \\
10 & ibid \\
11 & ibid
\end{tabular}

relationship with the sea as the latter was transformed from a former industrial centre into a pedestrian friendly area. Each of the converted former Wellington warehouse and factory buildings examined in this thesis had a rich history in shaping the events of Wellington, and the social and political development occurring in Wellington over the decades. To demolish them would have been to end this legacy. Each case study will evaluate their successful adaptation and reuse, through a change of programme and an architectural upgrade.

Sometimes the mark of a successful project is the tension between the expected use, i.e. what the building conveys, and a completely different, new function that has been cleverly fitted into it... the existing building structure should [however] inform the future use of the building, and not vice versa. ${ }^{12}$ Breitling, S., and J Cramer, Architecture in Existing Fabric 102 
The analysis of four former Wellington warehouse and factory case studies will assess the benefits of their conversion into apartments, including the rejuvenation of derelict areas, and the emergence of a movement that fostered the recognition of a city's architectural heritage and value of its preservation. 


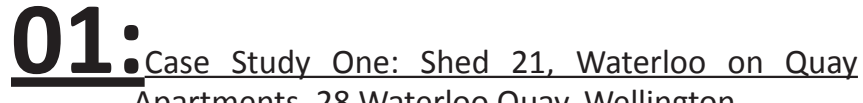 Apartments, 28 Waterloo Quay, Wellington}

Historic buildings and sites are finite, linking us to the past and our cultures, as well as enhancing the environment by providing diversity. ${ }^{1}$

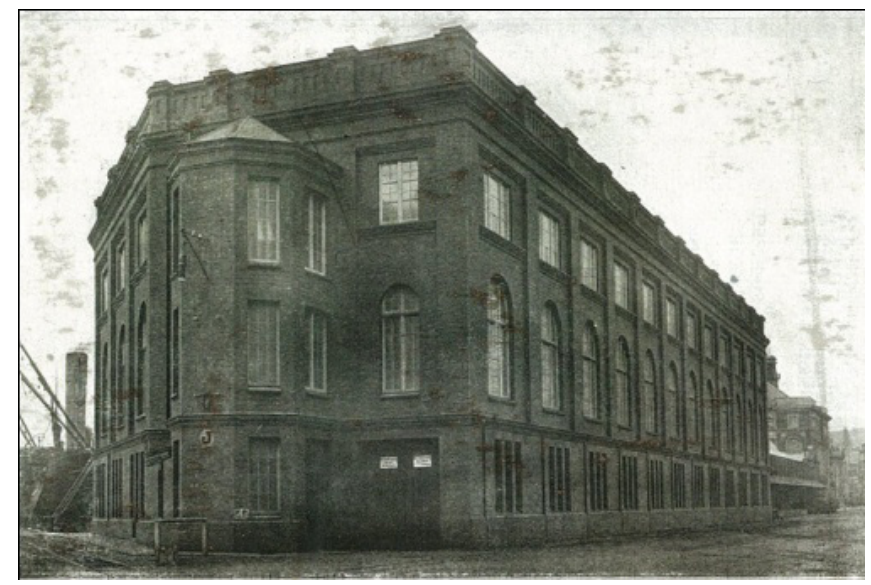

Fig 22. Wool Store circa 1911

This Chapter evaluates and analyses a former Wellington wool shed warehouse. In 2000, it was converted into 43 apartments and retail space by Athfield Architects. It discusses the building's significant mark on the waterfront, its former use and the changes that were implemented when it was converted into residential apartments. The chapter investigates how the building's historic assessment and classification ${ }^{2}$ impacted on the modification and architectural alterations of the original, and what interventions were necessary to readapt the building for a new use.

Holman,.S "Finding Funds for Heritage". New Zealand Historic Places. No 68. May 1998. 26-28

$2 \quad$ New Zealand Historic Places Trust. Wellington Harbour Board Shed 21 'Waterloo Quay, Wellington'. Web. 8 May 2011.

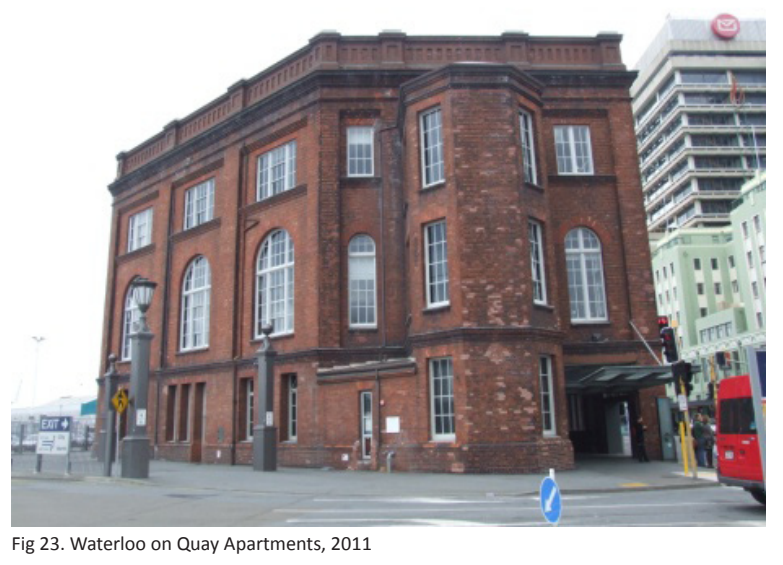

Fig 23. Waterloo on Quay Apartments, 2011 
Timeline

\begin{tabular}{llll}
\hline 1909 & 1911 & 1911 & 1950 s \\
$\begin{array}{l}\text { Old timber warehouse } \\
\text { destroyed }\end{array}$ & $\begin{array}{l}\text { Shed } 21 \text { completed } \\
\text { for } 23,596 \text { pounds. } \\
\text { Designed by James }\end{array}$ & $\begin{array}{l}\text { Industrial Exhibition } \\
\text { held in Shed } 21\end{array}$ & $\begin{array}{l}\text { Due to Containerisation building } \\
\text { became redundant }\end{array}$ \\
\hline
\end{tabular}

1989

First local Government Amendment Act dissolved the Harbour Board property assets. WCC gained ownership

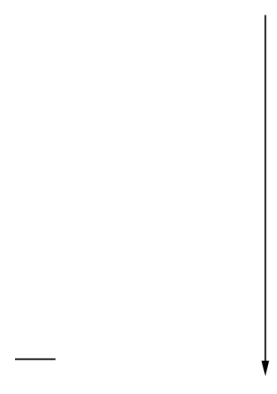

1990s

Largely derelict, used as a carpark

2002

Conversion into Apartments completed by Athfield Architects

$$
\uparrow
$$

2000

Lambton Harbour Management awards Auckland company Newcrest Holdings the contract for redevelopment into apartments

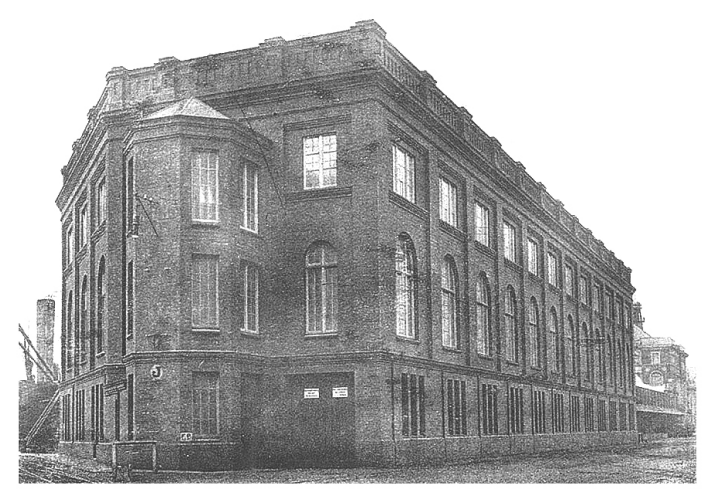

1999

Proposals are sought for redevelopment opportunities

Fig 24. Shed 21, historic events 


\section{History}

A former wool store and warehouse, Shed 21 was built in 1911 for $£ 23,596$. It was designed by Wellington Harbour Boards Chief Engineer, James Marchbanks in a Bostoninspired Edwardian style. A comparison has been made to the Chicago, Marshall Field Warehouse (Fig 2) ${ }^{3}$. Similarity between the two warehouses can be seen in their massive load bearing walls, carefully grouped window openings with semicircular arched windows, as well as other stylistic and structural parallels. Both structures emphasized function and "de-emphasized the need for extravagant geometric shapes or ornate decoration" 4 .

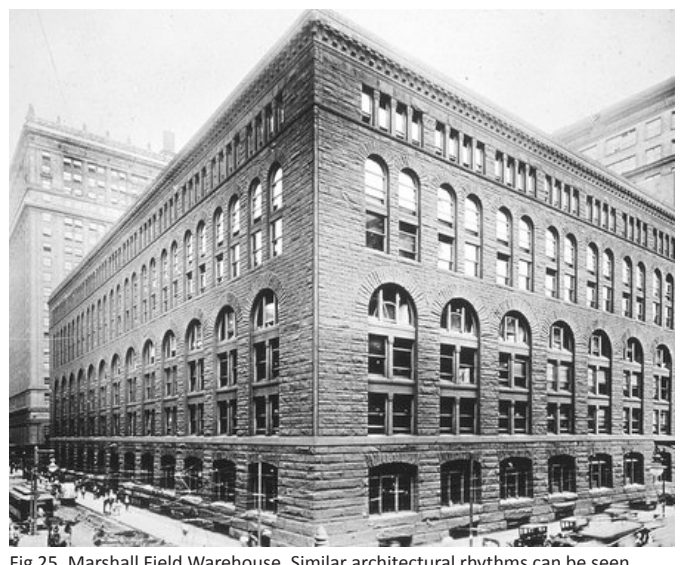

Shed 21 replaced the old timber J Shed warehouse constructed in 1882 by the Wellington Harbour Board which had burnt down in the fire of $1909 .{ }^{5}$ Its prominent location on the Waterloo Quay wharf and its advanced technological structure granted the building a Category 1 Historic Classification by the Historic Places Act on $18^{\text {th }}$ March, $1982 .{ }^{6}$ The building was one of 15 heritage structures on the Lambton Harbour Precinct alone. Others included the Herd St Post \& Telegraph Building on Chaffers Marina, Museum of Wellington City and Sea, Wellington Free Ambulance Building, Shed 22 and the former C \& A Odlin's Timber and Hardware Co. The latter was also redeveloped into apartments and offices in 2005 and forms another case study in this thesis.

In the late 1970s and 1980s, the shift from cargo handling on wharves to container ports occurred in Wellington. This affected the former warehouses situated along the wharf, leaving them vacant and deserted; devoid of the bustling

\footnotetext{
3 Dave Pearson Architects Ltd, Shed 21 Assessment of Effects, prepared for Newcrest Holdings Ltd.

$4 \quad$ Form and Function. Web. 8 Apr 2011

$5 \quad$ Wilson, T, and M. Kelly, Maritime Heritage Trail. Web. 8 Apr 2011

$6 \quad$ New Zealand Historic Places Trust. Wellington Harbour Board Shed 21

'Waterloo Quay, Wellington'. Web. 8 May 2011.
}

activity they once accommodated. This was particularly evident in the area from Queens Wharf to the International Terminal, ${ }^{7}$ (with several former warehouses having since been reused for other purposes.) In the 1990s, Shed 21 was partly used for conservation work on the remains of the ship Inconstant and as a car park ${ }^{8}$ until the first Local Government Amendment Act dissolved the Harbour Board property assets and the ownership of Shed 21 fell to the Wellington City Council (WCC), and its management to Lambton Harbour Management Ltd.

Shed 21 was one of the few examples of a warehouse building still standing in its entirety in Wellington, as its structure remained intact and without modification until its conversion.

\section{Existing Construction and Materials}

The warehouse's features were revolutionary for the time, aiding the work on the wharfs. Its function was to store wool prior to shipping both locally and further abroad. Up until the construction of Shed 21, wool was delivered to wharves by horse drawn wagon and train. Bales had to be weighed, marked, dumped and stacked ready for shipment, requiring a large supply of labour.

The new wool store greatly sped up the process through its use of rail tracks and sidings on the west side, which allowed for wool to be directly discharged by rail and stored. Sky lighting in the top glass gallery level effectively illuminated the exhibition area for the sale of the wool, and this space was used for the Industrial Exhibition in 1911. ${ }^{9}$ Three cargo hatchways allowed the bales to be hoisted hydraulically up to this floor, this was another technologically advanced mechanism for its time within the wool store. ${ }^{10}$ Accumulated water pressure was used to drive lifts that moved goods between floors. Hydraulic power was once the main source of power on the waterfront and was still used for wool presses, cranes and other equipment until finally superseded by electricity in the 1950 s. $^{11}$

In architectural terms, the characteristic elements are refined to provide a building that clearly states its function. The materials were rather revolutionary for the time, for unlike other Wellington warehouses constructed with hardwood posts and beams, Shed 21 was constructed with concrete, steel and brick. The brick load bearing external walls were

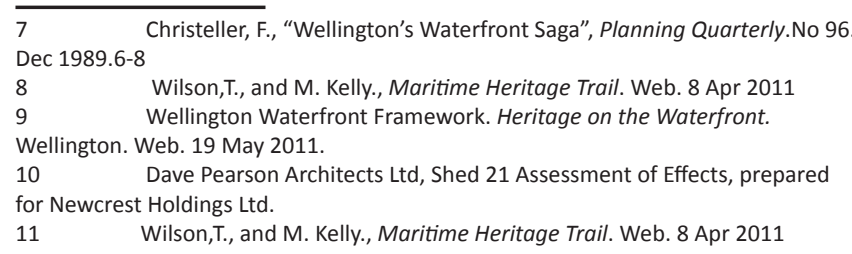




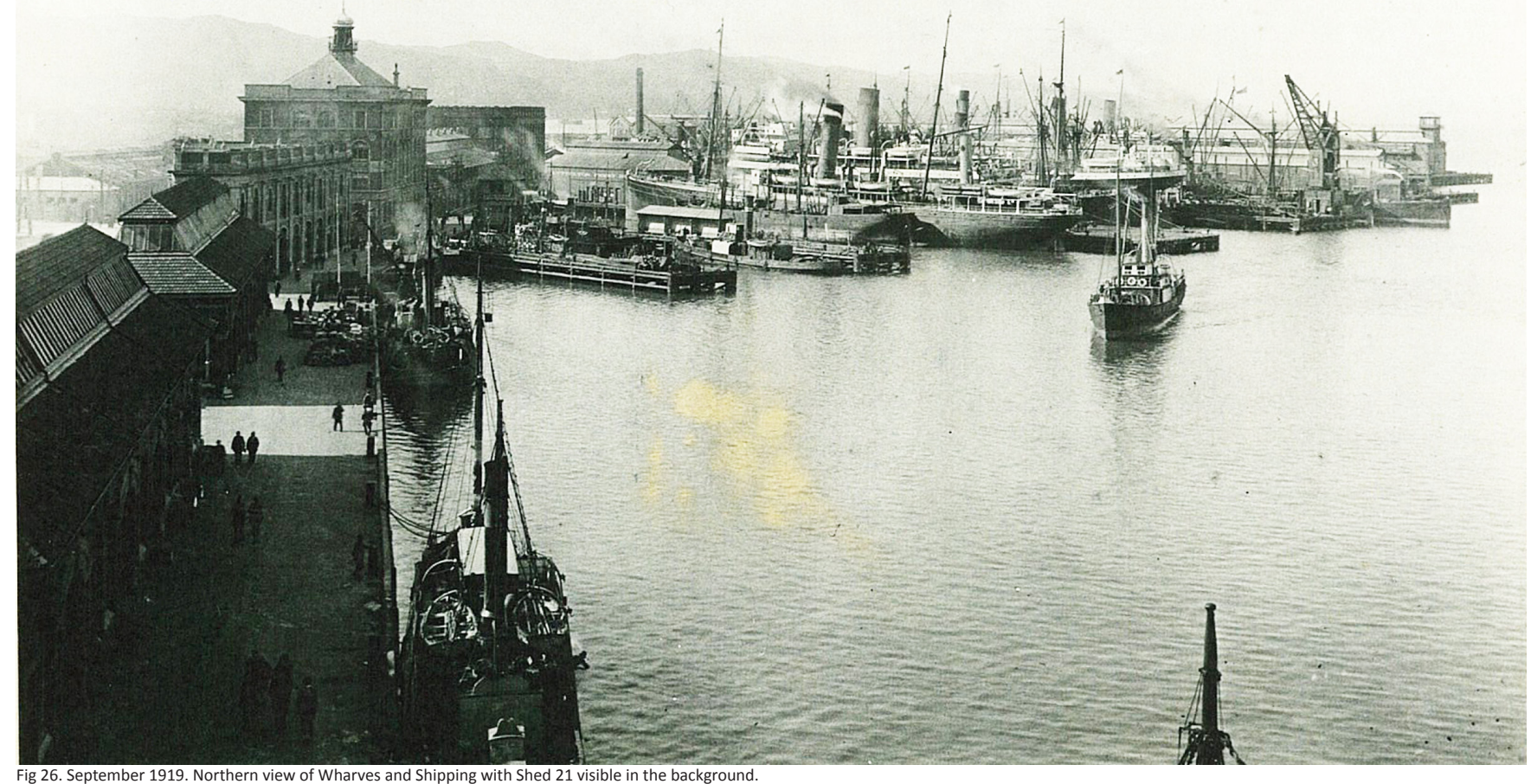

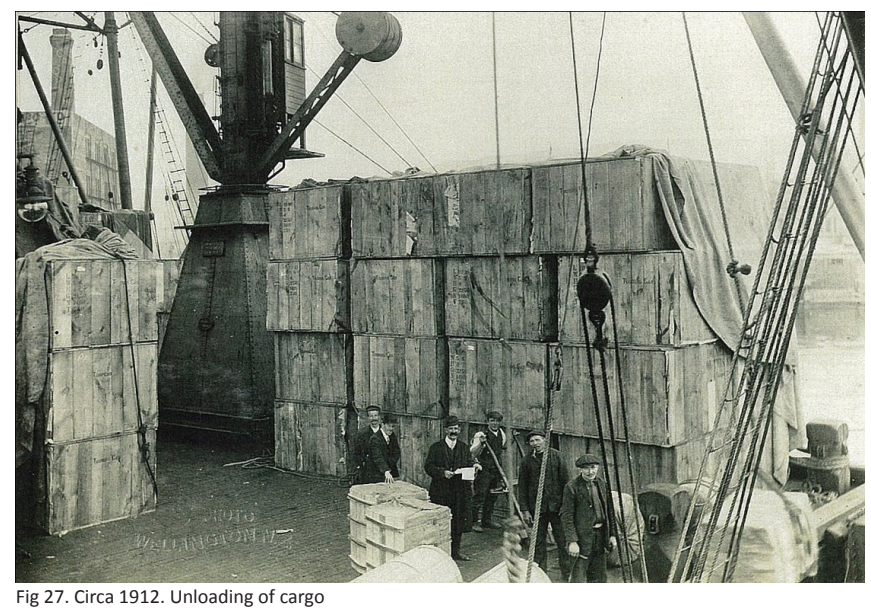

laid in English bond, with an internal framework of steel columns supporting girders for streamlining wool loading activities by incorporating rail traffic into the design of the building. The floors were poured concrete. Piled foundations supported steel columns and girders riveted on site. The wide span steel trusses and the riveted steel columns provided an advantage over other contemporary wool stores which were restricted in their span widths due to the limitations of timber construction. ${ }^{12}$ The steel columns and beams were shipped out from England to be used in place of traditional hardwoods. $^{13}$

Light penetrated into the top level through glass skylights. The twelve structural bays emphasised the warehouse's rigid rectangular layout, clearly emphasising the functionality in the design. Upon conversion this existing structural layout was the basis for the layout of the apartments, and the existing glass gallery space was maintained to give an extra source of internal light in the otherwise light free corridors between the apartments.

Other distinguishing features included the large, arch headed windows in the middle storey which were set in kauri frames and the brick facade which embellished an otherwise plain functional facade. The northern end tower gave the building 12 Dave Pearson Architects Ltd, Shed 21 Assessment of Effects, prepared for Newcrest Holdings Ltd.

13 Athfield Architects, Waterloo on Quay Apartments (Shed 21). Wellington. C 2002. CD 

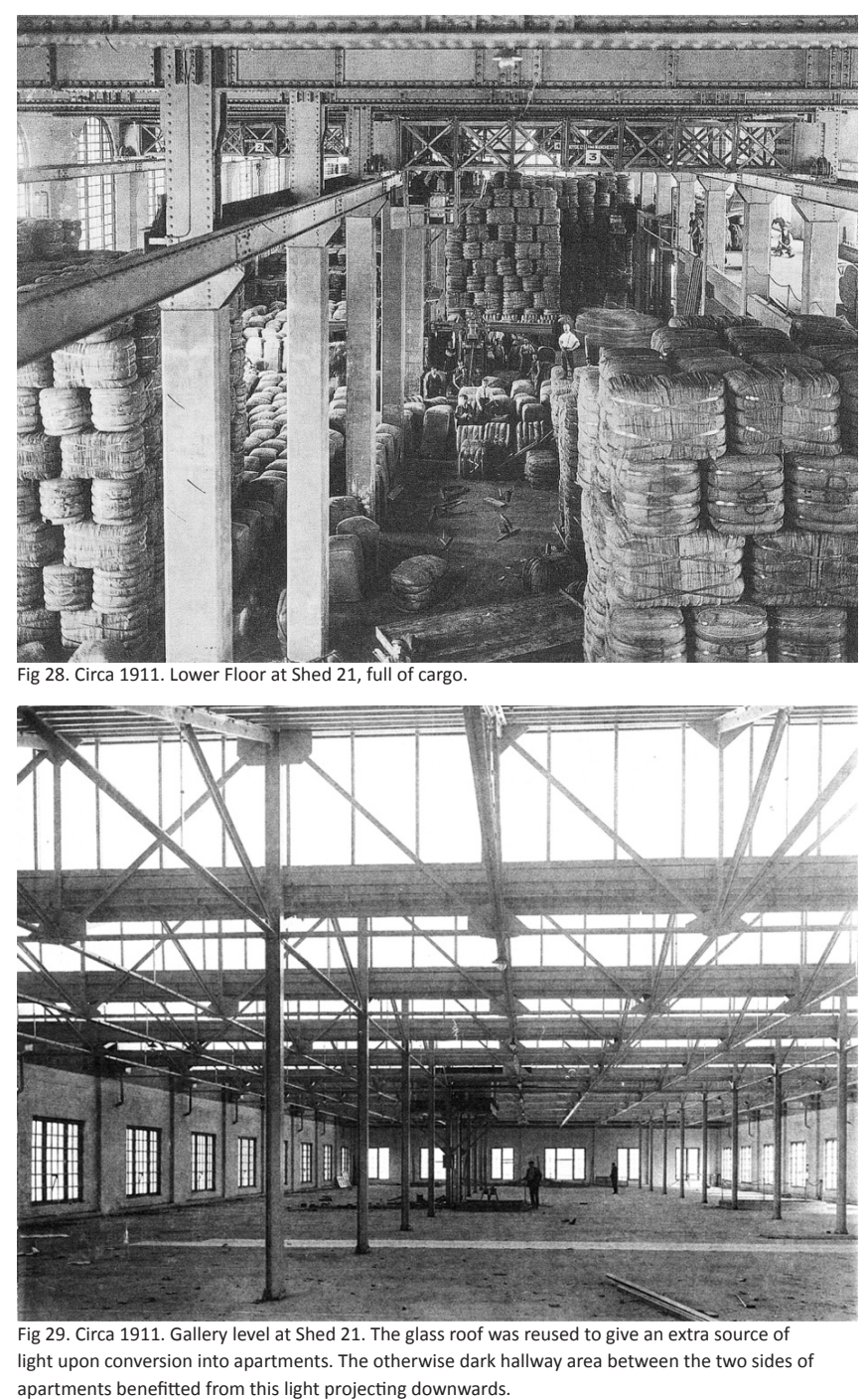

a faintly ecclesiastical look which it has been suggested, was due to the influence of Frederick de Jersey Clere, a prominent architect who had designed several brick churches around Wellington as well as the Wellington Harbour Board Head Office and Bond Store. ${ }^{14}$

This tower housed a large wool press, powered by a hydraulic accumulator, which was used as a lifting mechanism. Accumulated water pressure was used to drive lifts to move shipping goods between floors. Shed 21's other noted features included a cart dock, three cargo hatchways that enabled bales to be hoisted up to the wool sales area, a railway track, and wide doorways. ${ }^{15}$ One of the greatest innovations in this building was its use of a steel structure exposed throughout the interior.

\footnotetext{
14 Rogers., I., 'A Waterfront Heritage'. Historic Places. 46

15 Dave Pearson Architects Ltd, Shed 21 Assessment of Effects, prepared for Newcrest Holdings Ltd.
}

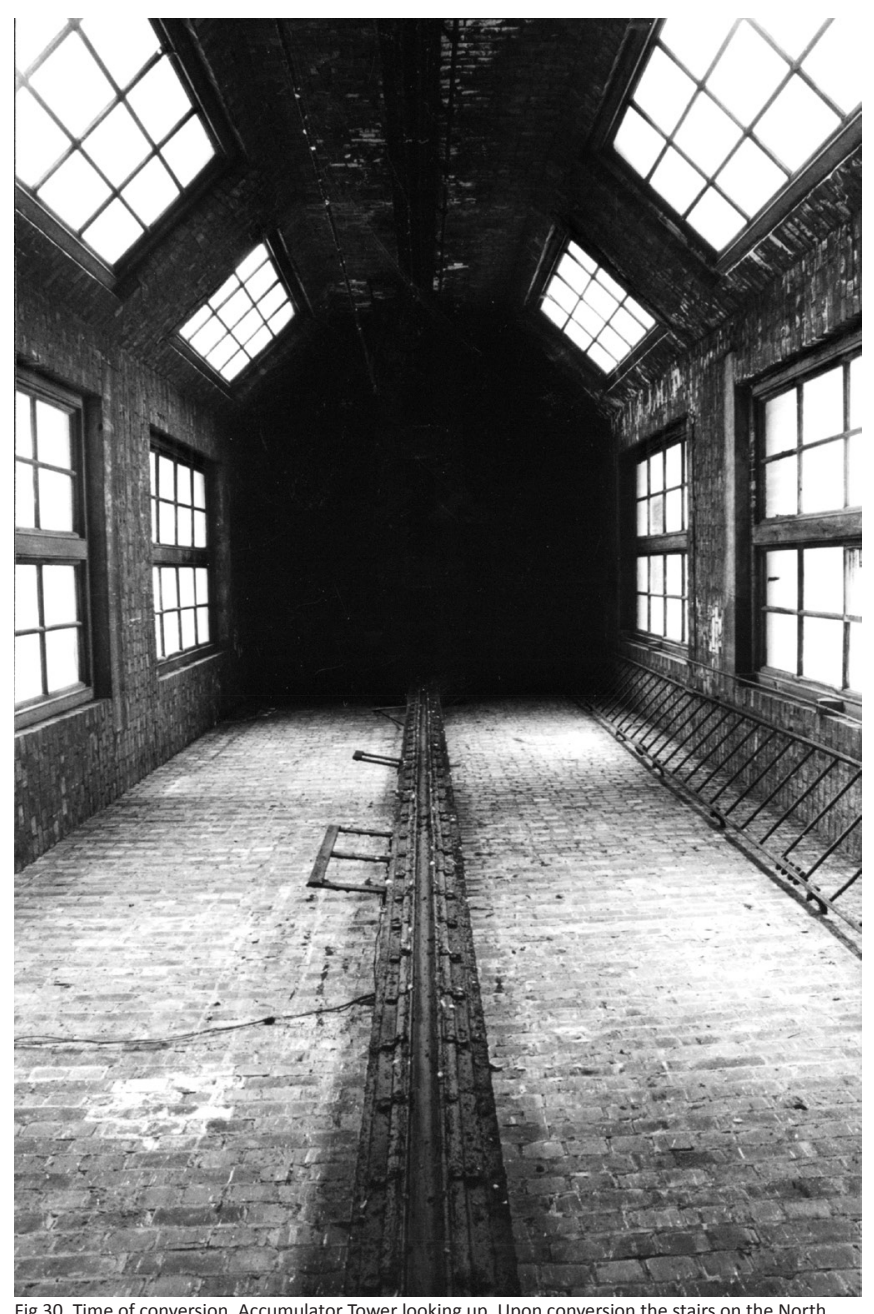

Fig 30. Time of conversion. Accumulator Tower looking up. Upon conversion the stairs on the North side were built around this feature. The existing steel and timber beams running vertically up the Accumulator wall were also retained.

\section{Conversion}

The building's rich waterfront history and existing programme gave a unique character to the building. Traces of the past purposes were retained when the re-use of the building as apartments was proposed. The bare material that was left exposed and raw and the new additions were in keeping with its style. Legislative rules regarding height restrictions in this central area also meant that the warehouse could not have any roof additions, keeping the building's envelope in its original state.

\section{Historic Assessment}

Prior to conversion, Dave Pearson Architects Ltd. carried out a historic assessment of the individual building's features for Newcrest Holdings Ltd property developers. This report evaluated which features should be considered for demolition, restoration, modification and/or preservation. 
The historical values of the building's elements and separate areas are given in the following table, where $\mathbf{A}$ represents Exceptional Value, B represents Considerable Value; C represents Some Value and D is No value.

\begin{tabular}{|c|c|}
\hline Exterior facade General & A \\
\hline Semicircular arched fixed sash windows & A \\
\hline Rectangular Fixed Sash windows & B \\
\hline Set of 3 rectangular 8 light fixed sash windows & B \\
\hline Vertical T\&G ledged and braced sliding doors and roller mechanism & $\mathrm{C}$ \\
\hline Brick Parapet & B \\
\hline Bricked in door openings & $\mathrm{D}$ \\
\hline Early external lighting elements & $\mathrm{C}$ \\
\hline Recent external lighting elements & $\mathrm{D}$ \\
\hline Roof & A \\
\hline South facing skylights, including fine obscure glazing & A \\
\hline Accumulator tower & A \\
\hline \multicolumn{2}{|l|}{ Interior Spaces and features } \\
\hline Ground floor space & A \\
\hline Toilets and storage & $\mathrm{D}$ \\
\hline Steel columns, girders and beams & A \\
\hline Concrete encasing to columns & $\mathrm{D}$ \\
\hline Concrete floor & B \\
\hline $1 \frac{1}{2}$ ton Royce electric crane and gantry & A \\
\hline Railway siding & B \\
\hline Steel window guards & $\mathrm{C}$ \\
\hline Gallery stairs & C \\
\hline Gallery floors & B \\
\hline Top Floor space & B \\
\hline Wool bale hatches & B \\
\hline Bale hoist & B \\
\hline Steel roof trusses & B \\
\hline South facing skylights & A \\
\hline Concrete floor & B \\
\hline Window guards & $\mathrm{C}$ \\
\hline
\end{tabular}

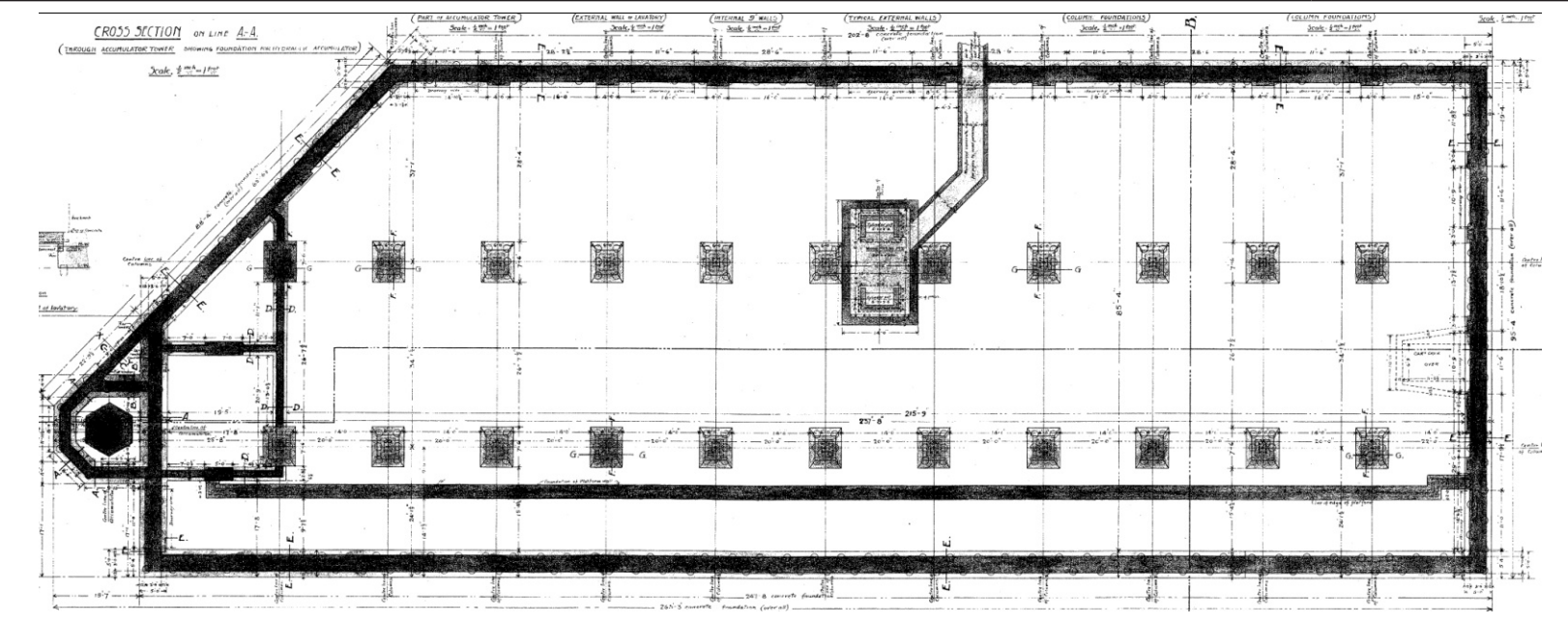

Fig 31. Foundation Plan showing woolpress pit (central), culvert on the seaward side, cart dock on the right side, Accumulator tower on the left and railway track on the street side 40 
Upon conversion, the brickwork located on the seaward that had covered the door openings for years was restored back to its original state. The bricked up rail opening was also restored. The northern rail door was removed and the opening was returned for use by pedestrians. The new retail outlets on the ground floor were simply detailed so as not to detract from the quality of the existing building. ${ }^{16}$

Significant heritage elements within the building were treated with utmost respect. These were the two moveable items: a hoist and an electric crane. The hoist was reused in the building whilst the future of the crane and gantry was undecided at the time of the design, but it was to be preserved by the Lambton Harbour Managements if it were to be removed.

\section{Legal Changes on the Waterfront}

In September 2000 Wellington City Council appointed a Waterfront Leadership Group to consult with the public and develop a vision, values and principles for future development on the waterfront. Council adopted its recommendations in the form of the Wellington Waterfront Framework (the Framework) in April 2001, and this Framework guided what was to be done on the waterfront.

A series of themes were recognised for future development of the waterfront, and these included: historic and contemporary culture, city to water connections, a promenade, open space, diversity. The objectives also outlined the design for the waterfront to be: readily accessible to all people, perceived to be safe at all times, seen as an attractive place that would draw Wellingtonians and visitors, and significantly heritage buildings were to be protected. ${ }^{17}$

With the introduction of the Wellington District Plan operative in 2000, zoning was introduced under a flexible approach which allowed any activity to be located anywhere. One outcome of this was the comment, "Flexibility lets market trends develop, and has allowed some areas to evolve into more vibrant places." ${ }^{18}$

Permission for the conversion of Shed 21 was eventually granted for its reuse as apartments and Athfield Architects were selected to do the conversion work. The Historic Places Trust found the firm's proposed design carefully preserved as much of the existing historical building as possible. The strengthening, rebuilding and refurbishment was part of a \$20 million redevelopment taken on by Newcrest Holdings. Project manager Steve Rowe stated in an article in the

16 Dave Pearson Architects Ltd, Shed 21 Assessment of Effects, prepared for Newcrest Holdings Ltd.

17 Wellington Waterfront Framework. Heritage on the Waterfront. Wellington. Web. 16.Nov 2011.

18 Wellington City Council. Suburban Centres Review. Wellington. Web. 3 May 2011.
Business review that, "unlike the problems being experienced with new buildings this [building] was solid and designed to last...this building is already 100 years old and should be good for another 100 years." ${ }^{19}$ In 1999 it was tendered as a development option by Lambton Harbour Management as part of the waterfont redevelopment. ${ }^{20}$

\section{Modification}

Athfield Architects were selected for the redevelopment of Shed 21, because their proposal sought to preserve a number of heritage items which would add to the interpretation of the building as a former wool store. ${ }^{21}$ Because Shed 21 was part of a group of historic warehouses and buildings on the waterfront, overseen by the Wellington Council and part of the Wellington Waterfront framework, the architects and developers had a set of criteria within a framework with which they had to comply.

The proposed programme included:

- The retention of the large width of the main corridor on the apartment levels which retained the sense of spaciousness in the building;

- The addition of the mezzanine floors that were not intended to bisect the large semi circular arched windows, hence not compromising the existing design features;

- The strengthening of the area which formerly housed the accumulator tower in a very sensitive manner;

- A revised colonnade to provide pedestrian access without compromising a key facade that would run throughout the brick exterior in a similar way to the original train;

- Retention of as much fabric as possible: window joinery was to be carefully modified to allow existing windows to open;

- The use of design elements (rhythm, patterns, detail) in the building to guide changes: the door openings along the colonnade were to mirror the openings on the seaward side of the building;

- Emphasis was on the use of existing

\begin{tabular}{|c|c|}
\hline 9 & 5. 'Historic woolstore rebuilt'. The National Business Review. 27 \\
\hline & \\
\hline 20 & aterloo on Quay Apartments (Shed 21). Wellingto \\
\hline & $\begin{array}{l}\text { son Architects Ltd, Shed } 21 \text { Assessment of Effects, prepared } \\
\text { td. HPT }\end{array}$ \\
\hline
\end{tabular}



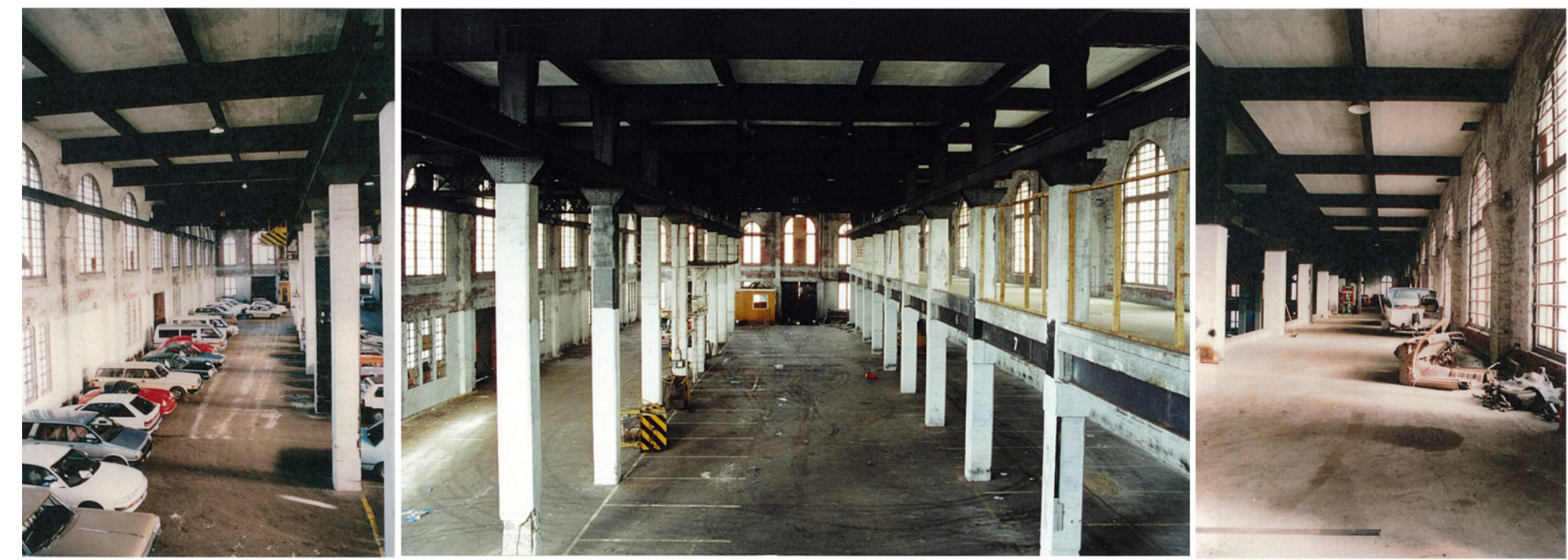

Fig 32. During the buildings dereliction it was partly used as a carpark. Photo taken by Athfield Architects circa 2000.

elements rather than introducing new ones or new materials: bricked-in door opening were to be opened up, existing south light glazing was to be reused;

- $\quad$ Revealing and recovery of lost fabric: the railway sliding was to be recovered and utilised to provide a greater understanding of how the building formerly functioned.

The concept and vision for the conversion of the former warehouse was one that took into consideration the historic nature of the building as well as its close proximity to the sea. The new spaces were designed to work alongside the existing double height ceilings and structural framework,

\begin{abstract}
The conversion of this building into apartments needed to be a unique example of an apartment development with very minimal external change and creating positive space for occupation. The scale of spaces was dictated by the existing structure and needed to be carried through into the new design. The apartments needed to provide a secure and long future for living on this threshold between the sea and the land. ${ }^{22}$
\end{abstract}

The architects approach to the conversion of this building was successful in the way they had thoroughly associated the buildings former history, use and important elements, thus formulating a restorative as wells as re-adaptive approach, without losing the buildings existing character to a certain level.

The introduction of the public walkway on the street side mirrored the original train tracks that were there. Athfield architects stated that the series of holes created on this side

$\begin{array}{ll}22 & \text { Athfield Architects, Waterloo on Quay Apartments (Shed 21). Wellington. } \\ \text { 2002. CD }\end{array}$

was about enabling interaction in the future. The architects explained their position as, anticipating the future of the building and the continuing development of the waterfront over the next 10-20 years. They expected the area to become more accessible, therefore creating this public walkway area was a result of that expectation. ${ }^{23}$

A major characteristic of the existing building which influenced the conversion process was the large double height spaces and spacing of internal columns within it. This was due to the building's existing large bay spans, constructed of concrete and steel columns as opposed to the more common timber ones in other warehouses built in the same era. Based on the building's existing structural grid, the apartments were designed as two bedroom, double height spaces with alternate designs for the corner apartments to suit the building's shape. Steve Rowe stated regarding the large volumes within the converted building, "The sort of spaces in this building-which is a private apartment buildingare normally the sort of spaces you only find in a public building." 24

The apartments that were designed in the former warehouse retained the building's industrial essence through the careful preservation and rejuvenation of existing elements. The apartments were not dissimilar to those of New York in the sense that they retained a bare industrial essence and large floor to ceiling height. Service ducts and columns were left exposed and uncovered, as were the red brick exterior and interior walls. The concrete floor had to be carpeted due to sound regulation requirements, but the aim of the project and the architect's vision was to leave the building intact. Retail and a few office spaces were incorporated into the ground level, which were to keep the building public. The garage level, with private secured entry, was inserted on the ground floor, as well as the provision of storage space.

23 Athfield. Z., and Hardwick-Smith J., Personal Interview., 11 November 2011

24 Rowe, Steve, The National Business Review. 27 Sep 2002 

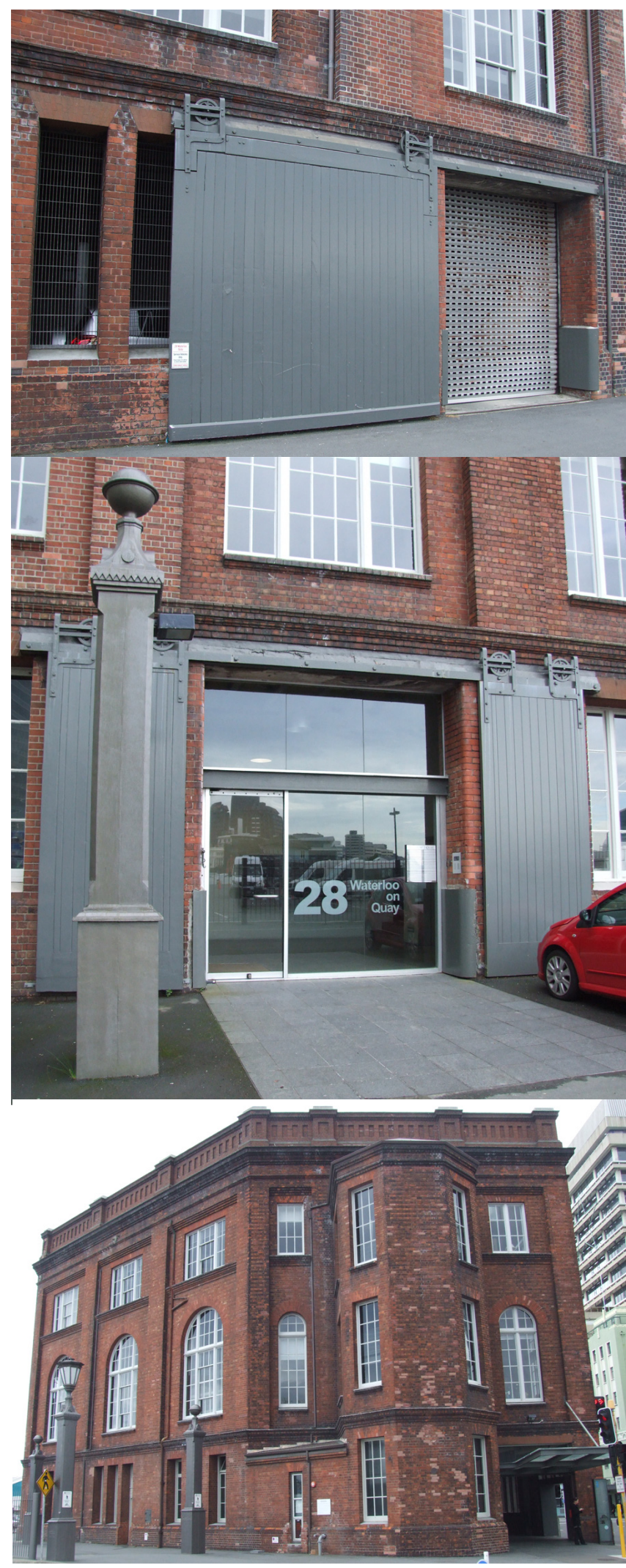

Fig 33. Original sliding doors were repaired and reused. Top image shows entrance to carpark. Middle image shows Southern entrance. Bottom entrance shows main entrance from the Northern end.
The main entrance reflected the original opening in the north end where bales of wood left the building. Being the main entrance to the converted apartments, it replicated the entrance with the heaviest use, as in the building's original existence. The other main entrance was at the opposite end, in place of the existing cart dock entry. The new ramp at the south end required ground excavation to insert the new elevator and stairs. As well as the two new stairways at the north and south ends, two fire rated lifts were added at both ends. The south end one replaced the old office. The majority of the existing sidings remained, and were used as entry points into the new car park area.

The apartment wall finishes in Shed 21 were a cement plaster sponge finish applied to exposed surfaces. Plaster finish was only applied to the exposed side of the walls. An acoustic sealant with a STC (Sound Transmission Class) rating of 55 minutes was applied to the intertenancy walls. The plaster finish application to existing concrete walls was an interesting choice. Although Shed 21 retained much of its existing characteristics, choices such as covering up the floors and walls, and applying plaster finishes to walls gave the apartments a sense of polish and a modern, clean aesthetic. The floors in the bathrooms, kitchen and laundry were uncarpeted finished timber. Some of the apartments later went on to have wooden floors throughout the spaces. ${ }^{25}$

The conversion also aimed to see the building's reuse as "... [an] energetic, purposeful and contributing building, rather than a museum piece that was a drain on public money". ${ }^{26}$ An apartment venture seemed more economically viable at the time, as the demand for housing would never crease, so rather than redeveloping the building into offices, apartments were the choice.

The conversion of this historically Classified Category 1 warehouse, worked hard to preserve the building's original framework and features, whilst incorporating a new programme. The vision statement put forth by Athfield Architects stated that,

The conversion into apartments needed to be a unique example of an apartment development with very minimal external change and creating positive space for occupation. The scale of spaces was dictated by the existing structure and needed to be carried through into the new design. The apartments needed to provide a secure and long future for living on this threshold between the sea and the land. ${ }^{27}$

25 Wale,A., Apartment 2.0, Waterloo on Quay Apartments, message to author. 23.11.11. email

26 Green, S., "Historic Building gets a lived-in look." The Evening Post, 17 July, 2001

27 Athfield Architects, Waterloo on Quay Apartments (Shed 21) Wellington. C 2002. CD 
The advertising prospectus that was used to market the redeveloped Waterloo on Quay Apartments, as Shed 21 became known, described living in them as a true privilege,

\begin{abstract}
In your new home here you'll discover the true meaning of contentment. You'll awaken everyday to the ever changing life of the harbour and colourful inner city cameos. Arts, culture, entertainment, sports, fine restaurants and exciting shopping...they're all within a leisurely stroll along your waterfront promenade. ${ }^{28}$
\end{abstract}

The description of the surrounding activities emphasised a cultural atmosphere directed at a mature resident, and at the transformation of the once industrial unpopulated place into a public, residential one. The conversion later proved an aid in the Wellington Waterfront Framework's agenda, as other warehouses along the waterfront were also later converted (refer to Chapter 02, Odlins conversion), as well as leading to the introduction of public places and cafes to accommodate the new influx of people and activities.

\section{Aim of the Interior Intervention}

Several design elements were employed to retain the character of the buildings when designing the apartments:

- Large $5 \mathrm{~m}$ wide corridors were to run the length of the building, maintaining the height throughout the upper 2 floors by providing vertical openings in the level 2 corridor and maintaining the vertical height in the accumulator tower;

- $\quad$ The revealed brick walls, steel beams and columns, hoist and bale hatches were to be retained;

- The interior intervention was to be driven by the industrial character of the building. All attempts were to be made to expose the steelwork, and new materials were chosen to reflect the original ones. These included steel mesh and other industrial quality materials along the colonnade and plaster walls in the apartments. Steel banisters and balustrades were to be employed in the stairwells.

\section{$\underline{\text { Interior Intervention }}$}

The strengthening methods employed in Shed 21 differed to later examples discussed in this thesis. A small amount of new exposed steel had to be inserted as the loads were $28 \quad$ Historic Places Trust Archives, Waterloo on Quay Pamphlet. Visit 18 May 2011 shared by the new shear and structural intertenancy block walls, as well as the new columns. These ran up the existing brick walls to strengthen the brick external walls. The existing steel columns and beams were left exposed, and the new walls stopped at the steel beam junctions allowing for their exposure. Another element of the architects' preservation approach and utmost respect for existing features was the treatment of existing materials. In order to fire proof the existing steel, the colours were picked to be those most resembling existing steel, giving these elements a flatcote, grey hue. The new additions also worked well with the existing materials, so as not to dominate the old materials. Colours were left, plain and neutral. The intertenancy walls had a plaster finish painted with Resene Parchment. The common area spaces, such as the corridors were carpeted in a grey hue, matching the steel, although the decision to carpet the floor was one that covered up the existing concrete floor below, hiding the existing construction. This removed the raw loft look, prevalent in the pioneering warehouses of New York (see previous chapter).

\section{Kitchen and Bathroom}

Shed 21's kitchens were conventional designs in all 43 apartments. Although the kitchen looked out onto the dining/ living room, it was situated against two walls, and was fixed. The specification was very detailed, specifying fine points such as the type of cutlery system, and the brand of fridge and waste disposal unit. The kitchen joinery and cupboards were made of paint finished MDF, with a stainless steel basin and bench. The cupboards were generally a melteca plastic material on the inside with a melamine kickspace, a popular kitchen specification. The generic design of the kitchens is somewhat surprising. New plastic finishes such as PVC flooring, wall-linings, Formica bench-tops and melamine panel cabinets used throughout the interior of Shed $21 \mathrm{~s}$ were introduced in the kitchen design guides of 1974 and 1981. Once expensive, today these materials are the cheaper option and are, therefore, ubiquitous. ${ }^{29}$

The bathroom consisted of Villa board, paint finish GIB lining, white tiles (in some apartments), formica benches, melteca cabinets, toughened glass mirror doors and a bidet. Again, everything was specified right down to the toilet roller holder, with little freedom of choice left to the resident.

\section{$\underline{\text { Acoustic protection }}$}

The intertenancy walls used a $300 \mathrm{~mm}$ thick Polyblock Insulform wall on a $500 \mathrm{~mm}$ thick beam to apartment walls facing the corridor hallway $(250 \mathrm{~mm}$ at level $3 \mathrm{a}$ ) and $240 \mathrm{~mm}$ (200mm level 3a) and block work to intertenancy walls. The Polyblock was an innovative material to use as it had

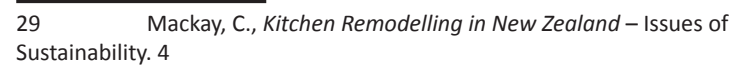



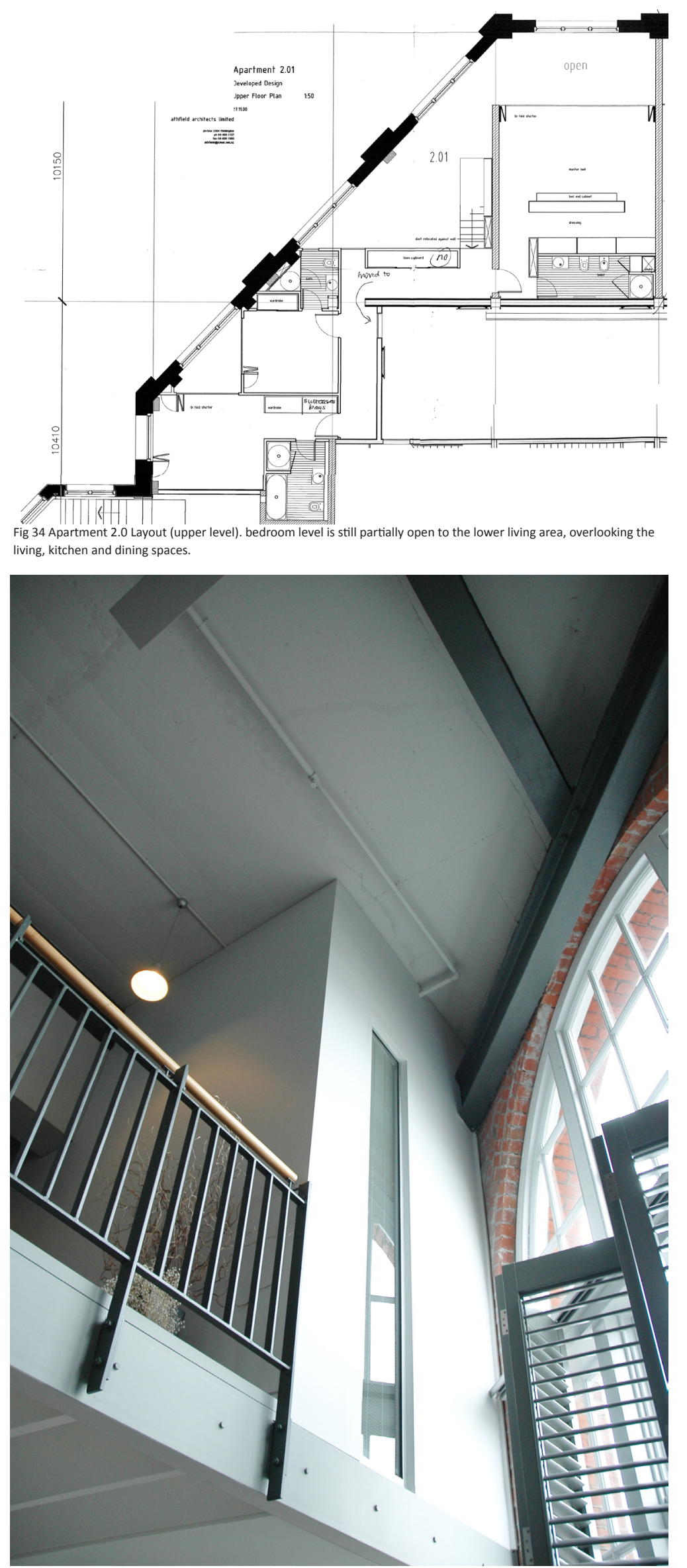

Fig 35. Mezzanine level overlooking lower level. Large full height windows allow for maximum light. Curtains were replaced by custom designed bifolding shutters. 

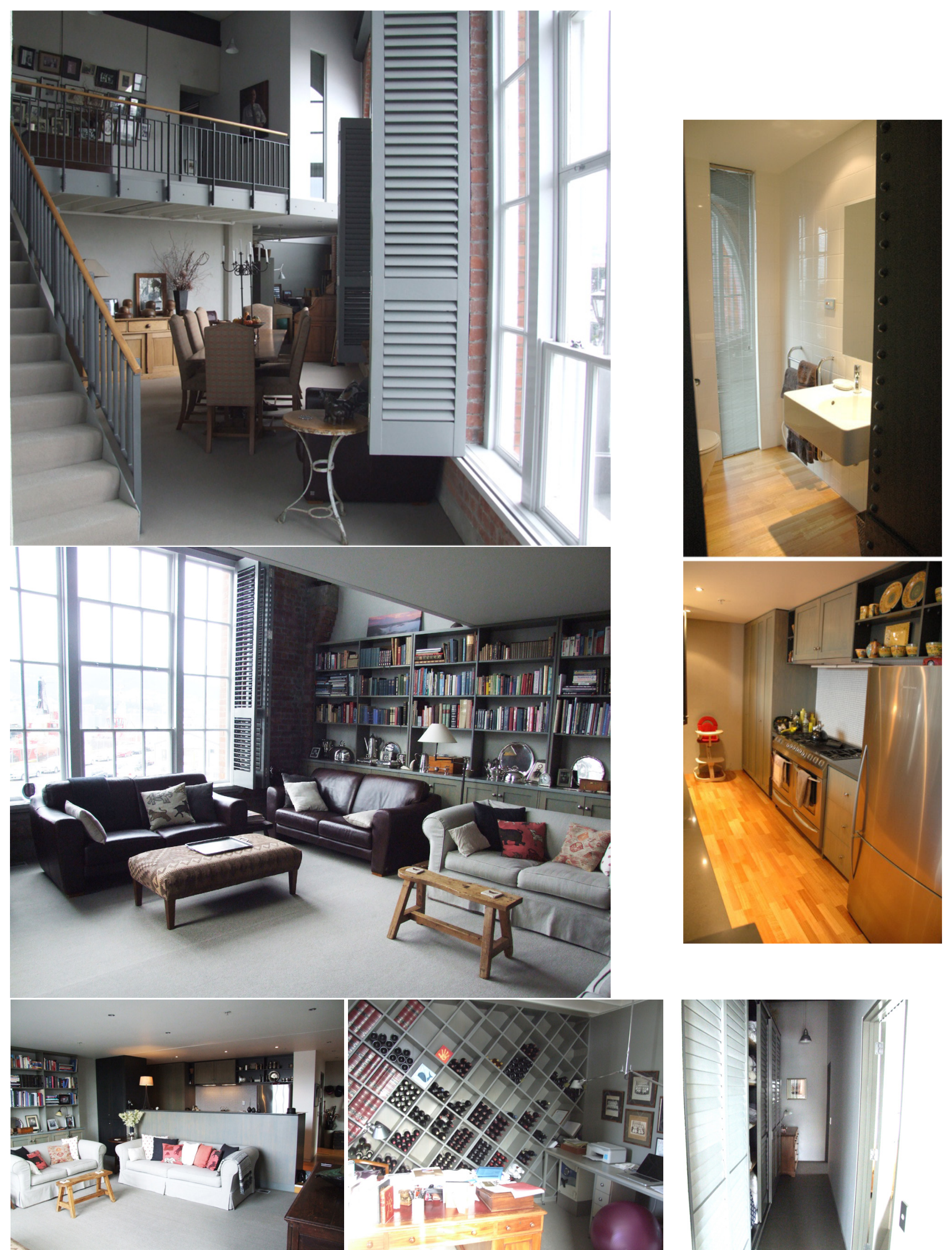

Fig 36. Interior of Apartment 2.0. This was the largest apartment in the building and had the most unique configuration being situated on the corner. Apartment 3.1 was one level above, however it was much smaller. Double 列 having a sense of "home". This is visible through the carpeted areas throughout the apartment, popular kitchen and bathroom materials. The owners of this apartment had flexibility in the final design of their apartment, including demolishing part of the wall on the ground level to make a larger space that it was initially designed as. 


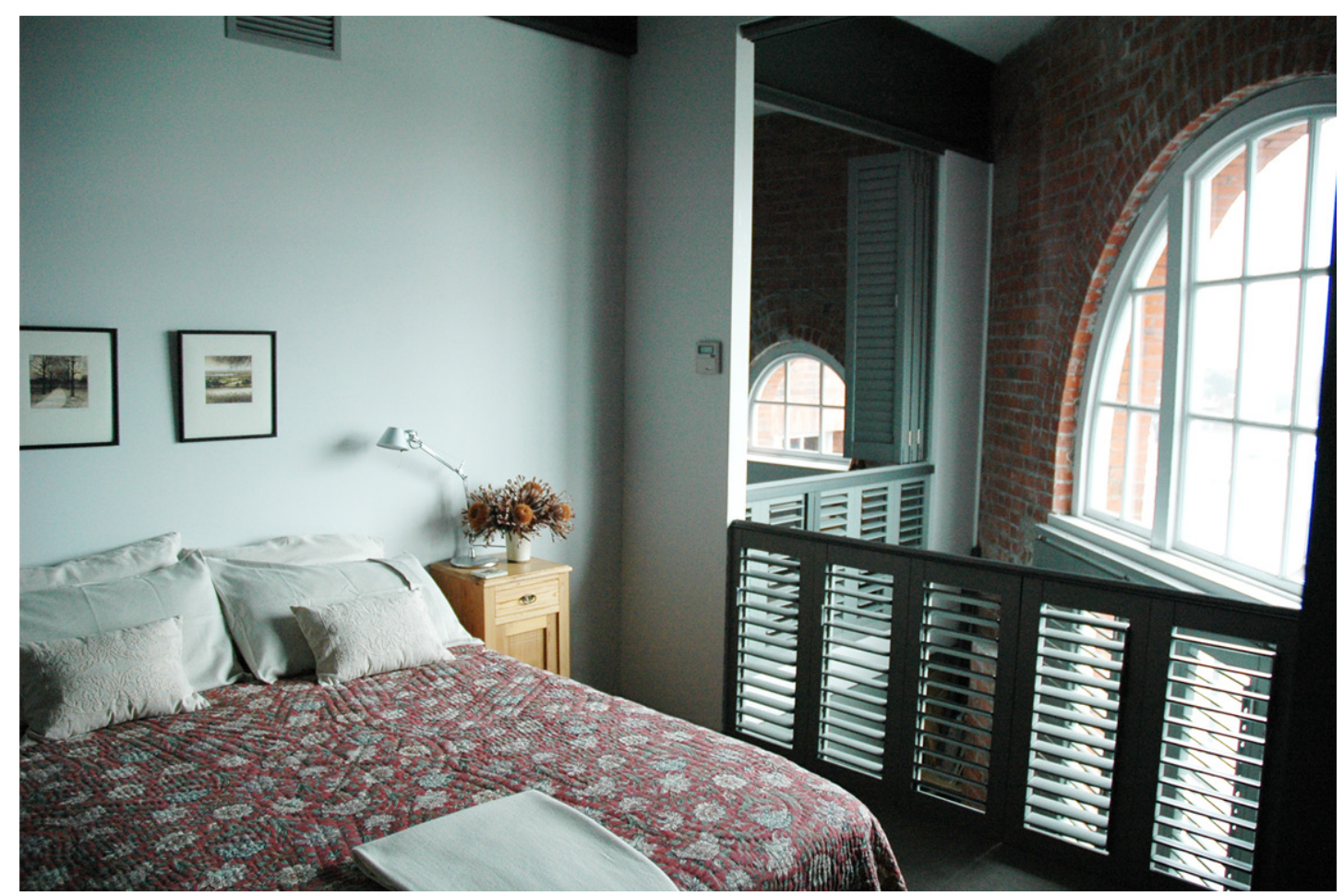

Fig 37. Bi-folding timber shutters were used to close off the space for privacy and against light

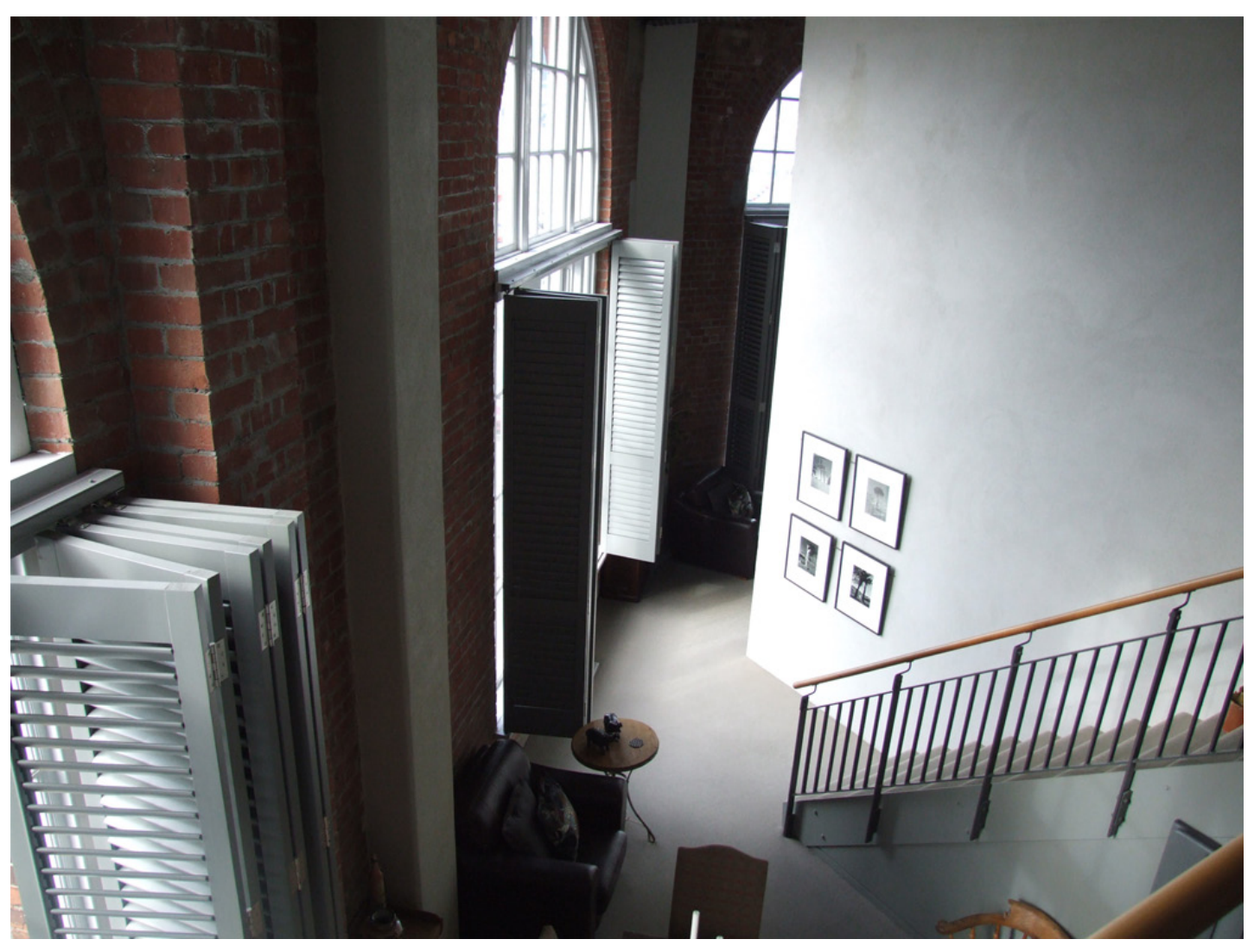


higher strength, insulation and acoustic properties than concrete block. The apartments facing the street side had a block wall of $200 \mathrm{~mm}$ thickness as opposed to the harbour facing intertenancy walls which were $250 \mathrm{~mm}$ thick. The wall facing the corridor was also much thinner for the south side apartments, with a $150 \mathrm{~mm}$ timber framed wall with $9 \mathrm{~mm}$ ply bracing glued and screwed to the outside. The mezzanine level flooring was timber with $20 \mathrm{~mm}$ particle board glued and screwed on top.

\section{Structural Upgrade}

The volume of the ground floor space was reduced due to strengthening requirements. Attempts to mitigate the loss were made where possible. The building was to be strengthened to well in excess of the Wellington City Council's earthquake code requirements. Steve Rowe of Newcrest Development sated that, "the building was basically so strong, strengthening beyond the code requirements would be straightforward." ${ }^{30}$ The building was strengthened to 70 percent of the current building code at the time for ten years upon initial conversion. ${ }^{31}$

Athfield Architects stated that one of the things that saved the building was the insertion of the multitude of intertenancy shear walls between each apartment. This separation into smaller spaces was ideal for apartment spaces, but would not have been ideal in an office environment. ${ }^{32}$

The scope of the structural work included demolition of the existing secondary roof trusses, gantry cranes and crane rails, and significant welding of reinforcing to existing steel members. Weldplates, bolts and cleats were used alongside the concrete block walls and insitu concrete. Because the new additional strengthening work acted as a design intervention and was therefore left exposed, the welding in the finished building and in particular the butt welds of stock lengths were to be neatly finished. Various steel beams were to be fitted with shear studs to enable them to act as a composite with the concrete floors. Steelwork, which was cast in concrete, was to be left unpainted but cleaned. ${ }^{33}$

The new stairs had vertical I beams inserted, that ran up the brick walls but took the pressure away from the brick. Where cuts were made in the brick, new fabricated steel plate stiffening mullions were added. The mullions were inserted alongside the existing internal brick walls. At the ground level, a deep concrete beam was also added to

\footnotetext{
30 Moran, P., Shed 21 on track to become apartments, , Dominion, 16 Nov 2000

31 Wale, A., Apartment 2.0, Waterloo on Quay Apartments, message to author. 23.11.11. email

$32 \quad$ Athfield. Z., and J. Hardwick-Smith. Personal Interview. 11 November 2011

33 Dunning Thornton Consultants Ltd, Specifications. Waterloo on Quay Seismic Strengthening and Redevelopment of Shed 21 for Shed 21 Ltd Stage Two Contract., August 2001. CD
}

support lateral forces from the south.

New columns were added at ground level. At level 1 new block and concrete shear walls at various thicknesses ranging from $200-400 \mathrm{~mm}$ were inserted, similar to the Hannah Factory (Case 3). These were much thicker at the lower levels where they ran in the east west direction. New concrete shear walls also ran in the north south direction, in line with the new apartments.

The masonry was strengthened by inserting new $250 \mathrm{~mm} x$ $500 \mathrm{~mm}$ concrete column mullions around the internal brick wall perimeter, which spanned the full height of the building.

\section{$\underline{\text { Fire Protection }}$}

Items of steel structure which required a paint type fire resistant rating were to be treated with a suitable solvent and have all weld splatter removed, as well as having the sharp edges ground down. They were then painted with proprietary intumescent paint to give a specified fire resistance rating. Two top spray coats of Super Gloss Enamel, 36 microns thick, was to be applied and the colour approved by the architect.

\section{$\underline{\text { Wall finishes }}$}

The apartment wall finishes in Shed 21 were a cement plaster sponge finish applied to exposed surfaces. Plaster was only applied to the exposed side of the walls. An acoustic sealant with a STC (Sound Transmission Class) rating of 55 mins was used in the apartments intertencancy walls.

Typically the fire rated walls in the apartments were $2 x$ $13 \mathrm{~mm}$ fyreline walls on the inside face of the apartment and $1 \times 13 \mathrm{~mm}$ fyreline sheet attached to ply bracing on the external side facing the corridor. Sound control infill and fire sealant was applied to all floors, wall and ceiling junctions.

Flame proof paper was inserted into the fire rated walls with fibre cement linings. Insulation was provided to fire and acoustic walls and a damproof membrane was inserted between all timber framing and concrete surfaces.

\section{Brickwork}

The brickwork was to be washed and repointed. Painting of the surfaces was to be limited so as not to damage the bricks' surface. All the window joinery was to be retained and repaired by splicing in timber in localised areas of damage or decay. ${ }^{34}$ The apartment design was minimalist to provide a contrast with the existing facades and structural elements which were left exposed, such as the brick internal walls,

\begin{tabular}{l}
\hline $34 \quad$ Dave Pearson Architects Ltd, Shed 21 Assessment of Effects, prepared for \\
Newcrest Holdings Ltd.
\end{tabular}


Structural Upgrade Analysis+ Diagram
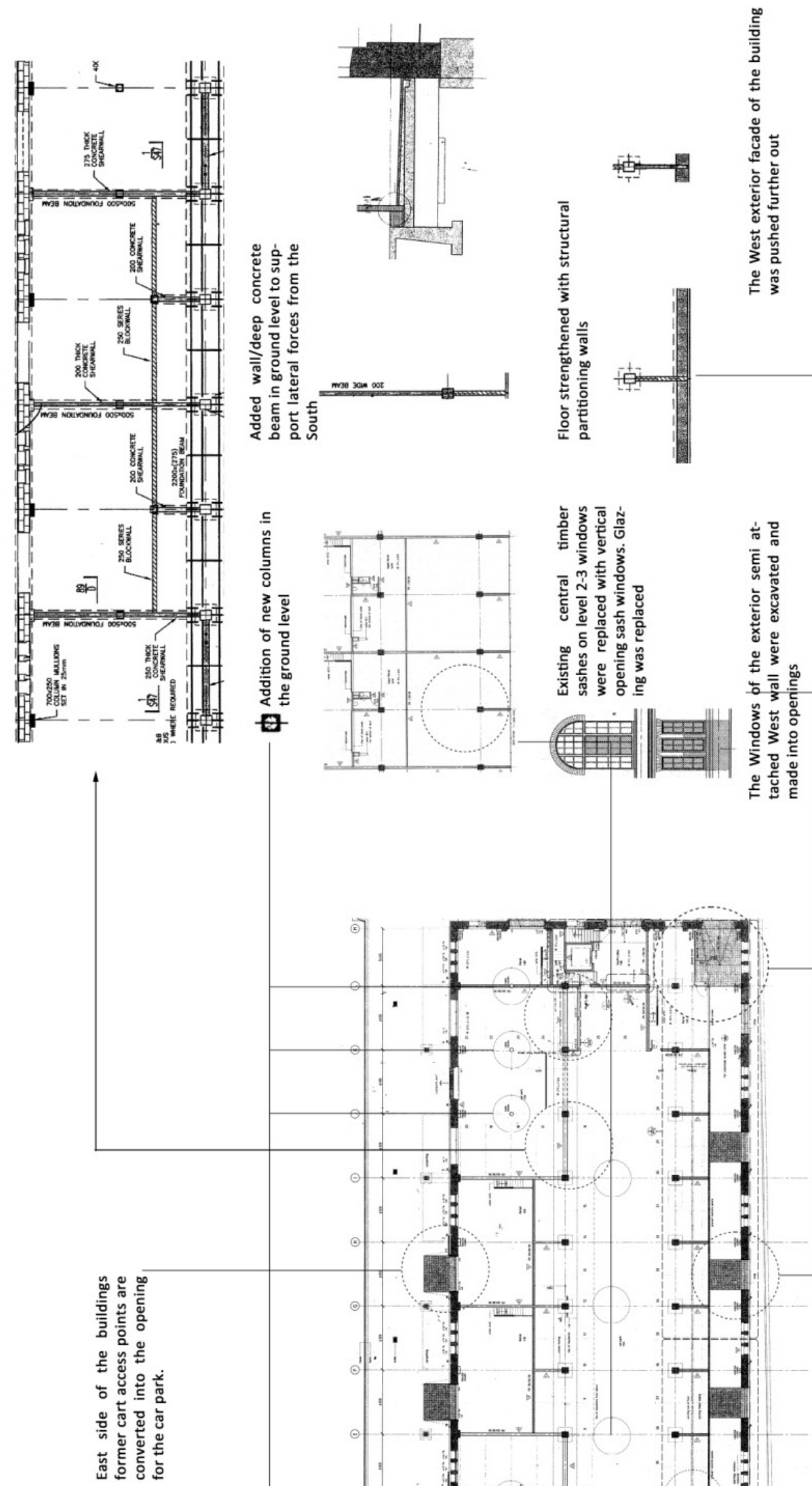

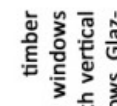
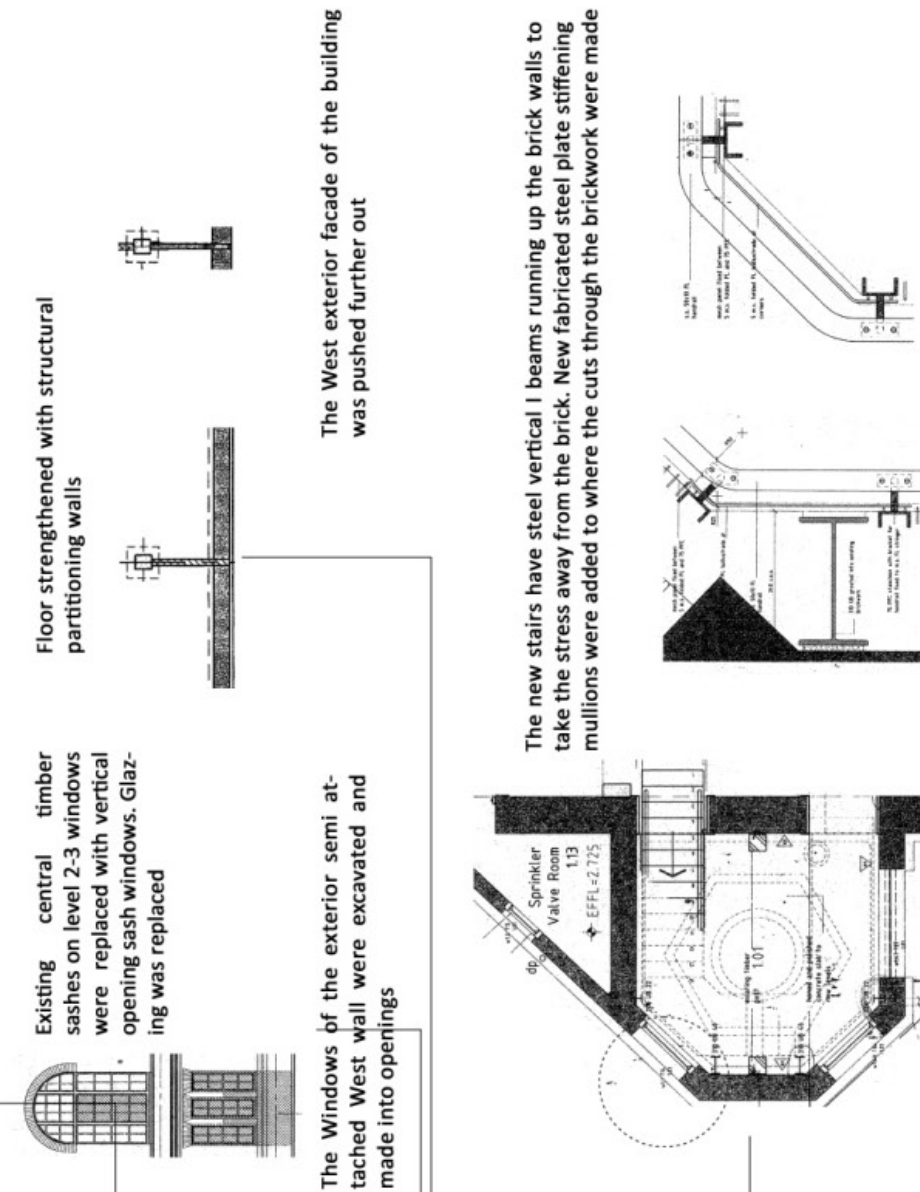

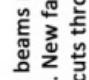

究总总

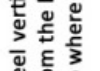

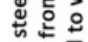

空京要

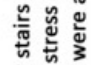

突芒参

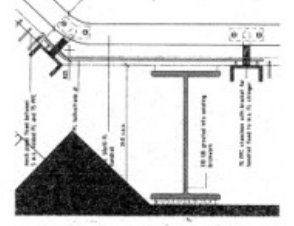

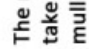

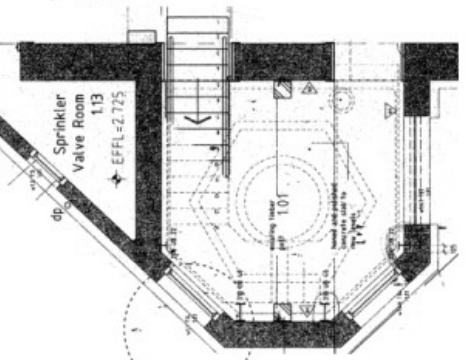

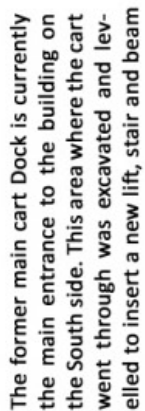

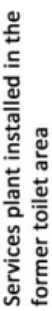

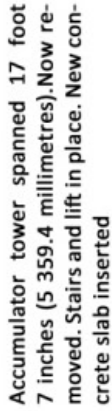




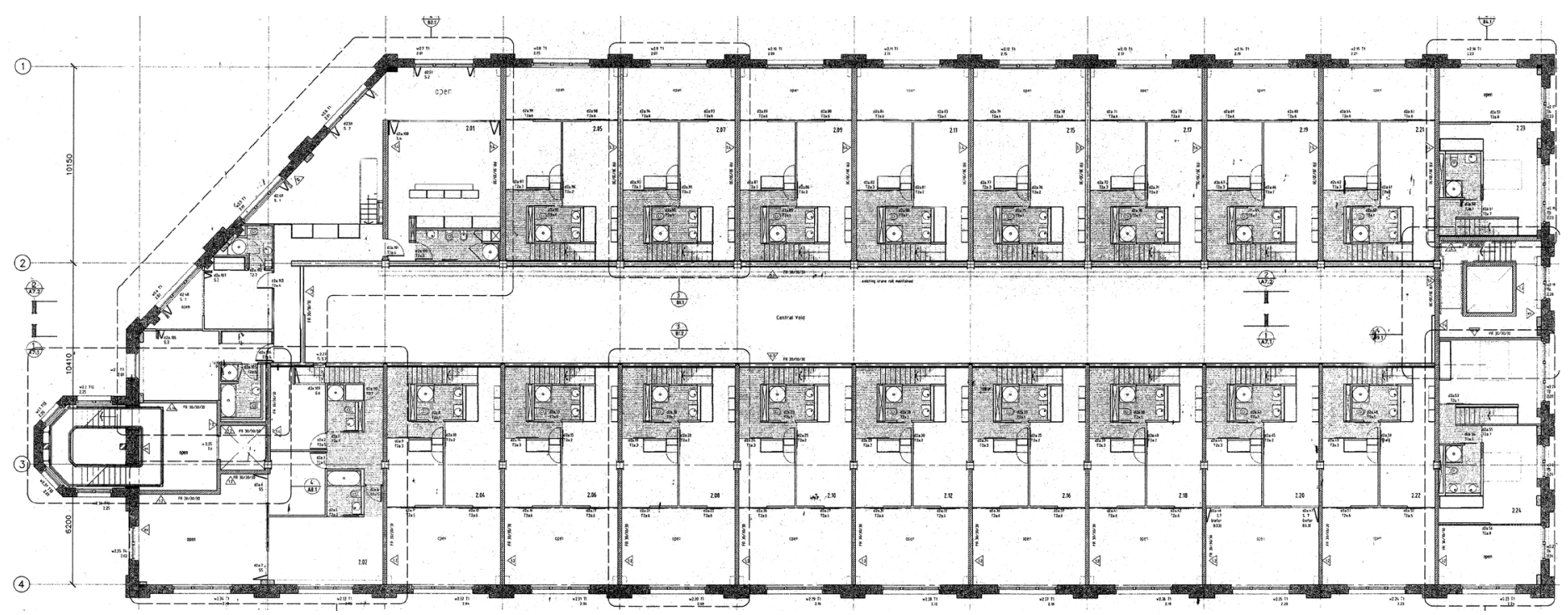

Fig 39. Linear apartment layout reflecting existing structural grid. Apartment 2.1 is located in the upper left corner.

the ceiling pipes, the steel joinery and beams and trusses. This highlighted the building's original character as a wharf warehouse.

The largest impact of redeveloping a warehouse into residential apartments was the gutting and removal of the existing features needed to deal with wool. Also, the entry points that were specifically built to design for easy access and shipment of the cargo were altered to fit the new purposes; entry points for the residents and their cars, earthquake restrengthening and insertion of fire safety egresses, plumbing and access ways.

\section{Demographic/Residents}

The demographic of the residents inhabiting the Waterloo Quay apartments is middle aged clients.

As stated in a newspaper paper article at the time of the apartments being sold off the owners of the apartments were described as, "ageing but ageless...fit and rich, with enough time on their hands for fun and games-and divorcebut too busy to mow the lawns." 35 The article also stated the demand for such units could be attributed to: "our ageing population, increase in the divorce rate, and the consequent changing size of the family unit. The advent of the 1990s lifestyle." Other factors that were seen as appealing features of the apartments were the close proximities to shopping, dining out and drinking. The increase in demand for low maintenance included having convenient housing, preferably looked after by someone else. Security was another noted factor; the ability to be safe in the inner-city, and the drive-in access under the same roof were sought after.

An apartment survey directed by real estate property agents showed that Wellington apartments were being taken up by people in their 40 s or older, and particularly by single women living on their own. Raine and Hornes valuation director Susan Mackay stated that, "many of these people in their early 40s, have been identified in the US as being, "of an age that doesn't want to grow old." ${ }^{\prime 36}$ These older residents were described as those who would previously go to Waikanae on the Kapiti Coast to retire, and were instead interested in retaining something in town as well as owning something up the coast. The small size of these apartments were stated as being perfect for small families, affected by divorce, who no longer have the time to look after their property. Living in inner-city apartments was the perfect solution to this as they were easy to look after, or looked after "by a paid central management." 37

\section{$\underline{\text { Real Estate Issues }}$}

The apartments were sold a month prior to completion with prices ranging from $\$ 320,000$ to more than $\$ 1.3$ million. Prices averaged $\$ 450,000$ on the harbour side and $\$ 350,000$ for those on the city side, ranging in size from $91 \mathrm{sq} \mathrm{m}$ to 190 sq $\mathrm{m}$.

\subsection{Waterloo on Quay Apartment}

The residents at 2.01, are david and Annette Wale an elderl semi retired couple, have occupied the apartment since it was first put on lease in 2000. Some alterations were made to their apartment by other architects. After the purchase, \begin{tabular}{ll}
\hline 36 & ibid \\
37 & ibid
\end{tabular} 

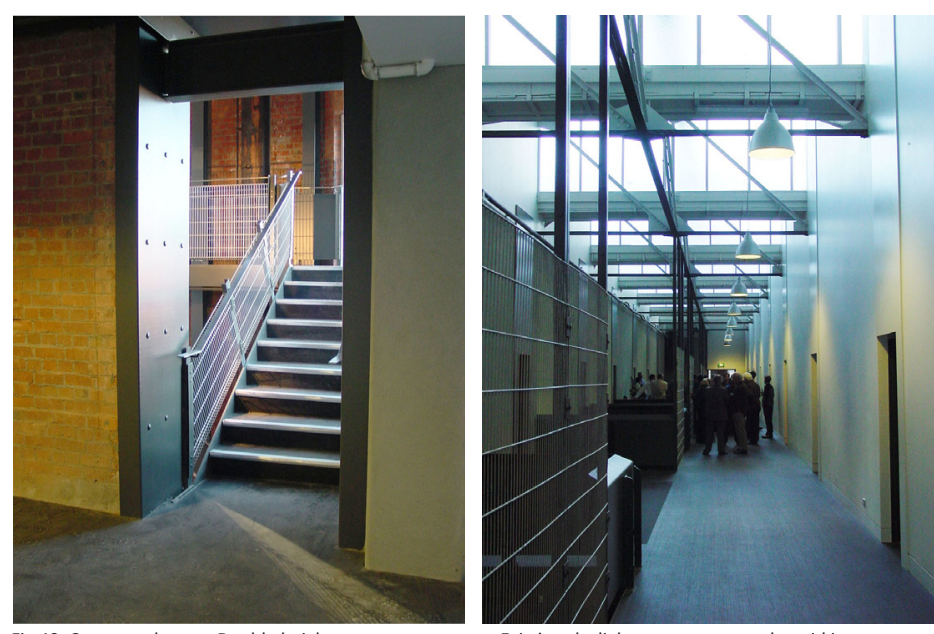

Fig 40. Communal areas. Double height spaces are present. Existing sky lights were preserved to aid in light filtration. Use of steel visible in the details.

the owners modified the space by combining two former apartments into one. This allowed for open space on the ground and separate bedrooms on the second level. The insertion of bi-folding blinds in the bedroom area on the mezzanine added privacy without blocking out the light. These leave the space open, without resorting to inserting walls. Unique storage systems were used in the form of free standing full height shelves, which were all moveable.

The most obvious features in the apartment are the double height spaces, abundance of light from the ecclesiasticalstyle windows, the exposed and unpainted brick and the open plan. The additional features and strengthening worked alongside the existing fabric of the building are also evident. The steel bracing is left exposed within the apartment. Furniture within the bedroom, in the form of floor to ceiling height shelving, acts as a spatial boundary. The original concrete floor is covered by a carpet, however, hiding the original floor. Again this was done not because of sound transmission (the floor is concrete over $250 \mathrm{~mm}$ deep), but because of the general public preference to have carpet under foot. Exposed concrete floors in New Zealand houses are not a common feature. ${ }^{38}$ The mezzanine floors are structural diaphragms. Of note are the diaphragms which include particle board flooring and plywood ceilings.

The apartment has a very polished, homely and comfortable feel. There is minimal external noise, and the spaces are very spacious especially in the lower levels. The fully carpeted areas and the conventional kitchen give the apartment a domestic, feel, not dissimilar from a conventional home. The dimensions and existing fabric, however, were really determined by the original programme of the former warehouse. The exposed structure is well juxtaposed against the interior decoration and personalised effects.

38 Gray, John. Personal Interview., 2.September.2011

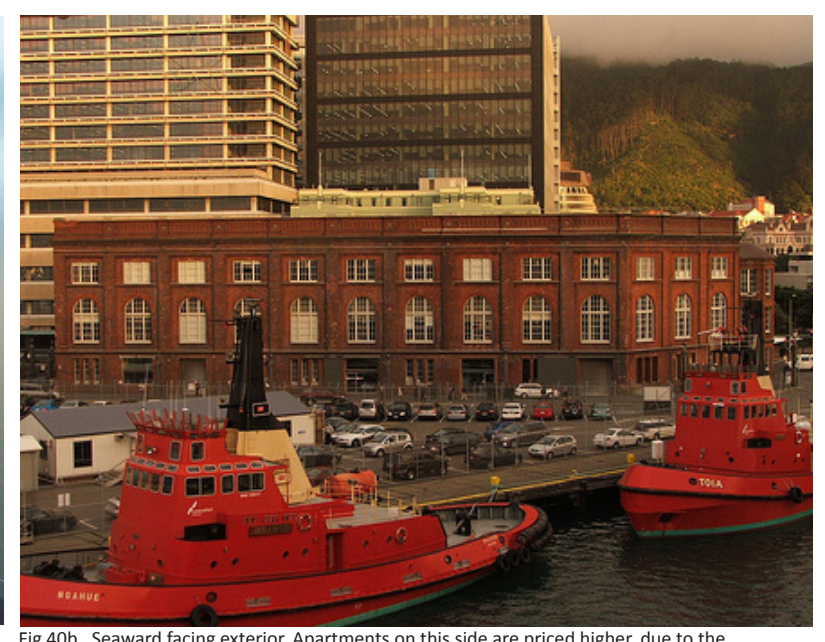

Fig 40b. Seaward facing exterior. Apartments on this side are priced higher, due to the maximum light and sea facing views.

\section{Conclusion}

The reuse and adaptation of Shed 21 was handled with utmost respect and careful consideration by the architects, developers, Historic Places Trust, and the Wellington City Council, to preserve this historically significant building's original character and use its existing elements to highlight its previous use. Architectural features of historic significance were identified prior to the conversion. The aim was to alter as little as possible of the most valuable elements. The building's existing structure was rejuvenated and cleaned, allowing the original character of the building to remain. Similar design features can be compared to those of the warehouse lofts of New York, especially in the retention of existing structural elements like the steel beams and columns, high floor to ceiling dimensions, large windows and historic features important to the building's heritage, such as the sidings, accumulator tower and brick. The big windows and skylights in the ceilings on the upper levels provide the effect of a New York conversion in the Waterloo Quay Apartments. The creation of 43 apartments within the core resulted in uniquely designed spaces for the inhabitants, whose dwellings differ from those of commercial modern apartments. Although the building's immediacy on the water's edge has diminished since its construction 100 years ago, its presence was revived and uplifted after the renovations, by maintaining its connection to the port and harbour through the reinstatement of people and their activities within its proximity.

Shed 21 had an esteemed historic classification, a dominant waterfront presence and was part of the Wellington wharf's shipping history. It also had significant architectural features of note. Economic and political pressure from the developers and city council meant the conversion of this warehouse was conventional and less experimental in many ways, having 
to comply with the potential demands of residents' backgrounds and their needs for comfort. Comparing the conversion of Shed 21 with early SoHo lofts shows minimal similarity, although one of the most visible outcomes in the modification, was that the building retained its former quality as a warehouse, and its original programme is still visible and inherent. As Athfield Architects stated,

"Shed 21 still feels luxurious because of its opulent scale shift. An average apartment within the building retains windows of a scale three times larger than normal." The original fabric was retained as much as possible, although the idea of home-comfort was also introduced.

A sense of history was instilled in the large mass of

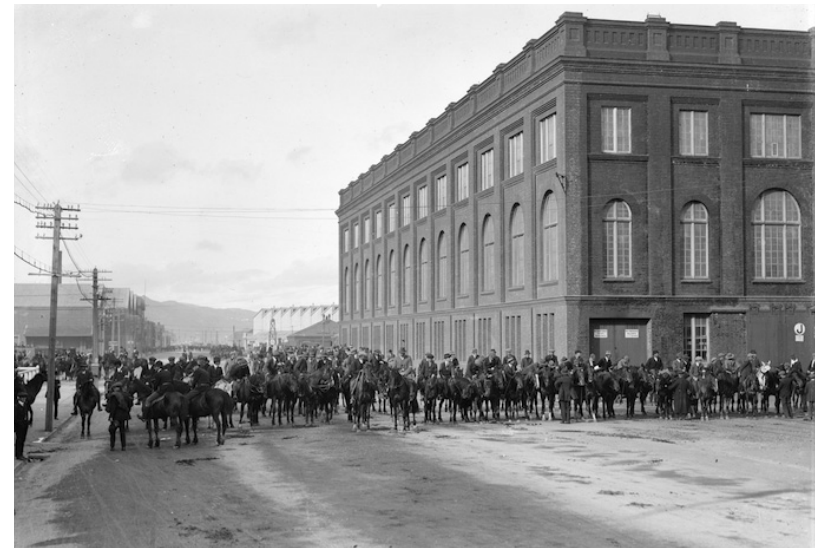

Fig 41. Shed 21 during the 1913 waterfront strike. West face is still closed off.

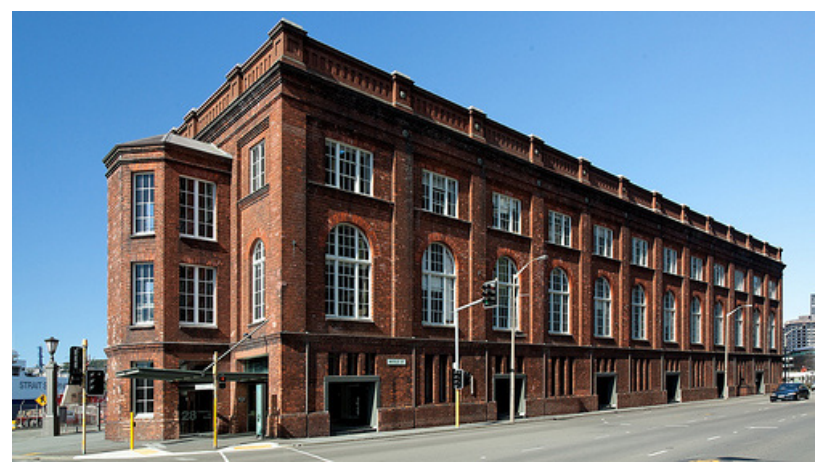

Fig 42. Converter

the building which was translated successfully during the conversion into residential apartments. Although changes were made to accommodate specific needs of the clients and the vision of the property developer, the former warehouse did not lose some of its integral features. Upon conversion the building still kept the sense of its original character and traces of what it once was used for. The success of its conversion can be attributed to the good work that was done on the buildings existing heritage, this sound analysis and theoretical approach achieved the final outcome. 
02: Co. Building

\section{Cable Street, Wellington}

It is a rare occurrence for a great building to be completed by the same person who began it. - Leon Battista Alberti
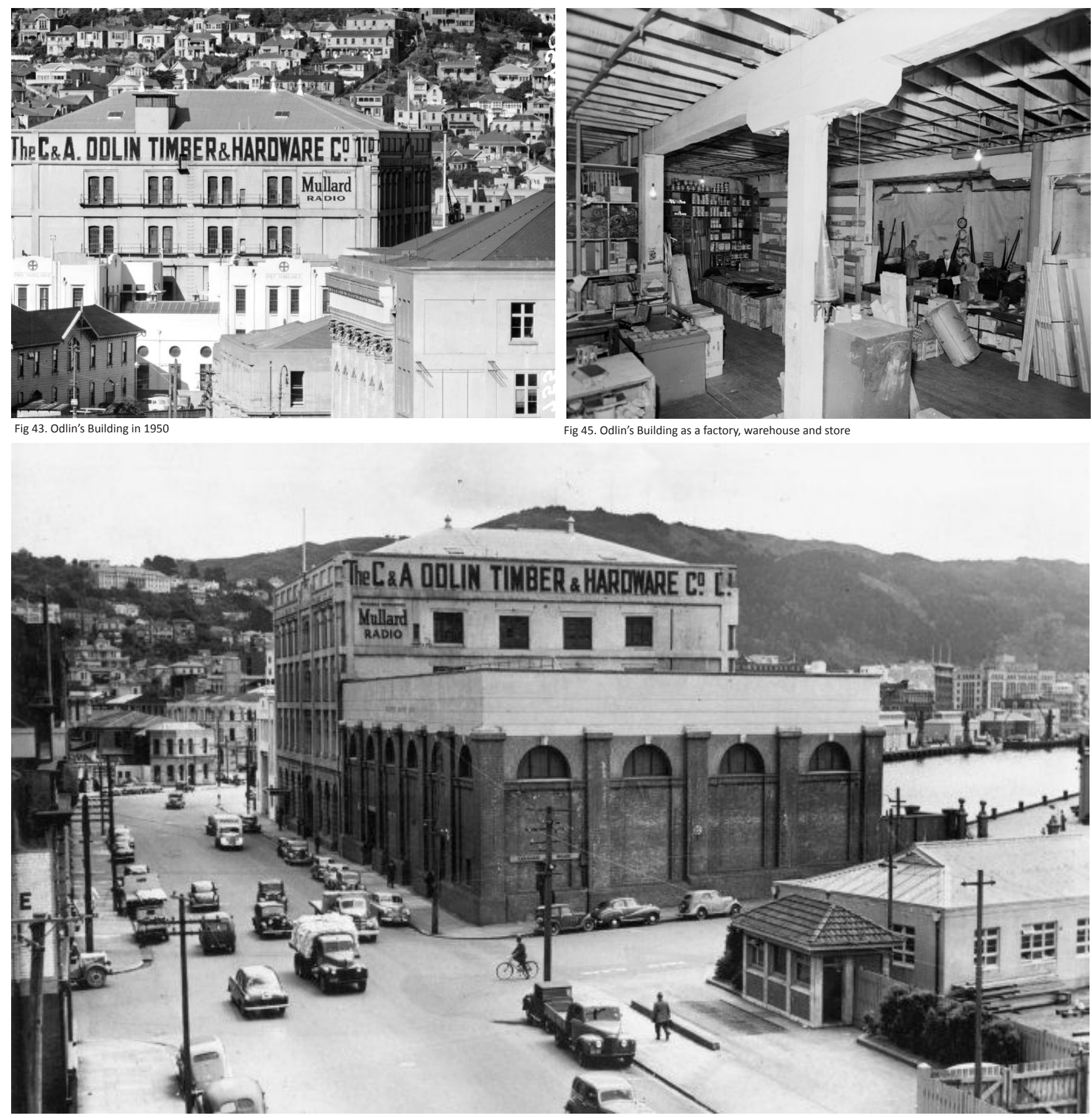

Fig 44. Odlin's building from Cable Street in 1953. Shed 22, a warehouse also later converted is the brick building adjacent to it. 


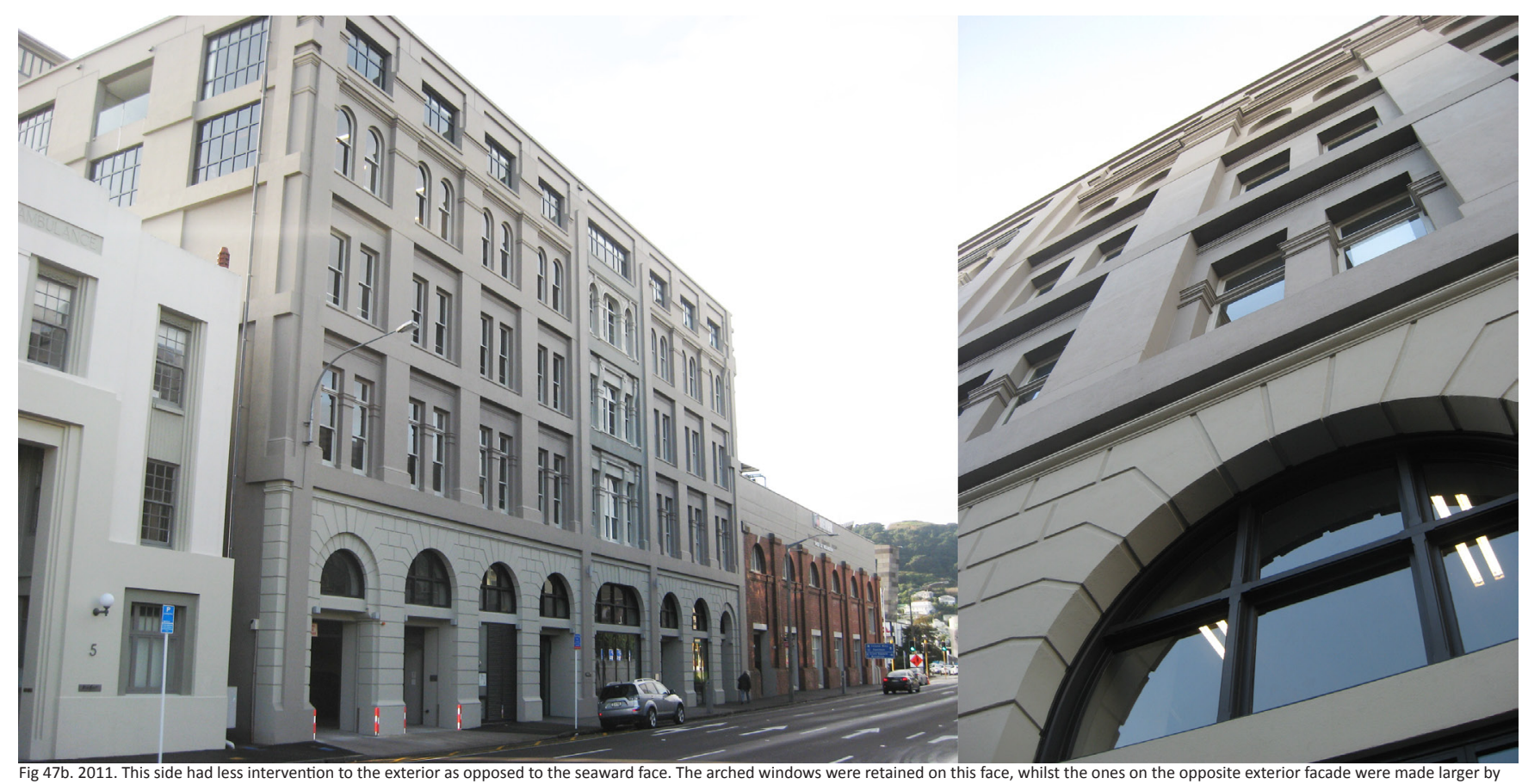
combining two to form one.

were still occupied by Nielsens Ltd.

This continued for many ears and it is uncertain when this latter use ended. ${ }^{9}$

There were many changes in the building's functions over the years however, the biggest change was the removal of the head offices. A lot of space was freed up when the head office relocated to the Willbank House in the 1970s, and then later to Petone. ${ }^{10}$

The ground floor shop and first floor showroom were regularly altered and modernised to cater for changes of use and to improve their appearance for customers, suppliers and staff. These included installing a lift well in 1940, £3600 allocated to "reinstate" the building which was largely spent on plumbing and drainage in 1945, and raising the roof and installing a new lift machine costing $£ 2000$ in 1954 . Several alterations to shop and mezzanine level were done in 1957, including a new cart dock opening, and a new toilet block which was installed in $1964 .{ }^{11}$ Other modifications included regular modernisation and alterations to the ground floor shop and first floor. Much of the interior had been altered by stripping of the original internal joinery, linings and fittings.

Thus the building was modified and maintained over the years whilst still serving as a warehouse. The building was built soon after the company's formation and served as the $9 \quad$ ibid $10 \quad$ ibid

11 Odlin Timber and Hardware Co. 11-21 Cable Street, shop and store. 8 Aug 1964. Plan and Specification. company's headquarters for all but the last decade or so of its history. ${ }^{12}$ The architect however is unknown. As discussed earlier, it was not uncommon to have an unknown architect as the designer of an industrial building. ${ }^{13}$

\section{$\underline{\text { Historic Significance }}$}

In 1998 the building received a Category 1 Historic Classification from the New Zealand Historic Places Trust (NZHPT). ${ }^{14}$ The listing was based on criteria under the category of Aesthetic Architectural History and reflecting important or representative aspects of New Zealand history

as well as the fact there was association with persons or ideas of importance in New Zealand history. ${ }^{15}$ The building's location was also a factor in determining its classification, as it was located within the Jervois Quay/Cable St Lambton Harbour Historic Area, which has been recognised as a precinct of architectural value since 1972 by the NZHPT. ${ }^{16}$ As with Shed 21 and other warehouses on the waterfront, Odlin's location meant it was also part of the Wellington Waterfront Redevelopment, guided by the Wellington Framework. ${ }^{17}$

\footnotetext{
12 Historic Place Assessment Under Section 23 Criteria., NZHPT, Wellington, NZ., 2002

13 Berens, C. Redeveloping Industrial Sites: A Guide for Architects, Planners, and Developers, 33

14 McLean, G., Odlins Building 11 Cable Street, Wellington, New Zealand Historic Places Trust. Web. 6 Aug 2011.

15 Historic Place Assessment Under Section 23 Criteria No. 408., New Zealand Historic Places Trust, Wellington, NZ, 2002

16 McClean, R., Internal Memo, NZHPT, 12 August 2002

17 Wellington (N.Z.). Waterfront Leadership Group, Wellington (N.Z.) Waterfront Leadership Group,2001.
} 


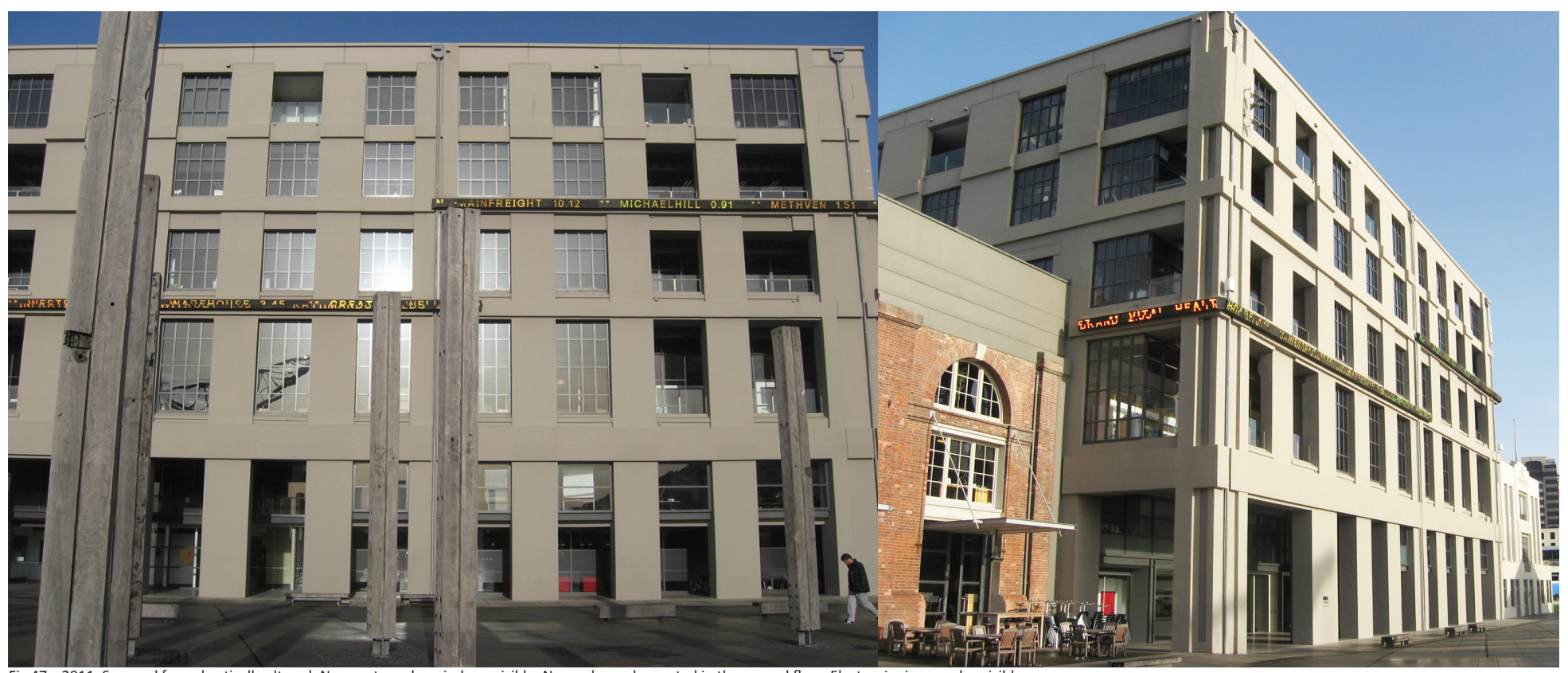

The NZHPT described the Odlin's building as a rare example of a preserved Edwardian warehouse and factory building. The conservation report also described the Odlin's building as an important example of Wellington's industrial port warehousing, facilitating the growth of trade.

\section{A definite sense of the turn of the century commercial warehouse environment on the Wellington waterfront has been preserved by the continued existence of the Odlin's Building. ${ }^{18}$}

Both Shed 21 and Odlin's warehouses were built on reclaimed land close to two of Wellingtons' oldest streets, Thorndon Quay and Lambton Quay Wharf. Reclamation of land was a result of the limited amount of available land, and expansion took place from the 1850s onwards. Between 1893-1901

Waterloo Quay and Glasgow wharves received 3 acres $\left(12,000 \mathrm{~m}^{2}\right)$, in 1901-1914 Barnet, Cable and Chaffers Streets gained 18 acres $\left(73,000 \mathrm{~m}^{2}\right)$, and 1906 saw Waterloo Quay gain 34.5 acres $\left(140,000 \mathrm{~m}^{2}\right)$ of land. ${ }^{19}$ The location of these factory and warehouse buildings was essential for trade and shipment purposes, but the introduction and development of new ways to store goods eventually resulted in their relocation and demise.

The siting of this building near Taranaki Wharf is now a rare physical reminder of how private companies last century and early this century leased Wellington Harbour Board land and $18 \quad$ Historic Place Assessment Under Section 23 Criteria, NZHPT, Wellington, NZ. 2002

19 Ward, L. E., Early Wellington-Reclamations. Whitcombe and Tombs Limited, 1928, Auckland. Web. 12.07.2011 built substantial businesses close to one of their main forms of carriage-sea transport. Odlin's once leased large parts of the wharf environs and after their Taranaki Wharf yard closed also opened a retail outlet a short distance away on the corner of Cable and Tory Streets. ${ }^{20}$

\section{Architectural Significance}

The Odlin's Building was constructed as an industrial building in an Edwardian style. ${ }^{21}$ Its facade eschewed the Edwardian excess that typified buildings of that period, such as the Public Trusts Building (1908) at the corner of Lambton Quay and Stout Street, but reflects the plainer design characteristics of the industrial buildings of the time.

Edwardian Style indicators were:

- Rectangularity of facade emphasised by treatment of parapet or cornice

- Strongly emphasised piers

- Strongly emphasised arch window heads and entrances

- $\quad$ Plain or plastered face brickwork

- Flat spandrels recessed behind plane of piers

- Strongly emphasised base in rusticated form

- Restrained classical detailing on piers and archways

- Masonry construction.

A variety of materials were used in the construction of the Odlin's building, including Australian Hardwood and Oregon Pine timber floor and timber and steel mullions, Ironbark 20 Historic Place Assessment Under Section 23 Criteria., NZHPT, Wellington, NZ, 2000

$21 \quad$ ibid 
piles and posts reinforced with railway iron, and plastered brick exterior walls. ${ }^{22}$ The fifth or attic floor had huge single trusses spanning half the width of the building.

\section{Conversion}

In 1975, the Wellington City Council bought the derelict building for $\$ 500,000^{23}$, at a time when it had been classified as an earthquake risk building and was subject to a demolition order. It continued to sit largely unoccupied for several years. ${ }^{24}$ At one point it was used as a discotheque, often vandalised before undergoing a major face lift and refurbishment by the developer company Willis Bond and Co Ltd. Lambton Harbour Management Limited (LHML) had previously applied to the Wellington City Council for a permit to demolish the building to make way for a hotel on the site. ${ }^{25}$ The LHML later applied for a demolition permit and consent to use the site for parking space. ${ }^{26}$ However, a community outcry about the proposed demolition prompted the company to reconsider. Nine tender bids were received for the demolition of the Odlin's Building with several bidding firms from outside of Wellington. ${ }^{27}$ No investor was found at that time and the building continued to stand. Later in August 2002, LHML appointed Willis Bond \& Co as the successful proposer for the restoration of the Odlins Building. ${ }^{28}$

Dunning Thornton Engineers and Athfield Architects' entry was selected from the competition put out by the Waterfront Company. Their proposal was to redevelop the site for an estimated 20 million for the shell and apartments (excluding the interior fit outs). ${ }^{29}$

Athfield Architects proposed a rejuvenation of the building that included reusing the first flour levels as offices for the New Zealand Stock Exchange (NZX), Trademe, and Loyalty New Zealand. Locating the NZX there was a valuable decision for Wellington as it retained the city's status as the centre for business and its reputation as New Zealand's capital of finance. ${ }^{30}$ This redevelopment followed the existing world wide trend for office and residential users to gravitate to waterfront locations, ${ }^{31}$ in turn regenerating the derelict ports by instilling life and activity into them. There was also room

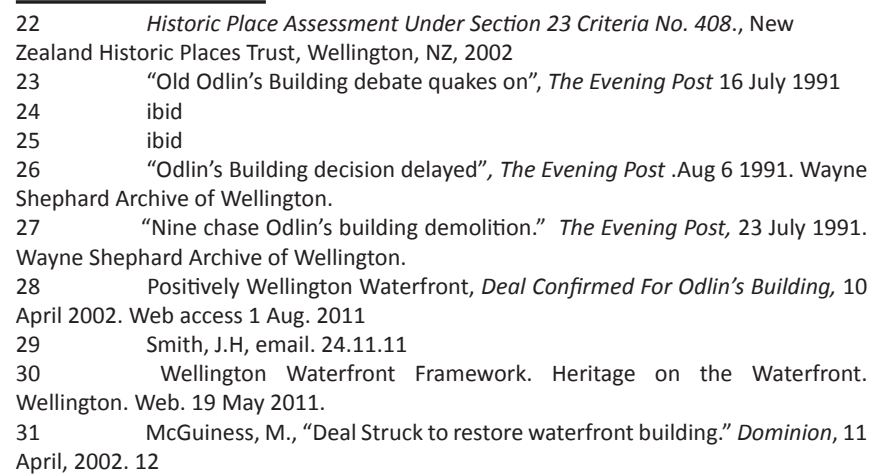

for retail spaces and the upper fifth level was designated for seven multimillion dollar apartments. Because the Odlin's Building was situated on the waterfront area, there was large public interest. This interest went beyond strictly heritage matters and related to the general use of public space. ${ }^{32}$ Initial submitted plans published in the Dominion Post were met by public outcry due to the large number of proposed changes to the building, which were seen as detrimental to its original context and history.

Wellington Civic Trust was concerned with the radical changes Athfield Architects initially proposed, and the lack of heritage consideration the building's makeover was receiving from the Waterfront Development Sub-Committee. Although the building was registered as Category 1, the New Zealand Historic Places Trust provided no direct protection for heritage and this was managed under the Resource Management Act and other different processes. ${ }^{33}$

The architects had contemplated other schemes, and had considered London's converted factory museum, the 'Tate Modern' as a precedent. However, the architects' intention to put a more modern glass box intervention on top of the building was rejected. ${ }^{34}$ In the end, the conservative political environment on the waterfront would not accept anything that affected keeping the shell unaltered from the outside. Because the historic building had to give a high economic yield, the changes had to be minimal and fit in with the Wellington Waterfront Framework scheme. ${ }^{35}$ Any interventions were closely monitored and the height and volume controlled. As a result, the Odlin's Building schemes were reworked several times.

Athfield Architects believed the redevelopment work reflected the surrounding context and how the building, together with the waterfront would develop in the next 1020 years. They predicted more public activity, circulation, and port activity, and thus modified the facade to allow public thoroughfare, and emphasised public activity on the ground floors. In order to make the building work, the architects pushed hard to demolish most of the seaward facade at ground level, leaving the colonnades.

\section{$\underline{\text { Modification }}$}

The Wellington Civic Trust group was initially unhappy with the large amount of modification on the seaward exterior facade. In 2003, a submission made to the Waterfront Development Sub-Committee entitled "Proposed Refurbishment of the

\footnotetext{
$32 \quad$ Historic Place Assessment Under Section 23 Criteria No. 408., New Zealand Historic Places Trust, Wellington, NZ,2002

33 Wagstaff, B., Heritage Advisor-Registration, New Zealand Historic Places Trust "Hannahs Factory question". Message to the author. 17.11.11. email

$34 \quad$ Athfield. Z., and J. Hardwick-Smith. Personal Interview., 11 November 2011

$35 \quad$ ibid
} 


\section{Modified North Elevation}

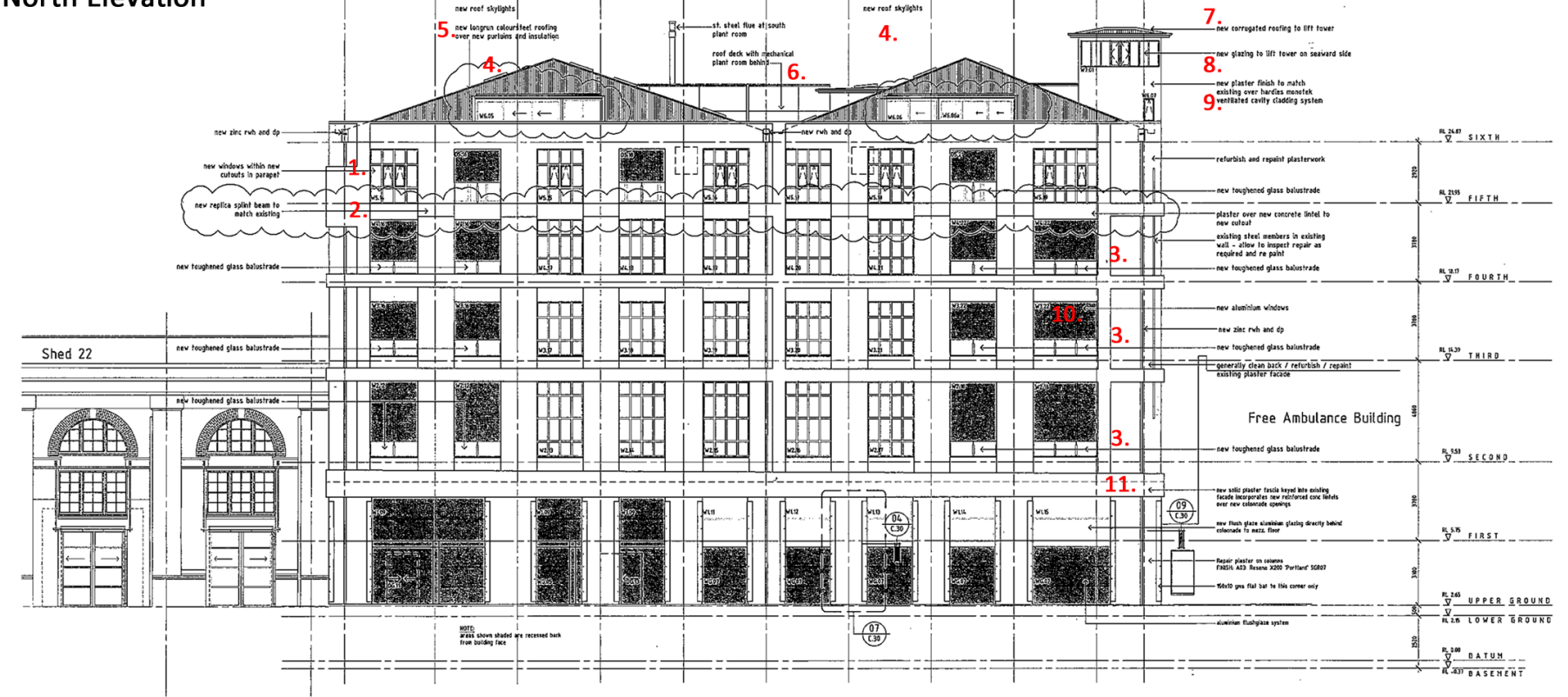

Fig 48. Seaward side exterior facade underwent extreme alteration.

Numbers Referring to Above elevation Diagram

1. New windows within new cut-outs in parapet

2. New replica splint beam to match existing

3. New toughened glass balustrade

4. New roof skylights

5. New roofing over new purloins and insulation

6. Roof deck with mechanical plant room behind

7 New corrugated roofing to lift tower

8. New glazing to lift tower on seaward side

9. New plaster finish to match existing over ventilated cavity cladding system

10. New aluminium windows

11. New solid plaster fascia keyed into existing facade incorporating new reinforced concrete lintels over new colonnade openings.

Odlin's Building: Wellington Waterfront", stated that the,

Odlin's Building proved to be difficult to solve in a way that was economically viable. In the end the decision was left to Lambton Harbour Management Ltd with the only agreement being that its heritage values were to be retained. It was for this reason that an earlier Athfield design, which incorporated louvers on the seaward side of the building was rejected by all three of the appellants. ${ }^{36}$

Di Buchan, the Chair of Wellington Civic Trust wrote a letter 36 Buchanan.D, Chair Wellington Civic Trust. Submission to: Waterfront Development Sub-Committee Proposed Refurbishment of the Odlins Building:Wellington waterfront. 7 Oct 2003. Web. 16.7.11 to the Wellington Waterfront regarding decisions related to the conversion of Odlin's, stating,

\begin{abstract}
The proposed Athfield design gives little cognizance to the heritage values of this building. On the seaward facade, which is the side most visible to the public, any reference to the building as a waterfront warehouse has been completely removed. ${ }^{37}$
\end{abstract}

The Odlin's Building facade was a matter of great public and council debate. Some considered the proposed changes to the external facades too extreme and altering the original framework, while others believed it enhanced its historic past. The City Council's planning department had advised the Wellington Civic Trust that the proposed changes to the seaward facade of Odlin's Building were minor and met the Waterfront Framework criteria. Others felt the work done on the seaward side would destroy the adjacent buildings bordering Odlin's by “obliterating heritage detail from the central and dominating unit of the three". ${ }^{38}$

Athfield Architects stated that their design had connections with the building's former use. The two existing entrance points within the building were located on the seaward side and the commercial street side. Timber would come into the building's seaward opening from the water's edge where it was unloaded. The insertion of the public walk way and the opening of the colonnade was a decision by the architects that acknowledged the building's former use.

\begin{tabular}{ll}
\hline 37 & ibid \\
38 & ibid
\end{tabular}




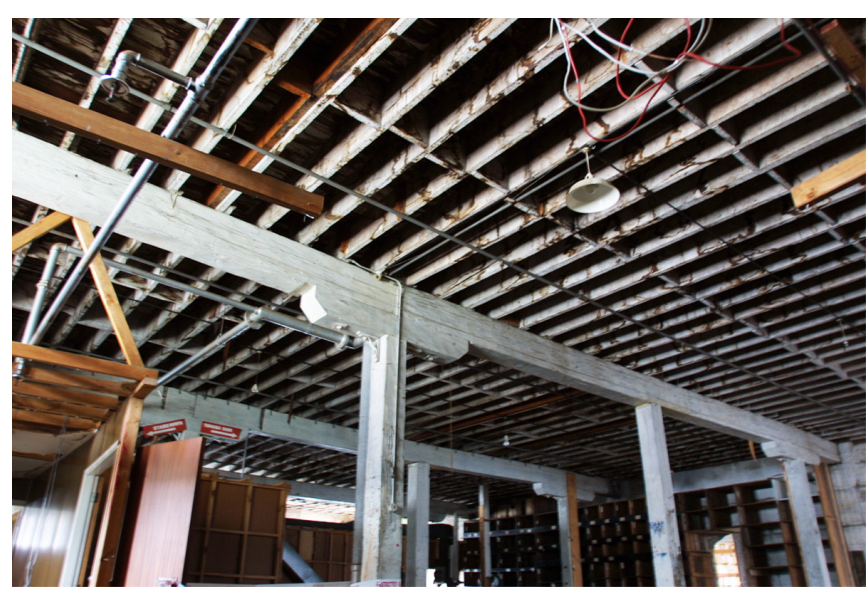

Fig 49. Timber in the ceiling was reused as formwork for the new concrete floors.

The redevelopment of the building still worked for the waterfront by incorporating the idea of bringing the water back up to the edge. Restoring the historic context rather than necessarily the building. ${ }^{39}$

\section{Structural Upgrade}

Prior to the redevelopment an assessment was done by Dunning Thornton Consultants Ltd that assessed the earthquake safety of the building, estimating an,

\begin{abstract}
...approximate seismic performance of the building to be an onset of damage during a 10-20 year return period earthquake in the "across" direction (towards/away/ from the water) and 5-10 years in the "along" direction (parallel to the water's edge). This assumed the walls would remain tied to the floors. As the building was very brittle, it was expected that damage would quickly spread with another set of long earthquakes at this magnitude or shorter ones at up to 2-3 times this magnitude. Failure mechanisms aside from secondary effects (loss of plaster, parapet walls etc), would likely be cracking/crushing of the spandrel beams and rocking/crushing of the brick piers at their base. ${ }^{40}$
\end{abstract}

The removal of the concrete "spine wall" running through the building was proposed. Once this wall was removed it would reduce the seismic performance in the "across" direction to a level similar to that of the diagonal direction. The cost of renovation was also prohibitive for the Wellington City Council. Willis Bond Developers, therefore, purchased the building and their contracting arm, LT McGuiness, renovated it. The entire structure was so derelict that a new building had

\begin{tabular}{ll}
\hline 39 & Athfield. Z., and J. Hardwick-Smith Personal Interview. 11 November \\
2011 & Dunning Thornton Consultants Ltd, Odlin's refurbishment: Existing \\
40 & Structure and Construction Hazards. Wellington City Council. 15 Aug 2003
\end{tabular}

60 to be built inside the old facade, which was also substantially altered. Complications meant that thousands of litres of water an hour had to be pumped out at high tide. ${ }^{41}$

Contractors were literally swimming since the basement was submerged under $1.5 \mathrm{~m}$ of water. An additional challenge to this was because construction was below sea level and required meticulous planning in dealing with tides. ${ }^{42}$

Strengthening was stated to involve between $\$ 1 \mathrm{~m}$ and $\$ 3 \mathrm{~m}$ before a temporary permit could be issued for use of the building. ${ }^{43}$

The statement below was published by the Wellington Waterfront Framework,

\begin{abstract}
Restoration of the building will be a major construction project in its own right. It will involve full earthquake strengthening, and rebuilding to the extent that there will effectively be a new building constructed inside the outer shell of the existing building. ${ }^{44}$
\end{abstract}

The building was primarily strengthened with a series of moment resisting frames made from concrete and steel columns and concrete floors. These were used to make the joints or connections rigid, i.e. these structural elements were designed to be strong in bending. Because so much of the building was rotten internally due to water damage, the building had virtually to be rebuilt on the inside.

Thus the engineers, Dunning Thornton and Athfield Architects faced a big challenge due to the bad state the building had been left in after years of dereliction and vacancy. Structural work and repairs began in January 2004, and once the framework to support the building was complete, work on the assessment began. The former warehouse and factory did not meet earthquake safety criteria. Due to significant water damage and subsequent rot, much of the existing structure and floor plates were unsalvageable. However, in the conversion the architects used as much as possible of the salvaged timber in the underside of the ceilings and for decorative wall panels in communal areas.

The large floor joists were reused in areas which would be particularly visible from the exterior. ${ }^{45}$

Similar to Shed 21, polystyrene filler was also used in the modification of Odlin's (refer to figure 52), primarily to the

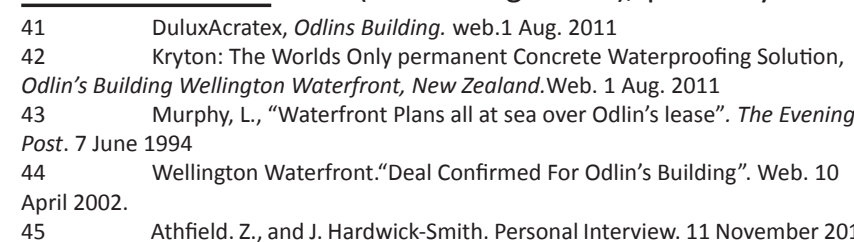


Trusses in the roof were removed. Skylights inserted and deck areas revealed

\title{
Addition of new lightweight parapet
}

New levels shown in red; first and sixth floors
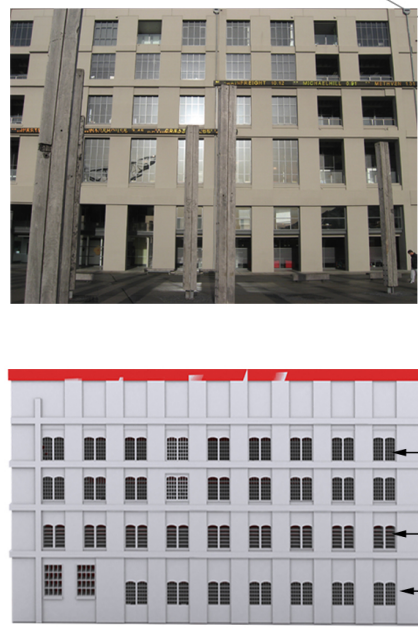

\author{
(n)
}

(1)
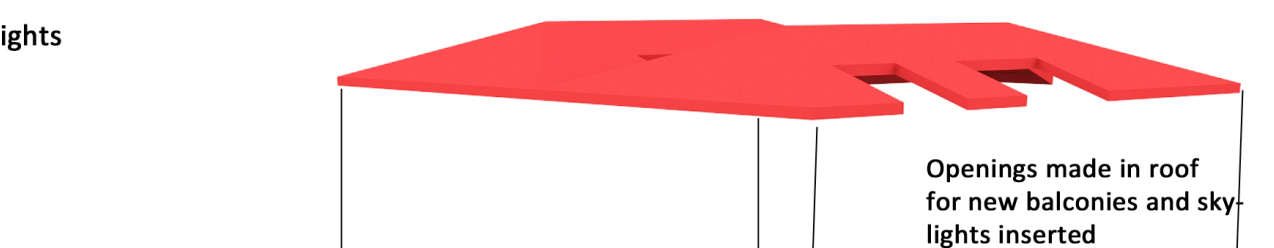

for $n$ of existing parapet demolish for new structural beam

$\leftarrow$ New windows inserted

New mullions, small windows combined to make one large one.

New cutouts formed to accommodate new balconies

Windows and portion of wall removed to form colonnade for new balconies and skylights inserted

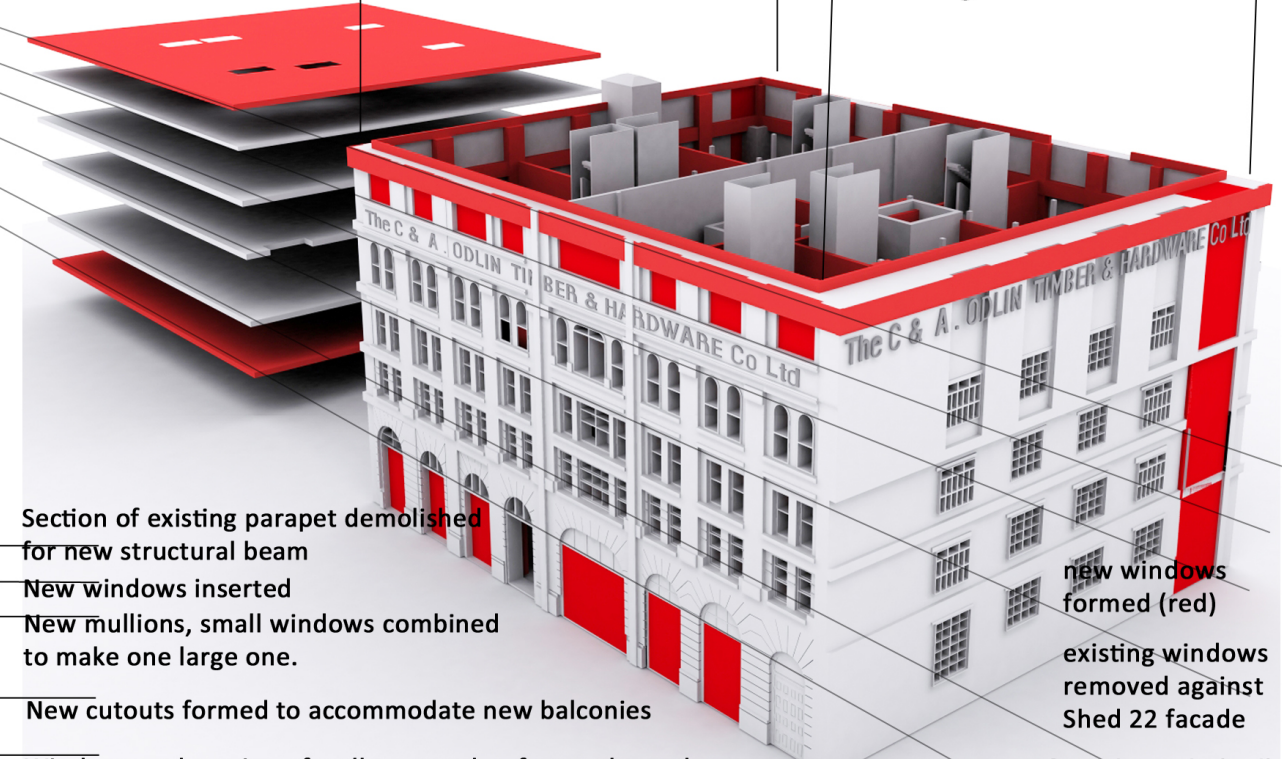

opening for colonnade (red) ground level

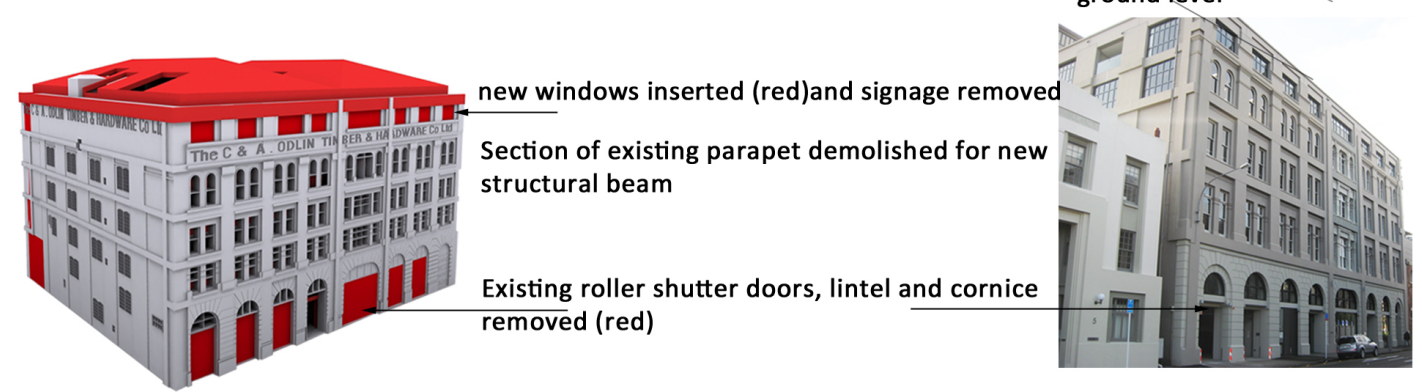

Trusses in roof were removed to create space for mezzanine level (apartment area)
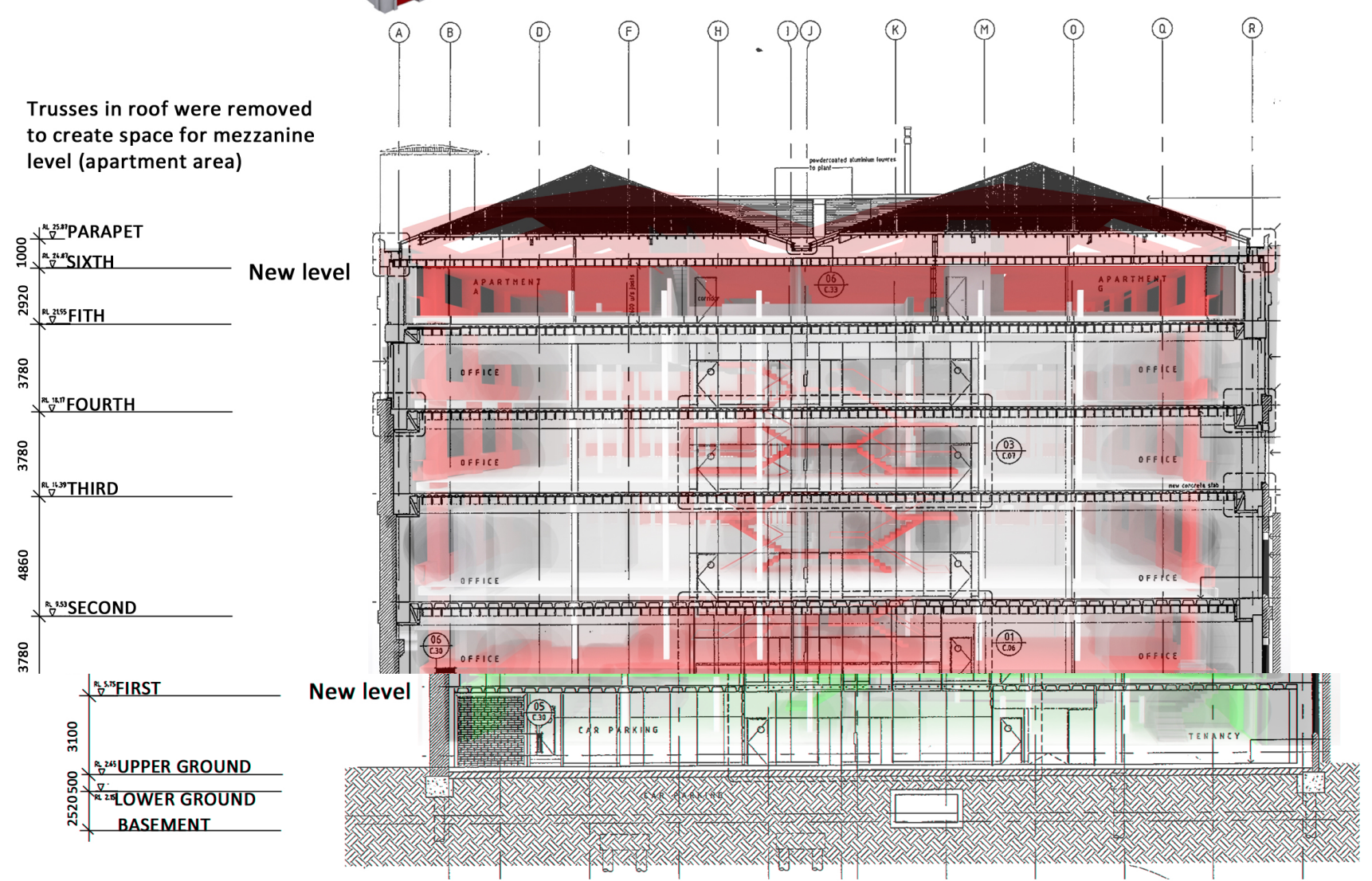


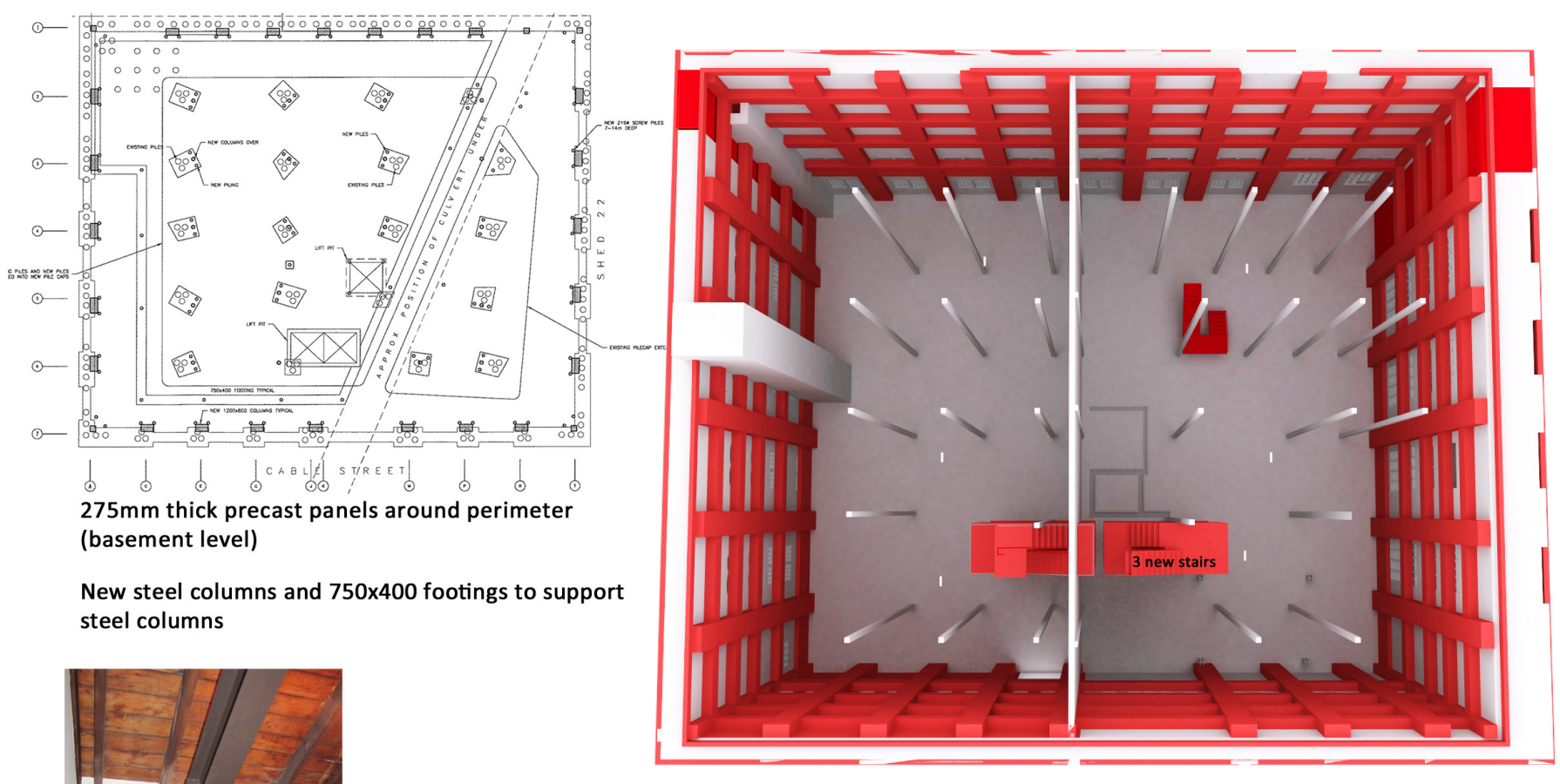

Concrete edge beam $400 \times 400 \mathrm{~mm}$ around perimeter to assist steel columns in shear loading integrity

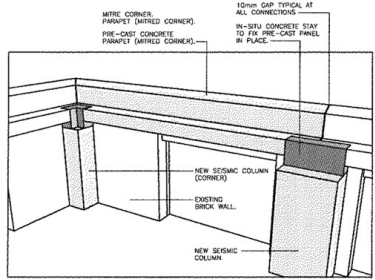

PERSPECTIVE SKETCH OF PARAPET CONNECTION

mon 10 sours

Parapet Connection. Precast concrete,

mitred at corners. New seismic columns at corner

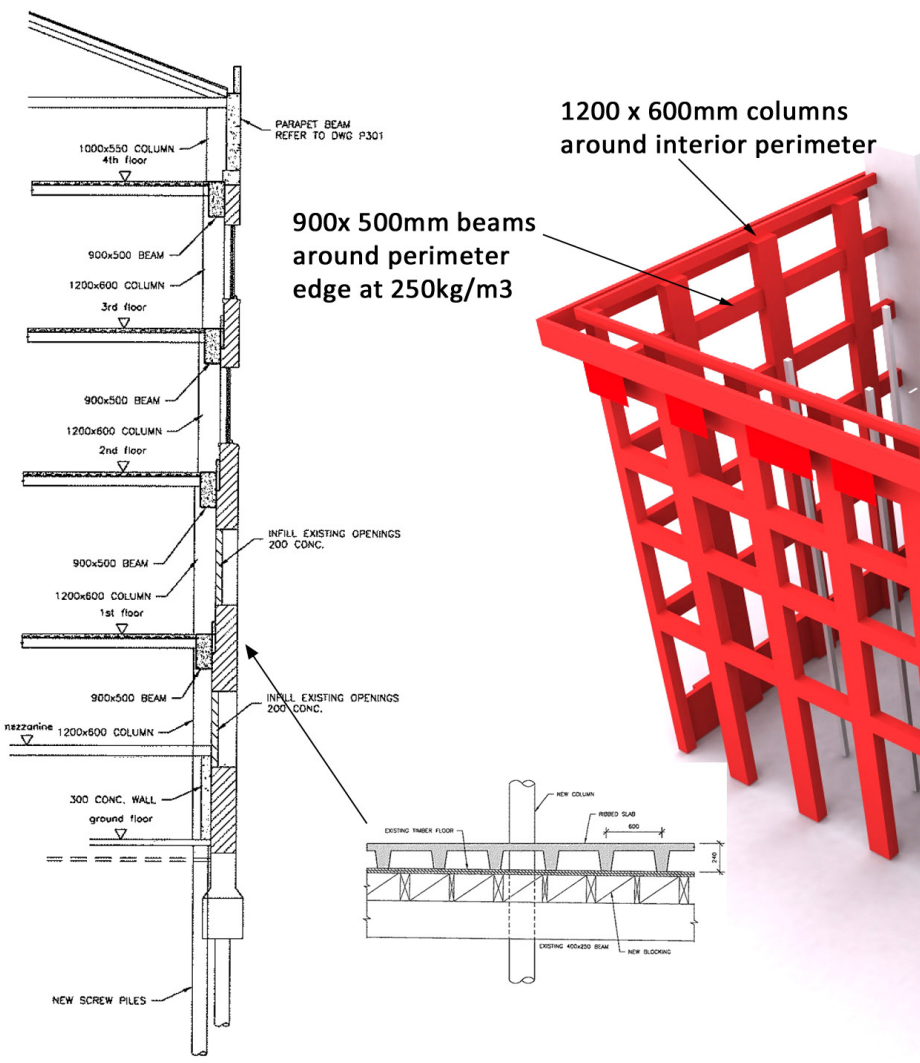

Additional Internal Strengthening Structure:

Moment Resisting Frames

All internal, walls, fixtures, stairs lift casing plumbing removed
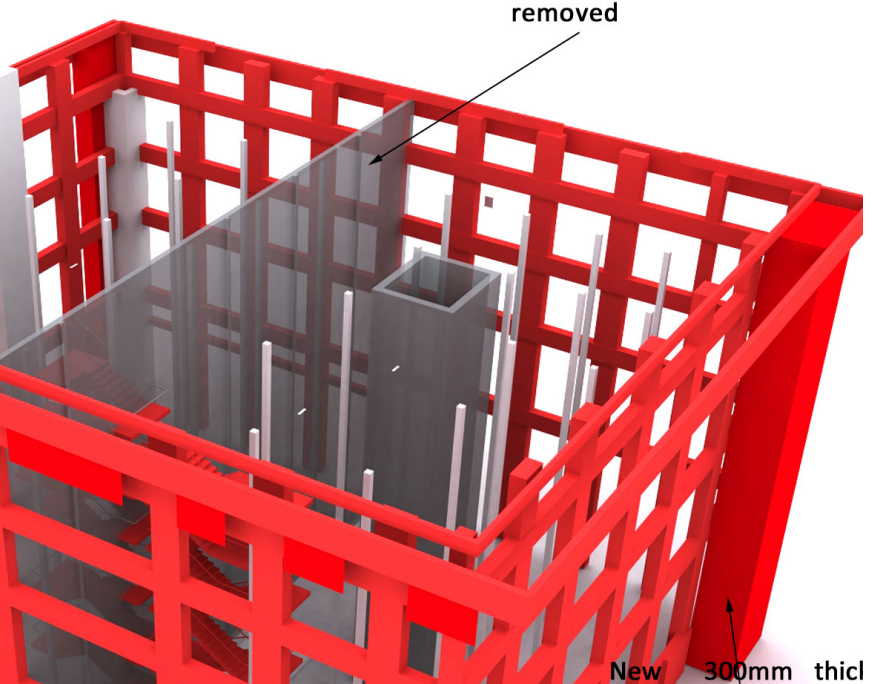

concrete slab was cas over existing timbe floor, attached witl grouted starters intc the brick wall face anc new trimmer joists.

Addition of $250 \mathrm{~mm}$ thick insitu concrete wall up to mezzanine level 

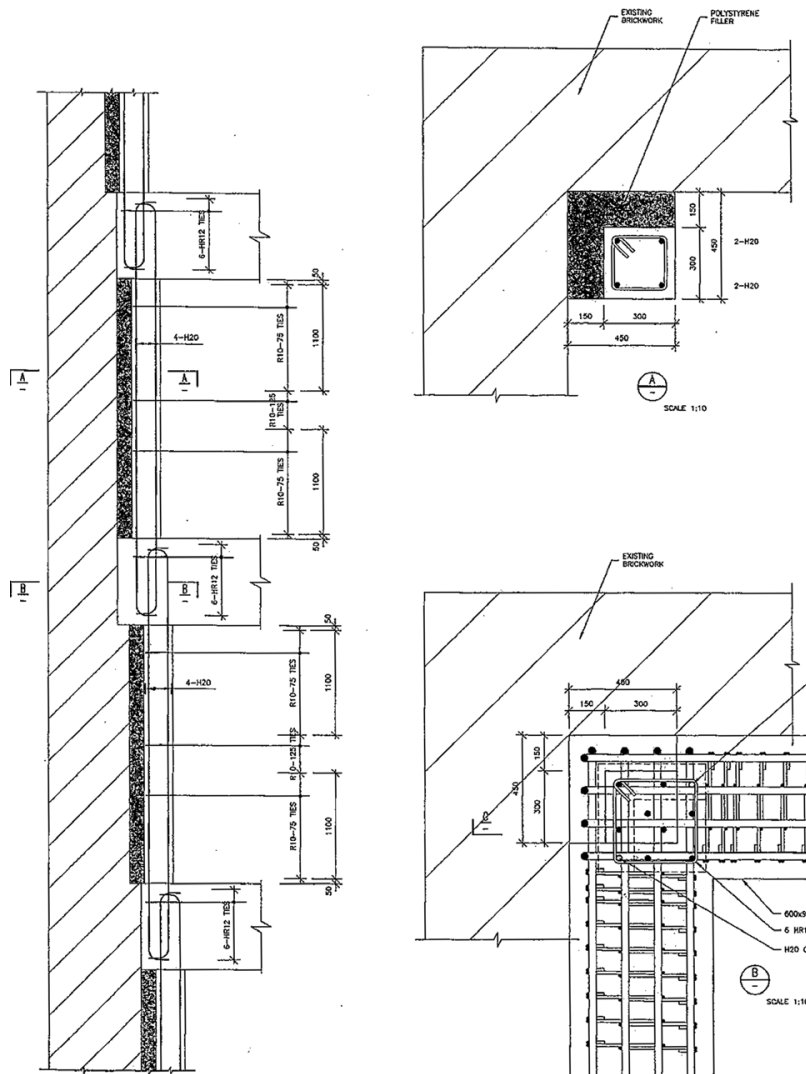

CORNER COLUMNS
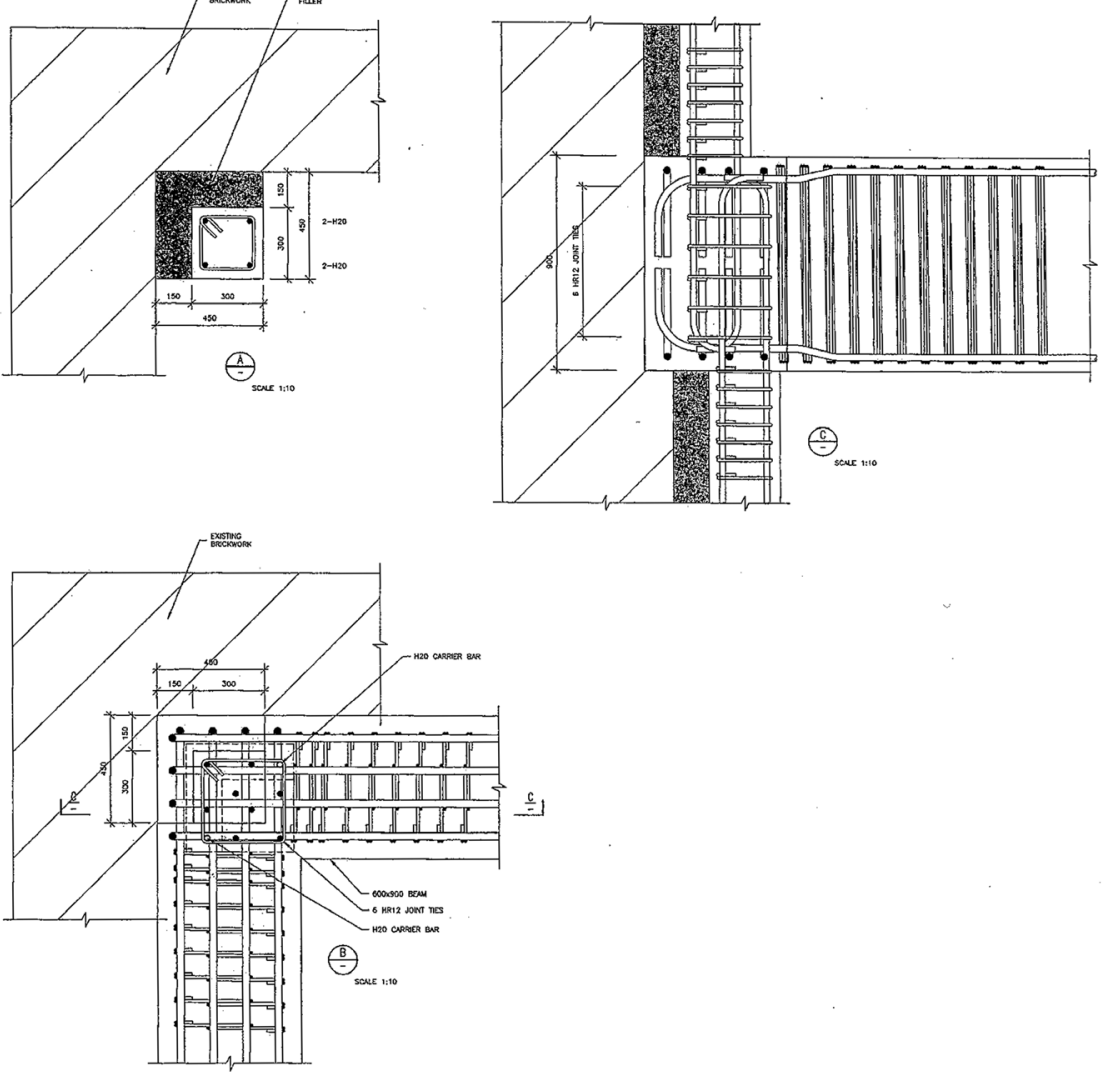

NOTE NARS RUN CONTINUOUS

Fig 52. The image above was a drawing done by Dunning Thornton illustrating the Polystyrene filler that was inserted around the perimeter of the buildings shell, between the existing brick wall and the new concrete.

internal side of the brick wall, as a separator between the brick and the columns, and as a stiffener to PFC (parallel Flanged Channels). The moment resisting frames were inserted around the entire perimeter of the building on each level. These provided a complete space frame throughout the building to carry vertical loads, and resist lateral forces. ${ }^{46}$ New columns and beams were inserted at each level as well as new concrete floor plates laid over the top of the reused existing timber floor. ${ }^{47}$ A new concrete frame was inserted at the basement level.

As well as these changes, an additional $250 \mathrm{~mm}$ thick insitu concrete wall was inserted that went up to the mezzanine level. Walls below the roof space mezzanine level were lined with ply for bracing, and to help against shear forces. $1200 \mathrm{~mm} \times 600 \mathrm{~mm}$ full span columns around the interior perimeter were inserted. Seismic columns were inserted at each corner. Seismic frames ran up the internal wall of the building, spanning its full height. A $400 \mathrm{~mm} \times 400 \mathrm{~mm}$ concrete edge beam (refer to figure 51, upper plan section render) was inserted around the perimeter to assist the steel columns in shear loading integrity. Because the building was in such bad shape, and so much of it had to be gutted from the inside, new piles as well as existing ones were tied onto piling caps.

Odlin's warehouse and factory had the most change, but also \begin{tabular}{ll}
\hline 46 & Applied Technology Council. Built to Resist Earthquakes. Web. 20.8.11. \\
47 & Athfield Architects, Odlins Building. Wellington. C 2005. CD
\end{tabular} the least amount of existing textural quality when compared with Shed 21 and the other conversions covered in this thesis.

The Historic Places Trust required the redevelopment to retain the historic character and aesthetic quality of the building, however the conversions of Odlin's severely altered the original architecture and structure, especially on the exterior seaward side.

The biggest change to the facade was the demolition of part of the seaward facade wall to include a colonnade, again for public thoroughfare. Another large modification was to the existing windows. Several were removed completely whilst all the windows on the water side were modified from semi arched ones into large rectangular ones. The result was interesting, as they lost the architectural embellishment but gained an industrial look that they did not originally possess. The removal of the architraves, roller doors and wall linings significantly modernised the embellished originality of the exterior. As Athfield Architects stated,

...it was also something that the heritage body did not put as much value on. Odlin's Building was more about the scale and bulk, the general appearance. Values were not recognised in the intricate facade,...less pressure on finer detail. ${ }^{48}$

$48 \quad$ Athfield. Z., and J. Hardwick-Smith. Personal Interview. 11 November 


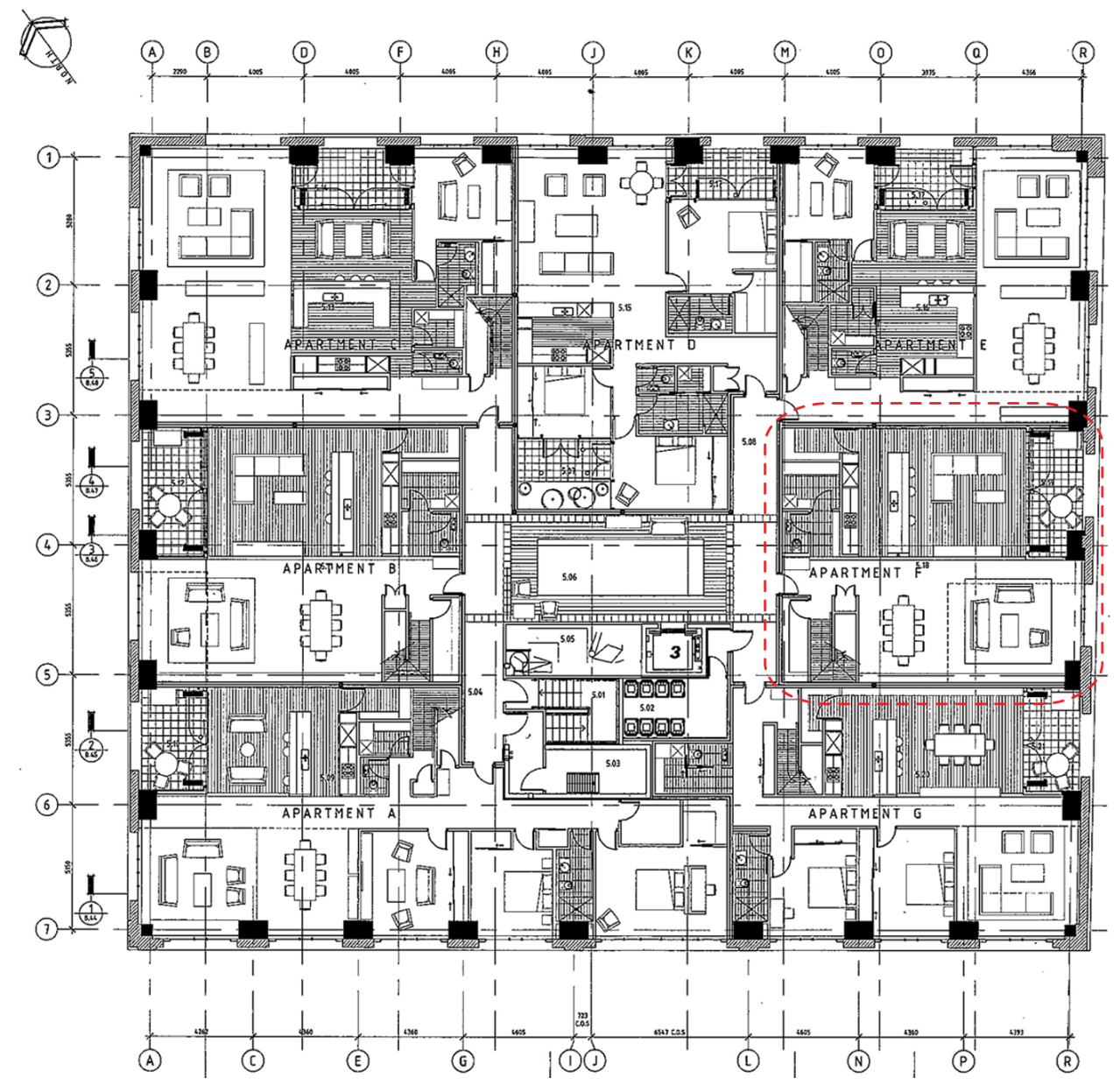

Fig 52b. Apartment layout showing lower level. Apartment 4F, circled. The layout was circular around the central common lift and stair.
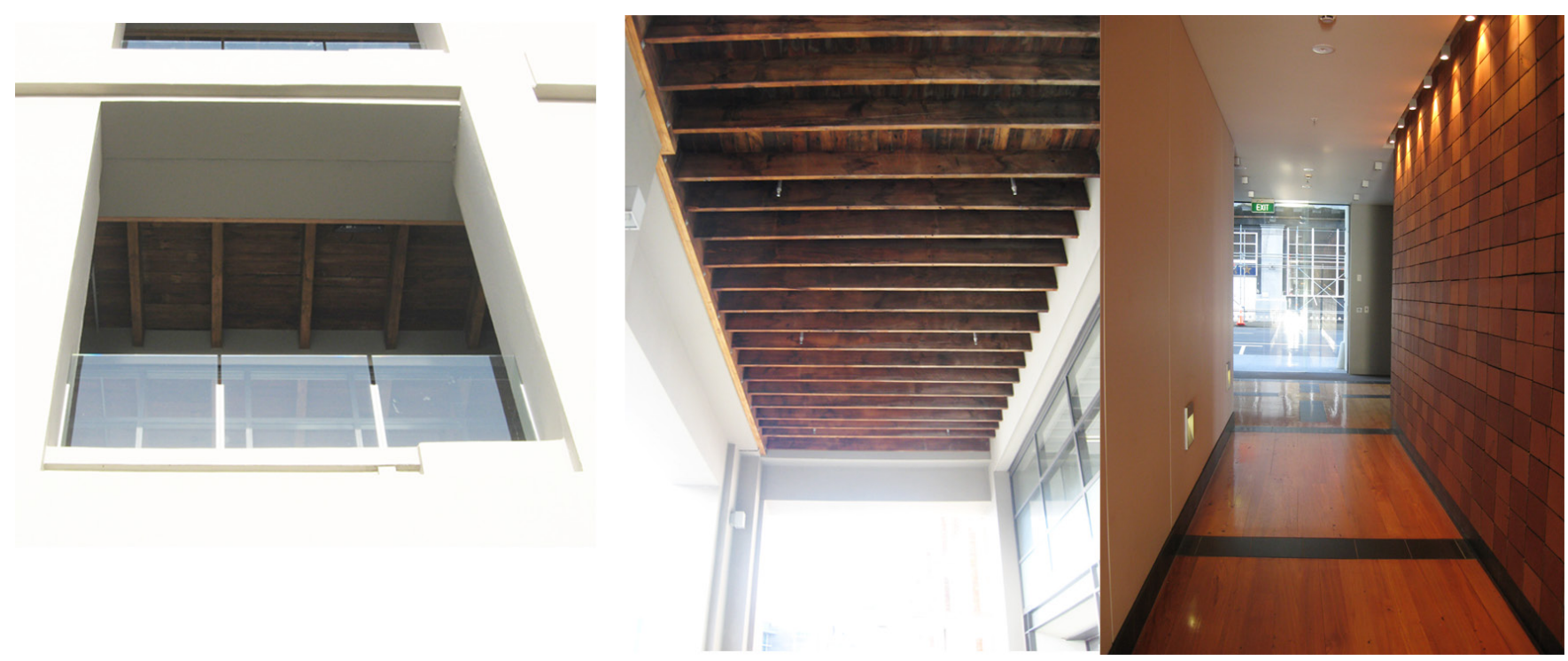


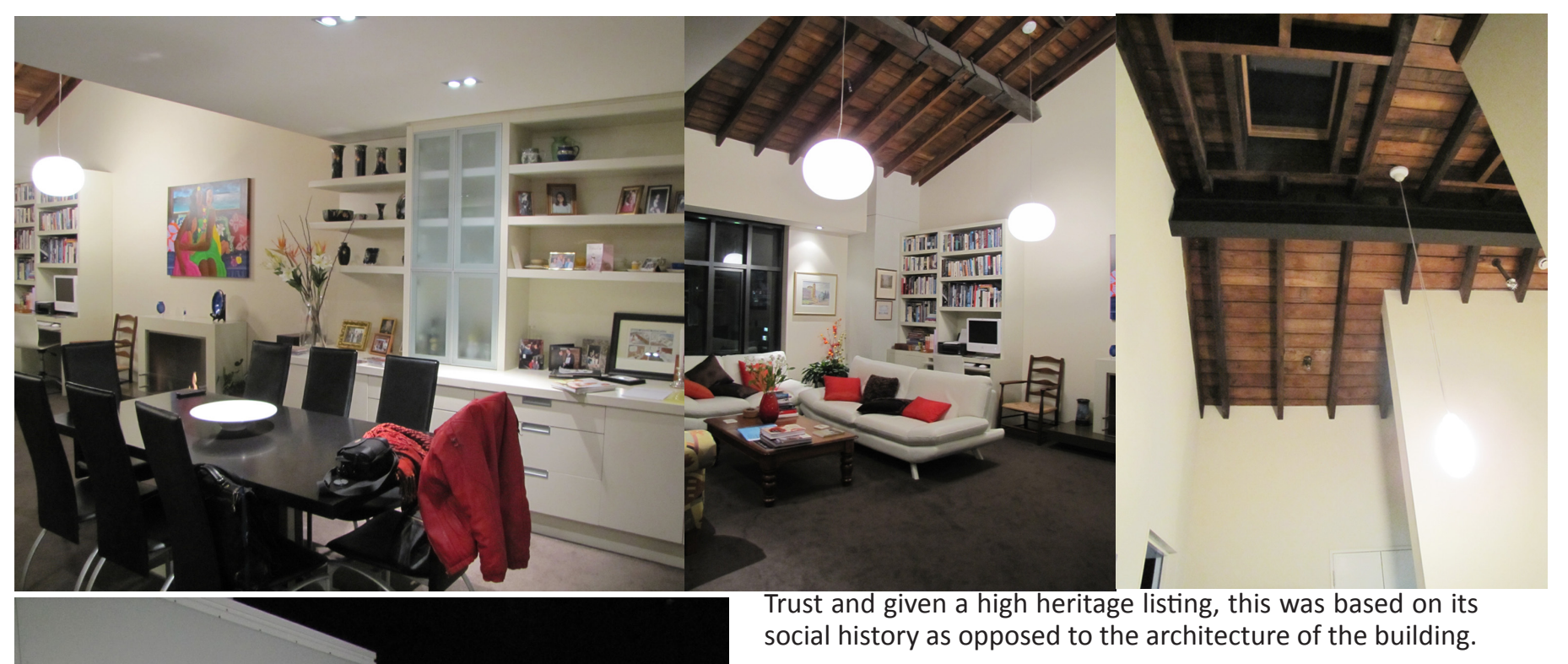

As the architects had stated, the conversion was more about preserving the scale and bulk; and the general appearance as opposed to valuing the finer details such as the facade. ${ }^{49}$ Of the four warehouse and factory buildings analysed in this thesis, Odlin's has the fewest qualities that would suggest it was a converted warehouse or factory space. Internally is not unlike a modern apartment block and has few qualities of age, or original materiality and layout. The salvaged timber which was used as form work for the new floor, left exposed in the ceiling joists and the decorative panels in the ground level foyer (Fig 53) were reused existing materials, reflecting some of the building former character. It was clear in the outcome of this building that the new forms were not directly influenced by the existing structure or materiality, due to the limited evidence of similarity and reuse of existing elements or connection to them; neither symbolic or architectural reference was evident in the reuse of this building, therefore the modification of this building could not be called a preservation or restoration but was more a complete remodelling. ${ }^{50}$

The existing external green-hued colour prior to the conversion (Fig 47) was repainted cream. The replacement of original timber and/or steel mullions with aluminium ones and the modification of the seaward side windows was a decision on the part of the architects and the developers. This was attributed both to economic costs and the developer's strong position on maximising the views. There was not much natural light in the middle of the building, so the enlargement of the windows was one solution to aid this.

The Historic Places Trust based Odlin's Category 1 Classification on reflecting important or representative aspects of New Zealand history, and not under the Physical Significance category or Cultural Significance. Although this building was assessed by the New Zealand Historic Places The architects stated that aluminium was also chosen for its durability, lower cost and easier maintenance in the future.

\footnotetext{
$49 \quad$ ibid

50 Brooker, G, S Stone, Rereadings. 11
} 
The seaward facade was simplified and modernised. The exterior fire escapes were removed as well as the signage on all the external walls, and in their place the New Zealand Stock Exchange electronic banner was inserted, toward which the Wellington City Council contributed $\$ 480,000$.

The roof was modified to form deck openings for the apartments on the top level. New lintel beams were inserted to support the modified roof trusses. The new windows were double glazed for all of the doors and windows surrounding the decks, but the remainder of the windows remained single glazed.

\section{$\underline{\text { Walls }}$}

The intertenancy walls were constructed as follows:

$2 \times 10 \mathrm{~mm}$ Gib noiseline plasterboards were fixed on each side attached onto double studded timber framed wall. The gib walls had a STC rating of 58. Wall vinyl and anodised aluminium UA trim was attached to interior passage walls, together with MDF recessed skirting and Gib sound-seal. Walls near the balcony were water sealed and waterproofed with an air barrier included.

\section{Building Code Compliance in 2003 and 2011}

According to Dunning Thornton Engineers,

The Odlins building was strengthened and renovated in 2003 2004. The term strengthened is really a misnomer in this case as the internal structure was completely replaced with new concrete and steel elements - piles, columns beams and floors. Only the external, heritage brick walls and the roof were retained. The walls effectively went from being the main, load bearing elements to becoming a thick and heavy veneer, well tied back into the new structure. The new structure was designed to the seismic requirements of the then current code NZS4203:1992. Since then, the code has been superceded by the current code NZS1170.5. By comparison of the seismic design coefficients (a measure of the acceleration that the buildings may experience during a code level seismic event), we estimate that the primary building structure should now have a design strength approximately equivalent to 95\%NBS [New Building Standard]. ${ }^{51}$

\section{Fire-Proofing}

The building used concrete floors supported on concrete

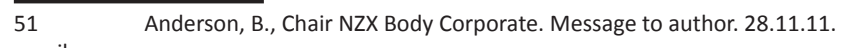
email filled steel columns to separate the building into multiple fire cells. Typically the fire-rated walls in the apartments were $2 \times 13$ fyreline walls on the inside face of the apartment and $1 \times 13$ fyreline sheet attached to ply bracing on the external side facing the corridor. Sound control infill and fire sealant was applied to all floor, wall and ceiling junctions. As previously mentioned the existing walls were lined with $40 \mathrm{~mm}$ of polystyrene insulation as well as a layer of gib. Two fire hose reels, two manual call points, sprinkler risers and charged risers were provided on the apartment level.

\section{Accessibility}

Every resident was granted two internal secured car parks. The public has access to the building from both the seaward side and the Cable Street side. This was the intention of the Architects, as the thoroughfare mimics the original access points. Access to the apartments was both from Cable Street and the waterfront side, and required an access key, as the apartment entry had a separate and private entrance to the offices and other areas..

\section{$\underline{\text { Real Estate Issues }}$}

All seven apartments were situated on the upper floor of the redeveloped building. The apartments had a mezzanine level where the bedrooms were located. They were all pre sold prior to the completion of the building. The overall design and interior scheme of the Odlin's Building was much more conservative than the other case study buildings, due to the demands of Willis Bond Ltd, the developer that marketed the building. The Willis Bond \& Co. Ltd was a well established developer brand, considered a low risk by investors. Their targeted clients were older, with a higher income. Many of these residents already had homes and expected an apartment that would be of a similar finish and aesthetic.

All seven apartments were pre bought from plans and seeing the apartment during the structural change. The buyers knew the work associated with the developer, and thus had preconceived notions of the aesthetic qualities and layout the future apartments would possess. The company's other Wellington example was the Chews Lane apartments, "targeted at owner occupiers, to ensure a real sense of community, the apartments enjoy great natural light, high studs and excellent acoustic insulation." Their website states,

Willis Bond \& Co is a respected real estate and investment company. We are particularly experienced in large, inner-city developments where we aim to create high-quality and vibrant mixed-use environments. We believe strongly in trust, partnerships and creating better communities. ${ }^{52}$

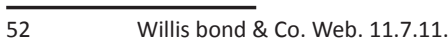


Because the waterfront buildings had a much greater value placed on them, they had to meet higher costs and revenue. The average tender price per apartment was $\$ 1.3$ million in 2003. There was a lot of pressure to gain an economic return; the goal was to have optimum dollar per metre. ${ }^{53}$

\section{Apartment Case Study}

The residents of Apartment $4 \mathrm{~F}$ purchased the apartment in June 2011. The owners are a middle aged working couple who had only seen sketches and plan drawings of an approximate layout, and had only viewed the space when it was still undergoing major construction work. The apartment has living, open office and kitchen spaces and laundry and storage on the first level as well as a balcony. The upper mezzanine level has three bedrooms a walk-in bathroom in the main bedroom, another separate bathroom and balconies on both sides.

\section{Light and Views}

Because little light penetrated into the middle of the building the architects had modified the windows to make them larger and create one window out of two. The apartment level has the advantage of being on the top, and therefore the owners have inserted an additional nine skylights into the roof for extra light. According to the owners, the extra skylights greatly increase the amount of natural light infiltrating the spaces. The apartment has access to two large balconies which accommodate a barbeque and offer impressive views overlooking the water front at the north end and the city centre from the south balconies.

\section{$\underline{\text { Interior Finishes }}$}

The owners had little choice in the interior finishes, as the apartments came with finishes and built-in joinery in both the kitchen and bathroom spaces. The owners picked their own kitchen bench top, carpet colour and made some decisions about minor apartment touches. They inserted their own electric fire place that is interconnected with the heat pump. The insertion of carpet was again something that was advised by the real estate company, based on demographic ideals and preferences. The architects stated the choice of carpeting the floors was due to the acoustic codes being substantially upgraded since the 1994 Hannah's conversion. (refer to Chapter 3). Marketing developers also received a lot of advice from the real estate agents, which tended to be retrospective, based on what has sold in the past and what has not worked as well. The Wellington and New Zealand market is still a relatively immature market, and the Building Code tends to react to problems such as those faced by previous tenants who experienced noise. The 53 Athfield. Z., and J. Hardwick-Smith. Personal Interview. 11 November 2011 current generation of apartment dwellers are used to the norms associated with living in a house in the suburbs. ${ }^{54}$

\section{$\underline{\text { Kitchen and Bathrooms }}$}

Like Shed 21, the Odlin's apartment studied here employed popular materials in the kitchen: melamine coated mdf board, gib and plaster, as well as a steel bench tops. Odlin's includes a pantry adjoining the kitchen space where wine and food is stored, and a wine cellar. The pantry and wine storage show how the planning of the apartment was based around the specific residents' needs.

Spatially, apartment $4 \mathrm{~F}$ is a prime example of a true loft apartment, utilising the roof space with a mezzanine level for the bedrooms. It was however, not designed as a loft style apartment, for the bedrooms are small in size and sectioned off by walls, thus losing the idea of an open plan living/ sleeping area, by still segregating the rooms and activities from one another. Plenty of storage space is included, for clothing and other goods. This allows for things to be hidden away behind doors, as opposed to being left exposed and in the space, as in the original loft apartments. The laundry is also separate, hidden away behind a door.

Apartment 4F is essentially a modern apartment built new, inside an existing heavily modified shell. Very little trace of the building's original structure remains on the inside. The internal walls,as well as the existing internal faces of the exterior walls were gibbed and painted and the same was done to the existing concrete columns. The paint scheme inside the apartment is kept to white shades, emitting a clean simple, modern feel. Carpet covers the newly inserted concrete floor. The bookshelves and cabinetry in the living space are also pre built and appear to be fixed to the walls. They are painted the same colour as the walls and look like a continuation of them. Interestingly there are no curtains or blinds in the apartment.

Perhaps this is because the apartments are on the top level of the building and no adjacent buildings overlook them, therefore there is no need for privacy. The interior has a refined polished look with its completely carpeted areas. The existing trusses in the roof space are the most significant part of the original former warehouse. The roof had several alterations including insertion of skylights and accommodation of new balcony areas, new roofing and purluins over the existing sarking, however, the existing beams and joists were reused and left unpainted. The living room has a double height space sectioned off where the roof is visible from the lower level of the apartment, as well as in the mezzanine level.

$\overline{54} \quad$ ibid




\section{Conclusion}

The vast amount of strengthening work that was put into the building makes it harder to establish whether this project was a success in terms of economics. The significant level of change to the architectural style and aesthetics, particularly in the exterior, also diminishes the building's historic importance, as the redevelopment failed to preserve some of the most significant existing features, modernising the building to an extreme level. The original Edwardian style has been diminished, particularly with the replacement of windows, and sanding back of the plaster. The addition of new materials such as the aluminium mullions also seem a less fitting choice against the existing timber window frames.

The industrial character of the building and its original historic framework was not preserved to a significant standard, although this was in part dependent on the poor state of the building, and its having been left derelict for so long. This disadvantaged the buildings conservation and heritage with the removal and replacement of several imminent elements, materiality and configuration as well as the symbolism of its original nature and characteristics.

Internally the apartments were essentially constructed from scratch and a new mezzanine level floor was inserted with the additional space acquired through the removal of the roof trusses. The columns within the interior were covered by gib and plaster, hiding any trace of the rough, industrial unfinished look that is associated with warehouses. The finished look is clean, conforming and pristine, with carpet covering all the floors. There was nothing left for the resident to do or fix up themselves, everything was finished and decided for them, from the layout of the rooms to the storage spaces provided.

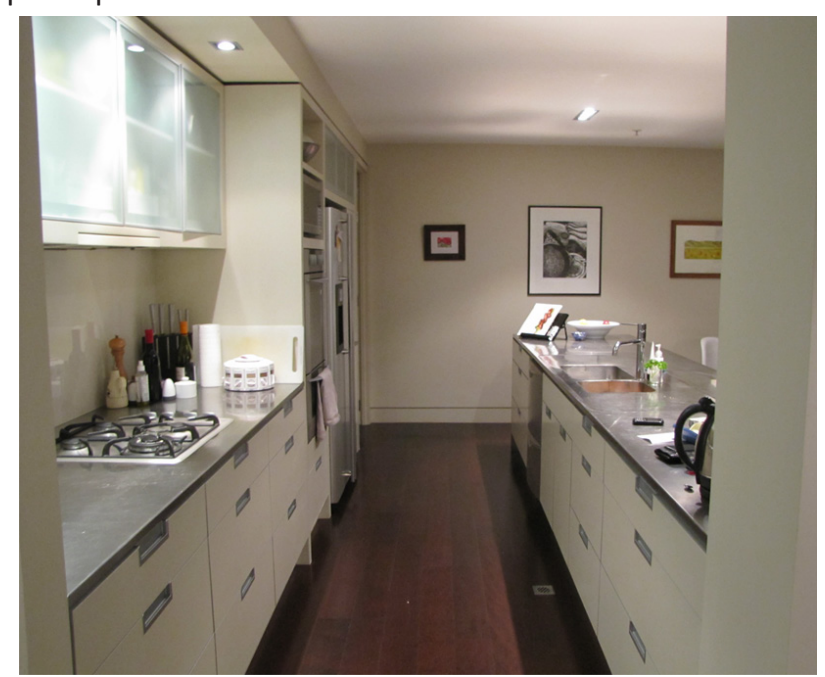

The kitchen used modern finished and joinery. Steel top benches and plastic coated MDF joinery, resulting in a modern apartment look.
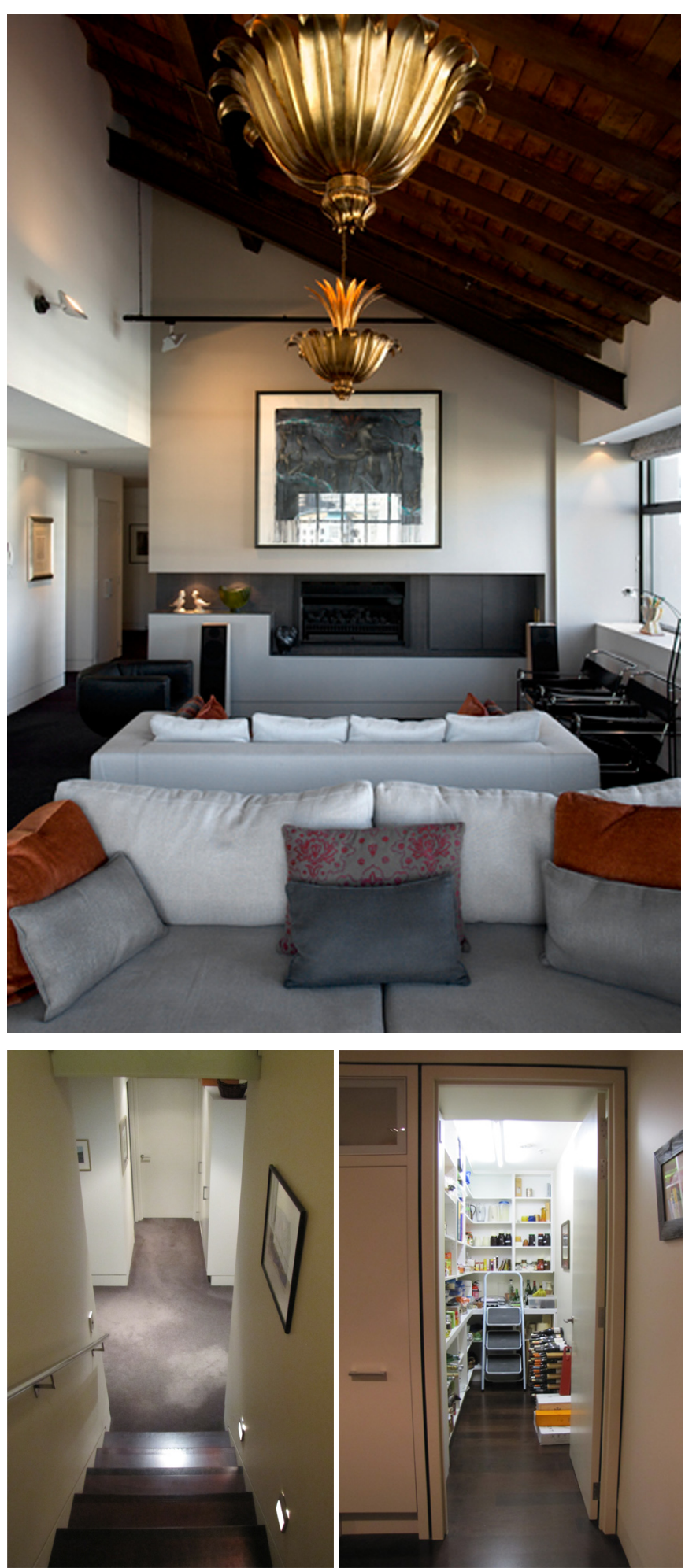

Top images-exposed existing timber joists and beams were reused in the apartments. Floors were finished in a carpet throughout the living and bedroom areas, excluding the kitchen. Pantry visible beside the kitchen area. 


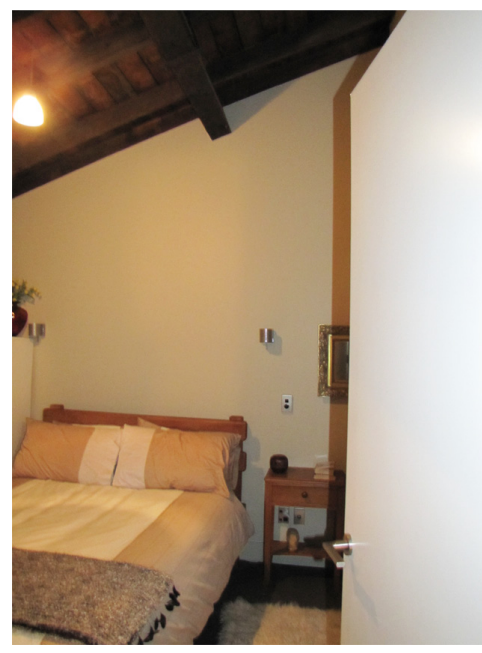

Bedrooms were generally small with a walk in wardrobe and partitioned off. Each bedroom had a balcony patio area.

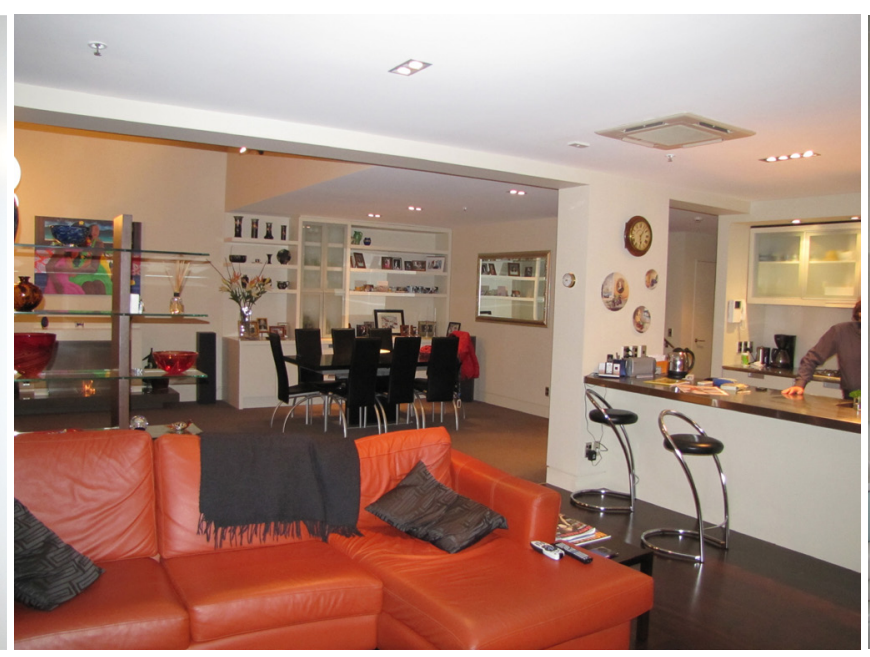

Part of the ceiling was left exposed whilst the rest was plastered and painted, with the down lights fitted inside. These spaces lost the double height floor to ceiling span.

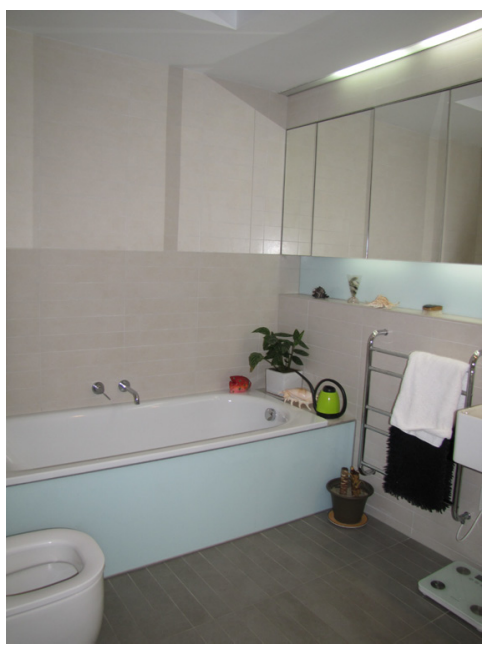

The bathrooms also used modern material and finishes with cabinets built in to the walls, and tiles for the floor.

The approach taken in the conversion of the Odlin's Building was less successful in terms of its historic preservation, especially when compared to the earliest loft conversions and their evolution from an industrial building to one of residential use. The approach taken for this buildings conversion can be described as one of remodelling, where the building was altered in its entirety. The function was an obvious change, but upon conversion the building lost links to its former programme, both architecturally and in terms of connection to its history. 
03:

Street, Te Aro

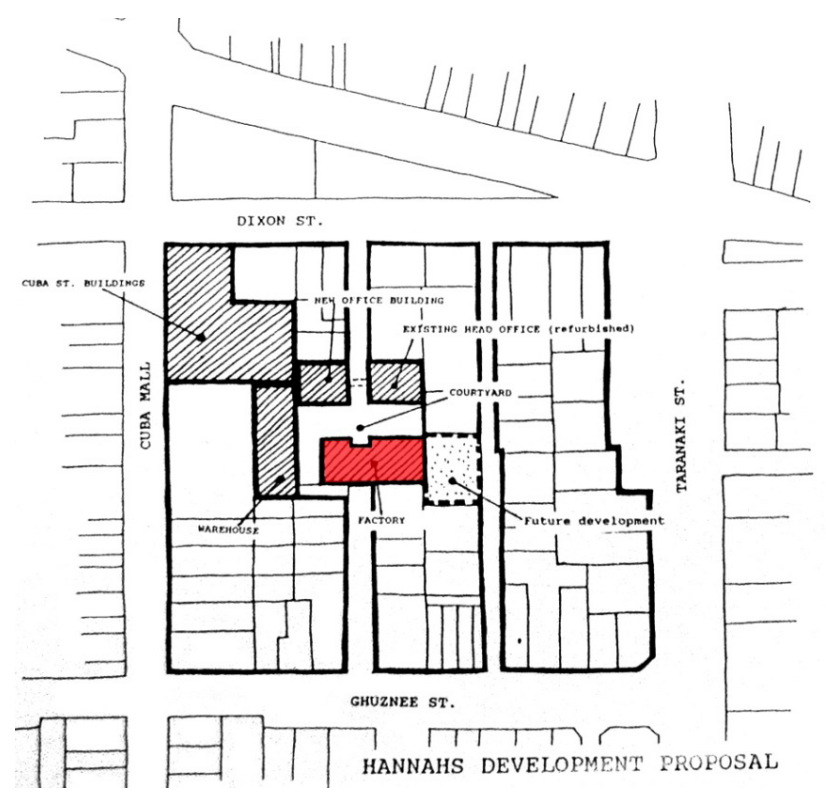

Fig 55. Hannah Block, highlighting the Hannah Factory new thoroughfare was established directly through the factory with access from Ghuznee St to Dixon. St. The access way is regulated at night to keep the night time activity and noise to a minimum in this area.

The first building discussed in this chapter that forms part of the Hannah Block, is the Hannah's Factory, situated at 14 Leeds St, Te Aro, Wellington (Fig 1). This former boot factory once belonged to Robert R. Hannah of the Hannah shoe company. Robert Hannah was born in County Antrim, Ireland and came to New Zealand in 1866. In 1874 he made the move to Wellington from where he established a series of footwear stores across the country. By 1893 Hannah had 10 shops and a factory employing more than 250 people. By the start of 2000, Hannah's had dozens of shops, and no longer made shoes in New Zealand, but still remained ${ }^{1}$ New Zealand's best known footwear firm. ${ }^{2}$

\section{The Building}

In 1923 the Hannah Factory was erected by Wellington architect, H.T Johns and built by Hansford \& Mills with a contract price of $£ 23,000$. It followed the building of the earlier Hannah Warehouse, erected in 1909, situated to the west of the factory. According to Victoria Quade, daughter of Helen Tippett, one of project managers and first owners

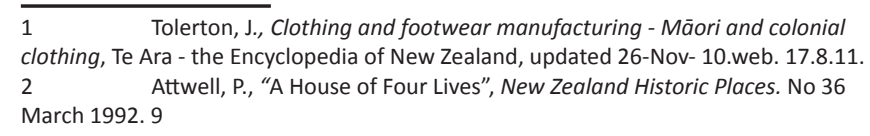

of an apartment in the complex, the factory was built from proceeds earned from supplying soldiers with boots in WW1. ${ }^{3}$

The initial drawings for the building were altered during the planning stage to include an extra storey, an indication of the growth and vigour of this well-known shoe-manufacturing firm. ${ }^{4}$ In 1994 Hannah's moved its distribution centre to Auckland and later the manufacturing operation Footlab Pacific moved out of the factory building to Wanganui. ${ }^{5}$

In 2011, the Hannah Factory remained unclassified and unregistered by the NZHPT. This could have been attributed to the fact that the building was never nominated for registration. Nominations can be made by the public or the owner. The city council has their own process for identifying and protecting their local heritage through their District Plans.

The Hannah's Factory was one of several buildings owned by Robert R. Hannah in the Hannah's Block, which included the head office building (circa 1940), the warehouse building 1909 and developments and additions made after the 1980s.

An interesting aspect regarding the architectural and design intent of the buildings within the Hannah Block are their similarities and variations. Although the buildings were part of the Hannah Complex operating under the same ownership their external facades varied. (refer to Hannah Warehouse case study, Chapter 4 for in-depth report). Similarities lie in the internal layout of each building with expansive floor to ceiling heights, and open plan floors, lacking any internal partitioning.

Stuart Niven, the former Wellington City Council's urban designer commented on the similarities within this industrial enclave of buildings.

The buildings derive their character from their
industrial warehousing environment. They
are simple, strong and similar in scale to their
surroundings. Their materials and colours grow
out of the neighbouring building fabric.

Although the Hannah Factory facade was plain and utilitarian, typical of a factory building, a higher degree of external ornamentation and detailing exsisted; particularly in terms of signage and engraving of the main facade (Fig 58). This may have been attributed to the higher importance of the buildings function, as it took over the role of the main factory for production from the Hannah Warehouse.

This variation in status can also be seen with the location of the building, its scale and higher level of detail in the window 3 Quade, V., Personal Interview, 27 Sep 2011

$4 \quad$ Former Hannah Footwear, Wellington City Council.web.4 Oct 2011

5 Shaw, B., "Building saved by boom". Evening Post. 4 June 1996.13 $6 \quad$ ibid ibid 


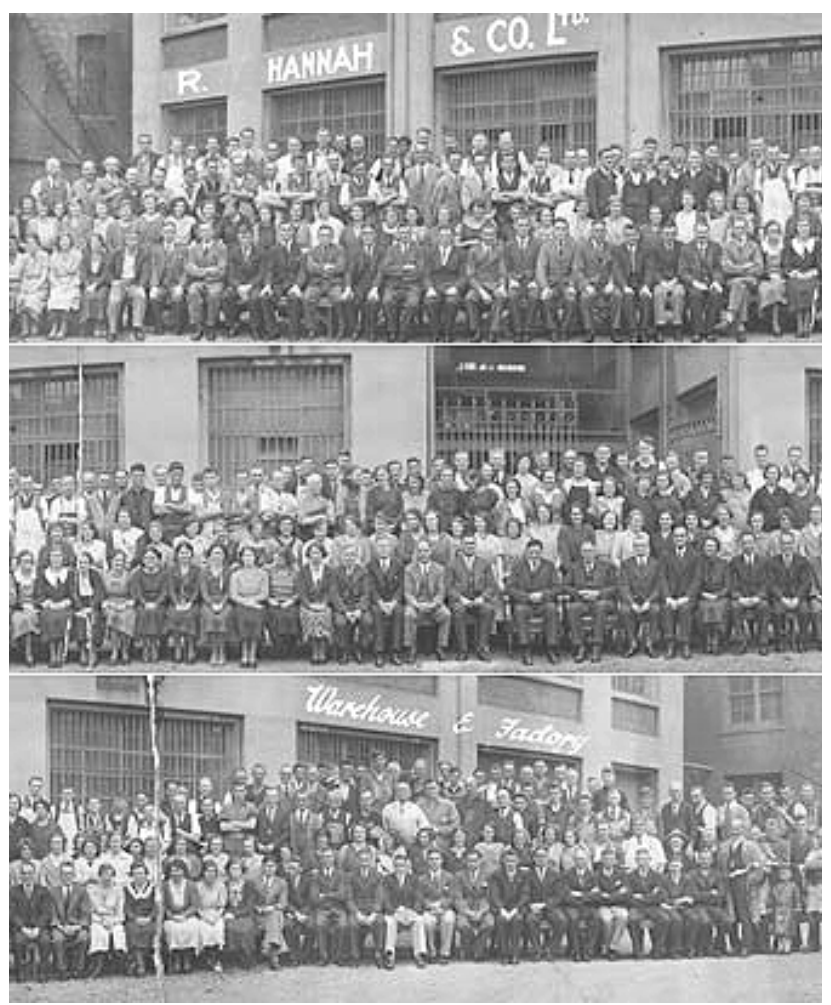

Fig 56. Hannah Factory staff outside the building 1930s.

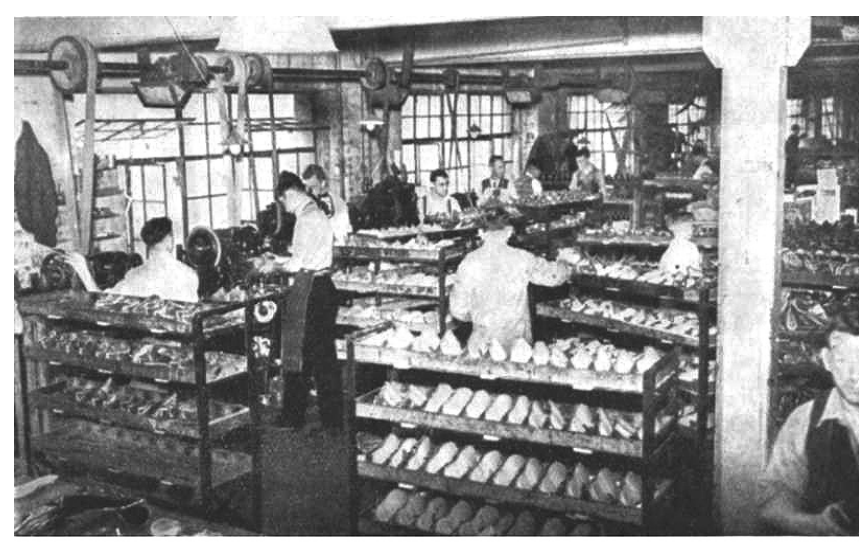

Shoes on trolleys to finishing department, Hannah's, Wellington.

Fig 57. Factory workers placing shoes on trolleys. the large scale windows were a good source of light. Circa 1940

and roof treatment. At the conversion stage the existing lead roofing and roof framing was removed and the existing water tower was modified and reclad with new corrugated galvanised steel to a new timber framed wall and parapet. During the conversion, skylights were also inserted in the roof to allow for even more light penetration.

The exisitng ventilators projecting from the gable roof clad in corrugated iron ${ }^{7}$ also show a higher level of craft and detail (Fig 58). The door remains small and off centre, showing the minimal importance of the entrance. This is similar to

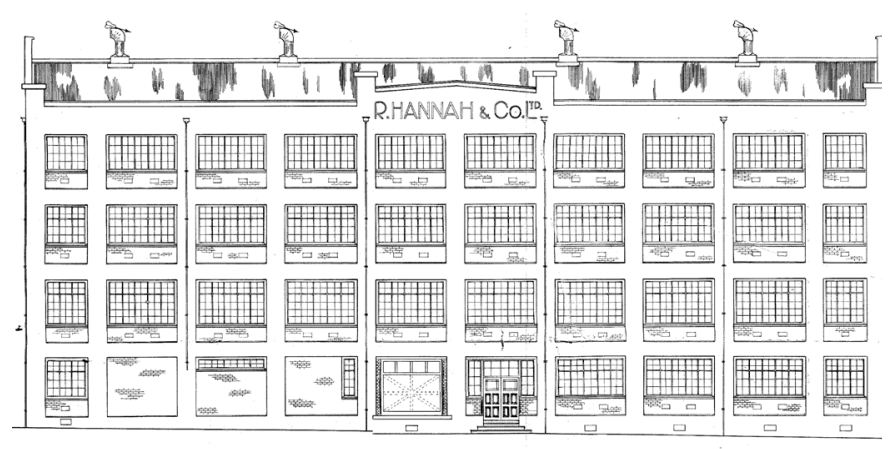

\section{SOUTH ELEVATION}

Fig 58. Existing South Elevation. Signage and ornamentation of the roof is visible. 1927

both Shed 21 and the former Odlin's timber and hardware factory (previous chapters). The interior adhered to a typical uniform layout, with little importance given to the aesthetic of the space, which was separated into 10 bays. The east side had six bays and the west had seven.

The understated treatment of the exterior has been carried inside to provide a series of working environments differentiated by combinations from a limited palette of colours and finishes. ${ }^{8}$

\section{Materials}

The initial construction of the Hannah factory consisted of steel columns and beams supporting timber floors, with exterior concrete walls faced with brick laid in English bond. Internal timbers used for partitions, flooring, and roof trusses were heart jarrah, Oregon, rimu, matai and totara.

From 1880-1930 in urban commercial areas masonry construction dominated industrial buildings. This was partly due to the codes introduced by municipal authorities. Masonry was important during this period as it was a low fire risk. It also meant that a large number of buildings built during this period were unreinforced masonry (URM) (refer to Hannah warehouse Chapter 4). ${ }^{9}$ Due to the buildings existing programme being a manufacturing and commercial one, upon reuse to allow residential acitivity the building had to comply to the Building Code and several changes had to be made to make it legible. These included strengthening for earthquake safety, fire protection and several other changes which will be further discussed in this chapter.

The regular grid of multi-pane windows with mild steel joinery was typical of traditional warehouse design; simple and functional for the nature of the building. Enough light

\footnotetext{
$8 \quad$ Niven, S., "If the Shoe Fits". Architecture New Zealand November/ December 198936

$9 \quad$ New Zealand Historic Places Trust, Earthquake Risk BuildingsRecommendations and Guidelines for classifying, Interim Security and Strengthening, 3 March 2009.26. web. 3 Oct 2011
} 


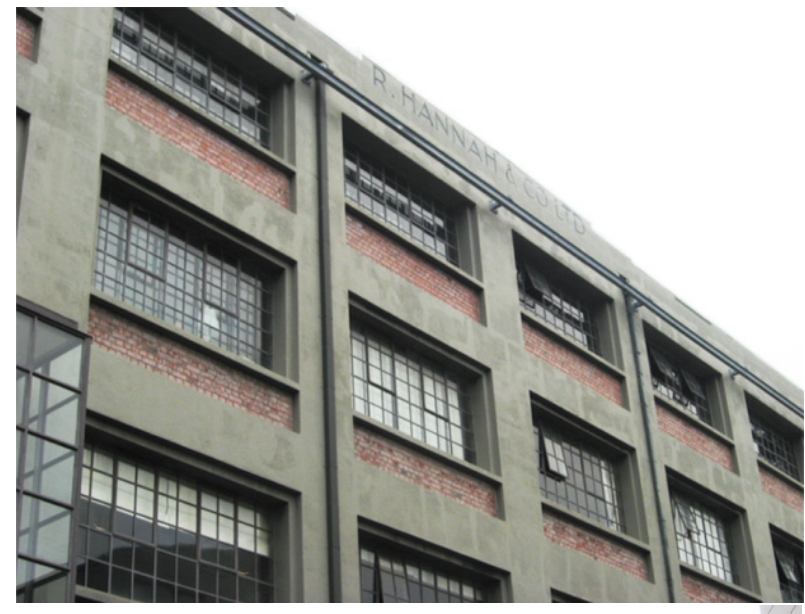

was able to infiltrate the space for workers to do their factory work. Spandrels were brick infill (Fig 5), and the building was capped by a low parapet which stepped up over the centre. The architecture was functional as described by the WCC Heritage Inventory,

This prominent factory building is a good example of functional industrial architecture where an emphasis has been placed on clear articulation of window openings to ensure maximum natural lighting of the interior. ${ }^{10}$

Like the former Odlin's Building on Cable Street, the heritage value of the Hannah's Factory building became confined principally to the exterior facade, particularly the south face on Leeds Street. ${ }^{11}$

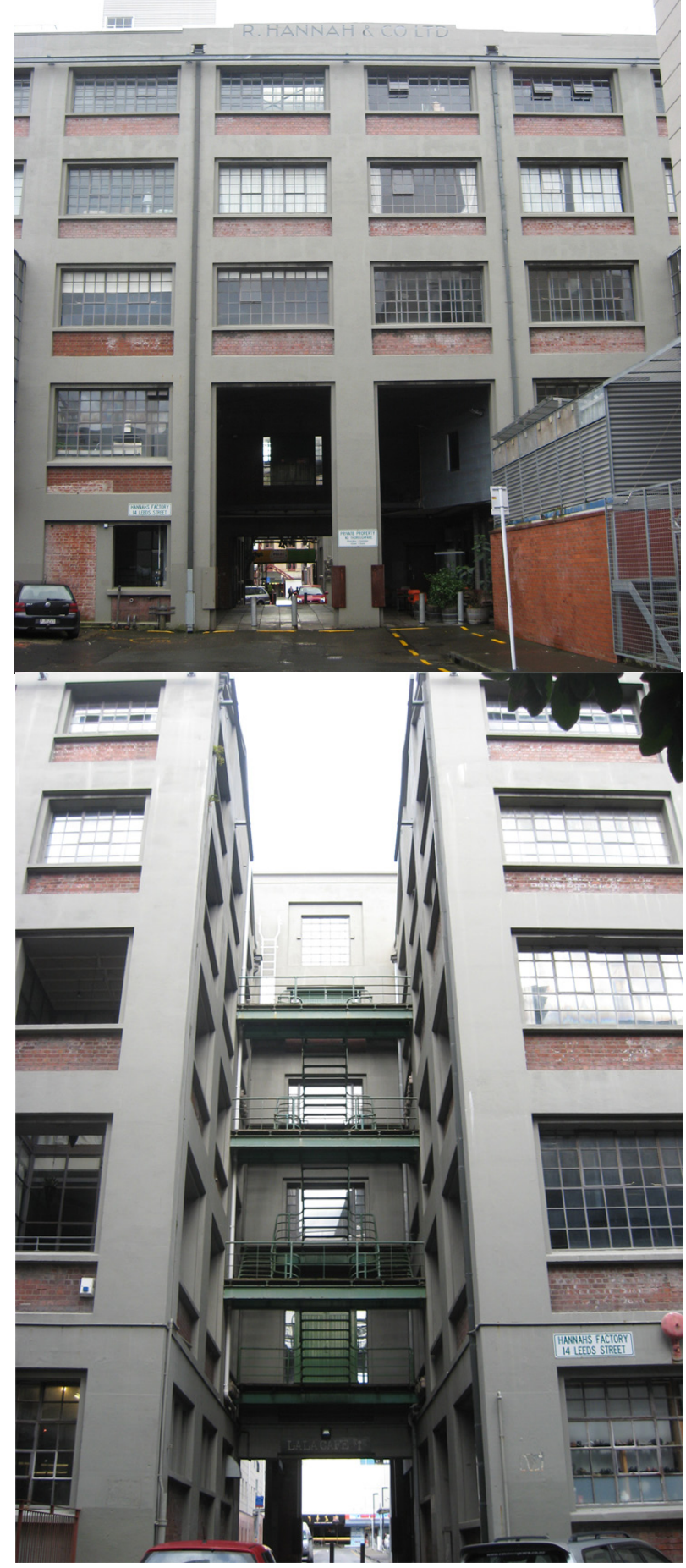

Although the Hannah Factory facade had a higher level of detail and articulation, its plain nature was manifested in an overall uniform and utilitarian expression, unlike examples found in the pioneering lofts of SoHo, New York. In contrast with these, the examples in the Hannah block and the other warehouses and factories in previous chapters were devoid of any decorative cast iron elements on their exterior facades. The Hannah Factory did however have a fire escape that was kept upon the buildings reuse for apartments in 1995.

\section{$\underline{\text { Reuse and Redevelopment }}$}

In 1994, the Hannah factory was bought by Property developer and owner of What's New Ltd, Ian Cassels, who also developed other buildings within the Hannah block. These included the Robert Hannah Apartments, Hannah's Corner Apartments, Atlas House Apartments and Bond Store Apartments. ${ }^{12}$ Excluded was the Hannah Warehouse, which was later bought by separate owners (refer to next case study). No developer was prepared to take all the buildings and after two years of negotiations Cassels purchased the Hannah's Factory building on the basis of an earlier scheme prepared by Athfield Architects Limited for its conversion into apartments. The Hannah factory prospectus stated,

The building incorporates the extension of
Leeds and Eva Streets through the building in
a north/south direction giving access to both
Dixon and Ghuznee Streets. This established
the building in a much larger urban context
enabling the traditional cul de sacs of the area
to be partly eliminated. ${ }^{13}$

According to Cassels, because of the recent economic crash, apartment conversion was ideal, as there was always a need for residential rather than office space. After the success of the first Wellington central city Queens Wharf reuse project,

\footnotetext{
10 Former Hannah Footwear, Wellington City Council.web.4 Oct 2011, 11 ibid

12 Arcus, M. and K, Sanderson, The Rejuvenation of the Hannahs Block: An assessment of the impact of the what's new limited developments on Wellington city, April 2004, 6. Web. 5 Oct 2011

13 Athfield Architects, Hannahs Factory. Wellington. C 1998. CD
}

Fig 59. Conversion into apartments allowed for an opening through the building, creating access from Leeds Street to Ghuznee Street. The walls were concrete faced with brick laid in English bond. 


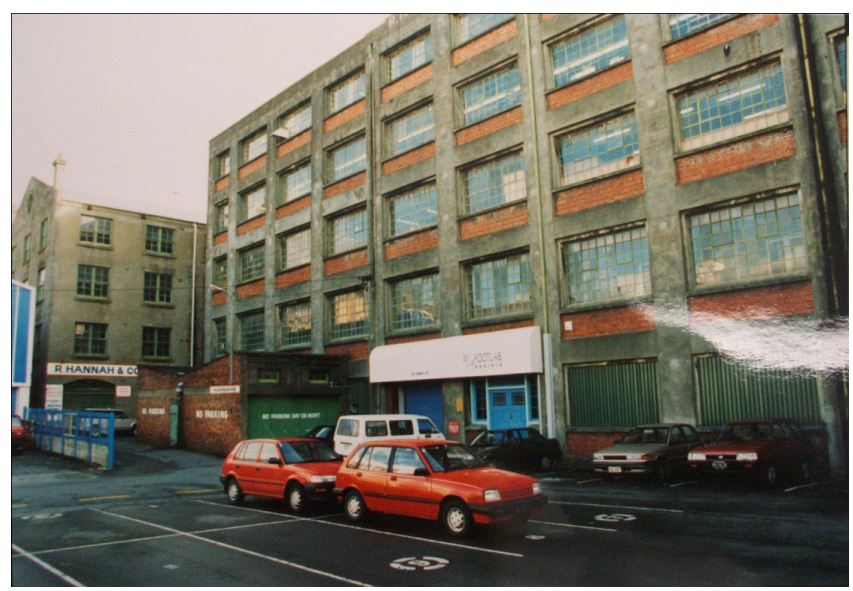

Fig 60. Prior to conversion, circa 1992.

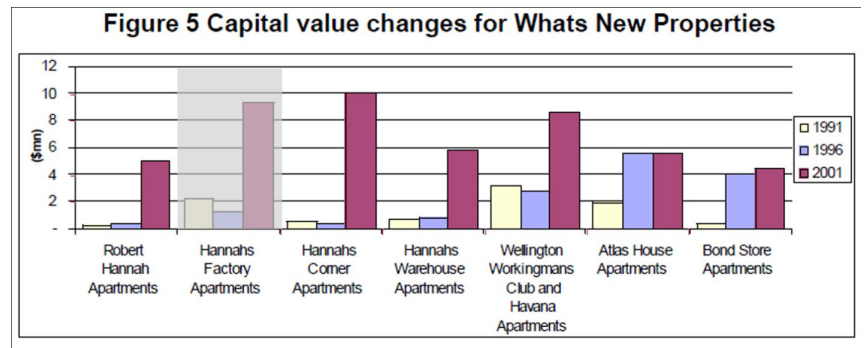

Source: Wellington City Council

Fig 61. Showing the dramatic increase in price of the apartments from 1991-2001, (BERL What's New Ltd report

renovating the former factory seemed like a viable business opportunity. Because of the economic crash, there were also a lot of empty, cheap buildings around the city in the mid 1990s, although Cassels stated the building cost was more than they had set out to make, and in fact the company made less money than they had initially planned. Cassels stated this was due to little competition for apartments from buyers as inner city living was at that point still a relatively new venture. He believed the apartments were sold off too cheaply due to the market only just getting used to the idea of living in the city. A total of $\$ 1,000,000$ was lost on the Hannah factory apartments, with the apartments being sold at half price. Figure 60 shows how the prices of the apartments had increased dramatically by 2001 . This may have been to do with the idea of inner city living becoming more common. ${ }^{14}$

As he stated, ideally a developer would let the market mature before selling, however, because the bank loan had to be repaid pre sales were necessary. ${ }^{15}$ Because the building was located in a former industrial working zone, the council was somewhat relaxed about the rules, and removed the requirement to provide two car parks per apartment,

14 Cassels, I., director of Whats New Co. Ltd. Personal Interview. 12 May

2011

15

ibid although a public thorough fare and space for retail had to be provided on the ground level. Other payoffs of this approach included increases in the use of public transport and people walking to work. ${ }^{16}$

Redevelopment of the former factory in the Wellington City context

In 2004, BERL (Business and Economic Research Limited) conducted an in depth report on the Hannah's Block, and assessed its impact on Wellington city. ${ }^{17}$

According to the report the Hannah Block area trebled in value between 1991 and 2001, going from \$25 million to $\$ 75$ million in $2001 .^{18}$ This redevelopment also encouraged people to live in the city and establish businesses in the area. The population increased from 4 people/ha in 1991 to 28 people/ha in 2001. Redeveloping the former factory into residential apartments was from a business and economic perspective, a viable venture at the time according to Cassels. $^{19}$

The architectural firm involved with the reuse of the Hannah factory and the design of the new apartments was Athfield Architects, with lan Athfield acting as the principal architect and Graeme Boucher as Project Architect. The structural engineering was done by Connell Wagner Ltd. ${ }^{20}$ The Hannah Block redevelopment was designed to rejuvenate the area. The aim was to bring activity back into this part of the city and establish a link between cafes and retail spaces and the inhabitants of the apartments.

Athfield Architects undertook the project with the aim of rejuvenating the Cuba quarter, one of the last old industrial enclaves in central Wellington ${ }^{21}$ and bring life back into this area. Cassels stated that unoccupied buildings, such as the upstairs areas of Cuba Street prior to its rejuvenation, were sometimes occupied by poorly resourced community groups such as community law, or arts groups who paid little rent. ${ }^{22}$

Surveys show the rejuvenation work on the factory helped revive retail and lifted the rents. A council survey showed that people felt much safer in the area and Cuba Street itself was transformed from an area that was "dirty, smelly and where people felt threatened to a place that was pleasant, clean and attractive." ${ }^{23}$ Prior to the reuse of the building,

\begin{tabular}{|c|c|}
\hline 16 & ibid \\
\hline 17 & Arcus, M., and K, Sanderson, The Rejuvenation of the Hannahs Block: An \\
\hline \multicolumn{2}{|c|}{$\begin{array}{l}\text { assessment of the impact of the what's new limited developments on Wellington city., } \\
\text { April 2004. } 6 \text {. Web. } 5 \text { Oct 2011. pii }\end{array}$} \\
\hline 18 & ibid \\
\hline 19 & Cassels, I., director of Whats New Co. Ltd. Personal Interview. 12 May \\
\hline \multicolumn{2}{|c|}{2011} \\
\hline 20 & Athfield Architects, Hannahs Factory. Wellington \\
\hline 21 & Stuart, N., "If the Shoe Fits". Architecture New Zealand November/ \\
\hline \multicolumn{2}{|c|}{ December 1989.36} \\
\hline 22 & ibid \\
\hline 23 & Arcus, M., and K, Sanderson, The Rejuvenation of the Hannahs Block: Ar \\
\hline
\end{tabular}




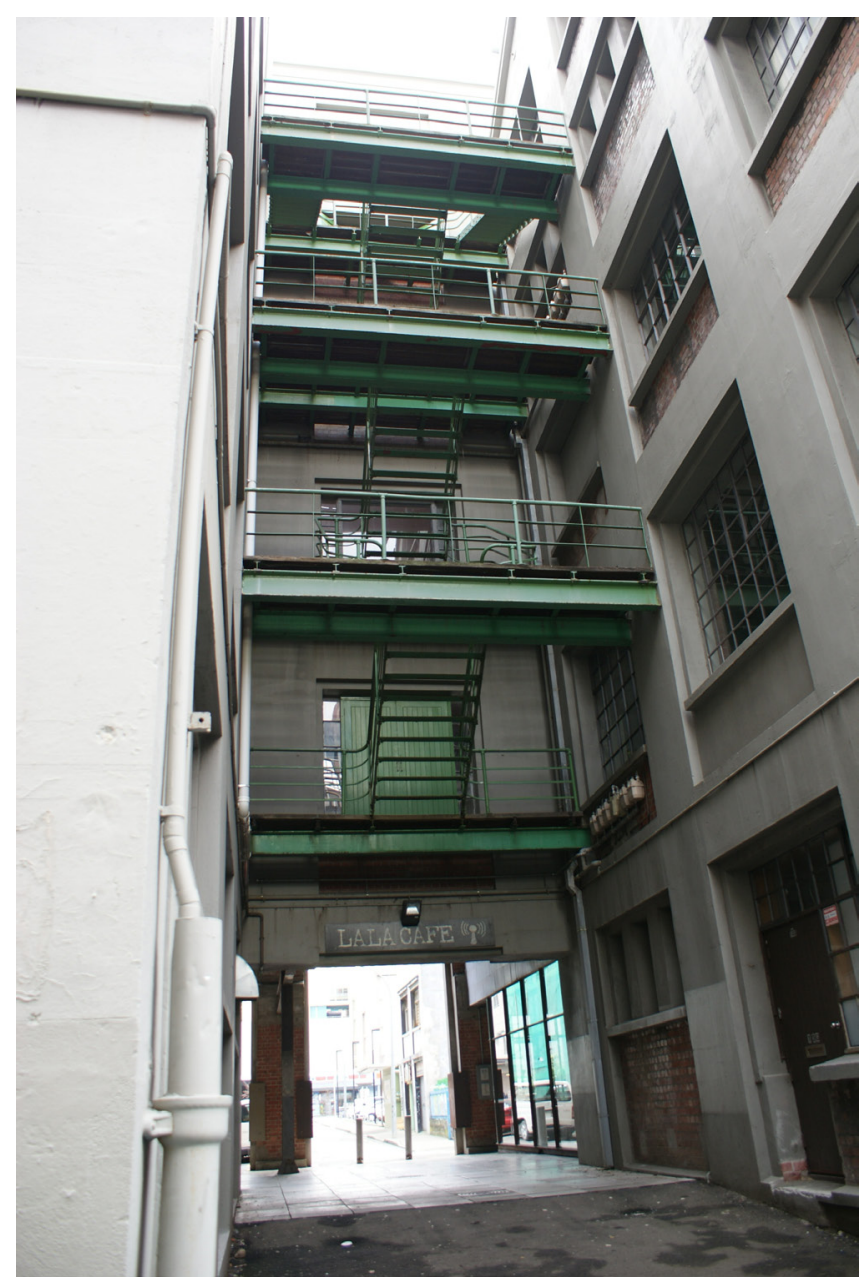

Fig 62. New access way from Ghuznee to Dixon was created by opening up the ground level.

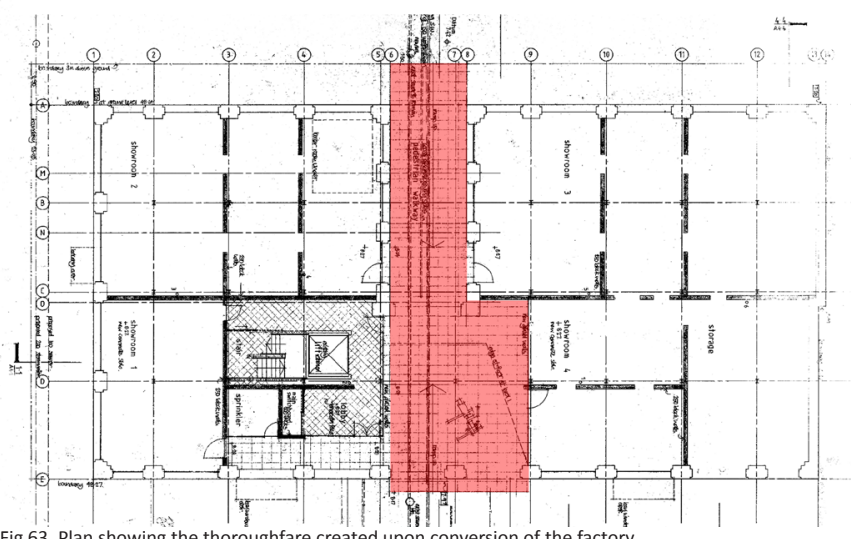

squatters could be found in both the factory and warehouse building.

Again this similar pattern can be compared to the

assessment of the impact of the what's new limited developments on Wellington city, April 2004,p6. Web. 5 Oct 2011 ii rejuvenation that occurred in the SoHo district after the loft dwelling artists began to renovate their own interiors, which led to a regeneration of the entire neighbourhood, as the once uninhabitable vacant spaces became popular outside the artistic sphere.

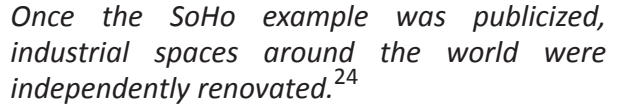

Athfield Architects work displays a conviction that strict adherence to typology and zoning is counterproductive and that richness and joy in our cities depends upon multiplicity of meaning and also on the subsequent ease with which buildings can be adapted to suit changing functions. ${ }^{25}$

The necessary mix was achieved by designating the ground area for commercial use and the opening up of the building centrally helped this by allowing pedestrian traffic through this area. The entry was however kept regulated with a curfew to help curb the night-time activity and separate the night scene from the residents after a certain hour in the evening. Archival material from Athfield Archives stated that,

The building has been cut open through its height to provide a large circulation area and, wherever possible, materials salvaged from the existing structure have been reused when reconstructing the apartments. A show apartment was built using prefabricated kitchen and bathroom shelves and joinery and this was used as a basis for sales. ${ }^{26}$

\section{Design of the Apartments and Car-Park}

Twenty-four apartments were designed to fill the four levels of the former shoe factory. Cassels negotiated putting a big hole through the building to provide a walkway through to Dixon Street. The area thus became accessible both from Leeds and Eva Streets allowing entry from opposite directions. Cassels described this as, "almost resettling the city."27

As previously mentioned, each apartment was advertised in the Hannah Prospectus as having its own secure internal car park and exclusive lockable storage. ${ }^{28}$ The provision of car parks never eventuated, and in fact the few car parks along the South face of the building belong to the Hannah Warehouse. Eventually the residents had to rent car parks elsewhere, as there was a deficit of available spaces for all

$24 \quad$ Kostelanez, R., SoHo-the rise and fall of an Artists Colony. New York 2003.139

25 Wright, R., "Appraisal." Architecture New Zealand November/December 1989,39

26 Athfield Architects, Hannahs Factory. Wellington. C 1998. CD

27 Wilton, C., "High-tech apartment life". City Voice. 30 January 1997.4 28 Gray,B., Crombie Lockwood \& O'Shea Ltd, Hannah prospectus, Athfield Architects, Athfield archives, 1996 
the residents. ${ }^{29}$ The only visible car parking spaces for the Hannah Factory are those directly surrounding it on the North and South sides.

The Hannah Prospectus advertised the apartments as one of Wellington's, most gruntiest and most unique apartment developments and a loft style city living. ${ }^{30}$ The prospectus also advertised some of the apartments as having the chance to be altered by purchasers, allowing their individual personality and needs to be reflected intheir space. ${ }^{31}$ The four smallest apartments within the Hannah Factory were all designed to be situated on the east and west ends of the building, spanning levels 1, 2, 3 and four. All are single storey one bedroom apartments and are a mirror duplicate of one another. Apartments twelve, sixteen and twenty four, being situated on the eastern side would have received the least amount of sun as they were positioned directly adjacent to 22 Leeds Street, a building of a similar height. Apartment 4 would have received slightly more light as there was an adequate amount of space between it and the adjacent Hannah warehouse. Other apartments on the eastern side had little light, being adjacent to a building with only a slight gap between them and it. The Hannah Factory apartments only spanned two levels, as opposed to the adjacent Hannah warehouse, which had single units spanning over three levels at most.

The Hannah Factory Apartments, in conjunction with the Hannah Block rejuvenation were Wellington's first example of converted factory and warehouse apartments. ${ }^{32}$ Aesthetically and conceptually the interior was designed with the intent to adhere to a loft look, through the use of retained industrial materials and by incorporating existing historic features. ${ }^{33}$ The intent was not to insert modern apartments within the space but to use the existing structure in the design of the new programme. The Hannah factory followed the general structural foundations of a warehouse and factory making it ideal for reuse. An open plan concrete and steel building like this was ideal for conversion.

According to the Wellington City Council, because the Hannah factory building is located in a area zoned central as opposed to Inner Residential, there was no requirement for parking in the central area (rule 13.1.1.7.1), only provision for a loading bay was required. ${ }^{34}$

\footnotetext{
29 Quade,V., personal interview, 27 Sep 2011

30 Gray,B., Crombie Lockwood \& O'Shea Ltd, Hannah prospectus, Athfield Architects, Athfield archives. 1996

$31 \quad$ ibid

32 Cassels, I., director of Whats New Co. Ltd. Personal Interview, 12 May

2011

33 Athfield Architects, Hannahs Factory. Wellington. C 1998. CD

34 Simmons, R, Planning Technician Local Area Planning Team

Development, Planning \& Compliance Wellington City Council, massage to the

author.16.11.11. email
}

Council lets the 'Market' lead the demand for parking and thereby through a space and cost detriment the citizens are persuaded to walk or use public transport. ${ }^{35}$

\section{Structural Changes and Redevelopment Work}

As Andrew Charleson states in his book, Seismic Design for Architects about diaphragms,

Existing diaphragms often require upgrading. Particularly in an unreinforced masonry building with wooden floors, it is not feasible to structurally improve existing low-strength diaphragms. In these cases new diaphragms are constructed above or below existing floors or ceilings. One method that involves casting a new reinforced concrete slab over the existing flooring, provided that the floor joists can support the extra weight, adds undesirable additional weight to the building. A lighter alternative diaphragm is fabricated from structural steel to form a braced diaphragm or horizontal truss. ${ }^{36}$

The Hannah Factory incorporated a large amount of brick in its construction which had to be reinforced upon the reuse into apartments. The building, being designed prior to 1935 , presented itself as uninsurable on the local New Zealand insurance market. ${ }^{37}$ The building was to be strengthened in accordance to the 1985 Red Book Standard, which at the time was the most recent Code. This would ultimately,

...raise the earthquake integrity of the building
ensuring that underwritten criteria would be
met enabling earthquake cover to be purchased
today and in the future and that it would
ultimately result in a substantial reduction
in the overall cost of insurance premiums to
ultimate property owners. ${ }^{38}$

The Hannah Factory prospectus also stated that the strengthening was significantly higher than stated in the code at the time and that this would ultimately result in potentially higher apartment resales, increased fire protection and improved acoustic performance. ${ }^{39}$

Fire protection to the inter tenancy timber framed walls, intra tenancy walls and remaining timber floors (not the concrete block walls) was in the form of fyreline attached to both sides on a resilient channel. This building has concrete overlay on two existing timber floor levels (intertenancy $35 \quad$ Wellington City Council. http://www.wellington.govt.nz/plans/district/ volume1/pdfs/v1chap12.pdf.(12.2.8.3) 10.11.2011

$36 \quad$ Charelson, A. Seismic Design for Architects. 198

37 Gray, B.,Crombie Lockwood \& O'Shea Ltd, Hannah prospectus, Athfield Architects Hannah Apartments prospectus, Athfield archives. 1996

38 ibid

39 Gray, B., Crombie Lockwood \& O'Shea Ltd, Hannah prospectus, Athfield Architects Hannah Apartments prospectus, Athfield archives. 1996 
Inter tenancy walls generally $190 \mathrm{~mm}$ thick masonry blocks reinforced and concrete filled, battened and lined or pastered.

Earthquake load resisting reinforced concrete block shear walls highlighted in colour

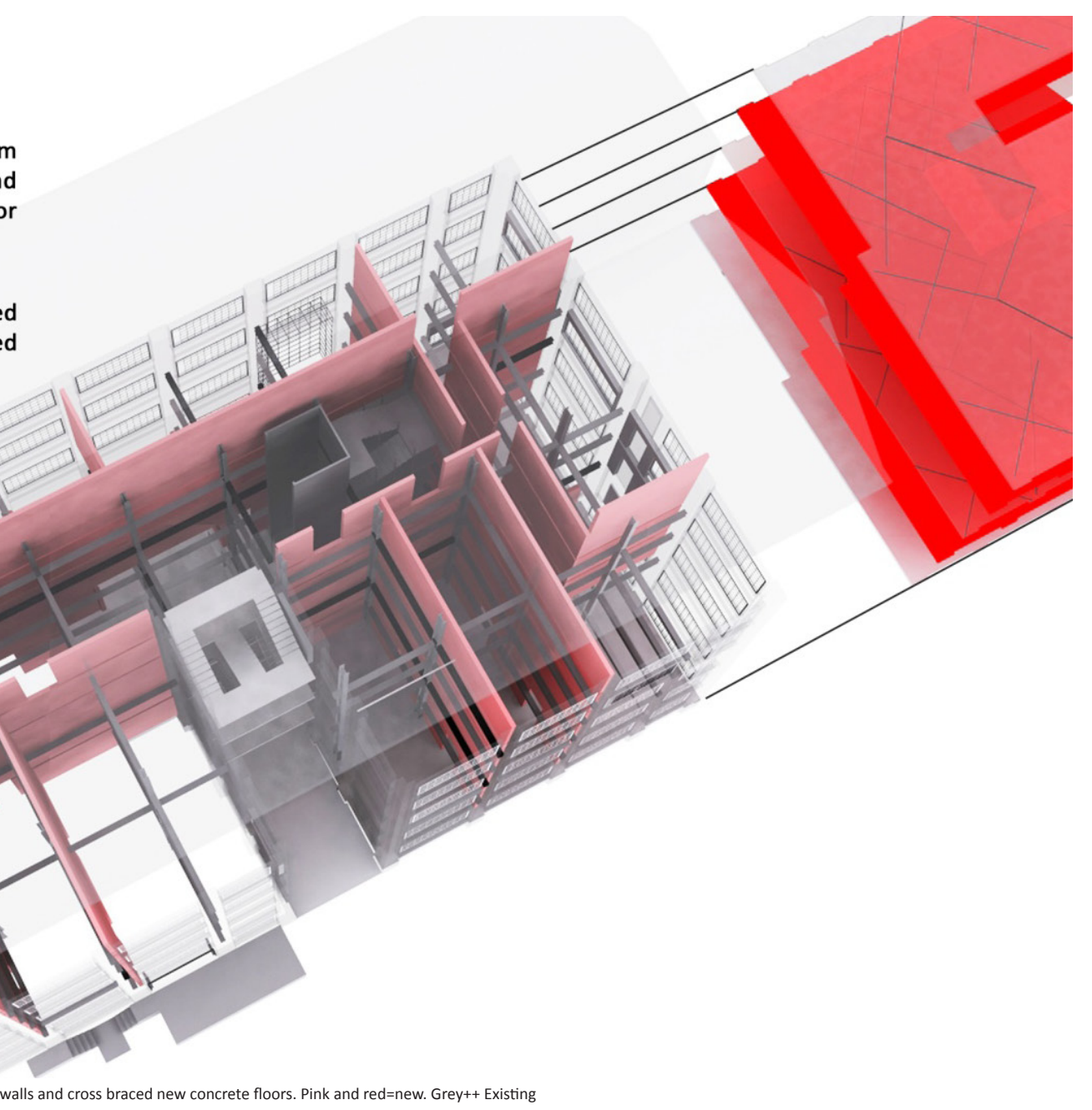

Fig 64. Digital Model Showing structural upgrade. Shear walls and cross braced new concrete floors. Pink and red=new. Grey++ Existing

levels), and the other timber floors were cross-braced with steel to their undersides. New walls were reinforced concrete block. A large concrete bond beam was inserted at each level and the steel floor beams were well anchored to this. New reinforced concrete block shear walls, constructed between various apartments, resist the earthquake loads. They were selected based on strength and stiffness, which was to limit deformation of the building, as well as for fire protection and sound absorption.

\section{Design Approach}

The apartments were designed with the intent of retaining as many of the original features as possible, and keeping the aesthetic within a warehouse/loft style apartment theme. The existing timber floors were retained and made good, sanded and waxed or clear coated for protection. Existing brick walls and concrete perimeter walls were plaster patched and painted with cement based paint to the same colour as existing. It was important to Athfield to leave the existing brick unpainted, "he insisted the integrity of the buildings should be kept-we can clean but not paint the exterior." ${ }^{40}$

Several features within the building were either reused in situ, retained or reused in other areas. As with the additional new material and strengthening work, these materials were left raw and exposed. The existing lift was also retained but refurbished with new tiling, and servicing at all levels. The old manual lift doors were to be replaced with new automatic ones. The lift car and shaft that was centrally located was removed.

The existing timber stairwell was repaired and made good. A new stairwell located next to the lift was of similar design and construction to the existing stairwell. The elements that were reused from the original design kept the industrial theme that related back to the programme and rich past of the building. A certain industrial character remained within the interior after the conversion into residential apartments by keeping such elements and working with the same aesthetic.

\footnotetext{
$40 \quad$ Shaw, B., "Building saved by boom”. Evening Post. 4 June 1996.13
} 


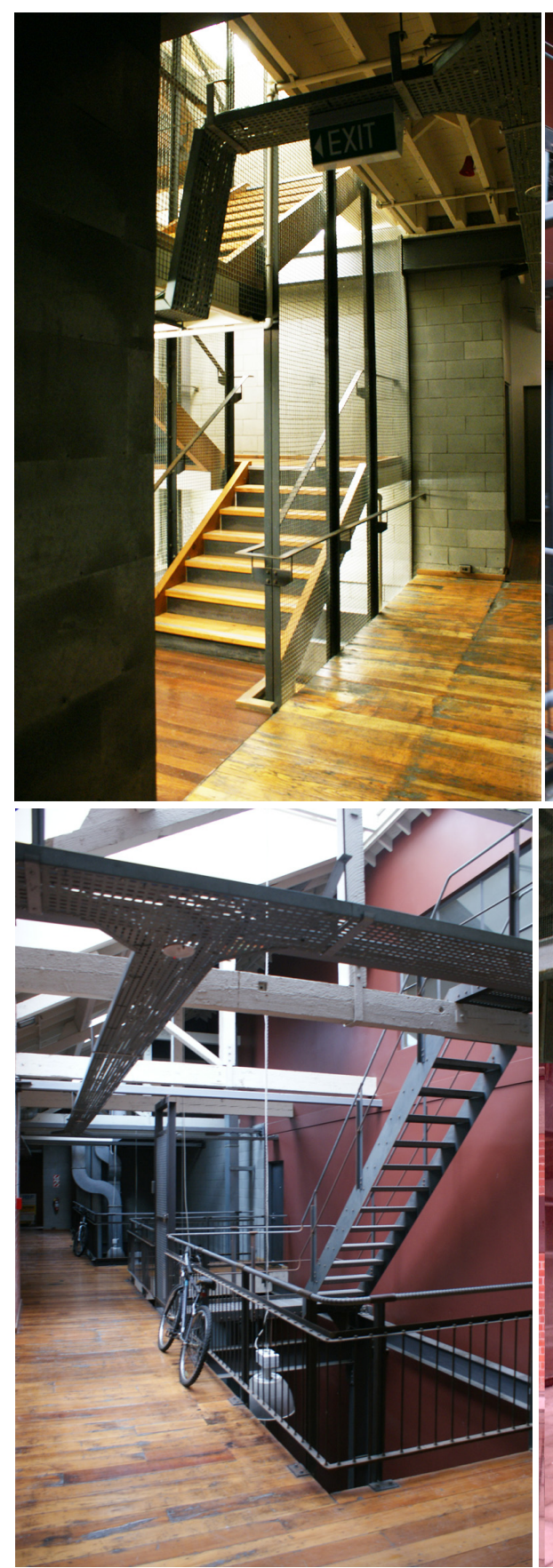

Fig 65. Industrial aesthetic visible throughout the building. Note, old elevator reused

All common areas continued this raw industrial theme, paramount in the overall approach Athfield Architects envisioned. The prospectus also stated that, the apartments would be,

subject to adjustments for each apartment's individual requirements pursuant to the Athfield plans. Where possible purchasers may alter features of apartment design to reflect their own ideas and requirements. ${ }^{41}$
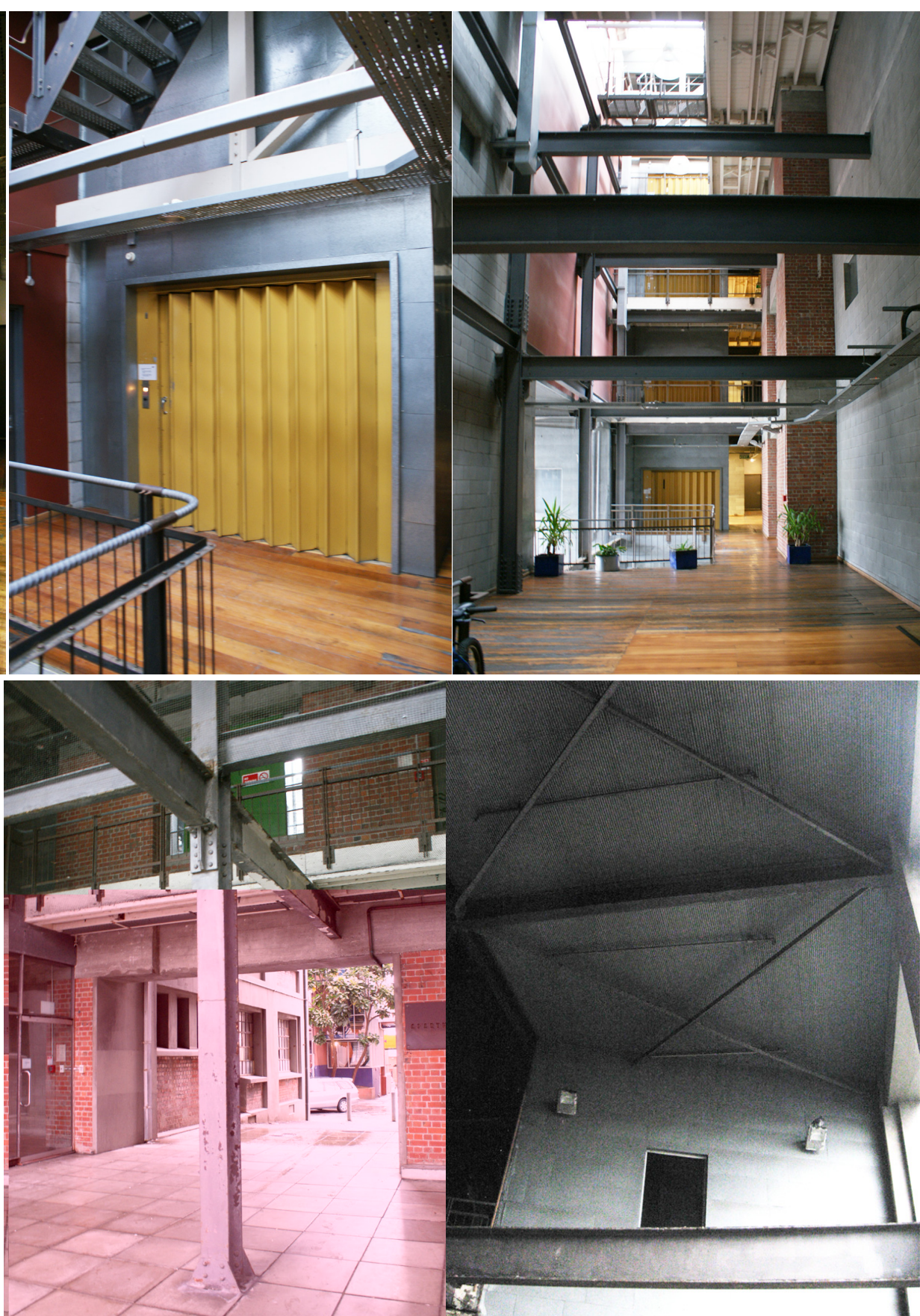

This would allow for a personalisation of space and each apartment to suit the owners' desires for their home. This is different from the majority of apartments around the city, including the Odlin's renovated apartments.

The common areas, including lobbies, stairs and lifts, were to remain within a consistent theme and provide a subdued entry to the apartments.

One of the biggest changes, as previously mentioned, was the new open thoroughfare to Dixon Street at ground level, 
leading directly from Leeds Street. The grand double entrance that was inserted was 8 metres high. Part of the existing first floor level had to be removed to accommodate this new open space. This added a sense of grandeur and focal central point to the building, as prior to this change the entrance was minimal and functional.

Because the theme of a warehouse and loft space was incorporated in the design, the bathrooms and bedrooms had roller shutter doors that could be closed off when required, operated by electric motors. The shutters sat inside a clear powder coated steel frame.

The double height design feature was employed throughout the building. The hallway floors on levels two and four were removed to create a double height hallway area, whereas on the other levels hallway areas were repaired, sanded and waxed or clear coated for protection. Double height spaces were also achieved with some of the apartments having parts of their upper floors removed within the unit, in turn allowing for maximum light and openness and creating a distinctive and exciting living environment. Purchasers were to have the option of whether they wanted to retain this floor area for extra bedrooms and floor space or have the area removed as described above to create the double height space.

\section{$\underline{\text { Structural Upgrade }}$}

The existing brick infill parameter walls and floors $13.7 \mathrm{~m}$ floor to ceiling span on level one), were supported internally on steel beams and columns. As part of the strengthening required for the building, a large concrete bond beam was inserted at each floor level and the steel floor beams were well anchored into this.

The Hannah factory was strengthened in accordance with the New Zealand National Society for Earthquake Engineering 1985 document, "Earthquake Risk BuildingsRecommendations and Guidelines for classifying, Interim Security and Strengthening."

\begin{abstract}
The earthquake loads on the building will be resisted by a series of reinforced concrete block shear walls which will be constructed within the building between various apartments. These have been selected because of their strength and because their large stiffness will limit deformation of the building. In addition they provide sound absorption and fire protection between the apartments. ${ }^{42}$
\end{abstract}

$250 \mathrm{~mm}$ thick unpainted fairfaced concrete block walls were incorporated (Fig 66 and 67). The structure was strengthened through its total height with the introduction of reinforced

\footnotetext{
42 Gray, B., Crombie Lockwood \& O'Shea Ltd, Hannah prospectus, Athfield Architects Hannah Apartments prospectus, Athfield archives. 1996
}

concrete block dividing walls.

As of August 2011, the Hannah Factory is in negotiations to have more structural work done to comply with current standards. The engineers involved with this building will no longer be Connell Wagner. ${ }^{43}$

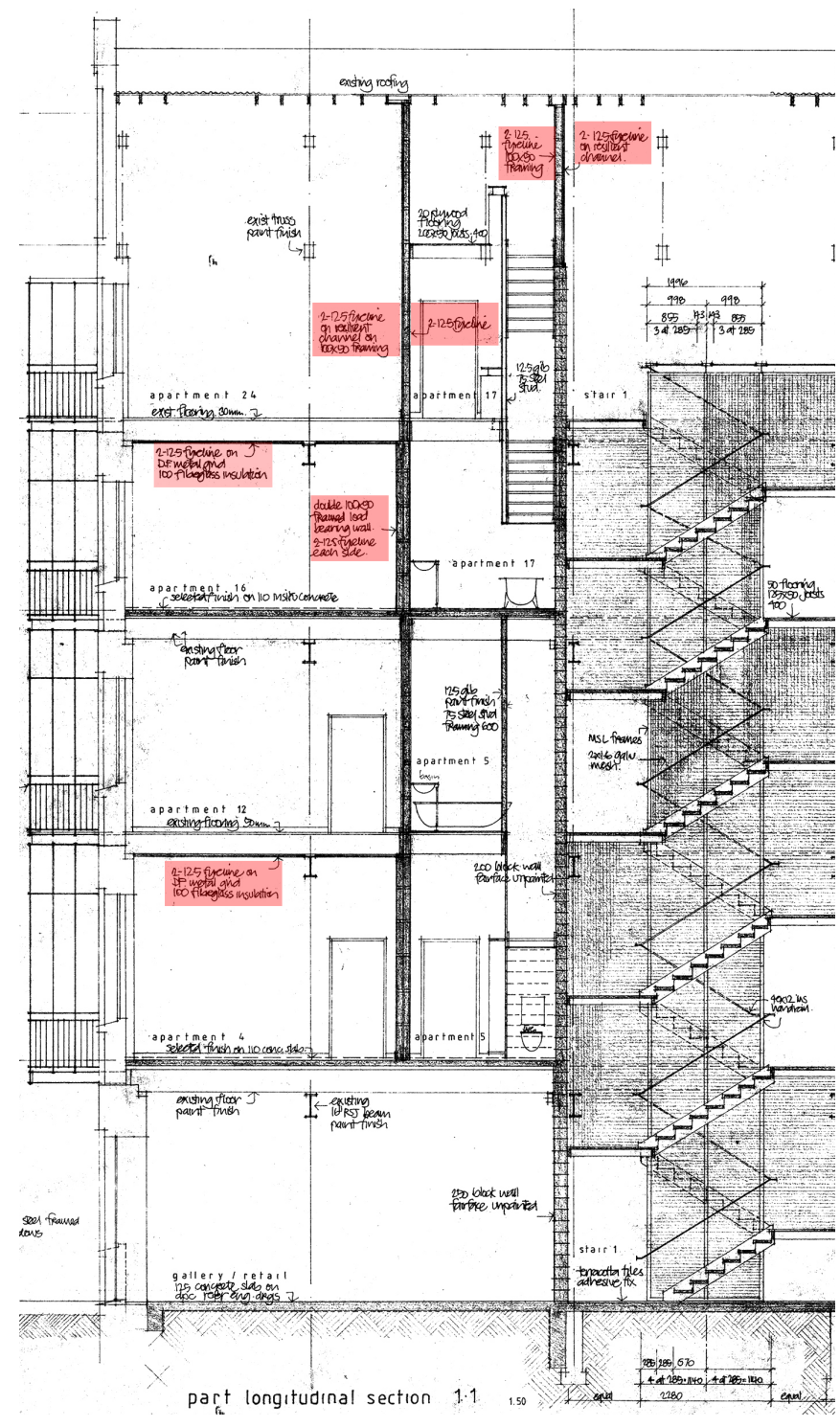

Fig $65 \mathrm{~b}$.This section illustrates the application of the fyreline to the underside of some of the floors and the walls.

\section{$\underline{\text { Floors }}$}

The Hannah factory prospectus stated that the floors would either be strengthened and retained or have a new layer of insitu concrete poured over the top of some levels,

The existing timber floors of the building will

$43 \quad$ Gledhill, S Aurecon - Building Structures Service Leader. Interview.29 Aug 2011 
Windows: existing steel windows refurbished and painted. Damaged glass replaced with float glass.
The exterior concrete walls were faced with brick laid in English bond.

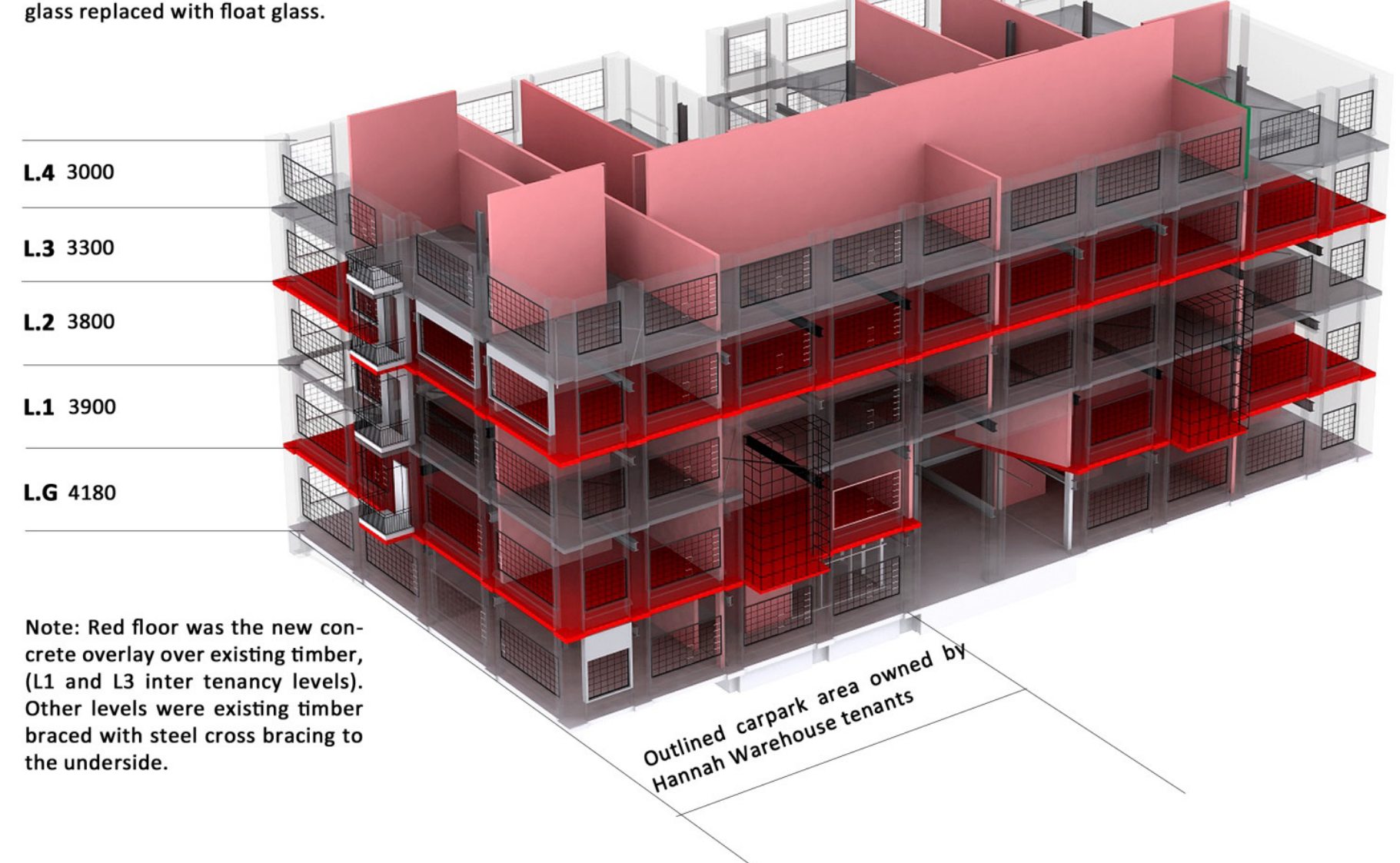

Fig 66. Digital render showing new concrete floors in dark red and the shear walls. Pink and red shows the modifications and new elements.

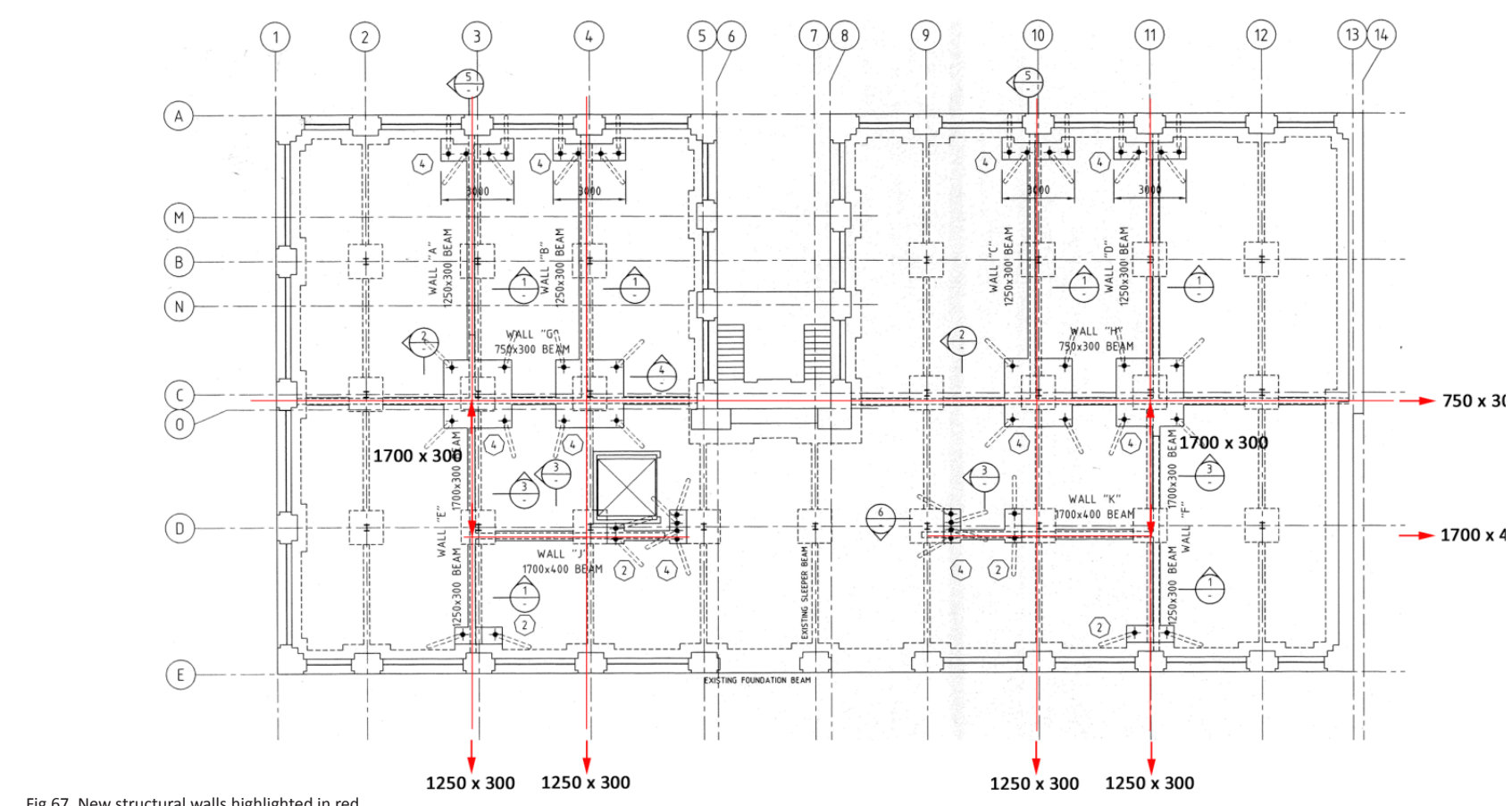


A large concrete bond beam is at each floor level and the steel floor beams are well anchored into this.

Steel cross bracing visible

L.4

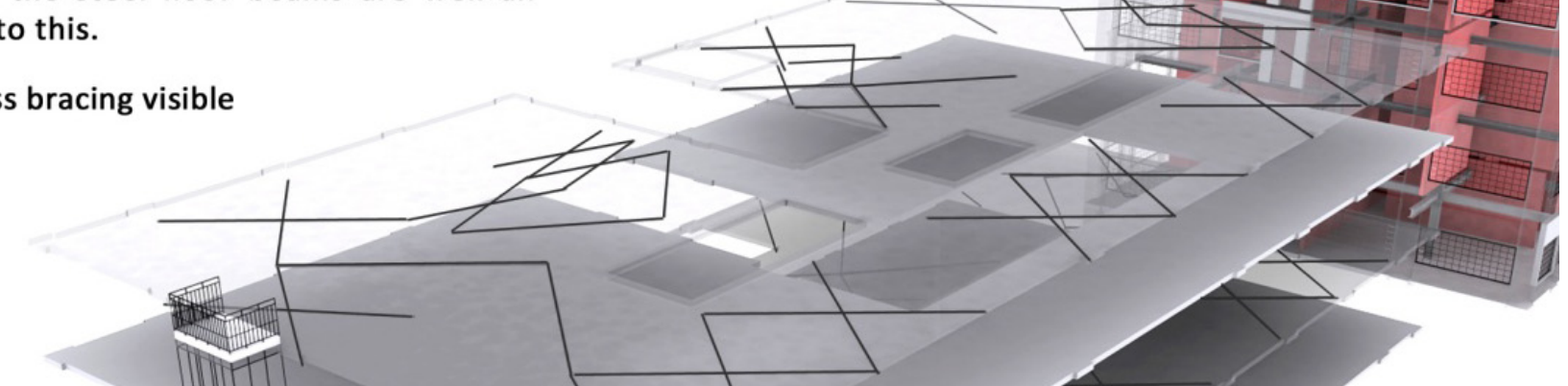

L.3

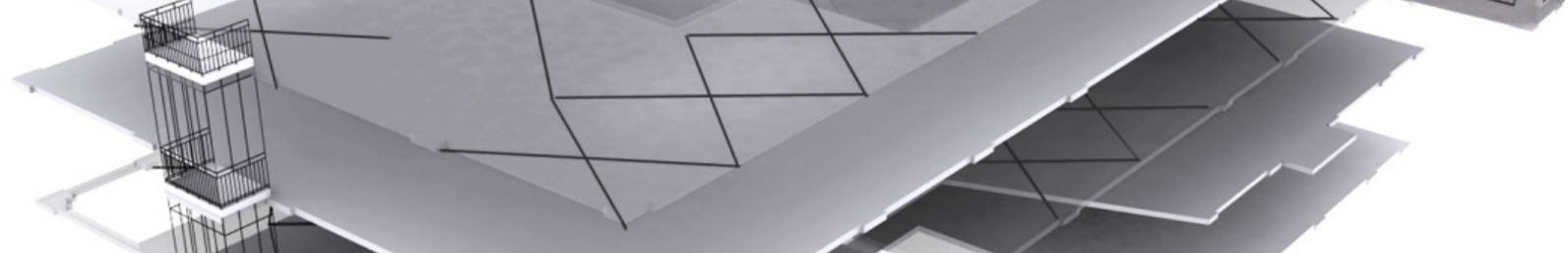

L.1

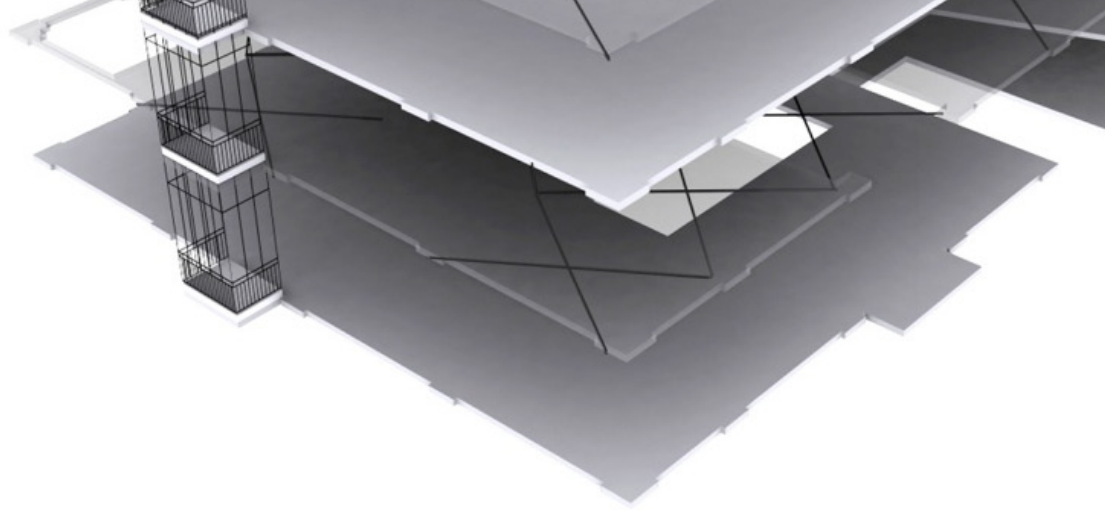

Fig 68. digital render showing new insertion of steel cross bracing to the underside of floors as well as bond beams

be strengthened either by steel cross bracing beneath the floors or by a concrete overlay on top of the floors, to ensure that

the loads on the brick walls are transferred to the new shear walls. The concrete overlay will be used between apartments as it will also provide sound absorption and fire protection. ${ }^{44}$

The earthquake strengthening (listed below) that was required to make the building comply with code and be habitable was made into a feature, especially through the use of their exposed structural steel. ${ }^{45}$

- Gallery/retail level- 125 concrete slab

- Level 1- 110 concrete slab floor

- Level 2- 2-125 fyreline on DF (directly fixed) metal and fibreglass insulation

- Level 3-110 insitu concrete slab floor

- Level 4-2-125 fyreline on DF metal and fibreglass insulation

- $\quad$ Structure often cleaned but left unpainted e.g floors $^{46}$

(Refer to Drawing 65b for reference)

$44 \quad$ Gray,B., Crombie Lockwood \& O'Shea Ltd, Hannah prospectus, Athfield Architects Hannah Apartments prospectus, Athfield archives. 1996

45 Brown, K., "When the Shoes fits". The Dominion Post.October 12, 2002

F16

$46 \quad$ Athfield Architects, Hannahs Factory. Wellington. C 1998. CD
The new concrete slab at the First and Third level covered the existing timber floor, an unusual move on Athfield's part, as one of the key themes for this conversion was to preserve as much of the original building fabric as possible. This however may have been to make it fire proof proof. Carpet was also laid over top of the new concrete. This was described in several elements throughout the conversion where material was left unaltered, such as the exposed brick and ducting in the ceilings.

\section{$\underline{\text { Fire Protection }}$}

As with the Hannah Warehouse the building was divided into fire cells with the insertion of partition walls to section off apartments. Intertenancy walls, duct walls and corridor walls were specified to be $190 \mathrm{~mm}$ masonry blocks reinforced and concrete filled, battened and lined or plastered. Other intertenancy and inratenancy timber framed walls were to be soundproofed, insulated and fire rated to Winstones GBTLA 60a specification, giving FRR 60/60/60 and sound ratings of STC 55 and IIC 55.

Typical partition walls were to have $75 \mathrm{~mm}$ fibre glass insulation. The floors were to have fibre glass within the fyreline on the metal grid at ceiling level to protect the timber floor structure.

An automatic fire alarm system was to be provided in 
accordance with NZBC. A type 4 system was used generally consisting of smoke detectors in individual units and common areas, alarm sounders at each bedhead, living and common areas, manual alarm call points in the exit paths from the building, and fire service $24 \mathrm{hr}$ per day monitoring of the building. Fire hose reels were also fitted in common areas.

\section{Windows}

The existing steel windows were refurbished and painted. All existing damaged or unsightly glass was replaced with float glass, to match existing. New windows, balcony windows and doors were powder coated aluminium framed windows with sashes, and glazed bifolding doors. New steel framed windows with plaster sills were inserted at ground level. A new steel framed balcony system was installed at the west end with new double height steel framed bay windows to the south side.

\section{$\underline{\text { Residents and Demographic }}$}

The residents that first occupied the Hannah Factory included artists, designers and those involved in the creative industry and the spaces were marketed to include those who worked and lived at home. ${ }^{47}$ This shows a similar trend to the pioneering Soho lofts in New York in the sense that they were also occupied by artistic types. In Wellington, however, these places sprang not out of necessity, lack of space and an abundance of such spaces but due to a developer seeing an opportunity in the market.

\section{Apartment 2}

\begin{abstract}
Abandoned shoes, machinery and other relics are reminders that this building in Leeds Street once played a vital part in Hannah's footwear empire. $^{48}$
\end{abstract}

Traces of the building's former nature prior to reuse as an apartment block are some of the most interesting aspects that allow for warehouse apartment living to be unique.

This two bedroom apartment is situated on level one and spanned two levels. The residents are a young student couple. The lower level is open plan, incorporating the kitchen into the living and dining area. The total area of the lower level is $50 \mathrm{sq} \mathrm{m}$ and the top level $36 \mathrm{sq} \mathrm{m}$. Including the open space area, the total area of this apartment comes to $99 \mathrm{sq} \mathrm{m}$. A small toilet is also placed below the staircase.

The kitchen and joinery follow an industrial feel with stainless steel bench tops and highly polished surfaces that

\footnotetext{
$47 \quad$ "Chic City pads for the well-heeled". Evening Post. August 13, 1997
} Alexander Turnbull Library

48 Shaw, B., "Building saved by boom." Evening Post, 4 June 1996. 13 have the appearance of being high tech and modern. The benches are powder coated steel frames on aluminium feet. The feeling of impermanence translates through their free standing appearance, yet an industrial feeling is also present, theming with the original programme within the former factory building. The Hannah Factory's industrial aesthetic carries through into the kitchen, with stainless steel bench tops and metallic details. The Athfield Architects' specification stated that the kitchen joinery was, "purpose designed free standing units housing the various fittings, cupboards etc. In clear powder coated steel frames on cast aluminium feet" and the kitchen units had "powder
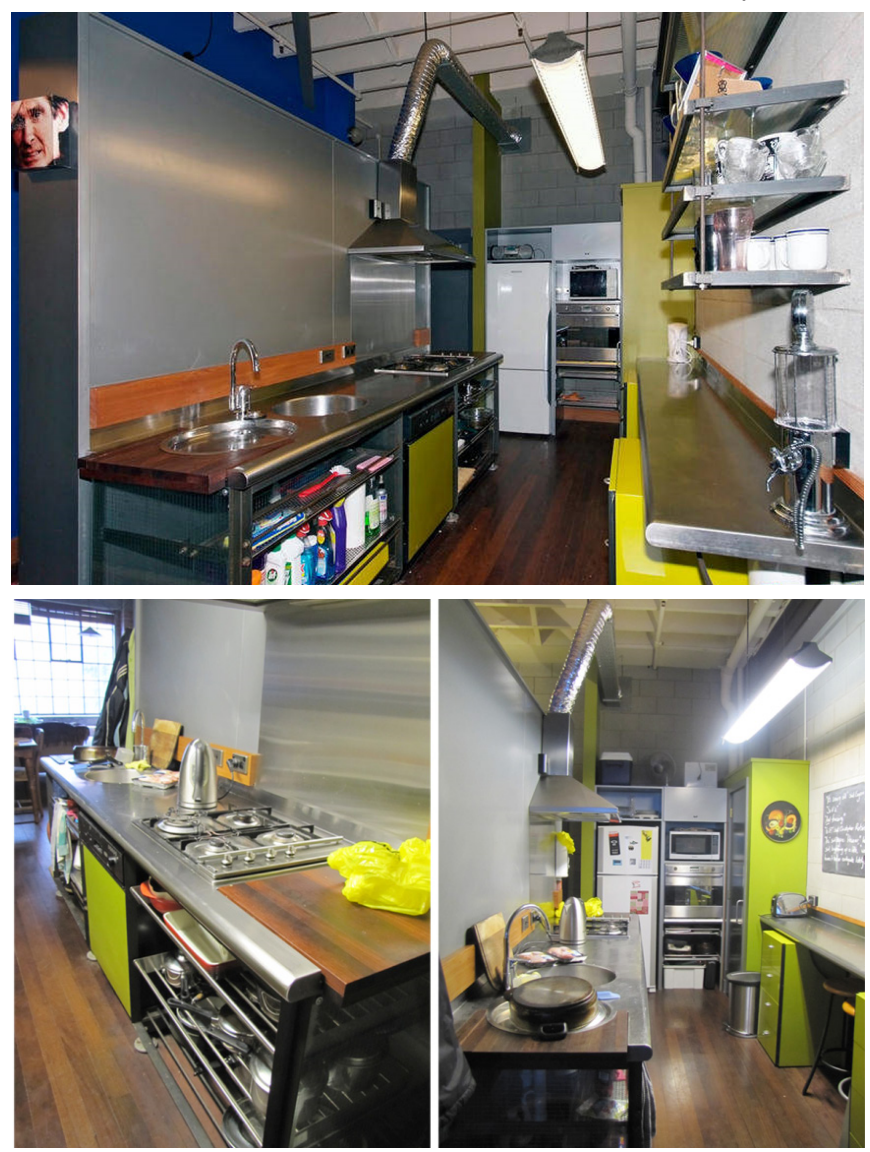

Fig 69. Industrial elements were used in the kitchen joinery and fittings. Piping and wiring was left exposed.

coated steel frames, $18 \mathrm{~mm}$ spray lacquer doors with three way adjustable spring hinges...". The rest of the fittings were also specified to be stainless steel.

The kitchen cupboards have doors of steel mesh, and steel shelves are suspended on poles. Everything seems light transitory, insubstantial, within the solid brick of the walls. ${ }^{49}$

A clear distinction is therefore made with the modern kitchen and its free standing units as opposed to the bold 49 Wilton, C., "High-tech apartment life". City Voice. 30 January 19974 

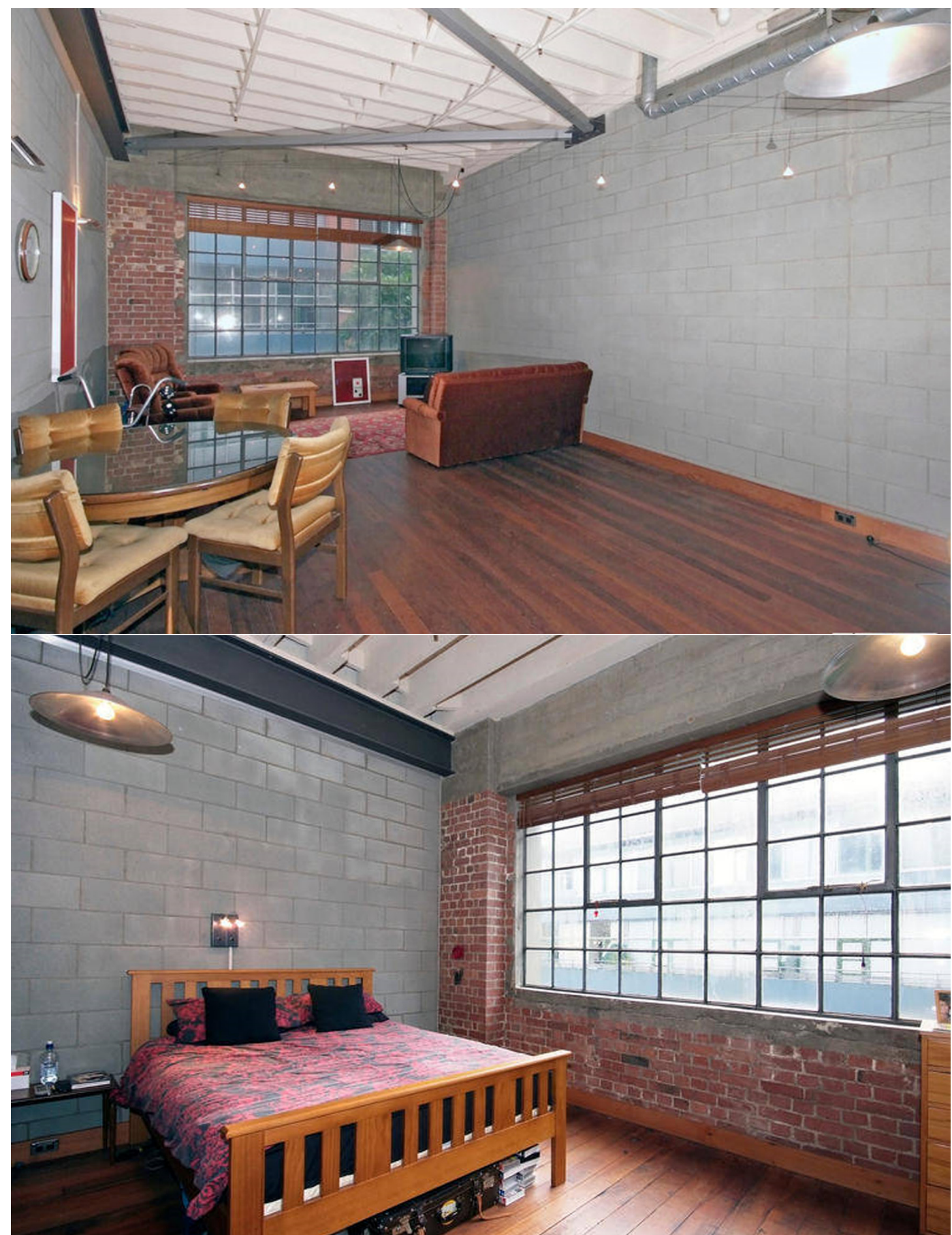

Fig 70. Apartment 2 Interior

and heavy historic brick and surrounding structure that has a sense of permanence, contrasting against the new and changeable additions. A feature in Architecture New Zealand described the Athfield intervention in the former factory building as "industrial chic" and having created a "highly charged urbanity" through the use of the generous ceiling heights, bare floorboards, exposed pipes and industrially

crafted joinery items. $^{50}$

The living room is open plan and faces north, overlooking the car park area below. The penetration of light is somewhat minimal. The tenant stated the sound of the pipes working was the biggest noise interference within the unit as these were left exposed and were interconnected throughout the

$50 \quad$ "NZIA Resene Branch Awards. Hannah Factory Apartments. Wellington. Athfield Architects: Ian Athfield."Architecture New Zealan., Jan/Feb 2000. 19 


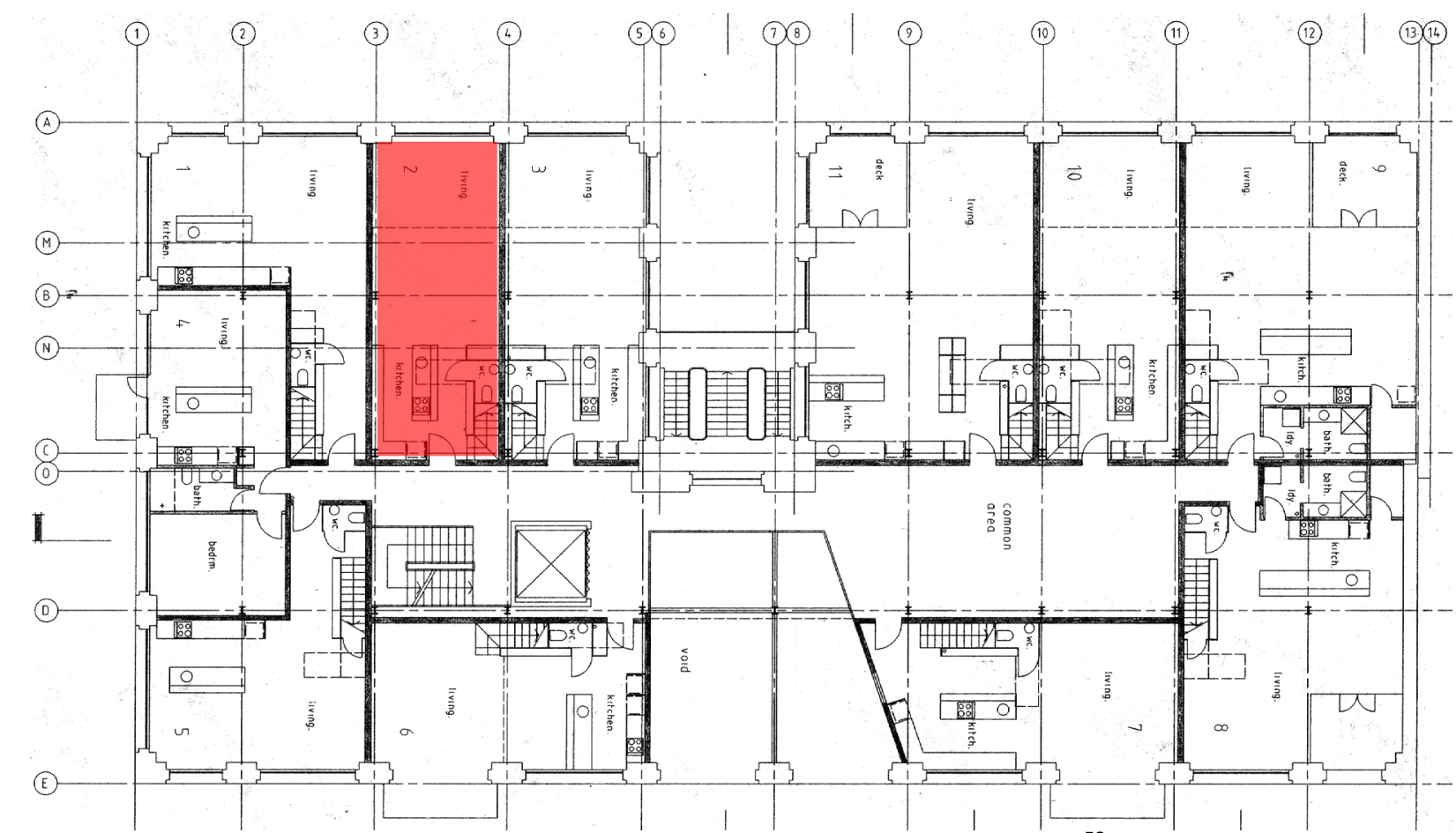

Fig 71. Smaller apartment 2 highlighted. The apartment spanned two levels

fluffy carpets there ".52 The present tenant of Apartment 2 stated they did not alter any of the interior colours within building. This sound is greater than sound transmission from adjacent units and those situated above. The specification stated that,

Precise detail and construction design are required to retain the building's original features, in conjunction with achieving high structural and intertenancy acoustic levels. ${ }^{51}$

The specification required installation of a gas bayonet and power outlet to allow residents to put in their own heating if required, although the tenant of apartment two stated they had not yet needed to install gas heating, as the place was warm enough.

The specification stated the internal walls (within the unit) were timber or metal frame, gib lined, plastered and painted. Insulation was provided in the roof and ceiling where necessary and the exposed timber was left uncovered, but painted with a low sheen coloured acrylic paint. This applied to all areas throughout the building apart from the bathrooms. In the specification the skirting boards were either steel plates or timber similar to that of the floor boards, bolted to but spaced off from the wall. Athfield decided that as well as keeping the existing bricks unpainted the floors were to remain bare and uncarpeted.

Athfield himself stated that there was to be "no plaster or the unit. The bright orange in the bathroom and green in the kitchen was, therefore, presumably the original colour scheme used by Athfield Architects.

The strengthening work therefore, was also left exposed, and visible in the cross bracing in the ceiling and steel horizontal beams running at the tops of the walls. A sense of spaciousness was established, especially in the double height spaces where the ceilings were cut away, to give a two storey stud and two storey's worth of windows, evoking a spaciousness that belies the room's size. ${ }^{53}$

The staircase leading to the top level within the unit is narrow $(750 \mathrm{~mm})$ wide and made from particle board with metal nosings at each riser edge. Upstairs the two bedrooms are placed opposite each other with a bathroom separating them. The bathroom follows a similar industrial style, in terms of material use, employing exposed steel ducting and piping, tiles for the floor, glass and steel for the cabinets and sinks and painted a bright orange colour. An interesting touch was the freestanding bath tub which was cast iron with ebmellished ornate feet. The bathtub was specified in the buyers prospectus and came with the apartment upon purchase.

The bedroom facing the corridor has no natural light as it looks directly into the common hallway area, and is therefore very dark. The bedroom facing the north is well lit and is the $52 \quad$ Wilton, C., "High-tech apartment life". City Voice. 30 January 1997. 4 53 ibid 

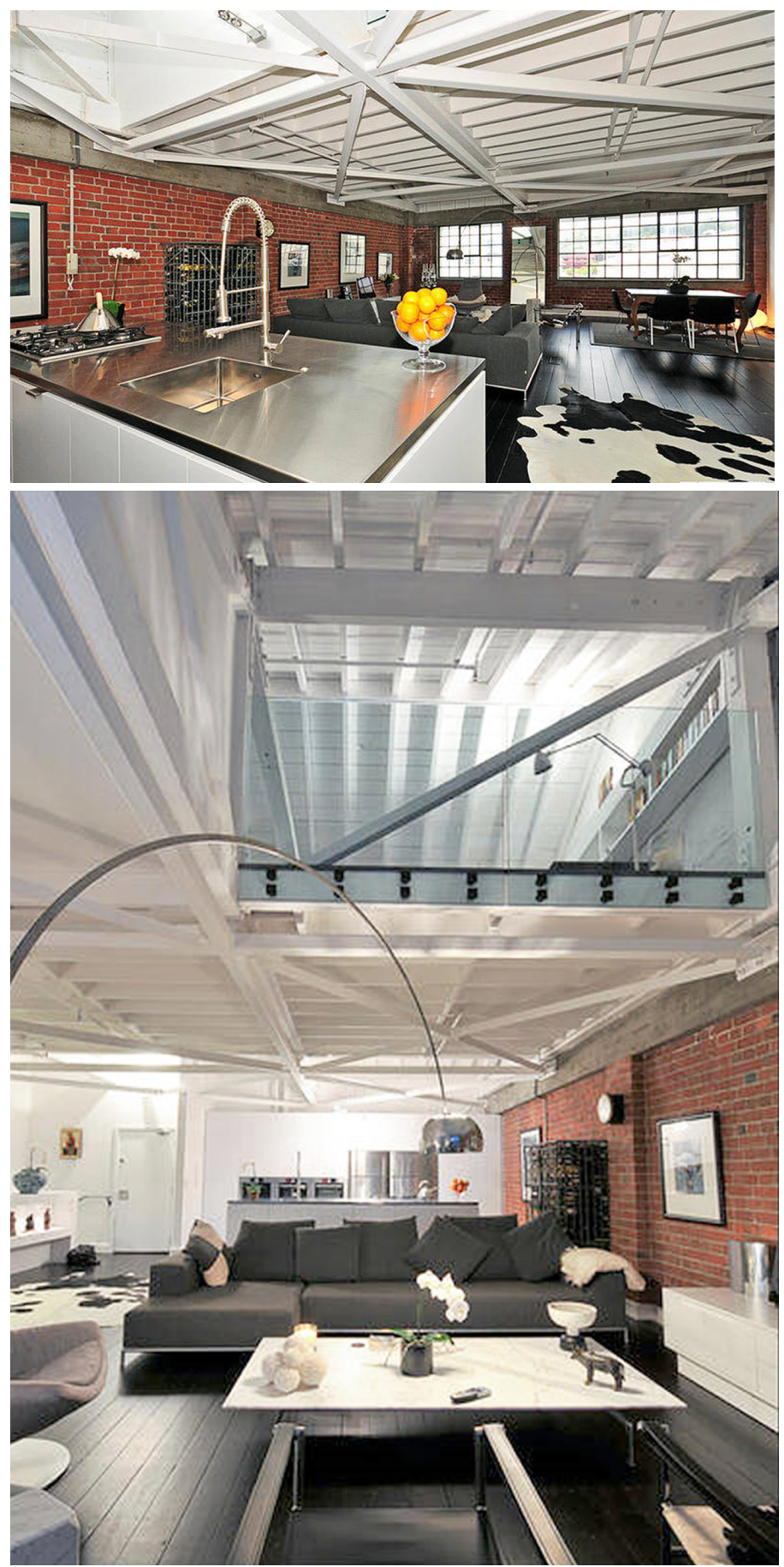

Fig 72. Above, one of the largest apartments in the factory. Drastic changes appear to have been made to the original scheme and aesthetic of the earlier apartments and specification by Athfield Architects. Including painting the exposed timber in the ceiling, white washing of the brick, staining the existing timber floor a darker hue, insertion of a glass balcony on the mezzanine level and new kitchen fittings.

lightest room in the apartment. This area feels the warmest in the apartment as the light hitting the brick made it seem as though it radiated heat and warmth. The floor on both levels within the unit is exposed existing timber.

Fig 72 shows one of the larger apartments within the Hannah

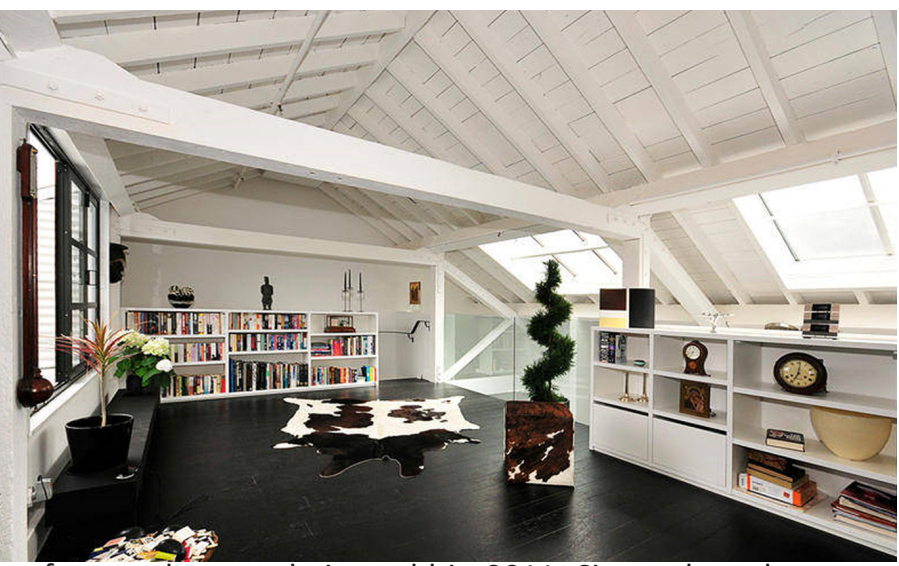

factory that was being sold in 2011. Situated on the upper level this spacious three bedroom two bathroom apartment also had access to a terraced balcony. The apartment had visibly been modernised, and floors appear to be stained a darker colour. ${ }^{54}$ The apartment was priced at over $\$ 1,375,000$ with a body corporate fee of $\$ 541$ per month. ${ }^{55}$ It was described as being restored to a very high standard, including high quality fixtures and fittings. The visible brick walls and strengthening elements were left untouched, however the steel cross beams have been painted, to continue the light spacious theme. A great deal of adjustment on the part of the previous homeowner had gone into this apartment since its initial conversion by the architects.

\section{Warehouse and factory living}

When warehouse living was virtually unheard of and the artist pioneers were illegally squatting in these buildings, they had the freedom to convert the space into the home they wanted. This was the appeal of factory and warehouse living as a building that was formerly used for industrial work now had the chance to be converted into a completely different use. This was seen as an act of individual expression, and the non artist soon caught on to this phenomenon. With the warehouse developments that have occurred in Wellington city, the ones sold as shells with the greatest amount of freedom to be done up by the individual relate to this notion of creating individualistic space. Warehouse apartments form a blank canvas upon which the inhabitants can personalize their house into a home that reflects themselves. Therefore, the best conversion examples appear to be the ones that have allowed the owner to be original and creative.
Remax real Estate Hannah factory 14 Leeds Street web. 2 Aug 2011. ibid 


\section{4:}

\section{History of Hannah Warehouse}
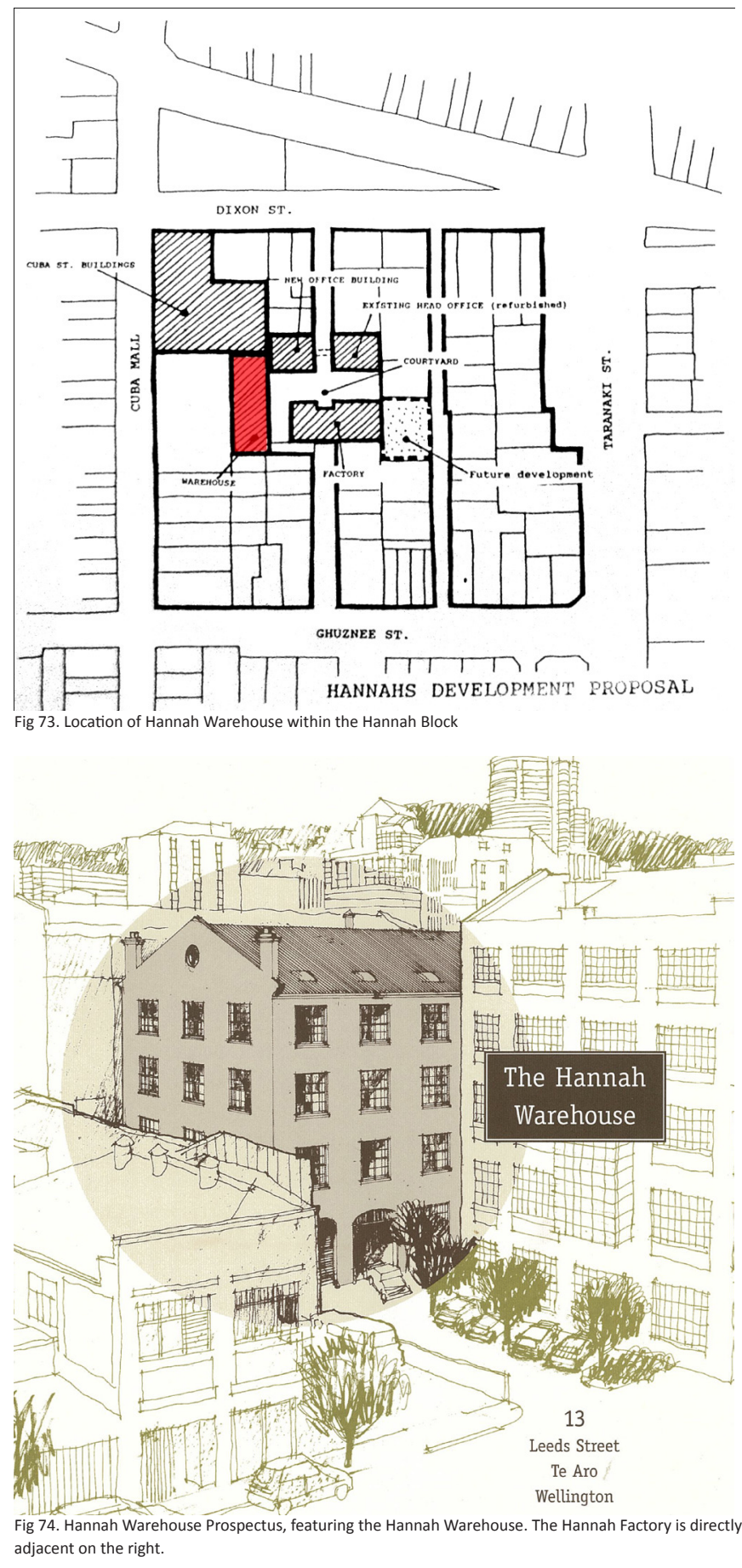

The Hannah Warehouse, also within the Hannahs Block, was bought and converted by private owners as opposed to developers. The Hannah Warehouse at 13, Leeds Street, Te Aro was built in 1909 by Sander Bros, to house the footwear firm's operations when its Lambton Square premises became too small. The architects were Penty and Blake. The neighbouring Hannah factory was subsequently built in 1923. The warehouse was owned by Robert Hannah, like the later Hannah Factory. The Warehouse, originally called the Hannah Boot Factory remained in continuous use by Hannahs for 85 years. However it was not called the Hannah Boot Factory for the full 85 years. $^{1}$

The building was used as a warehouse until 1987, when it became mostly a dispatch warehouse until the mid 1990s when the company stopped producing their own shoes. ${ }^{2}$

Like many of Wellington's well known establishments, the footwear company of Hannahs had its beginnings during the early years of settlement.
By the First World War, many of Te Aro's main thoroughfares and small connecting streets were well populated with shops and warehouses. Manufacturing, one of the major employers of the 1900s, also found the Te Aro flat a convenient location and such concerns as Hannah's boot factory tended to displace the domestic nature of the area. ${ }^{3}$

Being in the inner city and on flat land the Hannah Warehouse would have been accessible both to workers and the public, therefore its location in the Leeds Street cul de sac was important.

\section{Existing Construction and Materials}

The building structure was built to last a long time. It was made from cast iron columns, steel beams and rolled steel joists, and immense Oregon timber trusses spanning 16 metres which were wide enough to walk through. Other materials included brick exterior walls covered in plaster with a concrete band running across, corrugated iron for the roofing, Matai timber floors and timber window frames. ${ }^{4}$

The ground floor was originally used as the machinery floor and housed an engine room. There was also a hoist that spanned all three floors and a cart dock at ground level.

Prior to its conversion into apartments in 1997 the Hannah Warehouse was an industrial building in one of the last industrial enclaves in central Wellington.

$\begin{array}{ll}1 & \text { Hannah Warehouse Prospectus, 1999. Source Victoria Quade } \\ 2 & \text { Victoria Quade, personal interview. } 27 \text { Sept } 2011 \\ 3 & \text { Hodgson, T. Colonial Capital Wellington 1865-1910, } 39 \\ 4 & \text { Penty and Blake. } 13 \text { Leeds Street, factory. } 21 \text { Jan 1908. Building Permit/ } \\ \text { Consent. 00053_143_7933. Wellington City Council Archives. Wellington. } 1 \text { Sep 2011. }\end{array}$ CD 
$\underline{\text { Reuse }}$

In 1996, architects John Gray and Helen Tippett along with two other families bought the Hannah Warehouse from the Hannah family for a total of just under one million dollars. It had been unoccupied for 4-5 years prior to this when it stopped functioning as a factory. The 96 year old Hannah Warehouse had been declared unsafe and was vacant ${ }^{5}$ when Gray and Tippett bought the property in order to rejuvenate and convert the derelict site. John Gray did the conceptual design work for most of the interior, and had a part in the project management and Gus Watt was engaged to produce the architectural drawings and specifications. Helen Tippett managed the project. Don Thomson Engineers undertook the structural engineering design and Norman Disney \& Young were the building's services engineers. ${ }^{6}$

The Hannah Warehouse prospectus that was put together described the vision and the team behind the development.

\begin{abstract}
Our vision is to be part of the move to the inner city, so a group of friends and professional colleagues went in search of the right building. We discovered 13 Leeds Street, The Hannah Warehouse. The perfect place for inner city living. ${ }^{7}$
\end{abstract}

garages and a pizzeria. ${ }^{8}$ The spaces were advertised as having the flexibility to be sublet for smaller studios or subdivided as apartments and workspace. The five studios were also advertised as having the opportunity to be easily converted into apartments. ${ }^{9}$

John Gray and his three other friends and colleagues bought the warehouse for nearly $\$ 1,000,000$. The sum cost of the renovation project was approximately $\$ 6,000,000 .{ }^{10}$ The strengthening work alone cost $\$ 800,000$ to do, so the project went from being an "inexpensive one to an expensive one". ${ }^{11}$ In 1997, advertised prices of the new apartments ranged from $\$ 157,500$ to $\$ 295,000$. The fit-out of John Gray's 260 square metre apartment cost $\$ 80,000$ and the overall purchase price was around $\$ 450,000 .^{12}$

In designing his apartment, Gray was inspired by,

.... a love of brick, a love of voluminous spaces, the scale of the interior, the aesthetic of industrial elements, objects such as theConcertina walls, lifts, windows -(timber double hung), an interest in latches and opening mechanisms, the patina of age and qualities of surface. ${ }^{13}$

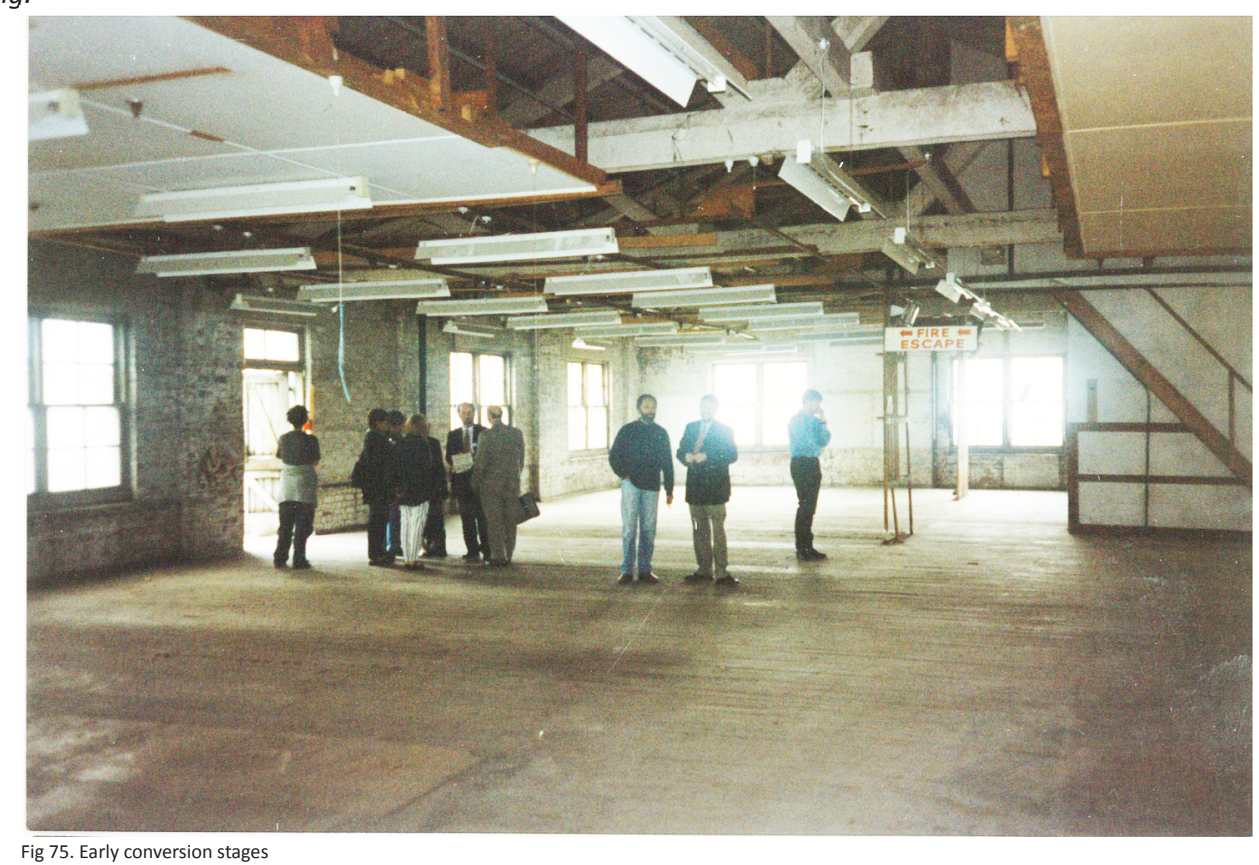

The redevelopment comprised 14 apartments ranging in size from 40 square metres to 260 square metres (with several spanning two or three levels), five offices, retail space, 26

\begin{tabular}{ll}
\hline 5 & Brown, K. "When the Shoes fits". The Dominion Post. October 12 2002, \\
F17 & John Gray personal interview, 2 September, 2011 \\
6 & Hannah Warehouse Prospectus, 1999. Source Victoria Quade \\
7 &
\end{tabular}

There was no reinforcing in the brickwork when the building was first constructed. As part of the seismic upgrade, the brick walls were tied back to the timber floor beams at $8 \quad$ "Chic City pads for the well-heeled." Evening Post. 13 August 1997, 29 9 Hannah Warehouse Prospectus,1999, source Victoria Quade 10 John Gray personal interview. 2 Sep 2011

11 ibid 12 ibid

13 John Gray personal interview. 2 Sep 2011 
certain points by steel rods connected to circular steel plates that distributed the load on to the adjacent brickwork. (This is currently visible on the exterior of the building in the form of red painted discs). The strengthening work that was part of the legal requirement became part of the design aesthetic. There was no need to conceal these structural elements as they were in theme with the design schema. The interior side of the brick wall was tied to the new steel structure using steel studs fixed into the brickwork with epoxy glue.

Windows remained single glazed in order to work with the original double hung timber windows, and where possible to retain the original glass.

\section{Location}

The inner city location of the Hannah Warehouse had mixed appeal. It was close to bars and cafes, yet secluded in the cul de sac of Leeds and Eva streets; in the middle of a block rather than on the street. Therefore, light and sound site aspects were ideal. It was reasonably quiet and well lit as the free standing building had relatively good sized windows on all four sides. Gray and Noble stated the light in their apartment was brilliant.

In the evening the reflection off glass buildings from the north-east gives the full effect of western sunsets. Full sunlight blasts right through to the back wall, sliding down the side wall behind the kitchen and the lift shaft and through the middle where it's filtered by the screens of furniture. Shafts of light from skylights pass through the loft down to the main space below, highlighting the transparency which is vertical as well as horizontal. ${ }^{14}$

However, the location was also near the red light district and prior to the conversion into apartments, when the building was in a state of vacancy, illicit activity was common place. The western boundary faced the rear of a working men's club; a rugged, ugly elevation. The western side was also particularly secluded. Drugs business and prostitution occurred in the vicinity. As Gray stated,

Anti social behaviour-made you feel like you didn't really own what you owned-everybody owned it-what it's like to live in the city-rough part. $^{15}$

John Gray stated in a newspaper article that,

It is for people who want to live and work at home...we have already marketed it among our like minded friends, colleagues and relatives, and now were taking it to the open market.

14 Gaitanos, S. "Let there be Light". Urbis. Spring. 1999, p 52 15 John Gray personal interview. 2 Sep 2011
Residents who have signed up include writers, poets, designers, artists... ${ }^{16}$

He also stated that the building had a beautiful ambience and that he set out to preserve the best qualities of the building; its simple form, honest materials and space.Retaining as much as possible of the character of the warehouse was essential in the reuse of the Warehouse. ${ }^{17}$

An article in 1997 in the Evening Post described the building's best qualities and commented on its likeness to the lofts of New York,

\section{Drawcards include the development's, New York loft-style ambience, extensive use of original brick and timbers from the warehouse, plenty of natural light and convenient downtown location. ${ }^{18}$}

This allusion to New York may have been done to arouse interest in the properties through seeing this comparison as a positive one. Perhaps because this type of living was now well known in New Zealand, the article said "developers have converted the old Hannah's Warehouse in Wellington's Leeds St into a cluster of New York loft-style apartments, studio offices and garages."19

The drawing in Figure 78 was done by John Gray himself, and proposed the concept layout for one of the levels within his apartment. The sketch shows how this particular apartment had direct access via a lift, a free standing kitchen island and most prominently the bedroom area within the space, separated only by a bookshelf. The idea of no permanent walls was prominent in this design, as nothing is segregated off with partitions, rather furniture acts as a space divider.

An article published by Urbis magazine in 1999 stated that Gray designed his inner city apartment to be quite distinct from a suburban home interior. ${ }^{20}$

The lack of a garden area was considered in the design of the large apartments.

To avoid the feeling of being hemmed in, having no garden apart from a small balcony and a roof deck [John] made the perimeter walls function more like the boundary of their lot. The few internal walls seldom meet and none touches the exterior boundary. ${ }^{21}$

It was important to have the sense that you could roam the apartment as though you were

\begin{tabular}{ll}
\hline 16 & "Chic City pads for the well-heeled". Evening Post. 13 August 1997, 29 \\
17 & Gaitanos, S. "Let there be Light". Urbis. Spring. 1999, 52 \\
18 & "Chic City pads for the well-heeled". Evening Post. 13 August 1997, 29 \\
19 & ibid \\
20 & Gaitanos, S. "Let there be Light". Urbis. Spring. 1999, 52 \\
21 & ibid
\end{tabular}


roaming the ground of your property. ${ }^{22}$

The small apartments sold to the general public differed from the larger apartments due to code compliance regulations and because they needed to be sold at a profit. All the floors and ceilings that bordered another apartment had to be fire and sound proofed, hence plaster board was used. Because the apartments had to be sold the design aesthetic was less industrial with its painted over GIB walls. Gray stated that some of the residents wanted their apartments to be quite polished and painted the brickwork. John Gray commented on the smaller apartments differing look.

\begin{abstract}
Naturally, in a smaller apartment on a single level it meant that the two side walls, the corridor wall and the ceiling had to be plasterboard, which consequently shifted the appearance away from the rugged. The floor (timber) and the external wall with its original windows (brick and timber) remained. ${ }^{23}$
\end{abstract}

With regard to selling the apartments he made the following comment.

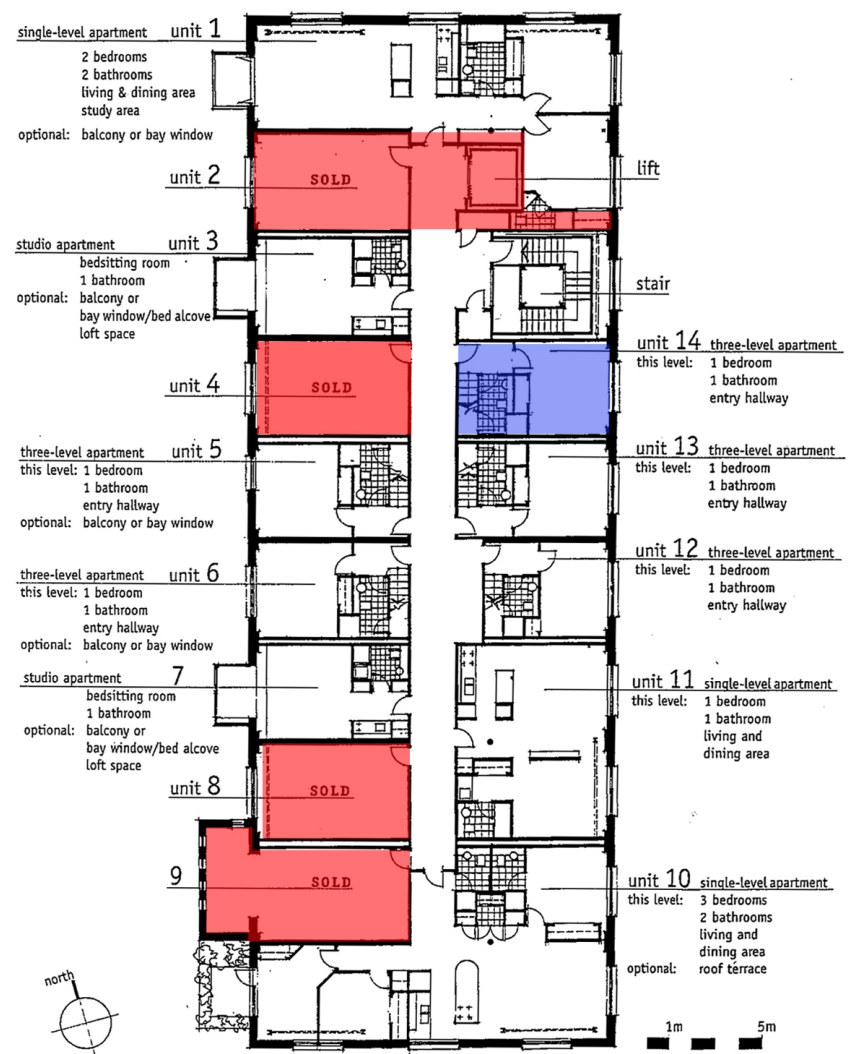

Fig 76. Largest Four apartments that were the originally owned by the investors are highlighted in red. The smaller apartment highlighted blue is referenced in Fig 77. All highlighted apartments spanned three levels.

\begin{tabular}{ll}
\hline 22 & ibid \\
23 & Gray, J. Message to the author.Hannah Warehouse Questions. Email.7
\end{tabular}

The advice from estate agents at the time was that they could market two bedroom apartments most easily. They were wrong. We had a lot of people looking for the very large apartments and the very small ones. The last to sell were the two bedroom three level apartments. The first to sell were the open spaces on level 1 which we sold as 'shells' for people to do their own fit outs. Admittedly they were sold too cheaply, but we had cash flow issues to get over and had to make the sales. ${ }^{24}$

The brick warehouse apartment block was said to be completely quiet even though it was situated in the vicinity of some of the noisiest bars. It was one of the main features that attracted the developers to this building in the first instance. The existing brick walls provided good sound insulation from the outside noise. John Gray's wife, Anne Noble, stated that, "one of the things we loved was that when you came in the middle of the day and stood in these great spaces, you couldn't hear the city." 25

Helen Tippett, a former architecture emeritus professor at Victoria University of Wellington's Architecture Campus was

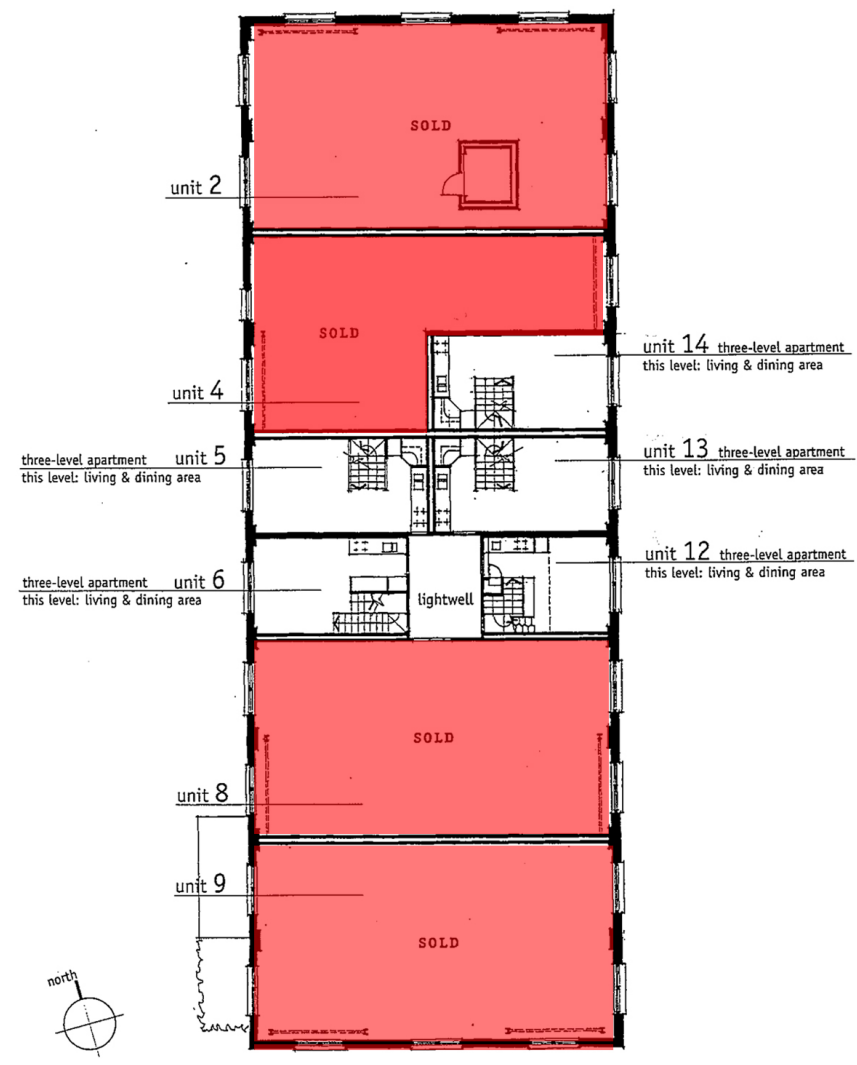

Fig 76.b. Attic level, showing the size of the largest 4 apartments. This is the top level where the bedroom in Unit 2 was situated as of 2011.

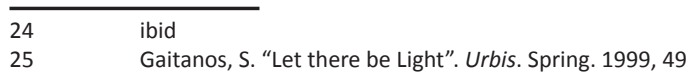


involved in the conversion of the Hannah warehouse from the start, alongside John Gray. She was the head project manager and avid about warehouse living. According to Tippett, apartments in the inner city in the early 1990s were hard to come by. ${ }^{26}$ Interest in inner city living proved popular after the redevelopment of the first Office and Warehouse refurbishment: the Wharf Building at 1 Queens Wharf, which had belonged to an earlier industrial age. The building was originally used as offices by people managing the warehouse. In 1994 it was converted into apartments and offices and is currently housing the New Zealand Academy Of Fine Arts.

.27 It was designed by Frederick de Jersey Clere in 1896, the same architect whose work was referenced as precedential in the Shed 21s design. According to John Gray, during this time there was almost no one living in the city, maybe at most 50 people. ${ }^{28}$

At the time, the Queens Wharf former warehouse and offices was being considered for redevelopment into apartments and the advice given by real estate agents was that no one would want to buy an apartment in town. The Waterfront development went ahead with a group of Wellington architects deciding to draw up some plans to see if there would be any interest. All the proposed apartments were sold in 3 weeks from these plans. This opened up a floodgate for inner city living and reuse of vacant buildings. ${ }^{29}$

\section{Design approach}

Prior to living in the warehouse Tippett lived in a house in Kelburn, but wanted to live in the heart of Wellington City, stating her previous house felt like, "living in Home Beautiful". The four storey warehouse had generous volume and light. Inside her $250 \mathrm{sq} \mathrm{m}$ apartment, Tippett chose to paint the brick Half Spanish white throughout. ${ }^{30}$ Tippett also stated that she wanted straightforward honesty, hence there

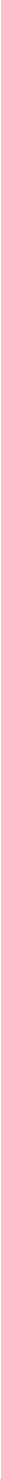


was a lack of curtains, which she stated were "superfluous". The idea not to hide and reveal elements was also part of the exposed aesthetic prevalent in her apartment, "what's there is not hidden-from the extensive, eclectic art displayed throughout to ten towels hanging on a Resene Berry Red kitchen cupboard." 31

One of the most interesting outcomes with the Hannah's Warehouse and Hannah's Factory apartments was the small amount of internal work that was done. Tippett said that she fell in love with the space the building gave and stated that, "as an architect you can provide two things, space and light and the rest is personal preference". ${ }^{32}$

A sense of community was also established with the renovation of this quarter as Helen Tippett's daughter stated.

You can wander out and become part of a community. There's no isolation, no suburban isolation. $^{33}$

A communal area was, however, never formed architecturally.

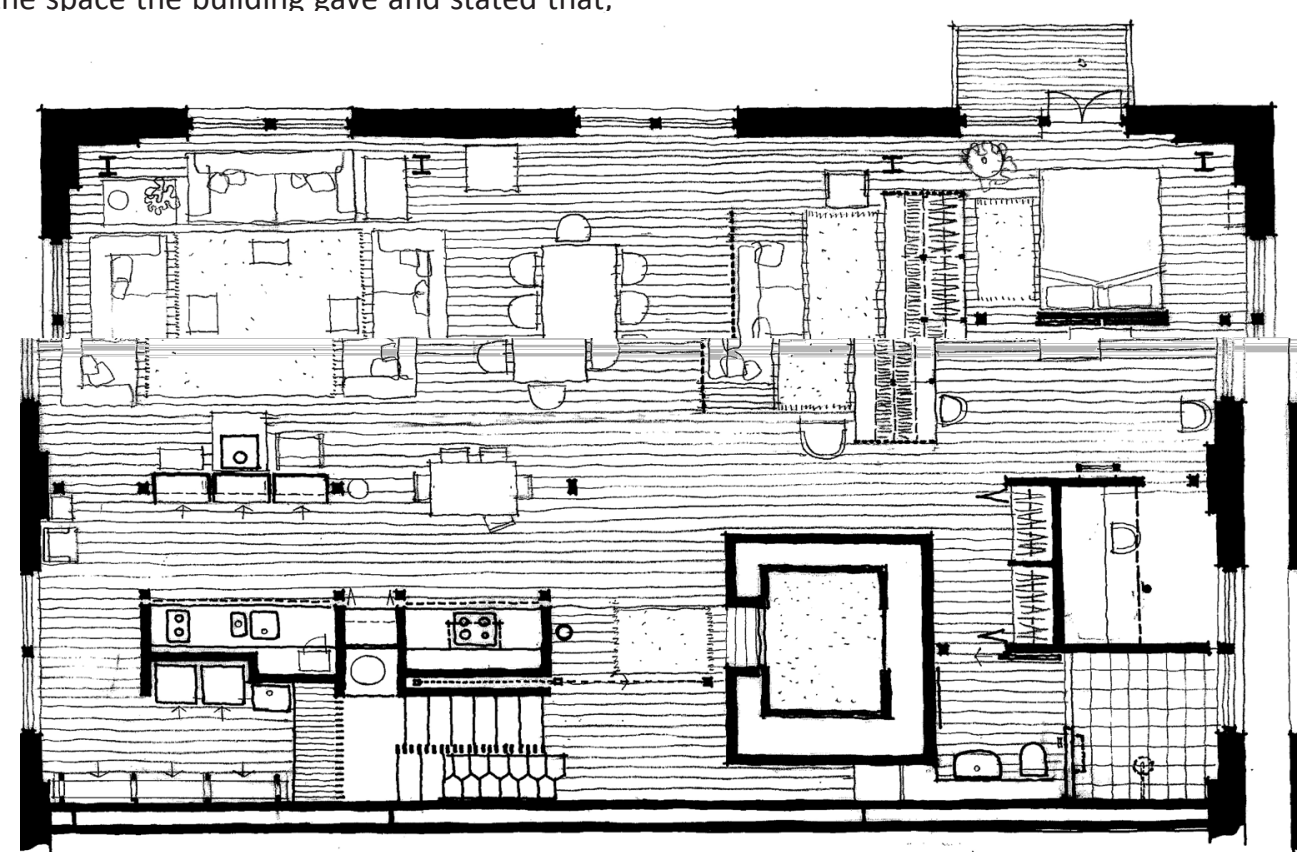

Fig 78. Layout sketch by John Gray of his former apartment-living area level. The bedroom was initially positioned on the same level as the dining space, before being relocated to the Attic level.

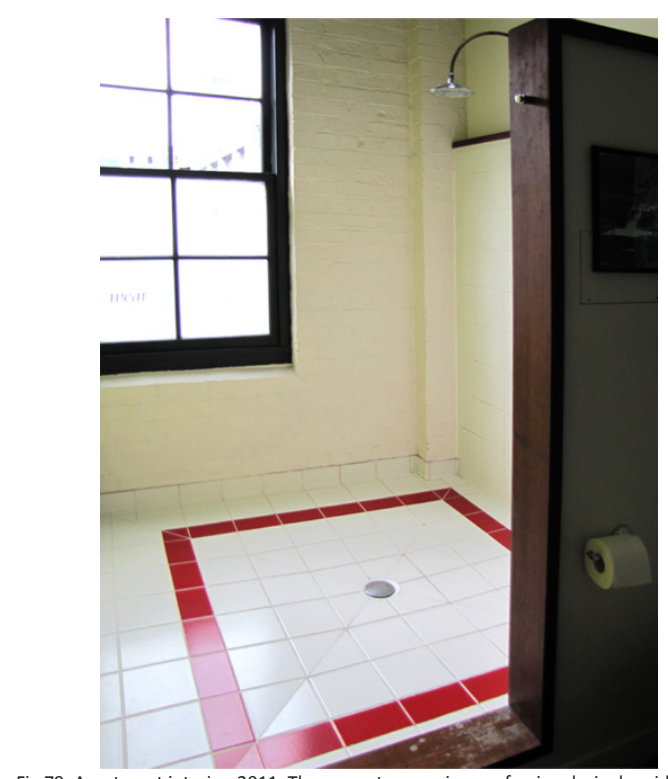

Fig 79. Apartment interior, 2011. The current owner is a professional, single middle aged male.

31

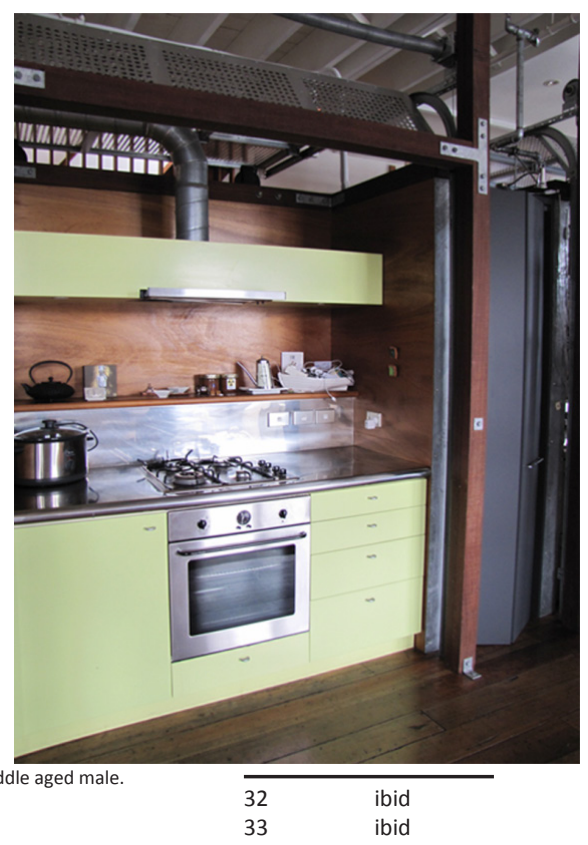

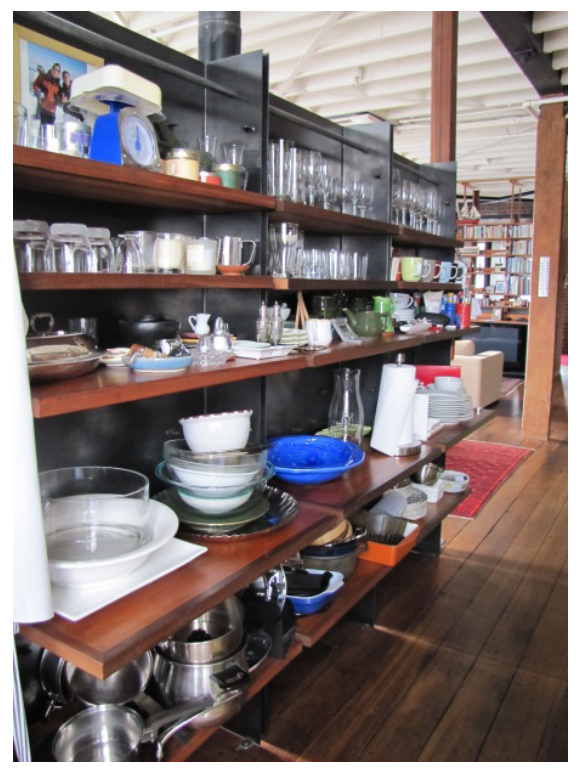



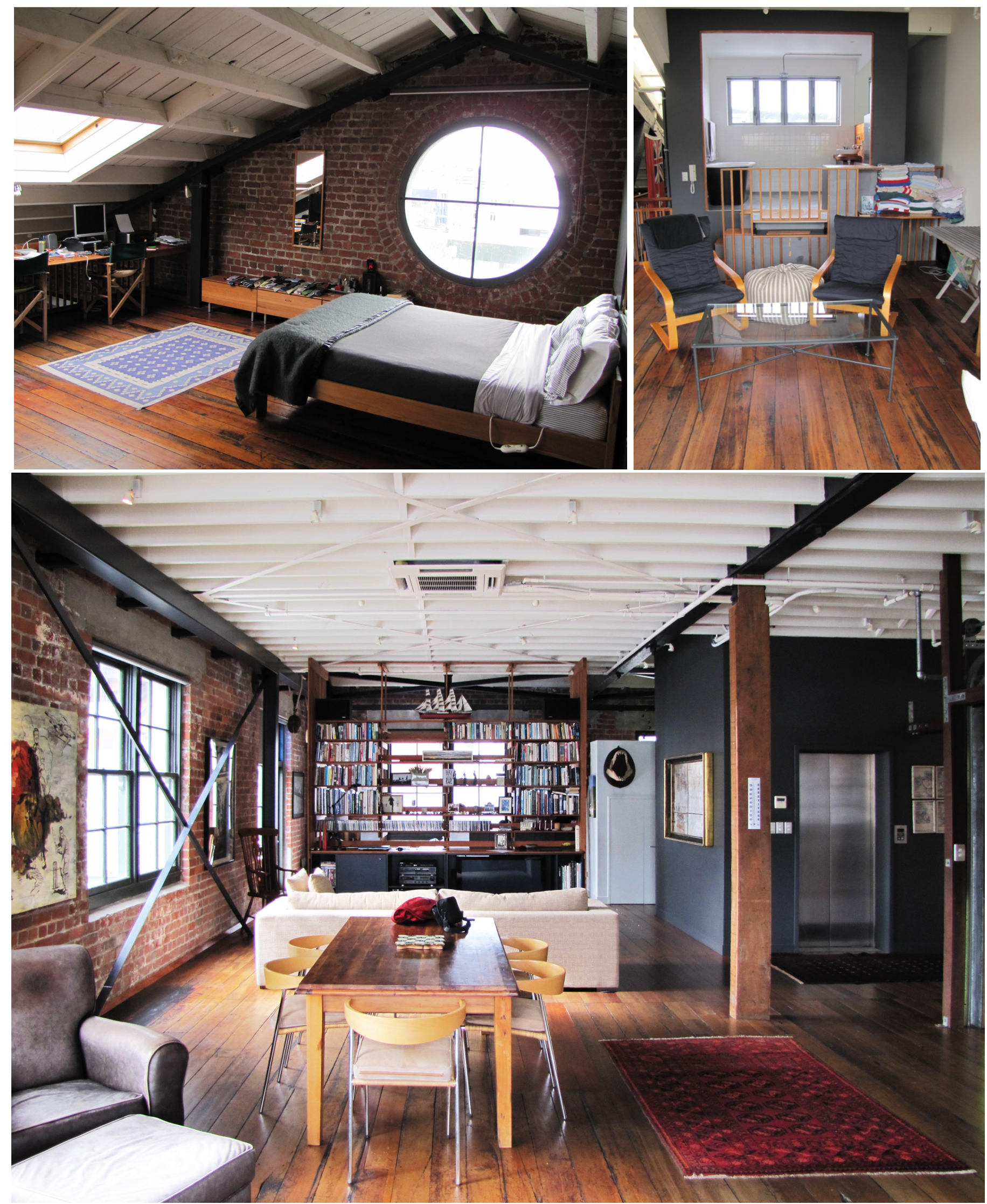

Fig 80. Apartment interior, 2011. Bedroom with open bath area top right. Elevator opening at living area bottom image. 

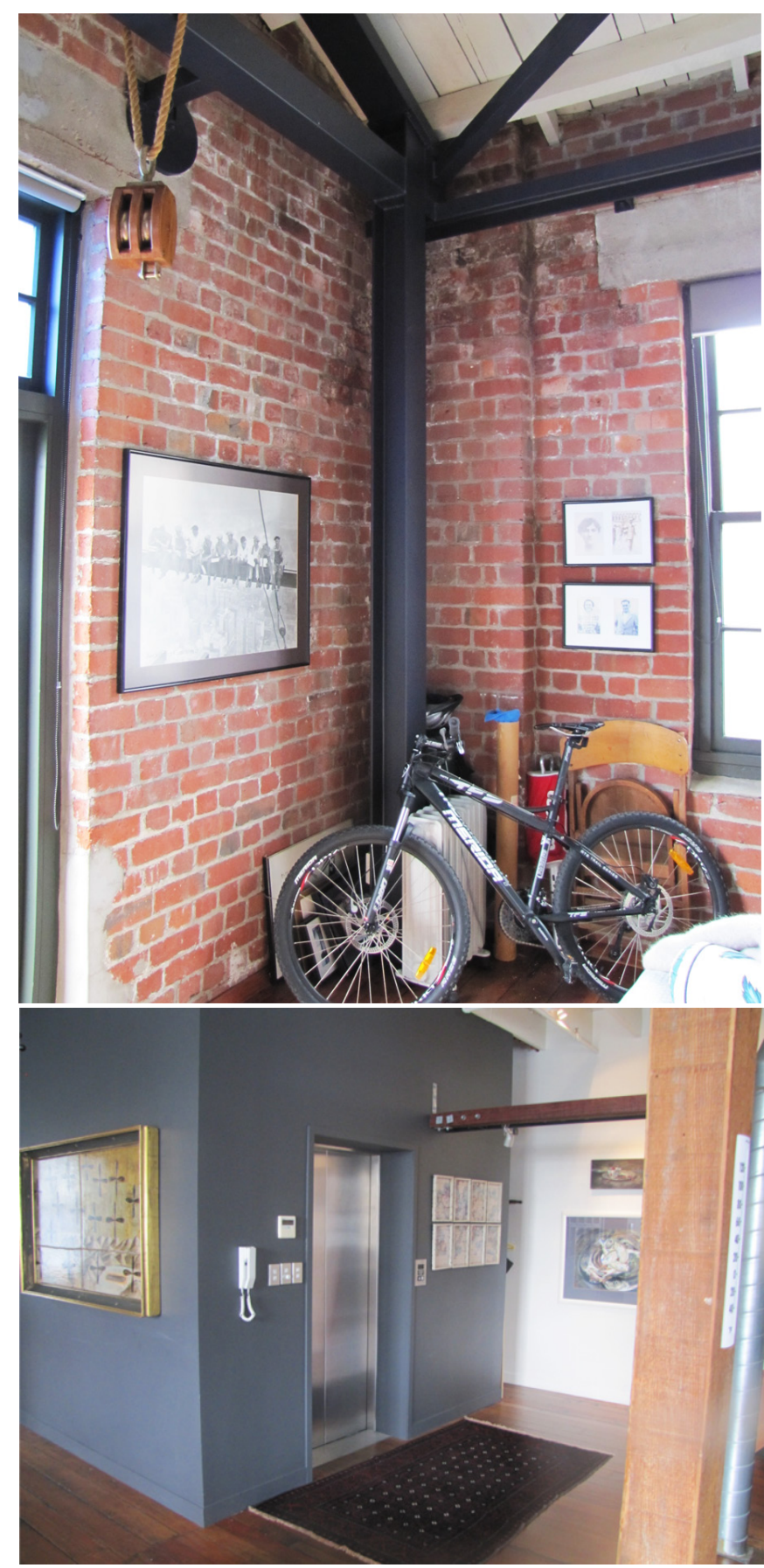

Fig 81. Interior showing traces of heritage and exposed and untouched surfaces and elements.

One article stated that the Hannah Warehouse was being developed in conjunction with a community square that would become a public space under Wellington City Council ownership. John Gray was interested in developing the area surrounding the Hannah buildings and creating a communal area that would integrate landscape architecture, new paving, seating and a very restrictive vehicle access. However, this was not taken further than the conceptual stage as there were disagreements with the developer of

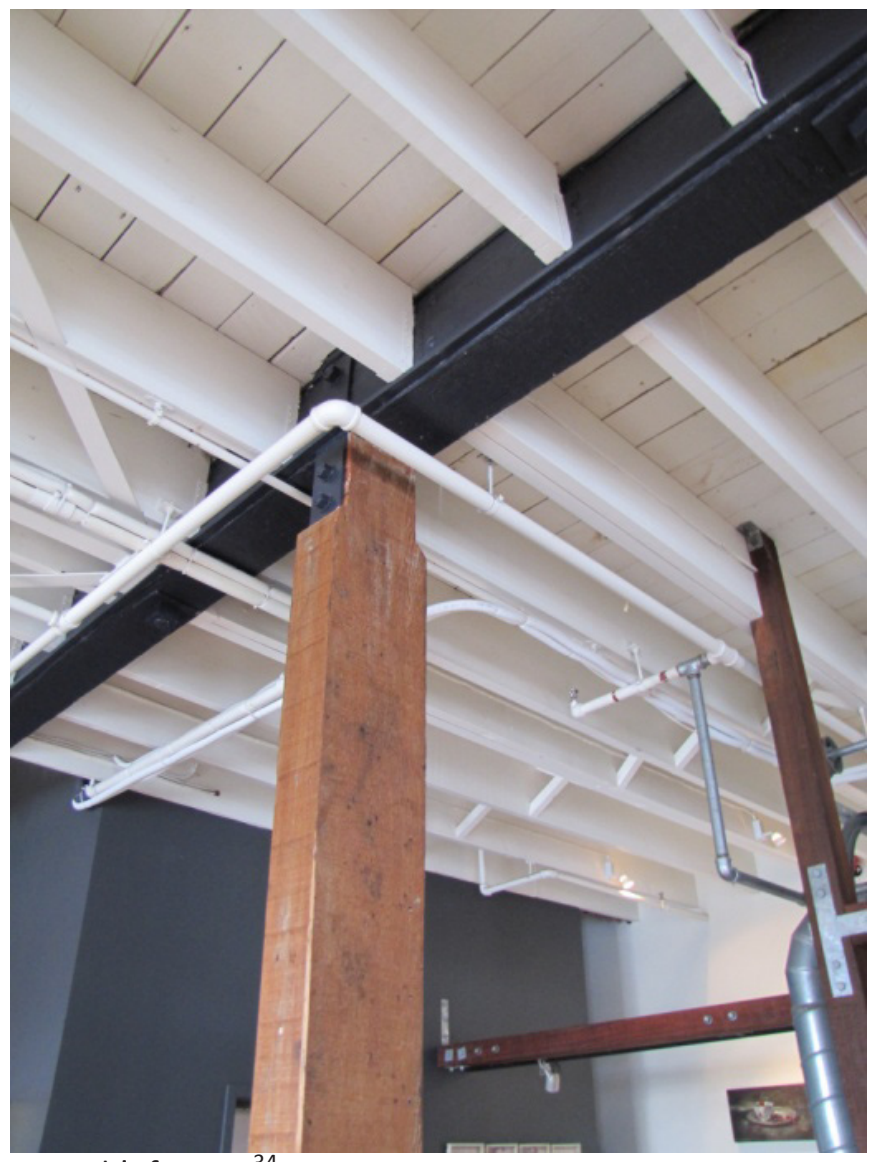

Hannah's factory. ${ }^{34}$

\section{Kitchen}

The two concepts that drove Gray's design for his apartment were ideas about what distinguishes an inner city apartment, and the nature of the Hannah warehouse with its century of history. ${ }^{35}$ The warehouse was found in a completely open state on every floor with only the shoes racks remaining. Also in keeping with the traditional loft look they created partitions and 'spaces' by using large furniture to divide space instead of walls. The spaces were left transparent, which primarily relates to the spaces being left open and divided by large pieces of furniture, such as bookshelves and a high backed couch, constructed from timber recycled from other parts of the building.

These items roll on in line with one another down the centre of the apartment, just like the original storage racks...some of these objects are filtering so that you see through them. ${ }^{36}$

This idea of transparency continued into the bathroom and the kitchen. In terms of the materials used, extending this aesthetic to spaces like the bathroom and spacious shower $34 \quad$ Gray, J. Message to the author.Hannah Warehouse Questions. Email.7 Sep 2011

35 Gaitanos, S. "Let there be Light". Urbis. Spring. 1999,49 36 ibid 


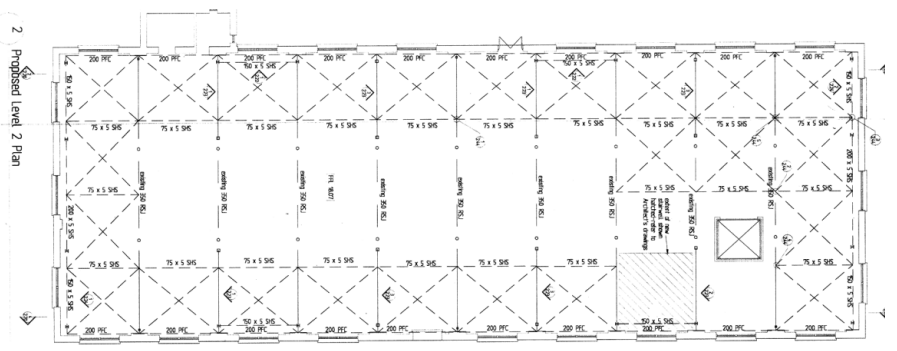

Fig 82. Cross bracing to underside of floors

was considered to be quite shocking by some. Athfield stated,

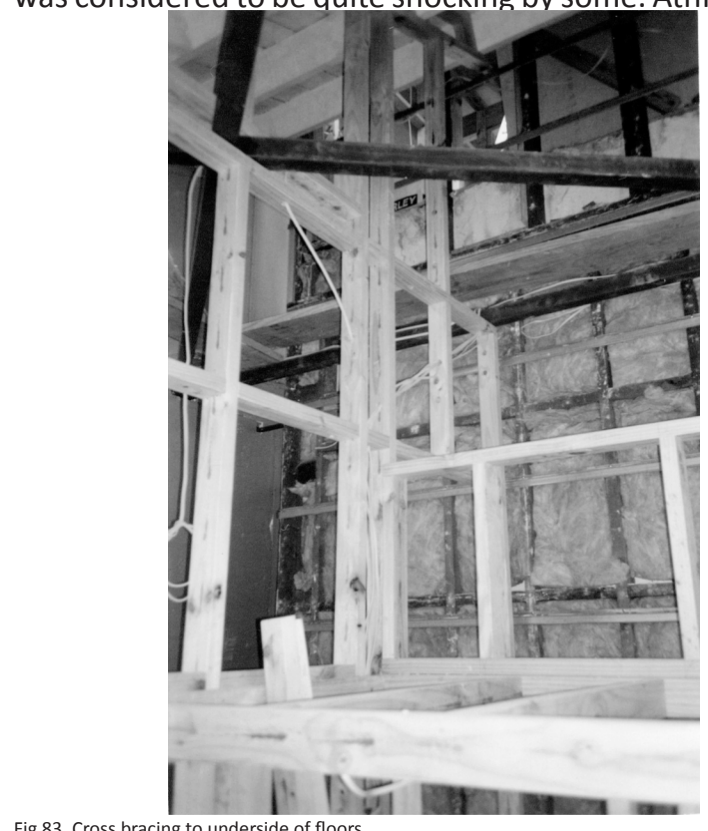

however that, "if you want privacy, just close your eyes"37 something that Gray agreed with.

In the kitchen the idea of transparency continued in Gray's apartment, with the complete absence of cupboards, most notable in the side-by-side kitchens (one for snacks, the other for serious cooking)..$^{38}$ Instead of cupboards the apartment's kitchen was designed to have garage roller doors made of perforated metal, which could be rolled down when desired. Anne Noble stated that living without cupboards changed her attitude towards things, "there's nowhere to hoard anything, so you have what you need in the appropriate place or get rid of it." ${ }^{39}$

John Gray added window film to some of the East facing windows as a way to provide some privacy without resorting to curtains but at the same time added a creative touch and tribute to the building's past. The words on the film were old

\begin{tabular}{ll}
\hline 37 & ibid \\
38 & ibid, 52 \\
39 & Ibid, 53
\end{tabular}


names of shoes that Hannah used to manufacture. ${ }^{40}$

The exposed kitchen and living space in the design of both the Hannah Warehouse and Athfield Architects' Hannah Factory followed the trend that was paramount in the SoHo, New York warehouse and loft spaces. As Richard Kostelanez a former SoHo resident and literary artist stated,

As open interiors became the ideal, the typical SoHo kitchen would be exposed to the larger space, rather than hidden behind a door, sometimes kitchen utensils would be exposed as well, rather than hidden behind cabinets. ${ }^{41}$

The bathroom on the mezzanine level was left completely exposed and was unaltered by the most recent owner of what was Gray's apartment. There is a complete absence of curtains and shielding. The floor is also timber, continuing the aesthetic of the level below.

Wall to wall carpeting was unheard of in the SoHo aesthetics.

While small rugs were permissible here and there, the uptown apartment fashion of "wallto-wall carpeting" was almost unknown. Even in lofts that could have used more floor insulation or warmth, the custom was a wooden floor, ideally well polished. ${ }^{42}$

\section{Extra Costs}

According to John Gray, a 2 metre diameter stormwater culvert ran under the building at an angle of around 30 degrees away from the east-west direction, a bit north of the middle of the building. It was built around the 1880s, and made of unreinforced brickwork. It took the water of the old Te Aro stream, and discharged it to the harbour under the Odlin's building on the waterfront.

When reuse work began on the Hannah Factory which sat directly above this culvert it caused extra problems both structural and economic, especially related to the addition of the new car park levels at ground level.

Gray stated that upon digging down a metre for the lower level they came across the two large bridge structures that spanned across the culvert that also took the load of two cast iron columns which would otherwise have gone straight through it.

The trouble was that the tops of the bridges were too high for our car park to work so we set about to remove them and put in less deep steel

\begin{tabular}{ll}
\hline 40 & John Gray personal interview, 2 Sep 2011 \\
41 & Kostelanetz, R. Soho: The Rise and Fall of an Artist's Colony New York. \\
& 2003. Print. \\
42 & Kostelanetz, R. Soho: The Rise and Fall of an Artist's Colony New York. \\
2003. Print. &
\end{tabular}

beams to take the load of the columns. Trouble was, the city engineer was concerned that any vibration resulting from the demolition of the concrete would possibly break the culvert, and result in massive flooding and destruction through the lower part of Te Aro. The builder solved the problem by getting a rope studded with industrial diamonds that (when wrapped around the beam) could be used to cut the concrete into small enough bits that could be carefully removed. I think from memory that this cost an extra $\$ 60 K$. $^{43}$

The Hannah Warehouse was marketed by Susan Gordon of Challenge Crowther realty. She had lived in apartments most of her life including in New York and saw the likeness of this development to New York lofts and warehouses, "When I see apartments advertised as New York-style it annoys mebecause they're not. But this development is." 44

In John Gray's former apartment initially had the bedroom space on the same level as the living lounge and kitchen area. The entire plan was left open without any partition walls. There was a guest bedroom situated on the lower level of the apartment. Gray felt that guests would be uncomfortable living in an open area and that his bedroom area would be shocking to most people, as it was unusual and unfamiliar, "not common in the kiwi culture". He also stated that New Zealanders were less comfortable with living without carpeted floors due to their conservative culture. ${ }^{45}$

\section{$\underline{\text { Removal }}$}

Because the original building was so open on each level little demolition work occurred in this project. The roller doors were removed from the exterior as was the shute and internal stair and fire escapes. The stair that was removed was salvaged for reuse. An existing fire place was removed at level two as well as the piping and plumbing and toilets. There was an external fire escape on the west external face of the building which was also removed. ${ }^{46}$

\section{$\underline{\text { Insulation and Acoustics }}$}

Sound insulation was provided in the form of $75 \mathrm{~m}$ pink batts inserted bewteen the fyreline $100 \mathrm{~mm}$ steel studs and clad in two layers of fyreline $9.5 \mathrm{~mm}$ thick on both sides of a double stud wall between each apartment, and an acoustic sealant.

The fyreline GIB board on ply ceilings were inserted between the three levels. Recycled flooring was used over the Gib in several sections. There was an air separation gap as well

\footnotetext{
$43 \quad$ John Gray personal interview. 2 Sep 2011

44 "Chic City pads for the well-heeled". Evening Post. 13 August 1997, 29 John Gray personal interview. 2 Sep 2011

Watt Architect Plans, Don Thomson Consulting Engineers Ltd, 28 May

1997. Wellington City Council Archives. Wellington. 1 Sep 2011. CD
} 
as batts between the two walls which helped with sound proofing and provided sound insulation.

Partitions above level three were timber. The recycled flooring was reused to create the mezzanine level in the loft area where the bedrooms were located in the larger apartments.

\section{$\underline{\text { Fire protection }}$}

The gib fyreline walls were attached on either side of the columns. Sound transmission was also prevented in the walls by separating the plaster off the timber by hangers creating a very small amount of connection. ${ }^{47}$

The Fyreline GIB, used on the walls, floors and ceilings to comply with fire safety regulations, diminished some of the quality and aesthetic visible in the larger apartments, which unlike the smaller ones were built as largely free standing and open plan living. There was a distinct discrepancy between the look of the larger apartments 2,4,8 and 9, and the smaller ones that were only one or two bedrooms and that were fire rated on all sides. Intumescent paint was also added to the steel beams and columns. Apartments 1,3,7,10,11,13 were single storey with fyreline ceilings, whilst apartments $2,4,5,6,8,9,12$ all had existing floor joists and flooring exposed.

\section{$\underline{\text { Recycled Materials }}$}

The recycled timber floor was set on the existing rolled steel joists on levels two and three, and these joists were left exposed on the underside of the ceiling. This was intentionally done, again adding to the industrial quality the architects set to out to achieve. A concrete slab on hibond was inserted at the parking level creating this new additional level.

Bathrooms at level one had existing Tongue and Groove flooring removed and refitted with $18 \mathrm{~mm}$ firred ply.

To waterproof the building the damaged cracked bricks were repointed and repaired, and coated with an industrial waterproof compound-like paint.

The existing lift was retained and provided a direct entry route into apartment 2, Gray's former apartment.

\section{Structural Upgrade}

At the time of the building's reuse in 1996 it was constructed to 70 percent of the at the time current Building Code seismic requirements. A steel cage runs right around the perimeter of the warehouse forming an entire enclosure. Existing columns in every bay had new beams inserted to run across as well as steel hollow section cross bracing. The ground the $47 \quad$ John Gray personal interview. 2 Sep 2011 building stands on remains subject to liquefaction, meaning the building will tip in an earthquake but remain intact as a unit; the bricks will fall off, but the frame, structure and floors will remain intact. ${ }^{48}$

Gray stated that when converting the Hannah Warehouse, the compliance with the building code meant that much of the open space was lost. Ideally Gray would have left the spaces bare and without any walls, however, due to seismic requirements, walls had to be inserted. New York City regulations on earthquake strengthening differed from those of New Zealand, allowing for a much more open planning compared to the New Zealand examples. ${ }^{49}$ The earthquake strengthening work that was a requirement as part of the redevelopment acted as a feature with its exposed structural steel inside the brick facade.

According to Tippett, good quality urban development comes down to respecting a building's integrity and she "didn't want to muck around with the bones of the building." 50

$300 \times 50$ bearers bolted to brick grids were inserted onto the interior of the brick external wall. The wall of the existing brick basement was demolished down to a level to suit the newly inserted concrete footing and foundations.

A 250 wide UB (universal steel beam) was inserted around the interior perimeter at parking level 2 and a 200 PFC (parallel flanged channel steel structural section) was inserted around the internal perimeter at Level 1 and through to the truss level.

The concrete slabs at the perimeter edge of the car park level were also thickened to $300 \times 200 \mathrm{~mm}$.

Don Thompson Engineers did an 'Initial Evaluation Procedure' in 2007 to determine the current structural state of the building. According to them, the building was strengthened to 2/3 of the 1965 code. In 1996 Don Thompson Engineers were engaged to design a steel structure that complied with the regulations current at that time.

The design principle at the time was to provide two separate load resisting parts. One part would carry the seismic load, and a second set of structural elements would carry the gravity load. With this separation, the seismic elements were designed with a higher ductility allowance than where a single structural system was in place. In addition to this, the earthquake loads were reduced because the building's expected use duration was considered to be shorter than

\footnotetext{
$48 \quad$ John Gray personal interview.2 Sep 2011 49 ibid

50 Brown, K. "When the Shoes fits". The Dominion Post. October 122002
} 

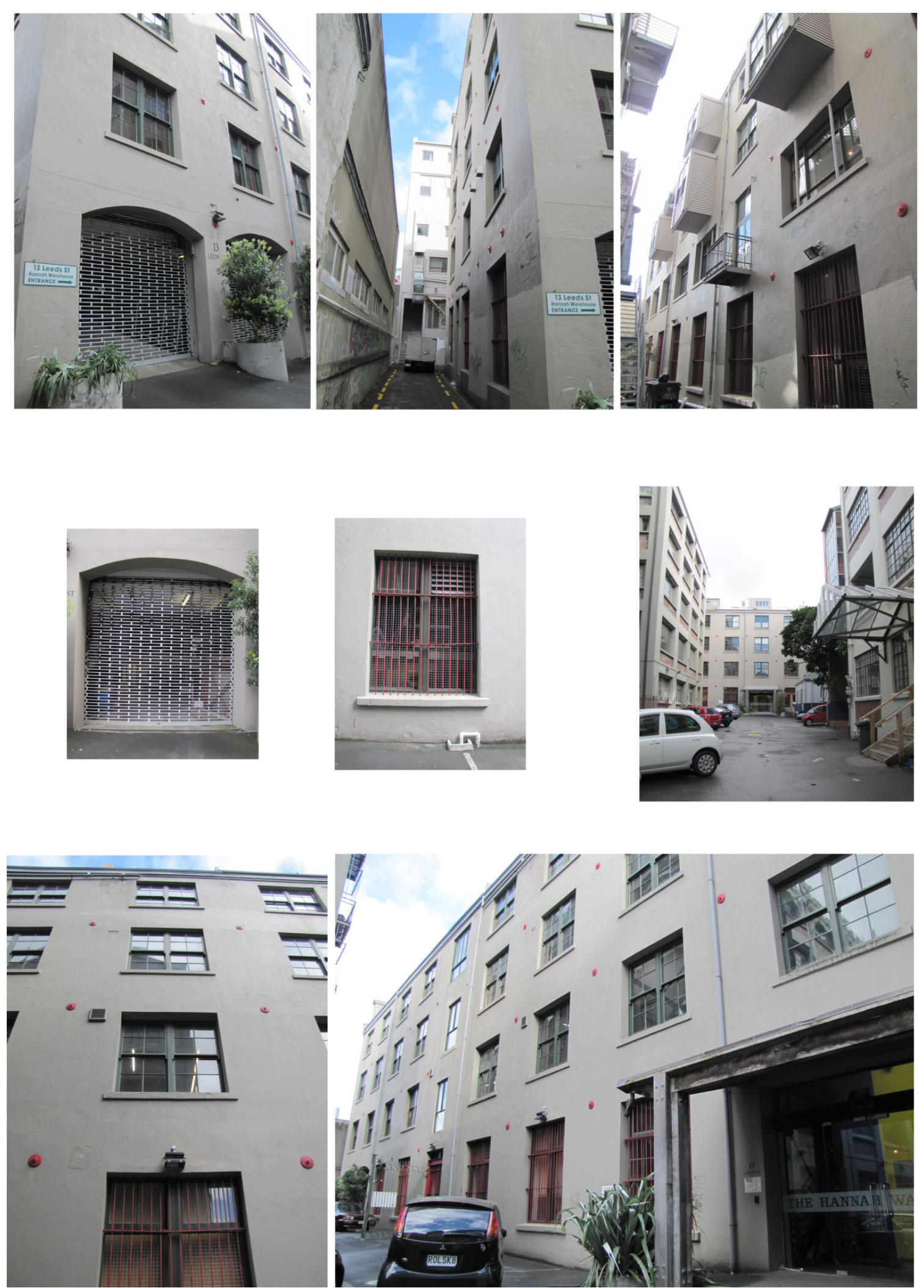

Fig 84. Structural upgrade of existing brick wall visible, in the form of the red disks. Because the external walls are essentially brick without a concrete frame or being set in bond and acting purely as a external cladding, the building is not very secure structurally and more earthquake prone than the Hannah warehouse. 
if it were a new building. ${ }^{51}$

Don Thompson Consulting Engineers also noted that, ...the building has a $47 \%$ compliance with
current regulations, but that there will be
significant damage to the brick veneer in
an earthquake. Since the building has had a
greater level of compliance than the minimum,
it does not require further strengthening under
current WCC regulations.

\section{$\underline{\text { Insurance }}$}

After $9 / 11$ the insurance premiums for property went up. Prior to this event the Hannah factory residents paid $\$ 18,000$ pro rata spread among owners. This subsequently increased to $\$ 84,000 .^{53}$

$$
\begin{aligned}
& \text { John Gray stated, } \\
& \text { The insurance for a large building like this } \\
& \text { cannot be obtained from a local/national } \\
& \text { insurance company, only offshore. After } 9 / 11 \\
& \text { the insurance companies were trying to recover } \\
& \text { the huge payments that } 9 / 11 \text { incurred, so they } \\
& \text { hugely increased premiums. Our premium went } \\
& \text { from } 18 \mathrm{~K} \text { to } 83 \mathrm{~K} \text { in one year. The insurance } \\
& \text { broker tried to argue that the upgrades to the } \\
& \text { building made it the equivalent quality and } \\
& \text { strength of a new building, but that didn't go } \\
& \text { over with the insurers, who insisted that it was } \\
& \text { a 'brick building in an earthquake risk zone' and } \\
& \text { therefore a big risk for them. }
\end{aligned}
$$

As with the adjacent Hannah Factory conversion, the industrial aesthetic and design were and still remain revolutionary and alternative to the modern, clean and polished look prevalent in post 1960 apartments. The abundance of bare walls and exposed brick, exposed circuits, strengthening work and a lack of carpeting and wall paper comes down to personal and individual taste. Witold Rybczynski stated that personal preference and therefore an individual idea of comfort is based on cultural preconditioning, something people have been brought up with.

Comfort is simply a verbal invention...lt is an invention, a cultural artifice...The recognition [of comfort] involves a combination of sensations, many of them subconscious-and not only physical, but also emotional as well as intellectual, which makes comfort difficult to explain and impossible to measure. ${ }^{55}$

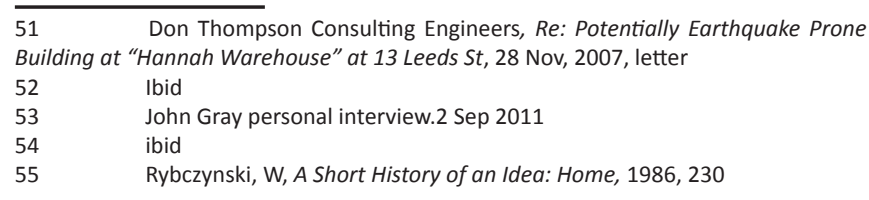

He also reiterates that the idea of comfort is something that is unique to each individual, which would explain why some people prefer to live in a building with a certain aesthetic, even one considered less common.

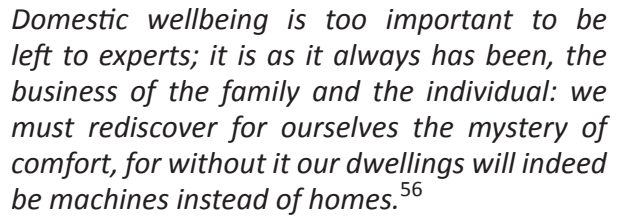

Factory and warehouse buildings usually make good candidates for conversion based on several criteria that were prevalent in both the Hannah Warehouse and the Hannah Factory. Both had a general lack of permanent interior partitions allowing easy manipulation of interior spaces into units without demolition. This also made the installation of services such plumbing and electrics easier and cheaper to install. The relatively large and numerous windows allowed for maximum light penetration from four sides as both buildings were free standing.

\section{Conclusion}

A good building candidate for conversion largely depends on the cost of compliance work. An ideal warehouse to convert into residential living would be a one or two storey structure that is already reinforced and complies with earthquake codes because the structural upgrade alone is worth a lot of money. ${ }^{57}$ However, the codes change every two years, and as a result of Christchurch, laws get tougher every time. This was witnessed in several historic Wellington buildings that were previously unreinforced brick and have had to be structurally upgraded to be usable once again, the former 132 Cuba Street Ernesto Cafe being one such example. ${ }^{58}$ However, when the conversion is achieved the results can be stunning, as was witnessed with the several examples in this thesis.

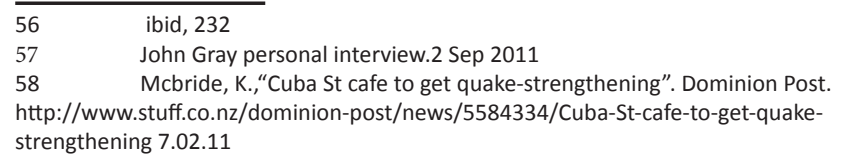

57 John Gray personal interview.2 Sep 2011 strengthening 7.02.11 


\section{Comparison and Discussion}

This chapter will compare and discuss the four Wellington case studies based upon the conversion criteria in each chapter, and how they differ. This chapter will also discuss the parallels and differences in the emergence and history of the loft living phenomenon in SoHo, New York and Wellington, New Zealand.

The assessment of the success of each of the four converted buildings is complex, as each varies based on external factors and the political, social and economic environment surrounding the building at the time of its conversion. All of the four case studies were converted at different times, 1994 being the earliest and 2005 the latest, therefore, the state of the city itself also had an impact on the conversion work.

The Hannah Factory was the first known example of an inner city factory to apartment conversion. The property developer had a scheme, which was both experimental and evocative, testing the idea of living in the city centre, which was at the time an unfamiliar concept in the Wellington market. ${ }^{1}$ Athfield architects, John Hardwick Smith and Zac Athfield stated that, "the project was raw, urban and had a lower value, therefore the return on investment was not perceived to be as high." ${ }^{2}$ The demographic the Hannah Factory apartments were marketed to were young, creative types, of varied social status. Students, artists, young professionals and those wanting to live in the city centre, were targeted as potential buyers. ${ }^{3}$ The project was successful because it introduced a public thoroughfare through the two converted buildings, thus providing a new urban connection.

Unlike the Hannah Warehouse and Factory which were located in the inner city Te Aro area, Odlin's Building and Shed 21 were both located on the waterfront, an area that was closely regulated and overseen by the Wellington City Council, the Lambton Harbour Management Ltd and the Wellington Waterfront Framework group. These buildings therefore had to succeed economically and publicly, complying with a stricter framework. Athfield Architects felt these projects were much more political, and pitched to a wealthier and a more conservative market, as the architects were pressurised to make a higher value product. ${ }^{4}$ Both of the waterfront projects arose from a Waterfront competition, and had to reach a high economic yield.

Political constraints meant schemes which were more

\begin{tabular}{ll}
\hline 1 & Cassels,I., director of Whats New Co. Ltd. Personal Interview, 12 May, \\
2011 & Athfield. Z., and Hardwick-Smith J., Personal Interview., 11 November \\
2 & \\
2011 & Cassels,l., director of Whats New Co. Ltd. Personal Interview, 12 May, \\
3 & \\
2011 & Athfield. Z., and Hardwick-Smith J., Personal Interview., 11 November \\
4 &
\end{tabular}

experimental were rejected..$^{5}$ However, it was vital to preserve the sense of history of the building. Because both of the waterfront buildings were part of a larger development of the Wellington waterfront and port area, and because both of these buildings were registered as Category 1 under the New Zealand Historic Places Trust (NZHPT), the interventions had to maintain as much of the buildings existing framework as possible. The Wellington City Council, Lambton Harbour Management Limited, and the public closely moderated and had input into potential interventions. ${ }^{6}$

Because the Hannah's Warehouse and Factory were located in an urban cul de sac and were unregistered buildings, they were hidden away and hence less well known. The Hannah Block area, previously deemed unsafe and infamous for illicit activity, became a more civilised neighbourhood, and community area. The lack of classification and registration of both of the Hannah's buildings, and both being under private ownership, mean the owners and developers therefore had more freedom in their modification and conversion. The final look of these buildings varied greatly compared to the waterfront warehouses. Political influences therefore, ended up playing a large part in the architectural and design outcome of the converted buildings.

\section{Demographic}

As mentioned, some of the greatest differences between the Odlin's Building and Shed 21, and the inner city Hannah's Buildings conversions, were the developers' approaches, the existing location, and the demographic of potential residents. The developers of Odlin's, Willis Bond, and Shed 21, Newcrest Holdings Ltd, both had a large input in the overall look of the buildings. Both of these companies had a well established low risk brand, with which came a recognized look, and aesthetic renowned in their all of their projects ${ }^{7}$ expected by potential buyers of the apartments. Their demographic targeted clients who were older, with a higher wealth. Many of these residents already had homes and were looking for an apartment of a similar finish and overall look. The Odlin's apartments were all sold off from plans, reinforcing the idea that the client had a good understanding of the work that would be produced by the development company associated with the conversion.

\section{$\underline{\text { Historic Preservation }}$}

Shed 21 had a Category 1 Classification. The existing building's architecture and form was assessed to have great historical importance and was therefore to be preserved as much as possible, whilst integrating a new programme within the building.

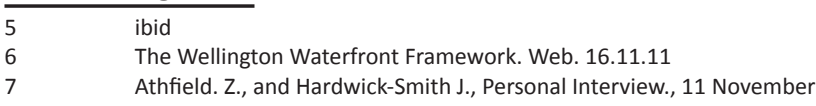


The conversion of Shed 21 was one of the most successful as far as having the least amount of alteration done to the building. Externally there was little modification, and rather than being altered it was repaired and restored as much as possible. In this conversion, individuals building elements were thoroughly assessed based on their importance, and repaired, replaced or maintained as an outcome. The heritage assessment report put together by the NZHPT for Shed 21 specifically stated that repair was favoured over replacement. The external facade was not greatly altered and brick was repaired and repointed but left unpainted.

The Odlin's Building also received a Category 1 Classification from the NZHPT. It was given a Historical Significance evaluation because C. \& A. Odlin Ltd was considered important to New Zealand's commercial history. ${ }^{8}$ It did not receive recognition under the Physical Significance or Cultural Significance categories and this may be the reason for the large number of architectural changes that were made during conversion. As the architects stated, the conversion was more about preserving the scale and bulk of the building as opposed the finer details such as the seaward façade, which was dramatically altered. ${ }^{9}$ Of the four buildings, Odlin's has the fewest qualities that would suggest it was a converted factory space. Internally it is not unlike a modern apartment with few qualities of age, and original materiality and layout.

Unlike the waterfront warehouses, the Hannah's buildings were not registered or historically important buildings. This lack of registration could have been crucial in their much more open and experimental conversion.

\section{Size and Layout}

Economic pressure from the developers and real estate agents was a big driver for the eventual size and number of apartments in each converted building. The developer of the project calculated whether it was cheaper to build more smaller apartments or build fewer larger apartments that would cost more to buy. The developer would also receive data and advice from real estate agents, who would notify the developers about what sold previously and current trends and requirements of potential buyers. ${ }^{10}$

In each of the four case studies the existing structural grid set the layout for the new apartments. These are rectangular and linear in form, corresponding to the rectangular shape of the buildings. The larger apartments in Hannah Warehouse, Hannah Factory and Shed 21 have the most open plan space, and are thus most similar to a SoHo loft. The larger apartments also had the greatest freedom to change the $8 \quad K e l l y$, M., Odlin's Building Statement of Significance for Wellington City Council. Wellington City Council Heritage Inventory. NZHPT. 1995

$9 \quad$ Athfield. Z., and Hardwick-Smith J., Personal Interview., 11 November layout of the spaces, especially in the Hannah Warehouse, which had no permanent walls in the lower level. A common trait of all four case studies was the idea of having the bedrooms located on a mezzanine level, and keeping the more public areas open plan. The apartments that were larger and had more bedrooms would sometimes have the bedroom incorporated into the open plan, but the guest bedroom would be separate.

\section{Kitchen, Bathroom and Furniture}

The more conservative Waterfront Shed 21 and Odlin's buildings used materials that were fashionable at the time for the benches, cupboards and joinery units in both the kitchen and bathroom spaces, which included, melamine coated mdf board, and gib board, reflecting inexpensive and popular interior design trends at the time of the conversions. These kitchens were simple and standard. The specification was very detailed, specifying in detail the type of cutlery system, and the brand of fridge and waste disposal unit. Odlin's included a pantry adjoining the kitchen space where wine and food was stored. Shed 21 also had a large wine cellar unit installed by the residents. Again spaces such as the pantry and wine storage showed how the planning of the apartment was based around the specific type of resident's needs, but also how little amount of decision making the future resident was involved in.

All four converted buildings apart from the smaller Hannah warehouse ones, had island style kitchens that were part of the open space living and dining area. The smaller Hannah Warehouse apartments also had open plan kitchens, however they were fixed to one wall.

The kitchens in the Hannah's Factory worked alongside the overall design scheme and building aesthetic, incorporating raw industrial, experimental, exposed elements. The largely steel kitchen displayed this through the use of free standing units, abundance of industrial steel, and use of bright coloured paint in both the kitchen and bathroom areas. The Hannah's Warehouse larger apartments had the most versatile and unique kitchens, including a customised steel mesh unit that enabled the oven area to be closed off. The shelves were fully exposed, and it was an important decision on the part of the original resident (also the designer) not to have any cupboard doors, but to have everything out in the open.

As opposed to the Odlin's and Shed 21 kitchen and bathroom spaces, the amount of freedom and experimentation in the Hannah Factory and Warehouse kitchens was largely due inhabitant being able to have a choice in the final outcome. This was evident in the prospectus for potential buyers, which stated the areas where clients had a choice to make 
changes or spaces would be configured after the purchase. ${ }^{11}$ The same could be said for the three other larger apartments within the Hannah Warehouse, for they were all privately occupied by the building's new owners and investors. The Hannah Warehouse's larger apartment used free standing furniture to create space divisions. Custom-built book shelves were used as partitions, and the kitchen had free standing shelves in place of walls to separate it from the living and dining area.

Curtains were not common among the four case studies. Shed 21 used bi-folding wooden shutters, which shielded light and segregated the bedroom areas from the overlooking lounge and dining areas below, creating privacy when required. The owners of the Hannah Warehouse's larger apartments were adamant about not having any curtains. The smaller apartments in all case studies, excluding Odlin's, had curtains inserted as the residents chose. No curtains were present in the apartment visited in the Odlin's Building, as it was on the top level with no adjacent buildings and a balcony that shielded the internal spaces for privacy.

\section{Design Approaches and Aesthetic}

The Odlin's Building received the greatest modification, particularly internally and to the seaward facade, where the new punctured colonnade and altered windows were most visible. The shape of the windows was altered by modifying them from smaller semi circular arched windows into larger square aluminium framed ones. Modification of windows was most obvious in the Odlin's Building, as the seaward and street side facades do not match, and the introduced rectangularity is a new architectural language, foreign to the building's existing window characteristics. The differentiation between old and new is clearly visible. The existing steel windows in the Hannah Factory were refurbished, while the damaged windows were replaced with powder coated aluminium, as well as new steel framed windows being inserted at ground level. A new steel framed balcony system was installed at the west end with new double height steel framed bay windows to the south side. Shed 21 retained its existing full height ecclesiastical semi arched windows, as this aspect was a significant feature of the building, and allowed enough light to infiltrate the interior. Damaged windows were repaired to match existing. The Hannah warehouse kept its original window frames but replaced damaged glass with single panes of glass.

The interior design in the waterfront apartments differed to that of the Hannah's Leeds Street warehouse. This was especially evident in the carpeted floors in both of the waterfront buildings and exposed original flooring with

11 Hannah Warehouse Prospectus, 13 Leeds Street Te Aro Wellington. 1999. Source Victoria Quade, Athfield Architects,. Hannah Apartments Prospectus. Wellington. 1996. existing marks made by former factory and warehouse workers in most Leeds Street warehouse and factory apartments. The Hannah Warehouse had wool carpet fitted in areas requiring impact sound reduction rating, such as hallways and office spaces. ${ }^{12}$ Even in the later New York conversions, fully carpeted areas were less common, as the original floor was left exposed and rugs were used for comfort or to separate spaces. As mentioned later in this discussion, noise levels and codes were raised after the early Hannah conversions, and unlike the New York lofts, the relevant Building Code had to

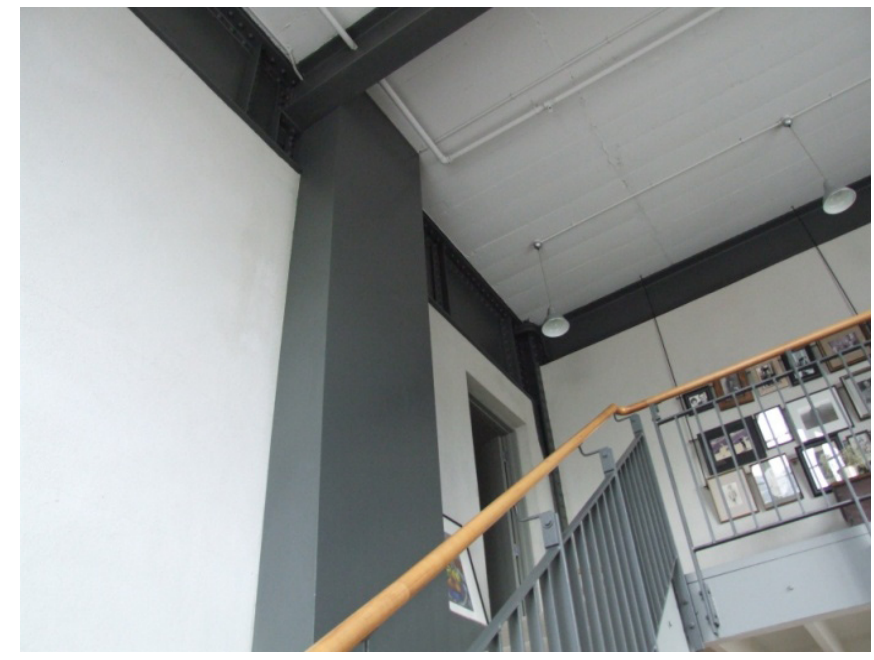

Fig 85. Exposed structural elements in Shed 21 apartments

be followed in New Zealand. The notion that noise came with inner city living was still something New Zealander's could not comprehend and accept easily. ${ }^{13}$

The additional earthquake strengthening that was also a Building Code requirement acted as a design element in all four case studies. It was least prevalent in Odlin's, which was predominantly reconstructed from scratch, so there was limited existing material that could be left exposed. In both of the Hannah's buildings, the additional strengthening worked alongside the existing industrial aesthetic, highlighting the original industrial manufacturing nature of the building as the steel bracing was left exposed, running along the walls and the underside of the ceilings.

The Hannah Factory went as far as revealing all the piping and ducting in the apartments, almost like a decorative element, functional yet unconcealed. However, as one resident stated, this was the greatest cause of sound transfer, as the piping was connected between each apartment. The common areas also followed the exposed industrial aesthetic and were stated in the prospectus to provide a subdued entry

12 Hannah Warehouse Prospectus, 13 Leeds Street Te Aro Wellington. 1999. Source Victoria Quade

13 Athfield. Z., and Hardwick-Smith J., Personal Interview., 11 November 2011 
into the apartments. ${ }^{14}$ The overall aesthetic of the Hannah Factory was one that although designed by architects, had the essence of being raw and unfinished, making it an amalgamation of the existing industrial factory and the new additions.

One aspect that was common in three of the four case studies was the treatment of the timber ceilings. Each apartment had the timber ceilings painted a shade of white. This allowed for the spaces to appear brighter, especially in the apartments where there was minimal penetration of natural light. The light colour finish also emphasised the steel attached to the ceilings. It also provided a neutral background to allow the brick and dark wood to stand out, giving relief from the otherwise darker elements. The Odlin's apartment was the only one that had an unpainted timber ceiling, but this was because the timber ceiling was the most significant historic element in an otherwise newly constructed interior space.

Another commonality among the apartments in the four converted warehouse and factory buildings was the minimalist approach to finishes applied to new walls. Where walls were painted, the colours were kept neutral and light, mostly using shades of white. This could have been done not to detract from the bright brick and exposed steel strengthening, or to bring a sense of light into the darker apartments. White washing the brick was predominantly avoided. Any steel that was painted used a grey metallic paint This was both an intumescent fire protection and retained the original look of the steel.

\section{Structural Upgrade}

Reinforced concrete block work was used for shear walls in Shed 21, and the Hannah Factory. Again, these inserted walls were left exposed in the Hannah Factory but in Shed 21 were covered up and plastered with plaster board, due to the different design approaches taken in converting the warehouses. The seismic code has changed since the buildings were designed, and now they are unlikely to be 100 percent compliant. At its conversion, Shed 21 was strengthened to 70 percent of the Building Code, with a ten year compliance upon the building's conversion and reuse. ${ }^{15}$

Because all four cases studies were brick shell structures, these had to be strengthened. Each building used a different method to do this. As well as the steel rods that secured the external walls in the Hannah Warehouse, both the Hannah's buildings used steel cross bracing to the interior of the brick walls, as well as to the underside of floors. Odlin's Building was substantially strengthened to approximately 110 percent

14 Athfield Architects,. Hannah Apartments Prospectus. Wellington. 1996. 15 Annette Wale, Apartment 2.0, Waterloo on Quay Apartments, email.

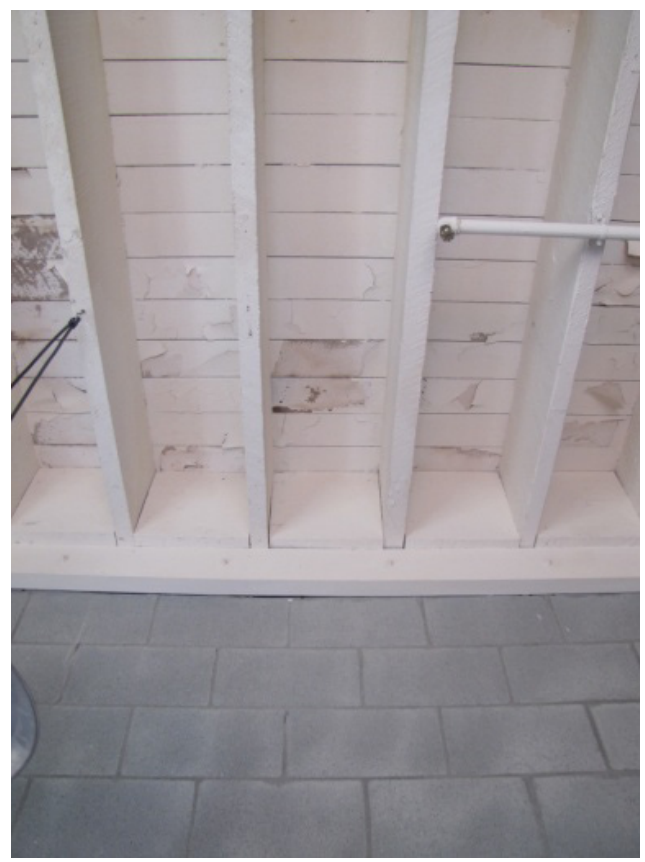

Fig 86. White paint applied to ceilings, seen in three of the four case studies. Note the ceiling joists are left exposed, this as prevalent in all four case studies to some degree. Refer to Odlin's Building where part of the ceiling was covered up with down lights inserted.

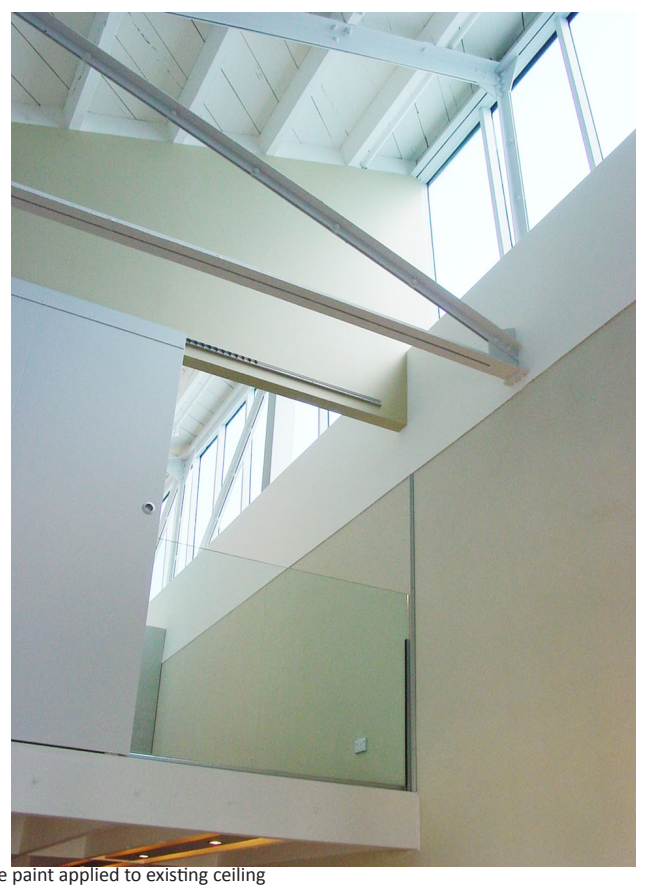

of the Building Code, current at the time of its conversion ${ }^{16}$, making it one of the most structurally viable of the converted buildings in 2011 .

The developers of the Odlin's Building, Willis Bond \& Co., tried to future proof and insure the building for the next 10 
years following its conversion. Primarily, this was because so much of the building had to be rebuilt due to rot from the water damage, meaning the interior within the shell had to be constructed from scratch. The small amount of existing fabric left visible at the top apartment level was primarily located in the ceilings' old and new exposed beams spanning their underside. The rafters and their connections were also heritage items and were preserved and left exposed in the loft spaces of the apartments, providing some link with the original building framework. Whereas the Hannah Factory and warehouse were strengthened through a steel framework, shear walls and cross bracing. The Odlin's Building was largely strengthened through its moment resisting frame (refer to the digital modelling images in Chapter Two). This provided a complete space frame throughout the building which could carry the vertical loads and resist lateral forces.

Some floors were thickened by having a concrete overlay applied over the top. This happened in all of the case studies apart from Shed 21, which already had thick enough reinforced concrete slab floors. The concrete floor that was set over the existing timber floors on two levels within the Hannah Factory helped to seismically strengthen the building, however it was an interesting choice on the part of Athfield Architects to cover up an existing material, as opposed to exposing it. The architects stated this could have been the cheaper option at the time. ${ }^{17}$

A structural assessment carried out on the Hannah Warehouse in 2007 concluded the building complied to $47 \%$ of the current regulations at the time of the assessment. ${ }^{18}$ Effectively each of the conversions were done at different times and were strengthened to a degree of compliance with the then current building Code.

An excerpt from a letter dated 27 November, 2007 by Dunning Thornton regarding the strengthening and compliance of buildings with the Earthquake Code stated:

\begin{abstract}
The building regulations governing the performance of buildings in earthquakes have recently changed. In the past there was a sliding scale meaning that buildings of different constructions and ages were required to comply with different standards to different extents. The recent change in regulations has been to require all buildings to have a $33 \%$ compliance with the current design standards... buildings are required to be one third as strong as a new building of the same sort. ${ }^{19}$
\end{abstract}

More recently the Wellington City Council Published a list of residential and commercial buildings identified as being

\begin{tabular}{l}
\hline 17 \\
$18 \quad$ ibid \\
Building at "Hannah Warehouse" at 13 Leeds St, 28 November, 2007, letter \\
$19 \quad$ ibid
\end{tabular}

Earthquake Prone. The buildings listed in this thesis were omitted from the list, however, there are still ongoing inspections. ${ }^{20}$

The most interesting and successful strengthening methods employed were the ones where the new additional fabric worked alongside the original. This makes a clear differentiation between the old and new, respecting the building's history, yet also integrating well with the theme and original function of the building.

\section{$\underline{\text { Fire Protection }}$}

Athfield Architects stated the size of apartments was determined by a combination of factors and that it was important to try and use the existing structure and what was already there to start with. In the Hannah Factory and Shed 21 , structural block work was used for its fire, acoustic and strengthening properties. ${ }^{21}$ Because the expected return rate was also much higher, the waterfront conversions had to be readily insurable.

The Odlin's Building, which was largely rebuilt internally, used concrete floors and concrete reinforced steel columns to separate the building into multiple fire cells. All the converted buildings used fire rated walls that faced the corridor.

A common advantage shared by all four factory and warehouse buildings, was their large existing windows, and their segregation from other nearby buildings. All four existing buildings were stand alone structures, not adjoining any other building, which allowed light to penetrate from all four directions. This is another ideal characteristic of existing warehouse and factory buildings which makes them prime candidates for residential conversions. Few additional windows had to be inserted or existing ones amended in all of the converted buildings, although several of the cases studies had skylights inserted into the loft apartments. Shed 21 had an existing glass roof gallery space, which emitted extra light into the corridor areas on the apartment level.

\section{Parking}

The number of car parks required for inner city apartments per dwelling was one, as of November 2011, but suggestions have been made that this requirement may decrease. ${ }^{22}$

The reason the car parks were omitted in the Hannah Factory, was the developer realised the apartments would sell even without the provision of a car park space. ${ }^{23}$ The Wellington City Council stated the reason for the Hannah

\begin{tabular}{ll}
\hline 20 & "Earthquake-prone Buildings Policy", Wellington City Council. http:// \\
www.wellington.govt.nz/services/earthquake/policy.html 7.2.2012 \\
21 & ibid \\
22 & Athfield. Z., and Hardwick-Smith J., Personal Interview., 11 November \\
2011 & ibid
\end{tabular}


factory not having to provide parking for residents was because,

\begin{abstract}
The Hannah Building is zoned Central Area and is not Inner Residential. There is no requirement for parking in the Central area (rule 13.1.1.7.1), only a provision for a loading bay (rule 13.1.1.7.6). Council lets the 'Market' lead the demand for parking and thereby through a space and cost detriment the citizens are persuaded to walk or use public transport $(12.2 .8 .3)^{24}$
\end{abstract}

The other three cases studies have at least one car park per resident. Shed 21, Odlin's Building and Hannah Warehouse were each provided with inside car park spaces at ground level with private security access, as well as having parking spaces outdoors.

Comparison-Lofts in SoHo, New York and Wellington, New Zealand

There are several architectural differences in the Wellington lofts compared to the original pioneering and current lofts in New York. In New Zealand the residential loft market is still relatively immature ${ }^{25}$ compared to a highly developed and accepted one in New York. The idea of uncarpeted floors of bare timber or concrete is still not easily accepted in Wellington, because the current generation of apartment dwellers expect an inner city apartment to resemble a suburban house. According to Athfield Architects sound transmission requirements were partly heightened due to residents complaining about inter tenancy noise levels. The Building Code reacted, and sound transmission requirements were raised. ${ }^{26}$ Developers would also get advice from the real estate market on what was selling and what was not, and the architects would have to consider this. Athfield Architects feel that for future generations, apartment living will improve, and people will begin to understand and appreciate, as well as accept the conditions that come with inner city living. ${ }^{27}$

The exposed kitchen and freestanding furniture in some of the larger converted buildings of Wellington share similarities with traditional SoHo lofts of New York. .This exposure creates a sense of clutter, not by being messy, but simply due to everything being on display as opposed to hidden behind doors. This is similar to the early SoHo loft aesthetic, where there were no storage spaces or built in cupboards, so everything was exposed and on display. Even after the installation of piping and essential appliances, kitchens in 24 Simmons, R., Planning Technician Local Area Planning Team Development, Planning \& Compliance Wellington City Council. email. 16.11.11

25 ibid

26 Athfield. Z., and Hardwick-Smith J., Personal Interview., 11 November

2011

27 ibid the early SoHo lofts were still a product of the residents' personal preference. They were often open plan and part of the dining area and had interesting decorative elements. One artist furnished his kitchen with a number of industrial parts found in the neighbourhood. An old wheel, suspended from the ceiling was converted into a pot rack. ${ }^{28}$ In terms of floor to ceiling heights, in a converted SoHo apartment the ceilings were usually between 12 and 15 feet $^{29}(3,700-4,600$ millimetres), and the Wellington case studies had similar initial floor to ceiling heights, albeit most had a mezzanine inserted to fit a bedroom level into the double height space.

Later SoHo lofts from the mid nineties onwards share more similarity with the converted examples in Wellington. This happened as a different demographic began to move in, primarily wanting the converted warehouses for residential spaces rather than for making artworks.

Exposed brick and concrete floors may not have appealed to the general public and the apartments had to be sold as complete and finished living spaces. The artists of SoHo, illegally squatting in the lofts, only had themselves to please, and therefore they had complete freedom in how they would decorate and furnish their space. Everything was impermanent, and had to be easily concealed or hidden.

Around the 1970s, as the bare polished
wood floors, exposed red brick walls, and
cast iron facades of these "artists quarters"
gained increasing public notice, the economic
and aesthetic virtues of "loft living" were
transformed into bourgeois chic. In large
numbers, middle-class and upper-middle-class
residents began moving into lofts, too.

In terms of urban gentrification, some parallels can be seen between Wellington and New York. In SoHo, areas which had been uninhabited and unpopulated became thriving communities and new neighbourhoods. Areas in Wellington that had previously been closed off and considered unsafe (Hannah Buildings), or abandoned and unused (Shed 21, Odlin's), were also turned into inhabited areas. These latter two buildings were part of the rejuvenation of the Wellington waterfront, but it cannot be said that the rejuvenation of this area occurred primarily because of their redevelopment and conversion.

The residents that did eventually move into the four warehouse and factory buildings in Wellington, were primarily middle or upper class, singles, young professionals, older couples without children and in some cases a few families. ${ }^{31}$ For some this experimental way of living was new

\begin{tabular}{ll}
\hline 28 & Slesin, S. The Book of Lofts., 76 \\
29 & Zukin, S. Loft living : culture and capital in urban change., 2 \\
30 & Zukin, S. Loft living : culture and capital in urban change. 2 \\
31 & Nichol, R. "The Tidy Ones". Evening Post. Wed July 11. 2011
\end{tabular}


and exciting. Living in the inner city as opposed to the suburbs was appealing for the younger demographic, while the older buyers, predominantly in the waterfront conversions saw this as good investment opportunities, and no longer had children to support, nor gardens to maintain.

What was most evident among the Wellington conversions, was that the idea of living in a warehouse, although little resembling the pioneering loft idea of living, was fashionable. This could be seen in the prospectus' that advertised converted lofts as "New York Style Lofts". The term loft-living was and is still employed widely.

\begin{abstract}
Although the original ideal of loft livingmaximum space at minimum cost-has often been compromised by developers in recent years, the principal of having the freedom to make your home whatever you want it to be still makes the concept highly seductive. ${ }^{32}$
\end{abstract}

\begin{abstract}
A loft, in the original sense of the word, deriving from the United States, simply means an upper storey of a warehouse or factory. More specifically, the word now conjures up an image of a converted open-plan space in which the original structure is juxtaposed with new architectural insertions and evidence of domestic use. ${ }^{33}$
\end{abstract}

SoHo buildings particularly suffered in the climate of the economic expansion of the 1960s, following technological change and advancement. These former industrial warehouses lost their original purposes. In Wellington, the four chosen warehouses and factory buildings also became obsolete due to containerisation, and loss of use, but they tended to stay vacant for much shorter periods. They also did not go through the gentrification process of the New York loft living phenomenon. If there were squatters in Wellington, they were not artists and did not inhabit these spaces for the same purpose as in New York. Traditional lofts would often have the bathroom as the only room that was enclosed within the apartment, although some residents omitted doors even from this space. ${ }^{34}$

All four Wellington case studies had the bathroom spaces sectioned off in at least some way, although the Hannah Factory's largest apartment was most like a true loft, with one floor completely free of walls and doors, apart from the bathroom. When gentrification occurred in SoHo, the lofts were customised to the inhabitants' preferences and this often included making separate bathrooms and inserting more partitions throughout the entire space.

The division of the loft was the first step in its

\begin{tabular}{ll}
\hline 32 & Field, M., and M Irving. Lofts.5, \\
33 & ibid.137 \\
34 & Slesin, S. The Book of Lofts., 100
\end{tabular}

gentrification. Loft dwellers-both the pioneers and the new residents-have become older and more settled, and the former industrial spaces are increasingly dived up into living places that have to function for a group of people rather than for a single occupant. The luxury of open, uninterrupted space has given way to more practical considerations of everyday family life...while dividing the loft meant a loss of openness, it also represented an important step in the design evolution of these chameleon like living places. ${ }^{35}$

In SoHo, New York, after the notion of loft-living became popular and was no longer solely confined to artists, the middle and upper classes became interested in purchasing these spaces. The government praised loft living and associated it with the general urban regeneration of the 1970s. The residential conversion of lofts thus began to interest sponsors of a different kind,

\begin{abstract}
Due to the popularity of loft living, property developers, investors, and real estate developers became interested as opposed to tenants and owner-occupiers. "Because of their priorities, the nature of the conversion process, as well as the character of the spaces that were converted changed. Residential conversions attracted more professional types of developers. ${ }^{36}$
\end{abstract}

\section{Conclusion}

One thing all four case study buildings shared was that their conversion involved the implementation of a new programme that allowed these buildings to continue to stand, as opposed to being demolished. Because of their strong existing structure and qualities of age and history, and the open plan and high walls, the buildings were good candidates for accepting a new programme and undergoing internal modifications. Their historic nature and past was however, also preserved, although in some more than others.

...introducing new life into an old building is in many ways like translation, the carrying over of the host building from one age to another...the carrying across of a building from one age to another, from the past to the present. ${ }^{37}$ 


\section{Recommendations for Future Conversions}

All four case studies demonstrate a varied approach to the conversion process, both in regard to their structural upgrade and aesthetics, however the idea of revealing, both in terms of architectural and structural elements and the existing historic programme is prevalent to various degrees among all the Wellington conversion examples. The idea of exposing existing spaces, materials and architectural elements is something that pertains to the loft aesthetic portrayed and exemplified in the pioneering early lofts of SoHo, New York, and ones that have established the preconceived aesthetic of a converted warehouse or factory space.

The conversions cases in this thesis that most demonstrated and complied to the loft aesthetic in terms of their conversion, were those that tried to preserve as much of the existing fabric, structure and thereby history as possible. The buildings original manufacturing nature could still be seen through elements and traces, although reused to serve a completely different programme. Keeping the dramatic floor to ceiling heights where possible, will allow for the space to feel both spacious and sheltered from the external noise and activity, whilst accommodating the requirements of the residents. If a bedroom has to be inserted a semi exposed mezzanine level can be created. Building into the roof is also a good way to create an extra level as this allows for the roofs true loft area to be utilised and a chance to reveal existing fabric such as the trusses and joist beams.

Another way to create spaciousness is to avoid inserting partition walls. If this is inevitable, it is beneficial to avoid fixed walls that span full lengths and look to other ways of shutting off or opening spaces if privacy is a absolute requirement. This can be done creatively by using freestanding furniture that can be moved around, employing full height book shelves, concertina or bifolding doors, and storage units, as opposed to inserting permanent partition walls. This in turn will allow for a harmonious open plan living space, without restricted designated rooms that can be arranged and rearranged accordingly.

The pioneering lofts in New York were infamous and revolutionary for their bare aesthetic and minimal intervention. Early loft dwellers tried to impose as little intervention as was possible. It is vital to research what the building and its different parts was used for, i.e where the original entrances were and what their specific functions were as well as what the internal elements were used for. Along with a structural assessment this will enable an understanding of the most historically significant parts and areas of the building which are to be retained, repaired or maintained.

Floors and walls are ideally to be retained in their existing state, providing the existing structure complies with the current Building Code. Adhering to sound regulations and acoustics will need to be assessed by engineers and comply with legal requirements, however the way this is achieved can be creative and less intrusive than one thinks. The way in which the Hannah's Factory building was converted is a good example of a successful modern intervention. It employed reinforced concrete block for structural purposes, noise control and fire protection. Typical lined partition walls also had extra $75 \mathrm{~mm}$ fibre glass batts layer for sound insulation, as well as being fire rated. The choice of this material is thus, one that is a modern intervention that works well alongside the existing, and allows to read as exposed and "raw". Replacing windows panes for double glazed ones can be effective for both sound insulation, especially from external noise and to preserve more heat.

Where possible, full height ceilings should be retained. Rather than creating a false ceiling to incorporate services and air conditioning, the ceiling heights can be retained by leaving the piping and necessary wiring etc exposed. The same can be done with the lighting; instead of inserting inbuilt lights into the ceilings, lamps and hanging bulbs can provide sufficient light. Where possible the introduction of new materials should be consistent with the existing, or on the other hand a complete contrast, to allow for differentiation between the existing and new.

Structural upgrade is crucial to allow for residential habitation particularly in cases where the owner was a property developer or the building was part of the Wellington city Council reuse plan. Because warehouse and factory buildings have an existing industrial nature due to their use, the structural upgrade can and should act alongside this industrial aesthetic. Exposed steel strengthening in the form of cross bracing, $\mathrm{K}$ frames etc to walls and to the underside of floors or ceilings is interesting aesthetically as well as a possible structural solution. Each building should however be structurally strengthened in compliance with the most current New Zealand Building Code. Strengthening a building against earthquake forces is imminent.

If the building is brick, aesthetically cross bracing as the more favourable way of strengthening the perimeter internal walls as opposed to adding an inner layer of structural material, as it maintains the existing material and patina brick surface. Inserting a concrete band around the perimeter or steel channels is another option, as well as inserting steel rods and plates right through the brick wall. Plastering over existing walls and covering up original materials ruins the raw industrial feel of a true loft and makes the conversion resemble a modern apartment as opposed to a unique warehouse or factory space. Existing columns, commonly consisting of reinforced concrete, steel, timber or even cast 
iron should also be left in their original sate if structurally compliant, without being plastered or gibbed over. The existing, aged material in warehouses and factories is the interior decoration in itself. This is what makes the loft look unique. There are often valuable hardwoods and other materials inside these spaces that should be displayed and left uncovered by carpet or additional linings.

Also, avoid painting over the existing bricks or concrete. Where intumescent paint is required to steel etc, use a colour that most resembles the original materials hue. Where a space is dark and devoid of much natural light, existing timber in areas like trusses can be painted a white colour, this will work well alongside the existing red tinted brick, providing relief. Extra light can be introduced through the placement of skylights in the upper roof area.

Where possible, floors can also be left exposed. These are commonly concrete or timber. If the concrete is thick enough it may not be necessary to add a carpet over the top to prevent sound transmission, however, acoustic protection in the form of batts or suspended ceilings can be applied to the ceiling as opposed to the floors to maintain the existing floor material. A coating of resin is another option for concrete floors. It gives good impact thermal shock resistance and the compressive strength as well as the ability to dissipate stress and increase the load bearing limit of the concrete underneath $^{1}$, as well as giving a nice quality finish.

Restoration of significant materials and spaces is crucial. This could entail, polishing back floors and walls repairing window mullions and replacing glass. Where possible materials that are damaged and need to be replaced should match the existing. Part of the charm of living in a converted warehouse or factory is being able to still see what the building was once used for. This could be implemented in the retention of pulleys and steel beams, loading bays and lifts, as well as retaining entrance ways based upon their specific functions.

Furniture, joinery and fixings should work alongside the warehouse or factories existing materials. If the building is mainly concrete and steel, the introduction of a plastic as a material for cabinetry seems out of place with the overall look and atmosphere of the existing space and rough surfaces. The benefit of an open space warehouse or factory space is the freedom the tenant has to segregate and create areas through the use of furniture and decorative items, based upon their personal preferences. The industrial aesthetic in the form of stainless steel, brushed aluminium on sinks, appliances, accents on furniture and kitchen accessories and exposed cabinetry could extend to the kitchen and bathroom.

$1 \quad$ Resintek Services Limited. Web. 11.01.12
An introduction of softer materials like rugs and other furniture can however transform the place and act as a juxtaposition to soft versus hard surfaces, creating the sense of comfort and residential space. The idea of cupboards and inbuilt closets was not prevalent in the lofts. Belongings, object were out in the open. Kitchen joinery should minimise doors and cupboards, instead using shelves for storage. These shelves can alternatively also be used to act as free standing space divisions, separating the kitchen form the dining area. Custom built furniture is ideal as it can bring a sense of scale to the open plan spaces, and have dual purposes.

One of the appeals of warehouses and factories is their expansive windows. To maintain a true loft aesthetic, window coverings such as curtains should be avoided if possible. If the requirement for privacy or shielding from the light is needed, bifolding wooden blinds, bamboo blinds, tailored Roman blinds or screens is a diverse and applicable way of going about this. To keep as much heat in as possible drapes could be employed at time, as the brick or concrete frame structure does not provide as much thermal heat.

The fusion of old and new intervention should create a rich narrative without losing the essence and warehouse and factory aesthetic of the buildings original character and use. The new material should age accordingly, gaining their own patina of age.

One of the most unique attributes of a converted warehouse or factory space is that the building has been reused for an entirely new programme and purpose to its original intended one. A building that was not intended for residential habitation, and one that housed dozens of workers becomes a home for a family or less. The crucial thing to keep in mind when converting such a building is the history it possesses is what makes it unique and interesting to work with. Choosing to live in a loft, shows respect and concern for the city's past and its preservation, as well as its future. Traces of its former use should remain to some extent. As sated in re-readings by Graeme Brooker and Sally Stone,

Buildings are remodelled, reused, rethought and yet a suggestion of the former meaning disturbs and inspired the subsequent design. ${ }^{2}$

The Loft aesthetic is one where there is a juxtaposition between industrial raw, nature mixed with modern minimal intervention.

$\overline{2}$ Brooker, G. S, Stone, Re-Readings. 19 


\section{Conclusion}

The aim of this thesis was to investigate existing warehouse and factory apartment conversions in Wellington, and thereby, formulate a methodology and architectural strategies for structuring future conversions of warehouse and factory buildings into residential apartments. This was achieved through the detailed analysis of four buildings that had previously existed as warehouse and factory spaces, but that had been converted into residential apartments. The analysis of these four case studies showed four alternative approaches to convert warehouses and factories, thus highlighting the differences and similarities of conversion.

The thesis first investigated the early recorded lofts- turnedresidential spaces in SoHo, New York, where loft living was first established and documented. This section illustrated that it was in SoHo that this movement began. From there it spread globally, both as a cultural movement as well as an architectural and design one. The four buildings analysed in the thesis display some parallels to the loft-living ideas established in New York.

The conversion process of each Wellington case study was analysed based on a structured set of criteria. Each analysis considered the building's historical importance and impact on Wellington prior to the conversion and after, who the owners and developers were, and whether this affected the overall outcome of the conversion. This thesis also analysed the existing structure of each building and what methods were required and used to successfully structurally upgrade the building for residential use. It also analysed the design of new alterations to the existing building.

Discrepancies in conversion approaches between the waterfront warehouses and the factory buildings were found. The former Shed 21 and Odlin's Timber \& Hardware Co., located on the Wellington waterfront, both had a Category 1 Historic Listing, and were part of a greater scheme to redevelop the entire waterfront, therefore there was more economic pressure for them to be successful redevelopments. These conversions had a lot of political and public pressure, as well as having to comply with a strict framework set out by the council, outlined for the redevelopment of the waterfront area. The developers who were involved with their conversions also had an ideal aesthetic for the apartments in order to sell them to a certain demographic of clients. The potential buyers of the waterfront apartments also had expectations and preconceived ideas of the kind of apartment they would buy, based on the particular developers associated with the conversion and the type of work for which they were renowned.

There was pressure on the architects to abide by the Historic Places Trust criteria, work within the Waterfront Framework, and create apartments in accordance with the developers' vision.

The conversion of the urban inner city Hannah's Factory and Hannah Warehouse varied greatly from those on the waterfront. This was largely due to the developers' vision, which was a more experimental and raw approach, raw in the sense that the final design had the look of being unfinished. This was attributed to the exposed and unconcealed elements. These apartment were advertised to a different demographic who were generally younger, more urban, and willing to live in alternative apartments. These residents were also interested in living and working at home. The lack of a Historic Places Trust registration meant there were less constrictions on modifying the buildings. Because the Hannah Warehouse was bought by private investors, the building belonged to private owners as opposed to the Wellington City Council. These buildings also had the most historic features retained, and new additions which worked well with the old.

The Hannah Factory was Wellington's first recorded converted warehouse apartment building. The warehouse living phenomenon did not emerge until the 1990s in Wellington. Inner city living was still much less common than living in the suburbs. Because a market for converted warehouse apartments was still emerging, the first experimental examples such as the Hannah Warehouse and Factory had less pressure to succeed economically and were not marketed to high end owners. The architects had freedom to test out new ideas, and not be compromised by the developer. Because Leeds Street, the location of the Hannah factory and Warehouse, was harder to access in a dead end side street with very little public activity, there was less reason for the public to oppose this rejuvenation. In the end the redevelopment of the former industrial derelict area into residential apartments, not only benefited and preserved the building and its history but regenerated the entire area by bringing people in using a new pedestrian thoroughfare. This thesis demonstrated that the Hannah's Factory and Warehouse were the most similar to the early conversions that happened in SoHo, New York. The conversion of the Leeds Street buildings help rejuvenate an entire block and neighbourhood, bringing people and activity into an area that had once been considered unsafe and inaccessible. This is similar to the rejuvenation and gentrification that occurred in SoHo.

The biggest difference between loft living in Wellington, New Zealand and SoHo, New York, was that the cultural phenomenon of loft living that occurred in SoHo never occurred in Wellington. New York based artists illegally occupied large lofts in illegally zoned areas, using the buildings' large scale dimensions and open plan spaces for 
both working and living. Because the loft living movement spread and gained popularity, the interest in living in these lofts resulted in zoning changes, which allowed people to legally live in a previously manufacturing industrial area. When the lofts' landlords realised there was revenue to be made from these converted warehouses, the prices went up and the middle class moved in. The aesthetic of the lofts began to change to accommodate the needs of residential living and the new demographic, allowing for comfort and luxury. Thus, the loft living movement in SoHo went through several changes, both in terms of the people that lived there and the loft look as a result of the type of resident.

In Wellington, loft living occurred much later when it had already emerged globally as a marketable and fashionable phenomenon, aimed at the middle and upper classes. In most cases it was a product of real estate developers, who used the word 'loft living' as a term to sell an image of a New York loft. These so called "New York style lofts" did not necessarily resemble the legitimate early artists' loft, but were conversions based on what would be profitable in the property market and ultimately sell. The space was sold entirely finished, rather than one created by the resident.

\begin{abstract}
A loft, in the original sense of the word, deriving from the United States, simply means an upper storey of a warehouse or factory. More specifically, the word now conjures up an image of a converted open-plan space in which the original structure is juxtaposed with new architectural insertions and evidence of domestic use. ${ }^{1}$
\end{abstract}

The lofts that began to emerge after they were no longer purely occupied by artists have more in common with the converted warehouses and factories found in Wellington, New Zealand. In all four case studies the large-scale dimensions and expansive spaces were retained, the level of existing material was also found but the amount differed among the different buildings.

Although the converted Wellington examples of factory and warehouse buildings may not possess the same experimental and raw unfinished loft aesthetic of the first lofts, there was still a clear retention of the buildings' former uses.

The most successful conversions were those that demonstrate a firm understanding of the original building combined with the remodelling. The existing conditions of the building, the context, site, original programme, structure and spaces are used as the inspiration for the redesign.

Each building's original frame work was never compromised to conceal its nature but rather its former use and elements of its history and heritage were highlighted by the conversion. $1 \quad$ Field, M., and M Irving. Lofts.137
The conversions shown in the thesis also demonstrate that by successfully converting the buildings and instilling new programmes into them, each building was essentially given a second life. This shows that only upon conversion have the buildings gained a sense that each has achieved its true destiny. 


\section{Bibliography}

Absolutely Positively Wellington. The Wellington Waterfront Framework Report of the Waterfront Leadership Group. Pub lished by Wellington City Council, Wellington. N.Z: 2001. 29 Mar 2011. <http://www.wellingtonwaterfront.co.nz/docs/framework.pdf>

Anderson, Brent, Resident 15 F Cable Street, Odlins Apartments. Message to the author. 28 .11.11. email

Anderson, Brent, Resident 15 F Cable Street, Odlins Apartments, Personal Interview, 25 June 2011

Applied Technology Council. Built to Resist Earthquakes. Web. 20.8.11. <http://www.atcouncil.org/pdfs/bp1c.pdf>

Aranguiz., Antonion Corcuera. City Interiors. Singapore: Page One Publishing, 2005.

Architects, Athfield. Hannah Apartments Prospectus. Wellington. 1996.

Athfield Architects. Hannahs Factory. Wellington. C 1998. CD

Athfield Architects. Odlins Building. Wellington. C 2005. CD

Athfield Architects. Waterloo on Quay Apartments (Shed 21). Wellington. C 2002. CD

Athfield. Z. and Hardwick-Smith J. Personal Interview. 11 November 2011

Attwell, Peter. "A House of Four Lives". New Zealand Historic Places. No 36 March 1992. 9

Berens, Carol, Redeveloping Industrial Sites: A Guide for Architects, Planners and Developers. Hoboken, N.J.: John Wiley \& Sons. 2011.

Brookes, Barbara. At Home in New Zealand: Houses, History, People. Wellington: Bridget Williams Books. 2000.

Buchanan, D., Chair Wellington Civic Trust. Submission to: Waterfront Development Sub-Committee Proposed Refurbishment of the Odlins Building: Wellington Waterfront. 7 October 2003. 16.7.11 http://www.wellingtoncivictrust.org/wp-content/uploads/2008/05/2003 1007 odinsbuilding.pdf

Burnham, Clint. Postmodernism Is the Theory, Gentrification Is the Practice: Jameson, Haraldsson, Architecture, and Vancouver. <http://woodsquat.files.wordpress.com/2010/01/burnham-postmodernism-is-the-theory-20042.pdf.>

Cassels, Ian. Personal Interview. 12 May, 2011

Charleson, Andrew. Seismic Design for Architects. Oxford. Architectural, 2008.

Charleson, Andrew and Mark Taylor. Towards an Earthquake Architecture. <http://www.curee.org/architecture/docs/towards-a-_seismic-ar-2CDB8.pdf.>

"Chic City pads for the well-heeled". Evening Post. August 13 1997. Alexander Turnbull Library

Christeller, Fiona., “Wellington's Waterfront Saga”, Planning Quarterly. December 1989. No 96. 6-8

Cole, D. "Artists and Urban Development", The Geographical Review, October 1987. Vol 77. No 4.

Dave Pearson Architects Ltd., Shed 21 Assessment of Effects. Auckland: Newcrest Holdings Ltd, 2000.

Diamonstein, Barbaralee. Remaking America: New Uses, Old Places. New York: Crown, c1986., 1986.

Don Thompson Consulting Engineers., Re: Potentially Earthquake Prone Building at "Hannah Warehouse" at 13 Leeds St, 28 Nov, 2007, letter

DuluxAcratex. Odlins Building.1 Aug. 2011. http://www.duluxacratex.co.nz/odlins-building

Dunning Thornton Consultants Ltd. Odlin's refurbishment: Existing Structure and Construction Hazards. Wellington City Council. 15 August 2003 
Dunning Thornton Consultants Ltd, Specifications. Waterloo on Quay Seismic Strengthening and Redevelopment of Shed 21 for Shed 21 Ltd Stage Two Contract., August 2001. CD

Emma O'Kelly and Corinna Dean., Conversions, London: Laurence King, 2007.

The End of Suburbia-Oil Depletion and the Collapse of the American Dream. Dir Barry Silverthorn, Toronto: Videocassette, The Electric Wallpaper Co, 2004. Film

The Factories: Conversations for Urban Culture. London: Basel: Birkhauser; London: Momenta. 2002.

"factory, n.". OED Online. December 2011. Oxford University Press. 15 January 2012 <http://www.oed.com/viewdictionaryentry/Entry/67525>.

Field, Marcus., Irving, Mark. Lofts. Corte Madera, CA, USA: Gingko Press, 1999.

Form and Function. 8 Oct ober 2009. Web. 8 Apr 2011. <http://16freckles.wordpress.com/2009/10/08/design/\#>.

Former Hannah Footwear, Wellington City Council. 4 October 2011, <http://wellington.govt.nz/services/heritage/details. php?id=266\&m=search>

Footwear and Leather Goods."The New Zealand Railways magazine.1940 Volume 14 . No10 15.3.2010 <http://www.nzetc.org/tm/scholarly/tei-Gov14_10Rail-t1-body-d6.html>

Franklin, Bridget., Housing Transformations: Shaping the Space of 21st Century Living. New York: Routledge, 2006.

Gaitanos, Sarah., "Let there be Light". Urbis. Spring. 1999, 52

Garvin, Alexander., The American City: What Works, What Doesn't. New York: McGraw-Hill, c2002.

Gillespie, O. N., "Buy New Zealand Goods - and Build New Zealand" - The New Zealand Railways Magazine, Volume 14, Issue 10 (January 1, 1940): New Zealand Government Railways Department. Wellington. 15.08.11. <http://www. nzetc.org/tm/scholarly/tei-Gov14_10Rail-t1-body-d6.html>

Gledhill, Sean., Aurecon - Building Structures Service Leader. interview, 29 August 2011

Gow, Lindsay., Curbing the Sprawl: Urban Growth Management in the United States - Lessons for New Zealand: Wellington, N.Z.: Ministry for the Environment, 2000

Gray, Christopher., Streetscapes: 80 Wooster Street; the Irascible 'Father' of Soho. 27 March. $2011<$ http://www. nytimes.com/1992/03/15/realestate/streetscapes-80-wooster-street-the-irascible-father-of-soho. html?scp=6\&sq=warehouse $\% 20$ living\%20\%20soho\&st=cse $>$.

Gray, John. Message to the author. Hannah Warehouse Questions.7 September 2011. Email

Gray, John. Personal Interview. 2 September 2011

Green, Suzanne., "Historic Building gets a lived-in look." The Evening Post. July 172001

Green, Suzanne., 'Historic woolstore rebuilt'. The National Business Review. 27 Sep 2002

Hamnett C, Whitelegg., "Loft Conversion and Gentrification in London: From Industrial to Postindustrial Land Use." Environment and Planning 39 (2007): 106-24.

Hannah Warehouse Prospectus, 13 Leeds Street Te Aro/Wellington.1999. Source Victoria Quade

Harbison, Robert. Eccentric Spaces. London: Secker \& Warburg, 1989 c1977.

Hardwick Smith John, Director, Athfield Architects. Message to the author.24.11.11. email

Historic Places Trust Archives, Waterloo on Quay Pamphlet. Wellington. Personal Visit 18 May 2011

Hodgson, Terence E. R., Colonial Capital: Wellington, 1865-1910. Auckland, N.Z.: Random Century, 1990. 
Holman, Sarah., "Finding Funds for Heritage". New Zealand Historic Places. No 68, May 1998. 26-28

Homberger, Eric. New York City: A Cultural and Literary Companion. New York: Interlink Books, 2003.

Hudson, James R. The Unanticipated City: Loft Conversions in Lower Manhattan. University of Massachusetts Press, 1987.

Jackson, Peter. "Neighbourhood Change in New York: The Loft Conversion Process." Tijdschrift voor economische en sociale geografie, Vol 76, Issue 3. Wiley Online Library. Victoria University of Wellington Library. Wellington (NZ) 4 April 2011.

Jäger, Frank Peter., Old \& New: Design Manual for Revitalizing Existing Buildings.Basel: Birkhäuser. c2010.

Kelly, Michael., Odlin's Building Statement of Significance for Wellington City Council. Wellington City Council Heritage Inventory. New Zealand Historic Places Trust. 1995

Kostelanetz, Richard., Soho: The Rise and Fall of an Artist's Colony New York: Routledge, 2003.

Kryton The Worlds Only Permanent Concrete Waterproofing Solution, Odlin's Building Wellington Waterfront.New Zealand 1 August. $2011<$ http://www.kryton.com/_webapp_64915/Odlins_Building?A=SearchResult\&SearchID=2587887\& ObjectID=64915\&ObjectType=35>

Lorente Pedro, J., Art Neighbourhoods, The city's beating Art-Locality, Regeneration \& Divers[cities]. Ed. Bennett, S. Butler, John: Intellect, 2000.

Louis E. Ward., Early Wellington-Reclamations. Whitcombe and Tombs Limited, 1928, Auckland. 12.07.2011. <http://www. nzetc.org/tm/scholarly/tei-WarEarl-t1-body-d21-d24.html>

Mathew Arcus and Kel Sanderson., The Rejuvenation of the Hannahs Block: An assessment of the impact of the what's new limited developments on Wellington city. April 2004. 6. 5 Oct 2011. <http://www.thewellingtoncompany.co.nz/images/rejuvenation_hannahs.pdf>

Matthew Wright and Megan Cook. Freight and warehousing, Te Ara - the Encyclopedia of New Zealand, 5 July 2011. $<$ http://www.TeAra.govt.nz/en/freight-and-warehousing/5/2>

McClean, Robert. "Internal Memo", New Zealand Historic Places Trust, 12 August 2002

McGuiness, Mark, "Deal Struck to restore waterfront building." The Dominion, 11 April 2002. 12

McIntyre, Roberta, The Making of Wellington 1800-1914. Ed. Nicholls, David Hamer and Roberta. Wellington: Wellington [N.Z : Victoria University Press, 1990.

McKay, Brett Principal Planner Strategy, Planning \& Urban Design. Wellington City Council. Industrial to residential zoning amendment. Message to the author. 3.5.11. Email

McLean, Gavin, Odlins Building 11 Cable Street, Wellington, New Zealand Historic Places Trust. 30 Oct $1997 . .6$ August 2011. <http://www.historic.org.nz/TheRegister/RegisterSearch/RegisterResults.aspx?RID=7418>

Moran, Paul, "Shed 21 on Track to Become Apartments". The Dominion . 2000.

Murphy, Lyn., "Waterfront Plans all at sea over Odlin's lease”. The Evening Post. 7 June 1994

New Zealand Historic Places Trust, Earthquake Risk Buildings-Recommendations and Guidelines for classifying, Interim Security and Strengthening, 3 March 2009,p26. 3 October 2011. <http://www.historic.org.nz/en/ProtectingOurHeritage/ /media/Corporate/Files/Submissions\%20and\%20research/DraftGuideEarthquakeStrengthening.ashx>

New Zealand Historic Places Trust. Earthquake Strengthening Improving the Structural Performance of Heritage Buildings. 13 Aug 2010. 14 June 2011 <http://www.historic.org.nz/ProtectingOurHeritage/ /media/Corporate/Files/Submissions\%20and\%20research/DraftGuideEarthquakeStrengthening.ashx>

New Zealand Historic Place Trust. Historic Place Assessment Under Section 23 Criteria. New Zealand Historic Places Trust. Wellington, NZ. 2002 
New Zealand Historic Places Trust. Robert Hannah and His Family. 15 Mar 2011. <http://www.historicplaces.org.nz/placestovisit/lowernorthisland/antrimhouse/history.aspx>

New Zealand Historic Places Trust. Wellington Harbour Board Shed 21 'Waterloo Quay, Wellington'. 8 May 2011. <http:// www.historic.org.nz/TheRegister/RegisterSearch/RegisterResults.aspx?RID=237>.

Niesewand, Nonie. Converted Spaces. London: Conran Octopus, 1998.

"Nine chase Odlin's building demolition." The Evening Post, 23 July 1991. Wayne Shephard Archive of Wellington. Archives New Zealand.

"NZIA Resene Branch Awards. Hannah Factory Apartments. Wellington. Athfield Architects: Ian Athfield." Architecture New Zealand. Jan/Feb 2000. 19

"Odlin's Building decision delayed", The Evening Post. 6 August 1991. Wayne Shephard Archive of Wellington. Archives New Zealand.

Odlin Timber and Hardware Co. 11-21 Cable Street, shop and store. 8 Aug 1964. Plan and Specification. 00058 335_ C14409. Wellington City Council Archives, Wellington

Penty and Blake. 13 Leeds Street, factory. 21 Jan 1908. Building Permit/Consent. 00053_143_7933. Wellington City Council Archives. Wellington. 1 September 2011. CD

Philip S. Morrison, Scott McMurray. "The Inner-City Apartment Versus the Suburb: Housing Sub-Markets in a New Zealand City", Urban Studies, Vol. 36, No. 2, 377-397, (1999). 12 July. 2011. <http://usj.sagepub.com/content/36/2/377. full.pdf,>.

Pragnell, Hubert J. Industrial Britain: An Architectural History. London : Ellipsis, 2000.

Quade, Victoria. Personal Interview. 29 September 2011.

Resintek, 11 January 2012. <http://www.resintekservices.co.uk/index.htm>.

Re-Using Redundant Buildings / Prepared for the Department of the Environment by Urbed (Urban and Economic Development) Ltd. London: H.M.S.O.1987.

Rogers, Ian. "A Waterfront Heritage." Historic Places (1994): 45, 46.

Rybczynski, Witold. Home: A Short History of an Idea. New York, N.Y, U.S.A.: Viking.1986.

Rypkema, Donovan, "The Economics of Historic Preservation." Alexandria Historic Preservation Conference and Town Meeting. May 52007.

Sarah Bennett and John (John H.) Butler. Advances in Art and Urban Futures Volume 1, Locality, Regeneration and Diverse Cities. Bristol: Intellect, 2000.

Scott, Fred. On Altering Architecture. London: New York. Routledge. 2008..

Shaw, Bob. "Building saved by boom". Evening Post. 4 June 1996. 13

Simmons, Rhodd. Planning Technician Local Area Planning Team Development, Planning \& Compliance. Wellington City Council. Message to the author. Carparks per Inner City Apartment Research question. 16 Nov 2011. Email.

Slesin, Suzanne, et al., The Book of Lofts. London: Thames and Hudson, 1986.

Soho Lofts: Apartments in New York City. 15 Oct 2011. <http://www.soho-lofts.com/>.

Stefan Breitling and Johannes Cramer, Architecture and the Existing Fabric. Berlin: Basel: Birkhäuser: London: Springer. 2007.

Stuart, Niven."If the Shoe Fits". Architecture New Zealand November/December 1989. 
Stylish City Apartment 28 Waterloo Quay Wellington Central. 24 February 2011. 15 May 2011. <http://www.realestate. co.nz/1502589>.

Thornton, A.W. Twenty-Five Years of Strengthening Wellington. 2010 NZSEE Conference, Wellington, 2010. Web. 14 June 2011. <http://db.nzsee.org.nz/2010/Paper26.pdf>

Tolerton, Jane. Clothing and footwear manufacturing - Māori and colonial clothing, Te Ara - the Encyclopaedia of New Zealand, updated 26-Nov- 10. 17.8.11. <http://www.TeAra.govt.nz/en/clothing-and-footwear-manufacturing/1>

Tolliver, Jessica. Loft Style. Friedman /Fairfax, 2002.

Tony Wilson, Michael Kelly. Wellington City Council. Maritime Heritage Trail. 8 April 2011. <http://www.wellington.govt.nz/ services/heritage/pdfs/maritimetrail.pdf>

"Trendy Apartments going to wealthy middle-aged", Historic Places Trust. Wellington. visit 18 May 2011.

Wagstaff, Blyss. Heritage Advisor-Registration, New Zealand Historic Places Trust "Hannahs Factory question". Message to the author.17.11.11. email

Wale, Annette. Apartment 2.0, Waterloo on Quay Apartments resident. Message to the author 23.11.11. email

Wale, Annette. Apartment 2.0, Waterloo on Quay Apartments resident, Personal Interview., 5.5.11

"warehouse, n.". OED Online. December 2011. Oxford University Press. 15 January 2012 <http://www.oed.com/view/Entry/ 225704? rskey=V2HIUF\&result $=1>$.

Wellington City Council. Chapter 12 Wellington Central. 10 July 2009. Web. 4 May 2011.

Wellington City Council. Explore Wellington. 14 Aug 2011. <http://www.wellington.govt.nz/services/heritage/pdfs/waterfront.

$$
\underline{\mathrm{pdf}}>
$$

Wellington City Council. Heritage Grants. 9 February 2011.15 June 2011 <http://www.wellington.govt.nz/haveyoursay/meet ings/committee/Strategy_and_Policy/2011/09Feb0915/pdf/Report_4_-_Heritage.pdf>

Wellington City Council. Proposed District Plan Change 73 'Suburban Centre Review-Centre'. Wellington City District Plan. 29 Sept 2009. 3 May 2011. <http://www.wellington.govt.nz/plans/district/planchanges/pdfs/change73/change73decision-report.pdf>

Wellington City Council. Suburban Centres Review. Wellington. 3 May 2011. <http://www.wellington.govt.nz/projects/ongoing/suburban.html>

Wellington City Council. Stock Exchange. Web. 12 August 2011. <http://www.wellington.govt.nz/projects/ongoing/stockex change.html>

Wellington City Council., Wellington City District Plan. Wellington, N.Z. Sep 2009. 4 May 2011. <http://www.wellington.govt. $\mathrm{nz} /$ plans/district/planchanges/pdfs/change73/change73-s32report.pdf>

Wellington Waterfront. "Deal Confirmed For Odlin's Building". 10 April 2002. <http://www.wellingtonwaterfront.co.nz/me dia_section/news_releases/news_release_archive/odlins_building.htm $>$

Wellington Waterfront Framework. Heritage on the Waterfront. Wellington. 19 May 2011. <http://www.wellingtonwater front.co.nz/history/heritage_on_the_waterfront/>

Wellington (N.Z.).Waterfront Leadership Group. Wellington (N.Z.).City Council. The Wellington Waterfront Framework / Report of the Waterfront Leadership Group. Wellington, N.Z.: Wellington City Council, 2001. Print.

Willis Bond \& Co. Web. 11.7.11. <http://www.willisbond.co.nz/>

Winter, John. Industrial Architecture: A Survey of Factory Building. London: Studio Vista, 1970.

Wright, Richard. "Appraisal” Architecture New Zealand November/December 1989. 39 
Zukin, Sharon. Loft Living: Culture and Capital in Urban Change. London : Radius, 1988.

Zukin, Sharon. Naked City:The Death and Life of Authentic Urban Places. Oxford; New York: Oxford University Press, 2010. 


\section{Eigures}

All images unless stated and referenced were taken by the author.

Fig 1. "Former Hannah Factory converted into Hannah Factory Apartments in 1994, 14 Leeds Street, Te Aro, Wellington." Source: Athfield Architetcs. CD

Fig 2. "Research Phases and key themes"

Fig 3. Source: Hudson. R, James, "Lower Manhattan: SoHo and Adjacent Neighborhoods." The Unanticipated City-Loft Conversions in Lower Manhattan.20.

Fig 4. Source: Williams, Jeniffer, "Haughwout Building, Williams. J. example of a cast iron adorned building.", Photography Exhibits Document New York City Landmarks, Neighborhoods .retrieved from. http://antiquesandthearts.com/Antiques/TradeTalk/2009-04-14 10-10-10.html

Fig 5. Source: flickr. "Lord Taylor Building, another example of a former retail building" retrieved from, http://www.flickr. com/photos/wallyg/655248787/

Fig 6. "Loft Building in New York. Characteristics: open plan space, largely unaltered internally, large scale windows and exposed structural elements.." Source: Marcus Field, Lofts USA: Gingko Press, 1999: 42,43.

Fig 7. Early signs of residential inhabitation seen through garbage bags left outside. Source: Slesin, Suzanne, et al., The Book of Lofts. Londo : Thames and Hudson, 1986: 25.

Fig 7b. "Legal vs. illegal conversion", Jackson, Peter. "Neighbourhood Change in New York: The Loft Conversion Process." Tijdschrift voor economische en sociale geografie, Vol 76, Issue 3. Wiley Online Library. Victoria University Of Wellington Library. Wellington (NZ) Web. 4 April 2011.

Fig 8. "Land use zoning measures in Lower Manhattan ". Source: Lofts: balancing the qualities. New York City Planning Commission, April 1981

Fig 8b. "Pioneering artists used the space for work and living, with minimum intervention to the space." Source: Fairbridge C. Kingsley, Harvey-Jane Kowal, Loft Living, Saturday Review Press, 1976 83, 126

Fig 9. "Double height spaces and free standing island style kitchen are common in converted warehouses/lofts." Source: Slesin, Suzanne, et al., The Book of Lofts. London: Thames and Hudson, 1986: 160.

Fig 10. "Axonometric Plan showing mezzanine level with bedrooms overlooking the main living area." Source: Slesin, Suzanne, et al., The Book of Lofts. London: Thames and Hudson, 1986: 240.

Fig 11. "Mezzanine level looking down onto the living area." Source: Slesin, Suzanne, et al., The Book of Lofts. London: Thames and Hudson, 1986: 158,159.

Fig 12. 'Working and living space". Source: Slesin, Suzanne, et al., The Book of Lofts. Londo : Thames and Hudson, $1986: 91$. Fig 13. "Bare floors, exposed ceiling, exposed columns, double height space, large full height windows, absence of partition walls, standard features in a converted warehouse space". Source: Slesin, Suzanne, et al., The Book of Lofts. London: Thames and Hudson, 1986: 124.

Fig 15. "Abundance of light, in a loft space", Source: Slesin, Suzanne, et al., The Book of Lofts. London: Thames and Hudson, 1986: 82

Fig 16. "White washed brick and the absence of covered storage. This approach of displaying objects out in the open was common in early loft examples.", Source: Slesin, Suzanne, et al., The Book of Lofts. London: Thames and Hudson, $1986: 83$. Figs 17+18+19. Modern conversion in New York displaying sleek modern finishes and fixings. Source: http://www.apartmentmodern.com/

Fig 18. Source: http://www.apartmentmodern.com/

Fig 19. "Modern Conversion" Source: http://www.apartmentmodern.com/

Fig 20. "Location of warehouses analysed in this thesis. Year of original construction and conversion."

Fig 21. "Wellington Container port." Source: Te Ara Encyclopaedia of New Zealand. http://www.teara.govt.nz/en/freightand-warehousing $/ 5 / 2$

Fig 21b. "Reclamation Taranaki Street Wharf, C \& A Odlin Timber and Hardware Co Ltd in background, 20 June 1971. Its location means the building is subject to liquefaction and is also why the building suffered so much damage due to the water penetration in its basement area." Source: the Fletcher trust Archive. Series \#: 6259P Item \#:6259P/134. Web access. http://www.fclarchives.co.nz/item.php?id=28966. 7.02.12

Fig 22. "Wool Store circa 1911". Source: Wellington City Council Archives, Wellington. Record No: 219 
Fig 23. "Waterloo on Quay Apartments, 2011".

Fig 24. "Shed 21, historic events"

Fig 25. "Marshall Field Warehouse. Similar architectural rhythms can be seen." Source: http://en.wikipedia.org/wiki/ File:Marshall Field Warehouse Store.jpg date accessed: 23.5 .11

Fig 26. "Northern view of Wharves and Shipping with Shed 21 visible in the background. Sep 1919". Source: Wellington City Council Archives, Wellington. Record No: 316

Fig 27. "Unloading of cargo". Source: Wellington City Council Archives, Wellington. Record No: 230

Fig 28. "Lower Floor at Shed 21, full of cargo." Source: Wellington City Council Archives, Wellington. Record No: 211

Fig 29. "Circa 1911. Gallery level at Shed 21. The glass roof was reused to give an extra source of light upon conversion into apartments. The otherwise dark hallway area between the two sides of apartments benefitted from this light projecting downwards." Source: Wellington City Archives. Record No:214

Fig 30. "Time of conversion. Accumulator Tower looking up. Upon conversion the stairs on the North side were built around this feature. The existing steel and timber beams running vertically up the Accumulator wall were also retained." Source: Athfield Architects Archives.

Fig 31. "Foundation Plan showing woolpress pit (central), culvert on the seaward side, cart dock on the right side, accumulator tower on the left and railway track on the street side". Source: Wellington City Council Archives, Wellington. Record No: AC016:3:158, 1910

Fig 32. "During the building's dereliction phase it was partly used as a carpark". Source: Athfield Architects Archives

Fig 33. "Original sliding doors were repaired and reused"

Fig 34. "Apartment 2.0 Layout (upper level)" Source: Drawing property of Annette Wale, Apartment 2.0, Waterloo on Quay Apartments resident

Fig 35. "Mezzanine level overlooking lower level". Source: Athfield Archives

Fig 36. "Interior of Apartment 2.0. This was the largest apartment in the building and had the most unique configuration being situated on the corner. Apartment 3.1 was one level above, however it was much smaller. Double height spaces allowed for the bedrooms to be inserted in a mezzanine level overlooking the living area. The conversion is a combination of preserving the buildings main character yet still containing modern finishes and having a sense of "home". This is visible through the carpeted areas throughout the apartment, popular kitchen and bathroom materials. The owners of this apartment had flexibility in the final design of their apartment, including demolishing part of the wall on the ground level to make a larger space that it was initially designed as.".

Fig 37. "Shutters are used to close off the space for privacy and against light". Source: Athfield Architects

Fig 38. "Analysed diagrams showing changes to building upon conversion".

Fig 39. "Linear apartment layout reflecting existing structural grid." Source: Wellington City Council Archives, Wellington. Record No: 00078:1019:82325

Fig 40.“Communal areas". Source: Athfield Architects

Fig 40b. "Seaward facing exterior". Source: flickr. Web access. 1.02.12, www.flickr.com/photos/bness/5602802206/

Fig 41. "Shed 21 during the 1913 waterfront strike. West face is still closed off." Source: Photograph taken by S C Smith. Brady Dyer Photography. http://www.bradydyer.com/canvas-shop/wellington-canvas/special-constables-on-waterloo-quayduring-the-1913-waterfront-strike/

Fig 42. "Converted Shed 21, currently Waterloo on Quay Apartments. Walkway established in the West facade." Source: http://www.flickr.com/photos/russellstreet/4643816377/

Fig 43. "1950" Source: Alexander Turnbull Library Reference Number: 114/150/08-F, http://mp.natlib.govt.nz/detail/?id=52 021\&recordNum $=8 \& \mathrm{t}=$ items\& $\mathrm{q}=$ odlins\& $\mathrm{s}=\mathrm{a} \& \mathrm{l}=\mathrm{en}$

Fig 44. "Odlins in 1953". Source: Alexander Turnbull Library reference Number: PAColl-6407-44, http://mp.natlib.govt.nz/de tail/?id=24022\&recordNum=20\&t=items\&q=odlins\&s=a\&l=en

Fig 45. "Odlins as a factory, warehouse and store." Source: National Library of New Zealand Ref: 1/2-209969-F, http://beta. natlib.govt.nz/records/23212464

Fig 46. “Fig 46 Odlin's Building 1957-2004. Changes are visible both to the buildings surrounding context and the building itself. Note the changes in land reclamation and the deterioration of the buildings exterior. Source: National Library of New Zealand

Fig 47. "The building was severely damaged, largely due to water rot."

Fig 48. "Seaward side exterior facade underwent extreme alteration." Source: Wellington City Archives Ref No: 00078:1389:106500 
Fig 49. "Timber in the ceiling was reused as formwork for the new concrete floors." Thornton, Adam Seimic Strengthening and refurbishment of heritage Buildings. 45. http://www.ipenz.org.nz/heritage/Conference2004/Presentations/Thornton,\%20 Adam\%20-\%20Seismic\%20Strengthening.pdf

Fig 50." Digital model showing structural changes."

Fig 51. "Structural methods".

Fig 52. "The image above was a drawing done by Dunning Thornton illustrating the Polystyrene filler that was inserted around the perimeter of the buildings shell, between the existing brick wall and the new concrete."Source: Dunning Thorndon Engineers. Drawing Number S32. 11 Sep 2003. CD Plans

Fig 52.b "Apartment layout showing lower level. Apartment 4F, circled." Source: Wellington City Archives Ref No: 00078:1389:106500

Fig 53. "Existing timber floor joists were reused in the ceilings and in communal areas as wall features."

Fig 54. "Apartment 4 F. Primary existing material retention visible in the timber ceiling joists." Fig 55. "Hannah Block, highlighting the Hannah Factory". Source: Stuart, Niven, "If the Shoe Fits”. Architecture New Zealand November/December 1989. Fig 56. "Hannah Factory staff, 1930s" Source: Te Ara Encyclopaedia of New Zealand. Alexander Turnbull Library Reference: PA6-661 http://www.teara.govt.nz/en/population-change/5/2

Fig 57. New Zealand Railways Magazine, Vol 14, issue 10, Jan 1940. http://www.nzetc.org/tm/scholarly/teiGov14 10Rail-t1-body-d6.html

Fig 58. Existing South Elevation. Source: Wellington City Archives 14-16 Leeds Street, factory Ref No: 00055:7: A649 Fig 59. "Conversion into apartments allowed for an opening through the building, creating access from Leeds Street to Ghuznee Street."

Fig 60. "Prior to conversion, circa 1992." Alexander Turnbull Library Pictures. Evening Post Collection of Photos, WELLINGTON, FOOTWEAR/INDUSTRY. 1894

Fig 61. "Showing the dramatic increase in price of the apartments from 1991-2001, (BERL What's New Ltd report)." Source: Mathew Arcus and Kel Sanderson. The Rejuvenation of the Hannahs Block: An assessment of the impact of the what's new limited developments on Wellington city. April 2004. 6. 5 Oct 2011. <http://www.thewellingtoncompany.co.nz/images/rejuvenation_hannahs.pdf>

Fig 62. "New access way from Ghuznee to Dixon was created by opening up the ground level."

Fig 63. "Plan showing the thoroughfare created upon conversion of the factory." Source: Wellington City Archives. Athfield Architects Ltd. Ref no: 00078:668:42005

Fig 64. "Digital model showing structural upgrade. Shear walls and cross braced new concrete floors."

Fig 65. "Industrial aesthetic visible throughout the building: old elevator reused."

Fig 65b. "This section illustrates the application of the fyreline to the underside of some of the floors and the walls." Source: Athfield Architects. Job Number. 95-81.Drawing Number A4. 19.9.1996.

Fig 66. "Digital render showing new concrete floors in dark red and the shear walls."

Fig 67. "New structural walls highlighted in red." Source: Wellington City Archives. Athfield Architects Ltd. Ref no: 00078:668:42005

Fig 68. "Digital render showing new insertion of steel cross bracing to the underside of floors as well as bond beams." Fig 69. "Industrial elements were used in the kitchen joinery and fittings. Piping and wiring was left exposed."

Fig 70. "Apartment 2 Interior."

Fig 71. "Smaller apartment 2 highlighted. The apartment spanned two levels" Source: Wellington City Archives. Athfield Architects Ltd. Ref no: 00078:668:42005

Fig 72. "Above, one of the largest apartments in the factory. Drastic changes appear to have been made to the original scheme and aesthetic of the earlier apartments and specification by Athfield Architects. Including painting the exposed timber in the ceiling, white washing of the brick, staining the existing timber floor a darker hue, insertion of a glass balcony on the mezzanine level and new kitchen fittings." Source: Wellington property for sale. ID \#235354 8.10.11. http://www. wellingtonpropertyforsale.co.nz/property.php?id=235354\&n=5\&o=50\&t=\&rnd=1

Fig 73. "Location of Hannah Warehouse within the Hannah Block." Source: Stuart, Niven."If the Shoe Fits". Architecture New Zealand November/December 1989.

Fig 74. "Fig 74. Hannah Warehouse Prospectus, featuring the Hannah Warehouse. The Hannah Factory is directly adjacent on the right." Hannah Warehouse prospectus. Source: Victoria Quade

Fig 75. "Early conversion stages". Source: photos courtesy of John Gray

Fig 76. "Largest Four apartments that were the originally owned by the investors are highlighted in red. The smaller apart- 
ment highlighted blue is referenced in Fig 77. All highlighted apartments spanned three levels." Hannah Warehouse Prospectus. Source: Victoria Quade

Fig 76.b. "Attic level, showing the size of the largest 4 apartments. This is the top level where the bedroom in Unit 2 was situated as of 2011." Source: Victoria Quade

Fig 77. "Interior of smaller apartments within the Hannah Warehouse." Source: Top three images Wellington Property for Sale.

2.1.11, http://www.wellingtonpropertyforsale.co.nz/property.php?id=159818.

Fig 78. "Fig 78. Layout sketch by John Gray of his former apartment-living area level. The bedroom was initially positioned on the same level as the dining space, before being relocated to the Attic level.." Source: John Gray

Fig 79. "Fig 79. Apartment interior, 2011. The current owner is a professional, single middle aged male."

Fig 80. "Apartment interior, 2011. Bedroom with open bath area top right. Elevator opening at living area bottom image."

Fig 81. "Interior showing traces of heritage and exposed and untouched surfaces and elements."

Fig 82. "Cross bracing to underside of floors." Source: Dunning Thornton Consultants Ltd. Structural Drawings. CD

Fig 83. "Cross bracing to underside of floors." Source: Photos courtesy of John Gray

Fig 84. "Structural upgrade of existing brick wall visible, in the form of the red disks. Because the external walls are essentially brick without a concrete frame or being set in bond and acting purely as a external cladding, the building is not very secure structurally and more earthquake prone than the Hannah warehouse."

Fig 85. "Exposed structural elements in Shed 21 apartments."

Fig 86. "White paint applied to ceilings, seen in three of the four case studies. Note the ceiling joists are left exposed, this as prevalent in all four case studies to some degree. Refer to Odlin's Building where part of the ceiling was covered up with down lights inserted."

Fig 87. "White paint applied to existing ceiling." Source: Athfield Architects CD.

Fig 88. "Shed 21 prior to conversion, circa 2000." Source: Athfield Architects Archives. 


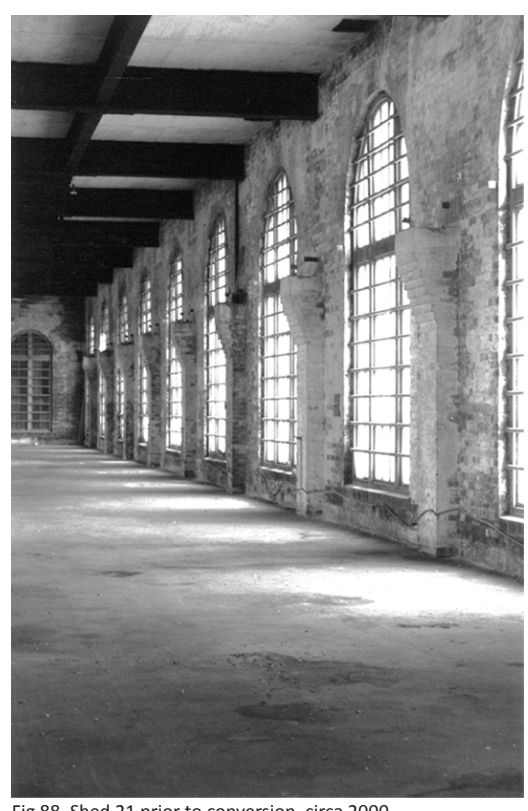

Fig 88. Shed 21 prior to conversion, circa 2000 